Historic, Archive Document

Do not assume content reflects current scientific knowledge, policies, or practices. 



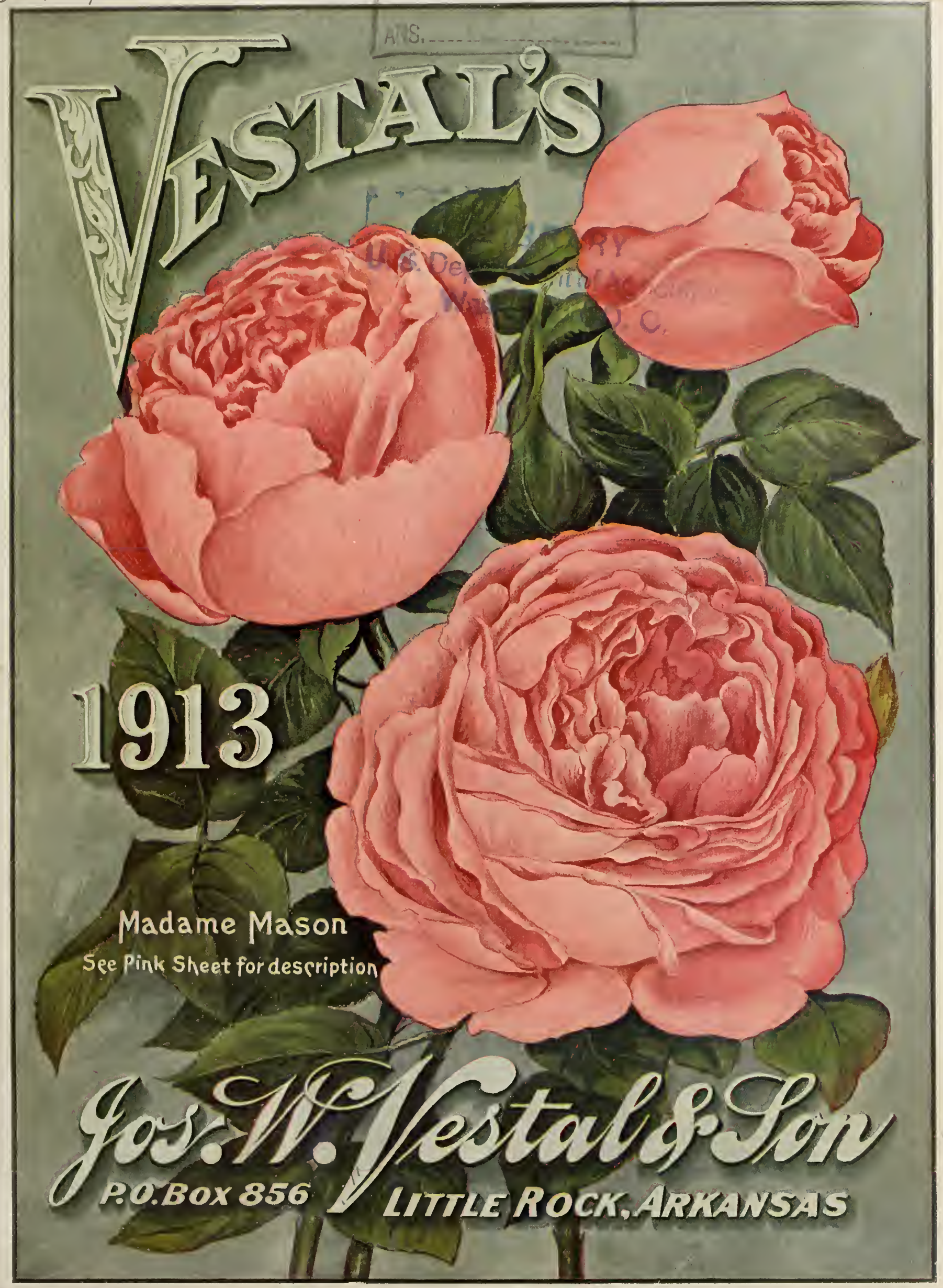




\section{VESTAL'S FAMOUS ROSES}

Famous in their superb coluring. lienutiful in bud and uaturo bloom. Reluarkable in thelr generous blooming 4unlies they are tried and tested varieties and should give general satisfaction.

l3esutiful us are the linndreds of Rose's at present in cultivation as ideal varieties for any purpose, our differen collections of Vestal's tamous lioses shown on the colored cover of this catalogue are the most wonderful. The varletle of lioses tre now so numerous and the liabits and colors so varied that we feel sure our customers will appreciate thesu collections-each and wery one of which we recommend. These wonderful Roses represent the efforts of the greatest Rosarians of the world anl are the results of many years work in liybridizing to give the umateur Rosu irower uncxelled varietics of Roses for gurden culture that possess in a high degree all the good qualities of Ever bloouing Roses. These colored plate loses in size, iurm, shape, color and freedom of blooming are unexcelled. 'They are wervetual blconing habits, uspiul and sinitable for massing, bedding and garden decoration.

\section{A Magnificent MADAME MASON}

The Queen of All Perpetual Roses

(Shown on the colored cover of this Catalogue.)

It is not given to every liose to possess qualities of greatness, and in promisiug this beutiful loose to le vne of the world's greatest varieties, we do so without the iear of contradiction. It will compsre from every standpoint of us. fulness witl sucl true and tried favorites of its color as American Beauty, Paul Neyron, General Jacqueninot, Ulrici Brunner, etc. Our experience leads us to believe that from the standpoint of the amateur Rose grower it will super "ede these varieties. It possesses every desirable feature we know of, great vigor of growth, hardiness and freedon
of bloom. These are features not possessed by all lied Roses and this feature alone will not be overlooked lis lise care of bloom. The ful Rose buyer.

It makes a fine upright bush, has but few thorns, and beautiful, deep bronze-green foliage. It is as free flowering as any Rose, bearing its massive, large fall, cup formed flowers singly, ou long, stiff stems; the color is new, clear red or crinson, brightening in the center; the flowers are of the most splendid substance and exquisitely fragrant. Again wi. bld, or new. Price, one year old plants, 20 cents each; two year old plants, 50 cents each.

FREE OFFER. If you will send us an order amounting to one dollar, from a friend or neighbor WHO is NOT NOW A CUSTOMER of ours, we will send you one of these splendid roses FREE.

\section{Vestal's Sextet of Famous Roses}

(See back cover of Catalogue.)

Our illustratiou on cover was drawn by one of the best nature artists in this country, and represents these beauti ful Roses ss near as the artist's skill can make them.

No. 1. LADY URSULA. Color a most beautiful shade of flesh pink, of great substance and yood forni; petals large, circular and delicately perfumed. A grand grower, produce, one year old plants, 15 cents each; two yeas old plants, 40 cents each.

No. 2. SUNBURST. This msgnificent gisnt yellow lose stands head and shoulder above all others of its color. it has long pointed buds. The color is orange copper or golden orange and golden yellow; edge of petals lighter: all intense shades extremely brilliant in effect. Belongs in all intense shades extremely brilliant in effect. Belongs in the class of big Roses; has created a sensation wherever
shown. Price, one year old plants, 20 cents each; two shown. Price, one year old

No. 3. PRINCE E. C. D'ARENBERG. Brilliant fier'y searlet with buds unusually good substance; a fine erect grower, with ample foliage. Price, one year old plants, 15 cents each; two year old plants, 40 cents each.

No. 4. HELENE WATTINE. White with lemon yellow center, very double and of the largest size, opening as flat as a plate, a vigorous grower and a very promising

bedder. Has the beautiful form of Malmaison. Price, one year old plants, 15 cents each, two year old plants, 40 cents each.

No. 5. PINK BEAUTY. It is without question the most remarkable of all pink Roses. It has a shining, intense deep pink color possessed by no other rose. It is a fine grower, free bloomer, good size and form, iragrant and in a class by itself as to color. It has an extraordinary deep long, very pointed flower, probable the most perfect shaped and most graceful form of any Rose grown; has no equal and most graceful form of any Rose grown; has no equal "'EVERYBODYS' ROSE." Price, one year old plants, is cents each; two year old plants, 40 cents each.

No. 6. LADY ALICE STANLEY. This, we predict. will become vcry popular as a garden Rose. The petals are shell shaped, forming a perfect Hower; the color on outside of petals is a deep coral rose; inside delicate flesls. fushed and suffused with bright yellow. Remarkable, at
tractive without doubt. A magnificent Rose. Price, one year old plants, 20 cents each; two year old plants, 50 cents each.

We will supply one each of the Vestal's Sextet of Famous Roses in one year old plants for 75 cents; one each of these fine Roses in two year old plants for $\$ 2.00$; or they can be purchased separately at prices attached.

\section{VESTAL'S "LEADING FIVE" OF FAMOUS EVERBLOOMING ROSES}

(Shown on inside front cover page.)

No. 1. MRS. DAVID JARDINE. It is not given to muny Roses to possess the two valuable characteristics such as Mrs. Jardine does in being one of the greatest pink hybrid Tea Roses for forcing under glass, as well as a garden bush Rose of the first watcr. The blooms are large, of perfect form and produced on every shoot; very highly verfumed; color a delightful shade of bright, rosy pink slading on the outer petals to saimon-pink. Price, 20 cents each; two year old plants, 50 cents each.

No. 2. ROSEMARY. A beautiful Rose of shining, silvery pink recommended for bedding. Very large and very double; a sturdy grower with stiff stems and large foliage; lowers freely produced. Price, 20 cents each; two year old plants, 50 cents each.

No. 3. MELODY. A most charming and decidedly beautiful rose, which attracted the attention of all visitor to our Rose gardens during the past summer because of its marvelons free blooming qualities. The blooms are of good size; the color is an inteuse, pure deep saffros yellow, with primrose edges, a delightiul color harmouy. 15 cents each; two year old plants, 40 cents each.

No. 4. PRINCESS CHARMTNG. A quick, free, healthy grower; blooms early, and throughout season gives un. large, finely formed, free and double. A lovely combina. tion of deep rose and yellow shades. Price, 15 cents each; large two year old plants, 40 cents each.

No. 5. ETOILE DE FRANCE. It is a strong, healthy grower, quite hardy, and a quick and abundant bloomer; makes beautiful large pointed buds and extra large fully double fowers three and one-half to four and one-half inches across: color very bright, dark rich crimson; ex. inches across; color very bright, dark rich crimson; tx. the finest roses in cultivation. Price, one jear old plants. 15 cents each; two year old plants, 35 cents each.

We will supply one each of the Leading Five of Vestal's Famous Roses in one year old plants for 60 cents; one each of these fine Roses in two year old plants for $\$ 1.50$; or they can be purchased separately at prices attached. 


\section{The Eight Best Garden Roses}

(Shown on back inside cover page.)

\begin{abstract}
The eight rarieties listed below have been offered under this lieading with a view of supplying the an:atenr, who is not familiar with the various varieties, and to whom a selection from the long list must mecessarily prove confusing as ollection which combines as varied a range of color as can be brought together in such a number of plants, with freedom of

No. 1. ALICE ROOSEVELT. A rare and very beauti. ful Rose of novel and distinct color, rich pink or rose flushed with orange and fawn. Flowers large, well fille. and very fragrant. A strong healthy grower and frec bloomer: quite hardy and fine for the growe and frec Price, 15 cents each; two year old plants, 35 cents each.

No. 2. JESSIE. The showiest and prettiest of the "Baby" Roses; this charming and dainty little variety is of beautifully rounded habit and is a luge bouquet of brilliant bloow, deep crimson florets not crowded, but of beautiful arrangement. The color is irresistible, the plan' grows like a weed, and the flowers are nearly "immortelle" in their lasting quality. Price, one year old plants,?? cents each; two year old plants, ?? cents each.

No. 3. ANTOINE RIVOIRE. A handsome new Rose of vigorous habit of growth, with large, full, Canellia shaped flowers. Color rosy flesh, on a yellow ground. shaped with a border of carmine: flowers five inches in diameter. A remarkable variety of great worth. Price, 10 cents each; two year old plants, 30 cents each.

No. 4. PRES. WM. R. SMITH. The flowers are largr, full. 4. PRES. WM. R. SMritely formed. The potels most exquisitely formed. The jotals look like wax, softy curled, colored cresin witl flesh tint tips, buff yellow base and the center a heart of pink. Perfect buds. The flowers are borne on long, strong stems, just right for naking hoquets. Price, one year old plants, 15 cents each; two year old plants, 35 cents each.

No. 5. WeLLeSLey. The flower's ite extra large and full; color bright, clear rose pink reverse of petals silve rose; a vigorous grower, bearing its fowers on tall, stif canes; very free bloomer and the fiowers are of excellent substance and durability. Price, one year old plants, 15 cents each; two year old plants, 40 cents each.

To. 6. COL. R. S. WILLIAMSON. Sintin white with deep blush center; bluoms very large, full, of perfect form, with high, pointed renter: rennes rigid and freel produced, petals round and of meat substance. I fariud Rose for any purpose. Frice, one year old plants, 15 cents; two year old plants, 35 cents each.

No. 7 GRUSS AN TEPLITZ, As a belding rose this is one of the finest. and most useful varieties pver sent out. The color is brightest searlet, sluding to deep, rich relvety crimson. It is very fragrant. The freest grower and the most profuse of any everblommo. Price, one year old plants, 10 cents each; two year old plants, 25 cents each.

No. 8. ETOILE DE LYON. This magnificent Tea Rose south of the Ohio River, las proved to be perfectly hardy. Blooms in the greatest profusion and each bud is a gem. Flowers are very large, double, full: deliciously fragrant. The color is a beautiful clarome rellow, decpening at center to pure golden yellow. Price, one year old plants, 15 cents each; two year old plants, 30 cents each.
\end{abstract}

We will supply one each of the Eight Best Garden Roses in one year old plants, for $\$ 1.00$; one each of these fine Roses in two year old plants for $\$ 2.00$; or they can be purchased separately at prices named.

\section{PARCEL POST AND EXPRESS RATES}

ON JANUARY 1ST OF THIS YEAR THE PARCEL POST LAW CAME INTO USE. BY THIS NEW I.AW WE WILL BE ABLE TO SEND BY MAIL ALL PACKAGES OF PLANTS, BULBS, SEEDS OR CUTTINGS UP TO ELEVEN POUNDS IN WEIGHT TO ALL POINTS IN THE UNITED STATES AT THE RATE OF EIGHT CENTS PER POUND, WHICH MUST BE PAID BY THE PURCHASER, EXCEPT IN CASES WHERE WE EXPRESSLY STATE WE WILL SEND PREPAID OR BY SPECIAL ARRANGEMENT. ALL SEED AND ALL ORDERS UND WILL BE SENT PREPAID

EXCEPT TO NEAR-BY POINTS IT WILL BE FOUND CHEAPER TO SEND MEDIUM TO LARGE ORDERS BY EXPRESS, AS WE ARE GIVEN $\Lambda$ SPECIAL RATE ON PLANTS AMOUNTING TO FROM 20 TO 35 PER CENT BELOW THE GENERAL MERCHANDISE RATE.

WE WILL ALWAYS USE OUR BEST JUDGMENT IN THE INTEREST OF OUR CUSTOMERS, AS TO WHETHER IT WOULD BE CHEAPER TO FORWARD THEIR ORDERS BY EXPRESS OR PARCEL POST. FURTHER THAN THIS, WE WILL UNDERTAKE TO FORWARD ANY ORDER PREPAID TO ANY POINT IN THE UNITED STATES AND GUARANTEE SAFE DELIVERY FOR THE SMALL ADDITION OF 10 CENTS TO EACH DOLLAR OF THE TOTAL AMOUNT OF YOUR ORDER.

\section{SPECIAL EXPRESS RATES FOR PLANTS}

BY SPECIAL ARRANGEMENT WITH ALL EXPRESS COMPANIES, ALL PLANTS ARE CARRIED AT A REDUCTION, AND ON ACCOUNT OF A GRADUATED SCALE OF RATES RUN FROM TWENTY PER CENT TO THIRTY-THREE AND ONE-THIRD PER CENT LESS THAN THE REGULAR IMERCHANDISE RATE. AS THIS IS THE LARGEST SHIPPING POINT FOR PLANTS IN THE SOUTHWEST, AND ALL OFFICES ARE SENDING OUT PLANTS EVERY DAY IN THE YEAR, AND THE CHARGES ARE REGULATED AT THE OFFICES HERE, YOU WILL ALWAYS RECEIVE ADVANTAGES OF THE SPECIAL REDUCTION.

\section{SPECIAL NOTICE}

IN REMITTING STAMPS FOR SMALL AMOUNTS, PLEASE SEND THE PARCEL POST STAMPS INSTEAD OF THE ORDINARY POSTAGE STAMPS. WE ACCEPT STAMPS IN AMOUNTS LESS THAN ONE DOLLAR, OR WHERE POST OFFICE MONEY ORDER CANNOT BE HAD, PROVIDED A TWO-CENT STAMP EXTRA IS SENT WITH EACH REMITTANCE. NONE BUT STAMPS IN PERFECT ORDER ACCEPTED. 


\section{CUT FLOWER DEPARTMENT}

ORDERS FOR CUT FLOWERS SHOULD BE DIRECTED TO 409 MAIN STREET, BEARING A SPECIAL DELIVERY STAMP, TO RECEIVE PROMPT ATTENTION.

Long Distanee Phone 463. After 6:30 p. m. and Sunday noon, Call 687 .

"lhis lepurtunent in our lusiness is made a specialty. With fucilities for growing u constant supply of fowers at all seasons of the yeur, we nre uble to execute orders at the sliortest notice.

is prices of Cut Flowers rary according to the season of the year and the scarcity of flowers, it is next to impossible to give any fised prices here, hut we slutll always endenror to fill orders at as low rates as we can afford at the seasoll you order.

When ordering please mention the time articles must rencls you to be available. If time does not allow to order ly: mail, telegrnph us.

If ordered by telegraph, articles will be sent C. O. D.

We canuot be responsible for delayed trains in transit.
Rush orders by mail slould lave a speciul deliver stump attached to insure prount delivery to us. When time is limited, telegrapl to us, stating time flowers must reach you, and we will give it prompt attention; but it is to your advantage to give reasonable time when possible. ill designs and flowers sent by express, the only safe way. We express safely at all seasons.

Our Cut Flowers are always on sale at our City Store No. 409 Main Street, to which place all Cut Flower orders hould be addressed.

In ordering designs, always state the amount you wish to pay, and we will always send us large and landsome pieces ins we can for the amount. If undecided what to order, we will make the selection for you.

Always give full directions. I'riecs, net cash.

\section{PARLOR FOLIAGE COLLECTION}

FOUR STRONG PLANTS FOR ONLY 50 CENTS, BY MAIL, POSTPAID

In this collection we give you a strong plant of the best of all ferns. "Whitmanii," also a plant of the new ferı Sicloeltzi, " together witl a Boston Feru and a plant of the Lace Fern, all for 50 cents, postpaid. FOUR ELEGANT WINDOW PLANTS FOR 50 CENTS.

\section{Splendid Roses for Only 50c}

\section{CAREFULLY PACKED, LABELED AND POSTPAID.}

Including the splendid new, hardy, Everblooming Rose. GENERAL McARTHUR. $\Lambda$ new brilliant scarlet hybrid Teu witl the fragrance of the Jume Rose and a true everbloomer. It sends up thick canes continuously, every ale bearing a fine bloom. The best everblooming red rose yet introduced.

Also the strong, hardy, Everblooming Rose, WHITE MAMAN CocHET. Purc white, except in rool weather, when they slow a tinge of pink. The best white everblooning.

THE OTHER SIX STRONG, HARDY, EVERBLOOMING ROSES will be selected from our regular stock of sturdy. liealthy plants. Roses that have been thoruughly tested and found to be hardy (with protection) in this climate; of goni form, eolor and in every way satisfactory. We will choose the same as we would for ourselves and make you up a nice assortment, including all the finest colors, such as red, white, pink, etc. There will be no two Roses alike, but each one will be separately labeled and all carefully packed, wrapped and guarantced to reach you in good growing condition.

THE ENTIRE 8 ONLY 50 CENTS, POSTPAID

\section{Large Flowering Chrysanthemums, 50c}

BY MAIL POSTPAID

MAGNIFICENT VARIETIES! EVERY ONE A PRIZE WINNER! GUARANTEED TO PLEASE YOU!

CAREFULLY PACKED, LABELED AND POSTPAID

"This list will include some of the best Prize Winning Varieties. The sorts that if grown properly will capture prem iums. We strongly advise rou ordering the collection and our word for it that you will be delighted with the rarietie that we send you. ALL VARIETIES DISTINCTLY LABELED.

\section{Choice Flowering Plants for 50c}

DELIVERED FREE BY MAIL. JUST THINK OF ITI

IF YOU ARE LIMITED AS TO THE AMOUNT YOU CAN SPEND FOR FLOWERS, WE BELIEVE THAT YOU CANNOT GET BETTER VALUE THAN BY PURCHASING THE FOLLOWING COLLECTION:

ROSE. (GOLDEN GATE.) Color, creimy white, tinged with gulden yellow and rlear rose.

GOLDEN WEDDING CHRYSANTHEMUM. The largest and best golden rellow variety for general use ever in troduced.

GERANIUM, (MRS. E. G. HILI.) Everyone likes (iernniums, and while you are getting them why not have the best fancy flowering sort?

CZAR HELIOTROPE. This now giant flowered sort is a dwarf rariety, with black stems and enormous panicles of dark, velvety flower.: Color is very rich and is sure to please. Wither pot rulture or bedding.

CANNA. (Gold Burbank.) Rirh, clear yellow with ine crimson spots in center of flower.

VERBENA. (Monstrosum.) A rery large dazzling scarlet; large white eyes. Very best.
AGERATUM. (Frincess Pauline.) One of the most handsome varieties cver offered.

CARNATION. (Enchantress.) A novelty of ureat mer:t, eolor deep salmon pink, very fragrant, always in bloom.

HIBISCUS GRANDIFLORA. Full round fiowers perfect shape, and of a rich, soft carmine lose, with deep erimson eye. A rich free-blooming variety.

SWORD FERN. For house culture or for window gar dening we don't know of any other variety that woul give the same satisfaction.

FUSCHIA. "Charming.' Entirely distinct from any other variety. The flowers are of an intense rich car mine.

VIOLET. (Prince of Wales.) Most fragrant variety ever introduced; always in bloom. 
BETTER

THAN EVER

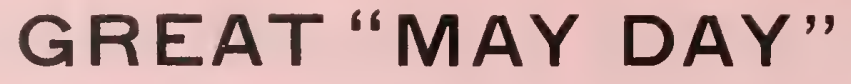

SALE

FROM MAY 10

CHOICE PLANTS AT GREATLY REDUCED PRICES

li growing so many varieties of plants in such large quantities we cannot anticipate orders and grow just what will be requived of each variety to meet the demand. We always want to make sure we have enongli of everything and conse quently we usually have a surplus of many of our choicest plants. Now, in order to close out our surplus stock at or ncar the ond of the season we have decided to offer them at grently reduced prices for thirty days after May 00 , or from 11 ay 10 to June 10. Persons ordering these colleetions will be surprised at the number and value of the plants they will contain; in fact, were wo to foot them all up at catalogue prices, you would tind you were getting them at less than lalf price. WW leselve the right to sclect varieties, but will allow purchaser to state for what purpose intended, whether for pot rnlture ar lwding: lut unless otherwise ordered, the collection will contain plants for both pot culture and hedding.

\section{"MAMMOTH" EXPRESS COLLECTION}

One Hundred Choice Plants by Express for $\$ 2.50$. Thirty-five Choice Plants for $\$ 1.00$

IVe lave named this collection "Mammoth" because it is the "biggest" colleetion ever offered for the money. It wi:l mutrin Tea lioses. Hardy Roses, Double and single Geraniums, Carnations, Chrysanthemums, Fuchsias. Begonias, Hydrall neas, etc., and many other things too numerous to mention. About half of the plants, ineluding the niost raluable ones, will be named. This collection will be packed and forwaded by express: purchaser to pay charges. This collec tion may be ordered at any time, but all orders receired prior to May 10 will be forwarded promptly on that date.

\section{Our Unrivaled Mammoth Verbenas}

For 50 cents we will send 15 strong plants in many shades, or all of one color, as many be desired.

Vext to the Germium the Verbena is the most popular and useful of bedding plants. The collection we offer 19 as fine a collection as rould be found on this continent, containing the most brilliant colors and some right fragrant rarieties, in order to keep the plants in the best blooming condition, eut all faded flowers off and eren a severe trimming or clipping tends only to strengthen the plants and keep them in better shape for late flowering. The demand we had the past season for this popular flower was simply enormous.

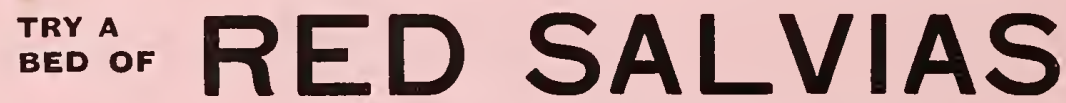

And you will have something dazzling

\section{OUR BIG 50C BULB GARDEN}

\section{Summer Blooming Bulbs for $50 \mathrm{c}$}

Twenty Splendid Summer Blooming Bulbs only 50 cents postpaid. We send first quality large Bulbs, all sure to blonı this season. These bulbs are all choice varieties and sure to grow and bloom soon after planting. All these bulbs can be rrown in pots or window boxes if desired, but most of our customers will want them outdoors. The collection eonsists of 2 New Cannas, different colors: 6 Splendid Gladiolus, different colors; 4 Double Pearl Tube Roses; 2 Lovely Cinnamon Vines; 4 New Tube Roses, "Albino," and 2 Dahlias.

Whe hope to have a sufficient number of bulbs to supply the demand. lint should it lie unexpectedly. large we reserre the right to substitute other varieties of equal value for those of which our stock may run out before the end of thr Season. BETTER ORDER EARLY.

\section{SPECIAL LOW PRICED COLLEOTION OF PLANTS}

ONLY 50 CENTS will buy any of the collections named below, delivered safely by mail, postpaid, to any addres: 'The collections are all fine, strong plants of the best varieties, and are marrels of cheapness. We can only aftord to sell them so clieaply by growing these sorts in immense numbers. The cloice of varieties must invariably be left to us. the purchaser simply naming the number of set or sets desired. There are no two varieties alike in the same collection. five this node of purcliasing plants a trial. We are confident it will please you. Order these collections hy number.

No. 1-12 Everblooming Roses, no two alike ......... $50 \mathrm{c}$

No. 2 - 8 Double Geraniums, very fine................. $50 \mathrm{c}$

No. $3-8$ Single Geraniums, choice varieties .......... $50 \mathrm{c}$

No. 4 - Double and four Single Geraniums........... 50c

No. 5-12 Scarlet Salvia ..................

No. 6- 8 scented Leaf Geraniums

No. $7-15$ Chrysanthemums, prize winners

No. $8-8$ Carnation Pinks, sweet scented

No. $9-15$ Gorgeous Coleus.

No. 10-10 Tuberoses, Double and Single.

No. $11-15$ Gladiolus, Orchid Flowering

No, 12 - 6 Cannas, brilliant colors
No. 13-15 Rainoow Pansies

No, $14-8$ Beautifu Fuchias

No. 15- 8 Splendid Begonias

No. 16-15 Mammoth Verbenas

No. 17-12 Assorted plants for pots or bedding

No. 18- 8 Fine Basket of Vase Plants

No. $19-8$ Double Fringed Petunias.

No. 20-12 Lantanas, fine for bedding

No. $21-8$ Hibiscus, Double aud Single

No. $22-8$ Heliotropes, very fragrant

No. $23-8$ Violets

No. $24-6$ Hardy Phlox
$50 \mathrm{c}$

$50 \mathrm{c}$

$50 \mathrm{c}$

$50 \mathrm{c}$

$50 \mathrm{c}$

$50 \mathrm{c}$

$50 \mathrm{c}$

$50 \mathrm{c}$

$50 c$

$50 \mathrm{c}$

$50 \mathrm{c}$ $50 \mathrm{c}$

No promiums or discounts allowed on these Collections, which are sent postpaid by mail.

When ordering sent by express, purchaser paying charges, we will send any three sets for $\$ 1,25$, or ang five sets for $\$ 2.00$ 


\section{RETAIL DEPARTMENT \\ JOS. W. VESTAL \& SON \\ Little Rock, Ark.}

PLEASE DO NOT WRITE HERE

PLEASE READ "Information PIEA Purchas to prevent misunderstanding.

Date

1913

\section{AMOUNT ENCLOSED}

$\$$

(State whether Cash, Draft, P. O. Or der, Express Money Order or Stamps.)

Fo. vard Now or About ..................................................................................

We Deliver Free in the United States all orders suitable to go by mail. When goods are sent by Express, purchaser pays the charges unless otherwise
agreed. Safe arrlval guaranteed. Please read page 3. ARTICLES WANTED

PRIC Quantity ARTICLES WANTED

PRICE 


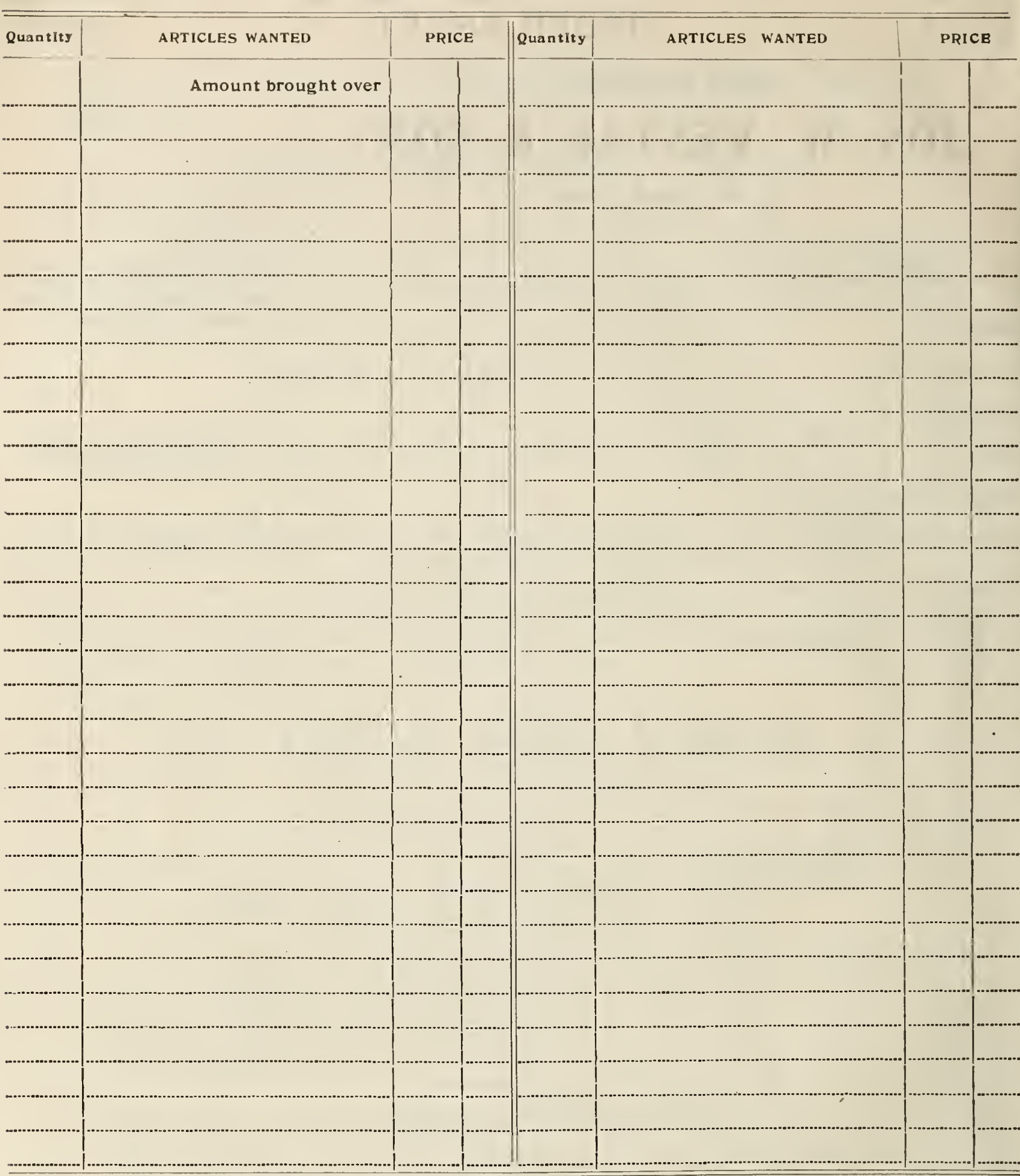

OUR CATALOGUE FREE TO YOUR FRIENDS, ESPECIALLY NEW HOME BUILDERS

We will consider it a favor if you will give us, in spaces below, the names and addresses of a few friends and acquaintances, especially rew home bullders, whom you know to be interested in Bulbs, Plants or Seeds, that we may send each of them coples of our different catalogues as issued. 


\section{Information for Purchasers}

Wh ARE LEADIXG GROWERS of the newest and choicest Roses and other beautiful flowers. OLR NEW GUIDE IS OUR STORE, where our patrons can shop at convenience. Prices are plainly marked, and everything suitable to go by mail is DELIVERED FREE at the prices named. We give close personal attention to every part of our business, and are always glad to accommodate and assist our cnstomers in every way we can.

\begin{abstract}
WHEN YOU ORDER
please use the printed envelope and order sheet enclosed. Others will be sent yon npon request. Always write your name the sanc, adding the postuffice, county and state on each and every communication you send us. If you have occasion to write us, please use a separate sheet.

IF YOU WISH ORDERS HELD wise we will send once or acknowledge their receipt. We work nights when necessary, and always try to ship promptly. Always men. tion your order number when writing us. (See "Lost Orders" below.)

HOW TO SEND MONEY Our terms are cash. To avoid the order. Money may he sent at our risk if forwarded by P. O. Money Order, Express Money Order, Bank Draft or in Registered Letter, and cost of same may be deducted from amount forwarded; but we cannot be responsible for any order or money that fails to reach us when not sent as above directed. CASH should be sent by Registered Letter, but coins should be carefully wrapped and care taken to seal the letter securely. New postage stamps accepted for small amounts.
\end{abstract}

AGENTS We employ no agents, and are only responsible OUR GUARANTEF We guarantee all plants to reach condition.

OUR RFSPONSIRILITY As stated below, we guarantee nation in a live condition, but when to reach their destiresponsibility ceases, because we know that if they receive proper treatment they will grow nicely. Many plants die from careless treatment and neglect; in such cases we cannot and should not be expected to replace them.

ERRORS As an evidence of our human failings we sometimes make mistakes. Careful as we ar to protect ourselves and our patrons, preach as much as we will to our employes, yet they occur; when they do, notify us at once and we will correct them promptly.

SHOULD YOU RECEIVE two or more Catalogues alike, the kindness to as yon do not need to other ants. By doing so, confer a double ill also feel thankful for your recommendations of our establishment to your friends wanting plants. A copy of our Catalogue will be furnished to friends re quiring plants on receipt of their address.

WHEN SENDING CLUB ORDERS please give full of each member of the club, so that we may enter their names on our books and forward them our Catalogues as issued.

BY OUR CAREFUL PACKING we are able to send of the United States with perfect safety. "Please fart us with an early order while stock is complete.

UNPACKING PLANTS when the plants are received, if, defer immediate planting, place the plants in the cellar or any moderately warm place, the plants in the cellar them upright, admitting the frotect from the sun, set watcr freely from time to time. circulation of air, and around the roots will be beneficial. Soak the roots in luke-warm water or thin mud for an hour or so before planting, to restore their vitality.

CORRESPONDENCF We invite correspondence on any glad to give you any information and suggestions on any subject within our knowledge. When writing about plants on an order, write on the order sheet, and when makin an inquiry concerning plants not ordered, use a separate sheet, as our order and correspondence departments are conducted separately. When writing about an order, be sure and furnish complete information, so that it will not be necessary for us to look up records, as this always be necessary
causes delays.

OUR PRICES will compare favorably, we believe, with United States. We guarantee our goods to give in the tion and every shipment is sent out under our satisfacof safe delivery at your door.
ORDERS BY EXPRESS Two year old roses, large sizo are too large to recommend that customers instruct is to ship smaller plants also by express, when in our judgment it is best to do so. We can send larger plants this way and can leave most of the earth on roots, which is of course much better for our customers. Express Charges mnst be paid by the purchaser, unless otherwise agreed. But we are careful to pack as light as safety of the plants will permit and add as many cxtras as we can afford to help cover charges, and since the expressage on plants, bulbs, etc. is now twenty per cent less than regular merchandise rates, the cost of sending goods in this way, even to distant points, is quite reasonable.

LOST OR UNSIGNED ORDERS Letters are often sent If you do not hear from us within a reasonable time, please send us a duplicate of your order, stating when and in what form payment was sent and sign the name and address the same as in the frst order, so that it may have immediate attention.

PREMIUMS NOT ALLOWED on Fruits, Special ofitems bought at one hundred or dozen rates, but cnstomers may select premiums on all things bought at single rates, as follows: On $\$ 1.00^{\prime} \mathrm{s}$ worth of goods bought at single rates, select to the value of 15 cents extra; $\$ 2.00^{\prime} \mathrm{s}$ worth, 30 cents extra; $\$ 3.00$ 's worth, 50 cents extra; $\$ 4.00$ 's worth, 70 cents extra; $\$ 5.00$ 's worth, $\$ 1.00$ extra; $\$ 6.00$ 's worth, $\$ 1.20$ extra; $\$ 10.00$ 's worth, $\$ 2.50$ extra; $\$ 11.00$ 's worth, $\$ 2.75$ extra; $\$ 20.00$ 's worth, $\$ 6.00$ extra; $\$ 25.00$ 's worth, $\$ 7.50$ extra. These premiums cannot be allowed on Special Offers, Collections or goods bought at dozen rates, or seeds in bulk.

CAUTION Prices on goods sold at special rates (i. e. by as low as we can afford; hence, on goods bought at these rates no further preminms can be allowed.

WHEN YOU ASK US TO SELECT When the selec we select a suitable proportion of the most desirable colors and varieties, and send by mail or express as directed. If you let us know any varieties you would like to have, or any you do not want, we will select as near as our stock will permit, and guarantee to please.

OUR FALL CATALOGUE of Imported Bulbs, Plants and winter blooming will be ready about September 1st, and sent to all our patrons of this year without request; to others free on application. If not received promptly, a postal card will bring it.

BETTER THAN WE PROMISE We always do better way of extra plants, so when the order will at all afford it we add to it some plant or plants gratis, often choice new kinds; several of the Roses now so eagerly sought after were first introduced to our customers in this waypresented with their order.

\section{A GUARANTEE THAT MEANS SOMETHING.}

Do not be confused with senseless guarantees which mean nothing. The best guarantee is that given by a reputable house to deliver all goods to any postoffice or express office in the United States or Canada in first-class growing condition, and failing therein, to replace them immediately. THIS IS OUR GUARANTEE. Furthermore, We guarantee that when goods are received, if they are nit
thoroughly satisfactory, we will make them so or REFUND YOUR MONEY. When plants reach you in good condition and are planted with ordinary care there is no difficulty in guaranteeing them to bloom at the time nature intended they should, which is sometimes termed "'a seasonable time." It would be quite as sensible if we were to guarantee that they would bloom at any other time but at the time nature intended that they should, the so.called seasonable time. We are sure that a guarantee that states that Plants are guaranteed to bloom under the above conditions, PROVIDED THEY ARE NOT WINTER KILLED OR DIE FROM ANY OTHER CAUSE, will be taken for what it is worth. Vestal's Plants are guaranteed to reach you in first-class condition, and if you give them any kind of care, WE GUARANTEE THEM TO GROW AND BLOOM. 


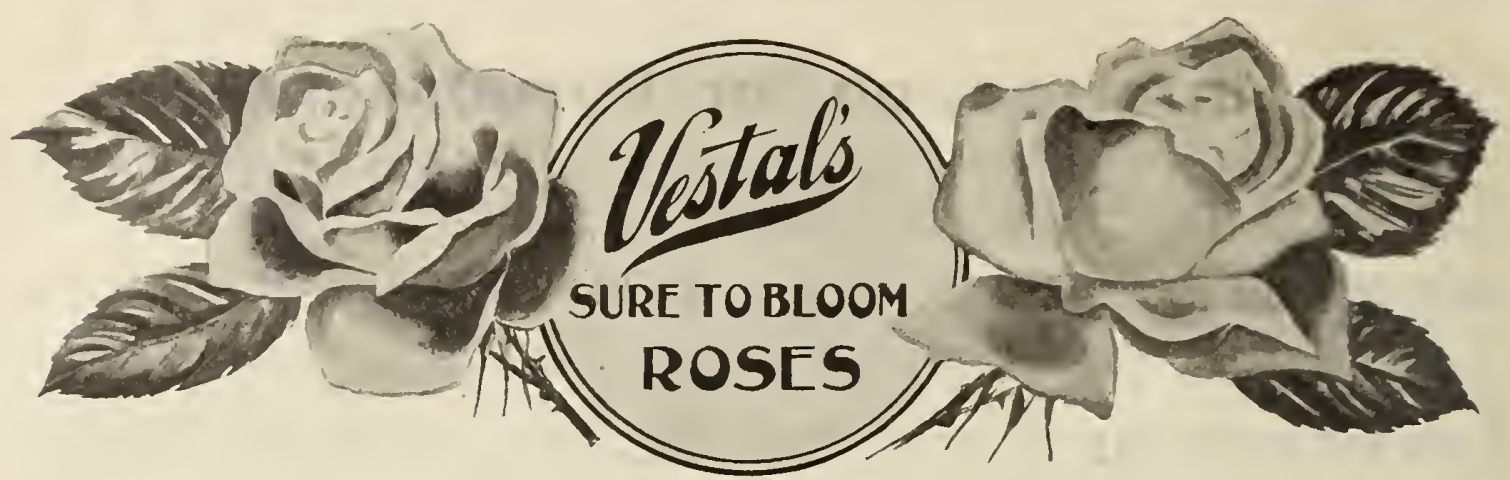

The wise purchaser in selecting what he wishes to buy considers the price of an article ONLY AS A GUIDE. It is Quality offered, which he needs most to know especially when buying Roses. Roses bought at bargain counters often prove to be very expensive before you are done with them. The question which mainly concerns a wisc buyer of Roses is not "What do these Roses cost me?" but "What will these Roses do for me?" Herctofore anyone who bought Roses had to get them on risk. It was a gamble- sometimes they bloomed and sometimes not.

\section{How to Grow Roses}

OUR SPEGIALTY We have for years made Roses our ular attention to their culture, so that our Roses are ular attention to their culture, so that our Roses are
famed for their thrifty condition; besides, we offer nothing but varieties of established merit and new sorts which have been thoroughly tested by us; hence we offer unequaled advantages to buyers of Roses.

OUR CLAIM We claim that we send out larger and any other firm in the usually sent out by the mailing trade throughout the country and our system of growing Roses makes them country and ou

PREPARATION OF THE SOIL Should the soil you naturally poor, it may be made fertile by substituting a quantity of loam, which can be readily obtained from the sod by the roadside of from the fields. To still further enrich the soil, where it is accessible, add to each wheelbarrow-load of loam about one-third of its bulk of well. rotted stable manure; also some sand if there be a lack of this constituent; or use fine, well-decomposed stable manure, which is the best fertilizer for general purposes. If this cannot be obtained, fine ground bone or commercial fertilizers may be employed, but if used too freely they are likely to injure the plant's. None but such fertilizers as are free from acids should be used. Manure applied in the fall will serve as a partial protection over winter, and in the spring it will be beneficial as a mulch. An excel'ent plant-food, which may be used at all times with entire safety, is Bowker's, offered elsewhere in this book.

Having prepared the ground, set the plants about 12 to 18 inches apart. Do not hesitate to place the roots well below the surface of the soil, arranging them as far as possible in their natural position. Cover the roots, pressing firmly down upon them and in around the stem. After planting, water freely, and, if the sun be strong, protect them for a few days with a covering of newspapers or other suitable material. Cut of all withered wood and foliage. Water judiciously-that is, not too freely-and daily, until they show signs of having become established. Do not plant if the ground is wet, as the soil will become baked, and thus endanger the safety of the plants. During the presence of protracted drought, the plants should be watered daily in the evenings. A little care and forethought exercised when the plants are small will have their. reward in great, sturdy, vigorous bushes in a wonderfully

PLANTING The proper time for planting in the various upon the sections of the country largely depends first, plant. In the warm climate of the Pacific cosst, southern plant. In the warm climate of the Pacinc coast, southern are infrequent and the winters mild, pot-grown as well as dormant Roses may be planted in the late fall, as well as in the early spring. In the southern states fall planting of both these classes of Roses is considered desirable, but. if the conditions are such that it cannot be accomplished, then, in the early spring months they may be set out with entire safety.

As to where the preference lies between plants that are pot-grown under glass, and dormant, field-grown plants, it is not easy to discriminate. Our own experience has been that in the southern and southwestern states, as well as on the Pacific coast, the planting of the one-year-old Roses during the months of February, March and April, Roses during the months of February, March and April, did satisfaction.
Everything considered, however, our pot.grown Roses are the most satisfactory of all. They are invariably on their own roots, and, when set out, they have the advantage of being equipped with strong fibrous, active roots, which take hold and establish themselves in their new homes almost immediately. They should be set out during the spring or early summer months, after all danger of frost is past or, to quote a homely expression, after corn-planting time. For planting in the open ground ordinary ing time. For planting in the open ground ordinary garden soil will suffice. Select, if possible, the most
sheltered and sunny location for planting; aroid the close proximity of large trees, whose dense foliage and extending roots absorb all the life and sustaining nutrition of the soil; young trees and dwarf shrubbery will not be hurtful.

WINTER PROTECTION If winter protection is neces WITER PROTEUTIUN sary in your section a good plan is to bend the branches, or the whole plant, down the ground by tying them to stakes driven in for that purpose, then spread dry leaves or garden litter over them to 2 depth of say six inches, but do not cover too thickly. or until the plants are well matured and leaves fallen off. and uncover gradually in the spring when danger of severe freezing is over.

ROSES HURT WITH THE WEATHER When Roses are ER hurt with the wood, and if you have "Own Root Roses" and the roots are not hurt, they will soon throw up new shoots and bloom as well as ever.

PRINNNG All Roses are helped by pruning. The different varieties of Roses differ very much in habit of growth; many are neat and compact, requiring little or no trimming, while others of the same class are vigorous and straggling, sending out long shoots which tend to outrun the limits assigned them. Pruning therefore is a matter to be governed by the judgment of the possessor of the plants. We will add. however, that plants of persisteut growth should be trimmed back each fall or in early spring about one-half to two-thirds of the season's growth. Where plants, apparently healthy, fail to mature the buds which they bear, remove a large percentage of the undeveloped buds and imperfect bloons aud prune severely. Also trim back about one-third, when, after planting. they shed their leaves and exhibit signs of weakness; this gives the roots a chance to become vigorous.

MULCHING By mulching is meant covering the ground MLIING around the plant with a uore or less thick coating of stable manure, leaves, sods, newly mown grass from the lawn, or other similar material. This may be done in the winter to keep from freezing too deeply, or in the summer to keep the weeds down, and is an excellent way to apply manure, as the strength will soak gradually down to the roots in the best possible way to nourish the plants.

ROSES NEED ALL THE SUNSHINE thes can get, and when planted in an open, sunny situation. They do not like shade or damp, wet ground, and should never be not where they will be deprived of proper nourishment by the roots of trees or older and stronger plants, which some. times extend long distances and completely exhaust the soil for anything else. This does not mean that a block of trees or shrubbery may not be utilized sometimes as a convenient shelter or windbreak for the Rose bed, only do not set them too near, and be sure their roots do not rub the Roses. A somewhat sheltered position when free from the above objections, is an ideal place for the Rose bed. 
INSECTS AND INSECTICIDES Healthy, vigorous to the ravaces of insects than weak specimens which do not have the vitality to resist the onslaught of the per. nicious parasites. Our Roses are singularly free from inscets, owing to their vigor, but should they become insccts, owing to their vigor, but, should they become
infested, a few applications of a good insecticide will extcrminate them at the outset, after which very little or no trouble will be experienced. Onc of the most common of insects is the green fly, which will be found usually on Roses of weak growth. We, at times, find them attacking our Roses, but they are resdily removed by syringing with clear water or smoking with tobaces stems: bnt wherc cear watcr or smoking with tobaceo stems, bnt wherc is Sulpho-Tobacco Sorp, applied according to the printed dircctions on every package.

The red spider is an insect so small that it is not dis. ccrnible to the naked eye, infesting the underside of the foliage, and turning it as a rule, an unhealthy coppery red eolor. Where the plant is in vigorous growth, this insect is not be be found to any appreciable extent, except on the old folinge, which can be removed, but should it attack the growing foliage, frequent syringing with the insecticides named above, shonld be resorted to. The rose hoppers or thrips are not so prevalent, and a syringing will effectually exterminate the Rose-hopper, while the leaf rollers, which resemble butterfies, of yellowish white color, roll themselves up in the leaves of the Roses, and cau be picked off by hand. The Rose bug, Common in some localities and which appears during the early grow ing season, is one of the most pernicious inserts and can be removed only by vigilant and unceasing syringing with insecticides.

Rose grubs, which live in the ground, where they hatch out innumerable offspring, are found only in some localities, but they are very destructive, feeding on the roots of the Rose, and before one knows that the plant las been de stroyed thcy have accomplished their work. The only remedy is to dig into the ground and destroy them. If the soil is continuously affected with them, a good coating of air-slacked lime spadcd in well will prove helpful. We receive quite a few complaints of the foliage of Roses bcing covered with a white flour-like substance, and asking for a remedy. This is mildew which some varieties sre subject to, notably Crimson Rambler after it has finished its period of bloom. Mildew does not seriously damage, but makes the plant unsightly. The remedy is to dust the foliage in the morning while the dew is yet upon it with FLOWERS OF SULPHUR, which may be had at almost sny grocery or drug store. A few applications will suffice to kill the mildew effectually. The following receipts snd preparations are good. They should be applied both to the upper and the under surface of the foliage by means of a good sprinkler. We can supply the Tyrian Plsnt Sprinkler at prices given elsewhere in this book. All of these are inexpensive and very satisfactory and will add much to the joy of growing healthy Roses.

\section{SULPHO-TOBACCO SOAP}

For a cheap, effective, clean and harmless insecticide for amateur snd professional growers this is unexcelled. Quickly exterminates all insect life on plants and flowers in snd out of doors. Unsurpassed for rose bushes. It acts as a valuable fertilizer, reviving plant life. For domestic purposes it rids the house of cockroaches, snd is a superior wssh for dogs and all animals. Prevents poultry lice. You cannot afford to be without this well known insecticide if you desire to be successful in plant culture. A trisl will give highly gratifying results.

Three ounce cake, sufficlent for one and one-half gallons prepared solution, 10 cents. Malled postpald, 13 cents.

Eight ounce cake, sufficient for four gallons prepared solution, 20 cents. Mailed postpald, 28 cents.

\section{A WONDERFUL INSECT PEST EXTERMINATOR.}

The are daily in receipt of inquirieg from our patrons requesting information relative to the best snd safest way of destroying the numerous insect pests that sppear on their roses and other plants. We are plessed to offer here what we helieve to be the safest, 'surest and cheapest insect exterminator on the market.

\section{TOBACCO POWDER}

THE SPRINKIING KIND FOR SPRINKLING OR DUSTING ONLY

Is made from heavy black leaf tobacco, strong in nicotine, and so finely pulverized that it can be applied with an ordinary magazine bellows gun direct to plants, indoors or out, or sprinkled around the hothouse to keep the pests in freck. Price, one-pound package, 25 cents; if by mail, 40 cents.

DIRECTIONS: Tegetable and Outdoor Plants.-Sprinkle with powder when wet with dew.

House Plants.-Immediately after wetting.

Poultry Lice.-Take fowl by feet, head down, dusting well in the festhers. Apply at night.

Setting Hens.-Apply powder when first set; repeat dose a few days before chicks are due. A small quantity dusted in nests and roosts will be found beneficial.

Carpets.-Sprinkle on floor near edge before laying csrpets down.

\section{Bowker's Ammoniated Food for Flowers}

A new odorless Fertilizer for Pot plants. Makes plants grow and bloom luxuriantly, and drives insects from the soll.

It starts the plant at once into a healthy snd vigorous growth and abundant bloom. It drives worms and other troublesome insects from the soil It has no disagreeable odor, and is the only artificial fertilizer which can be

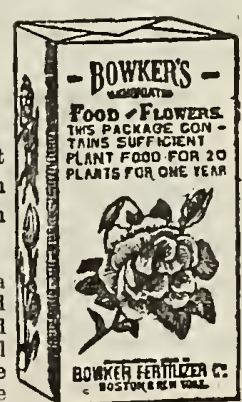
used without dsnger or injury to the plants. It takes the place of liquid manure, and is just the thing thst has been wanted for a long time. We have sold tens of thousands of packsges of $i t$, and have yet to hesr the first complaint. If your plants are doing poorly, get a packet and see how quickly they will be benefited. It acts like a charm. The Ammo nisted Food is put up in wooden boxes, with attrsctive wrappers. One package, sufficient for twenty-five ordinary sized plants for one year, for 50 cents. Sent by msil pastage prepaid, on receipt of price.

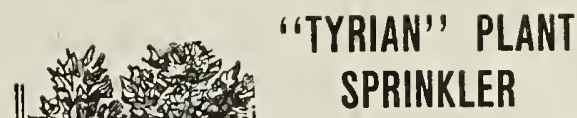

For Indoor and Outdoor Use.

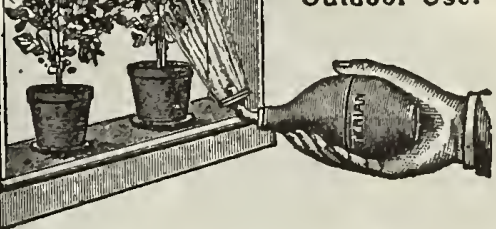

The "Tyrian" plant sprinkler is without question one of the most useful snd most hsndy srticles gbout the house, not only for the sprinkling of plants and flowers, but also used for sprinkling the floor and even clothes when ironing. This sprinkler should therefore be in ever. home. When using same for plants and flowers, especially when applying insecticides for the destruction of insects, we would advise to unscrew the head in filling same; but when water is used, by the pressing of said sprinkler, and placing in a ressel of water, it refills itself. We therefore advise everybody to get one, which will last yesrs. By advise everybody to get
mail, $\$ 1.10$, postpaid.

SLUG SHOT Is an Insecticide for the destruction of Potato and Rose Bugs, and all Lice, Worms or Caterpillars SLUG SHOI upon Melons, Eggs, Cucumbers, Ootton, Tobacco and Cabbage Plants, Tomatoes, Currants, Fruit or Ornamental Trees, Grape Vines, Shrubs snd Flowering Plants. An admirable remedy for the Black Olematis Bug.

DIRECTIONS FOR USE: Slug Shot is an impalpsble composite powder, to be dusted upon the plants. It contains Poison, thoroughly diffused through natural fertilizers, and is perfectly ssfe in its use to man or beast. PRICE, ONEPOUND PACEAGE, 25 CENTS, PREPAID. 


\section{The Most NEW ROSES OF 1913}

SOME OF THE BEST INTRODUCTIONS OF VARIOUS PROMINENT

On this and the following pages are offered the very latest introductions, and only those are offered that are superior to varieties of their class and color already in commerce. What we have here represents the highest degree of pcrfection yet attained in Roses, and as such they cannot fail to be of interest to cvery lover of new and rare varieties. The descriptions may be relied upon as being absolutely accurate. Right here let us say that we hare discarded in all our Rose departments such varieties that have not proven themselves to be thoroughly distinct and different from varieties that we already offer. This fact taken into consideration, we may fairly claim to have the most representative list of Roses to be found on this continent, or perhaps any part of the world. All our plants are of the strongest and cleanest character, sure to grow and give you the utmost satisfaction. Take our advice and give the new Roses a trial. Many of them are of marvelous beauty.

\section{RADIANCE}

In this variety we have an absolutely distinct and magnificent Rose of the highest excellence. It is a strong, vigorous grower, of free and erect branching habit, with very large and massive dark green foliage. Flowers very large and massive, of a lovely glowing pink color, distinctly shaded to white at base of the petals. The outer petals are shell shaped and extremely large, giving a half opened flower of great spread. This is a fine American pedigreed sort. A fine garden Rose. Price, one year old plants, 15 cents each; two year old plants, 35 cents each.

\section{SUNBURST}

This magnificent giant yellow Rose is a fine forcer; it stands head and shoulders above all others of its color. It has long, pointed buds, which can be cut tight for market. The color is orange-copper or golden.orange and golden-yellow; edge of petals lighter; all intense shades, golden-yellow; edge of petals lighter; all intense shades, extremely brilliant in effect. Belongs in the class of big
Roses; has created a sensation wherever shown. Price, one year old plants, 20 cents each; two year old plants, 50 cents each.

\section{MRS. THEODORE ROOSEVELT}

Creamy white, with rose center; bnd, long and pointed; flowers very large, full and of splendid form. A vigorous grower. Grand bedder. Its freedom of bloom is most remarkable, beginning on very small plants and continuing without interruption. Price, one year old plants, 20 cents each; two year old plants, 50 cents each.

\section{ANDRE GAMON}

A very vigorous grower of erect, branching habit; fine bronzy foliage, with long, finely shaped buds: the flowers are large, full and globular, carried well above the foliage upon rigid and strong stems. Color, deep rose and carmine, deeper on the edges. Price, one year old plants, 20 cents each; two year old plants, 50 cents each.

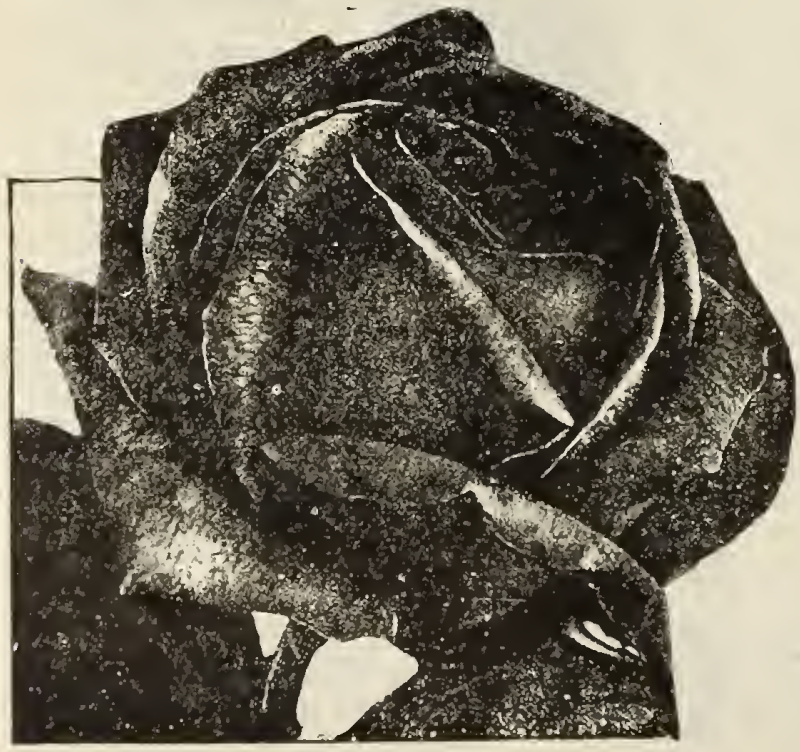

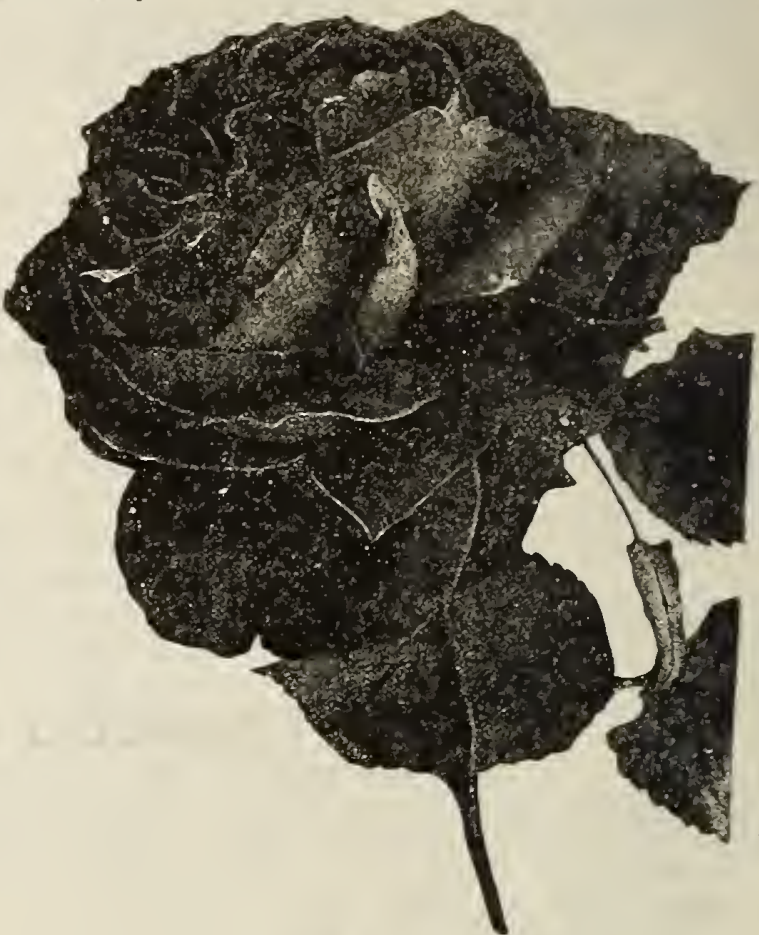

Prince E. C. D'Arenberg

\section{PRINCE E, G. D'ARENBERG}

Brilliant fiery scarlet, with buds of unusually good substance; a fine erect grower, with ample foliage. Price, one year old plants, 20 cents each; two year old plants, 40 cents each.

\section{MADAME SEGOND WEBER}

One of the grandest novelties of recent years; ercry. body is talking about it, and the more one knows of this wonderful Rose the more he will talk about it, and, what is of real value, every bit of talk about MIme. Segond Weber is in praise of her. Rosy-salmon or flesh pink in color, of the general type and color of "Mfy Maryland." The bud is long and pointed, opening into enormous blooms, which deepen its color until fully expanded, when it is as impressive as an "American Beauty." The tex. ture of the Rose is very thick and heary and the form of the petals peculiarly beautiful. A great garden Rose. Price, one year old plants, 15 cents each; two year old plants, 40 cents each.

\section{MADAME VALERE BEAUMEZ}

Cream, yellow and orange are the colors in this queenly Rose. All the tints exquisitely beautiful, form very full and nicely rounded; a strong grower. We feel sure that this Rose will rank in the dozen best bedders. Price, one year old plants, 20 cents each; two year old plants, 50 cents each.

\section{MELODY}

most charming and decidedly beautiful Rose, whicb attracted the attention of all visitors to our Rose gardens luring the past summer because of its marvelons freeblooming qualities. The blooms are of good size; the color is an intense, pure, deep saffron-yellow. with primrose edges; a delightful color harmony. A Rose of the highest merits. Price, one year old plants, 15 cents each; two year old plants, 40 cents each. 
NEW ROSES OF 1913-Continued

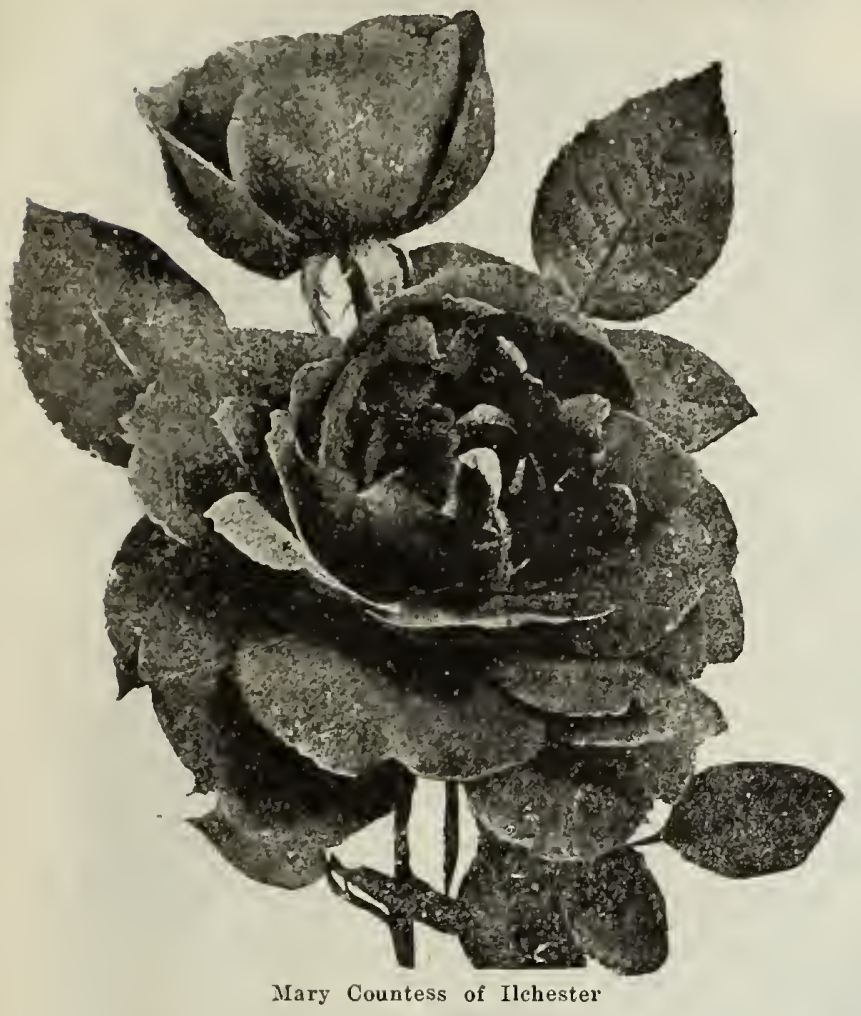

\section{FLORENCE EDITH COULTHWAITE}

An exquisitely beautiful bedding variety. The blooms are large and full, of perfectly imbricated form, the edges of the petals bcautifully ruffled. Color, deep cream stippled with bright rose on the inside petals and reflected on the back, thus creating an indescribable deli. cate orange and peach glow: quite distinct. One of the best. Price, one year old plants, 15 cents each; two year old plants, 40 cents each.

\section{EUGENE BOULLET}

This will become a standard variety. It las all the earmarks of a good Rose. Vigorous grower; free bloomer. The blooms are of the largest size; the color a rich ruby-red, and of delicious fragrance. Price, one year old plants, 15 cents each; two year old plants, 40 cents each.

\section{HELENE WATTINE}

White, with lemon-yellow center, very double and of the largest size, opening as flat as a plate; a vigorous grower and a very promising bedder. Has the beautiful form of Malmaisnn. Price, one year old plants, 15 cents each; two year old plants, 40 cents each.

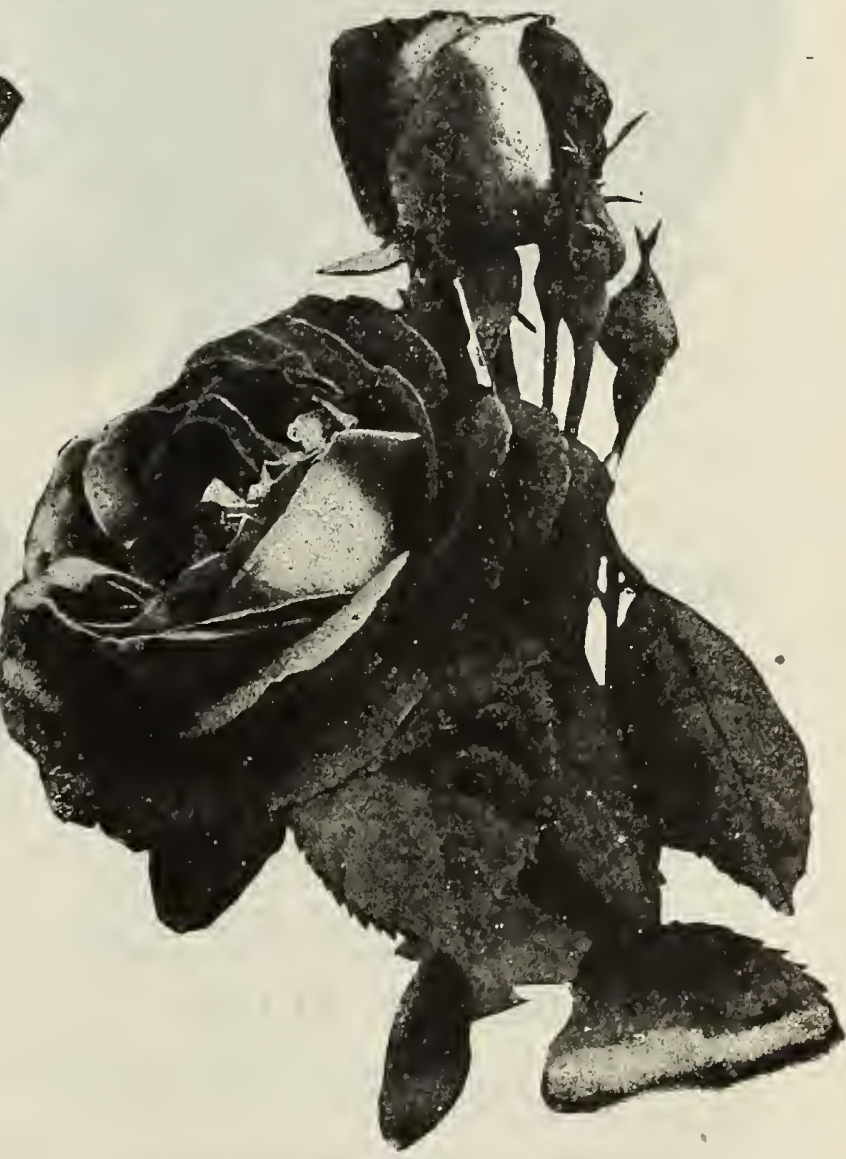

\section{MARY COUNTESS OF ILCHESTER}

In the opinion of many expert rosarians this must be classed as one of the finest novelties. Mr. Roger Mur phy, who has worked with Roses for the past forty years, says: "This Rose has come to stay. After try ing out all the novelties of the past five years, I place the Countess Mary first." 'The color is unique and distinct, being a warm crimson-carmine, a shade diffcult to describe: of great size, with large, smooth, circular petals, deliciously scented. Simply grand. Price, one year old plants, 15 cents each; two year old plants, 40 cents each.

\section{MARIE DELESALLE}

As free in growth as Teplitz, flowering continuously: buds long and elegant, opening into lovely blooms of fine form and large petals; color bright deep cerise. A decidedly free bedding Rose. Price, one year old plants, 15 cents each; two year old plants, 40 cents each.

\section{LADY HILLINGDON}

It las long willowy stems that are in no sense weak as the buds are held upright; has a long slender pointed bud of brilliant deep golden-yellow, and a striking peculiarity of this Rose was that each day the golden-yellow color became decper yellow and more intense, unlike all other yellow Roses of which we are familiar, as invariably the tendency after being cut is to get lighter in color. Price, one year old plants, 15 cents each; two year old plants, 40 cents each.

\section{MAMIE}

It is a strong grower, with buds and flowers of the largest and most perfect shape and form. The color is exquisite, being a delicate fawn with heart of pink. One of the most beautiful of light colored Roses. Don't forget this Rose. It will make a place for itself among the leaders. Price, one year old plants, 15 cents each; two year old plants, 40 cents each.

\section{F. R. PATZER}

A most beautiful and distinct Rose of very free flow. ering character. The blooms are produced with great freedom on stiff stems, and are of large size and substance. The color is creamy-buff, back of petals delicate warm pink; as the petals reflex the of petals delicate warm pink; as the petals reflex the color becomes light uable for garden culture. Price, one year old plants, 15 cents each; two year old plants, 40 cents each.

\section{FRIEORICHSRUHE}

Color deep blood red; large, full, well formed, flowering freely and continuously; excellent habit of growth. A splendid Rose. Price, one year old plants, 15 cents each; two year old plants, 40 cents each.

\section{LADY URSULA}

Color a most beautiful shide of flesh-pink, of great sub. stance and good form; petals large, circular and delicate. ly perfumed. A grand grower, producing its round, full blooms in wonderful profusion. Price, one year old plants, 15 cents each; two year old plants, 40 cents each. 


\section{NEW ROSES OF 1913-Concluded}

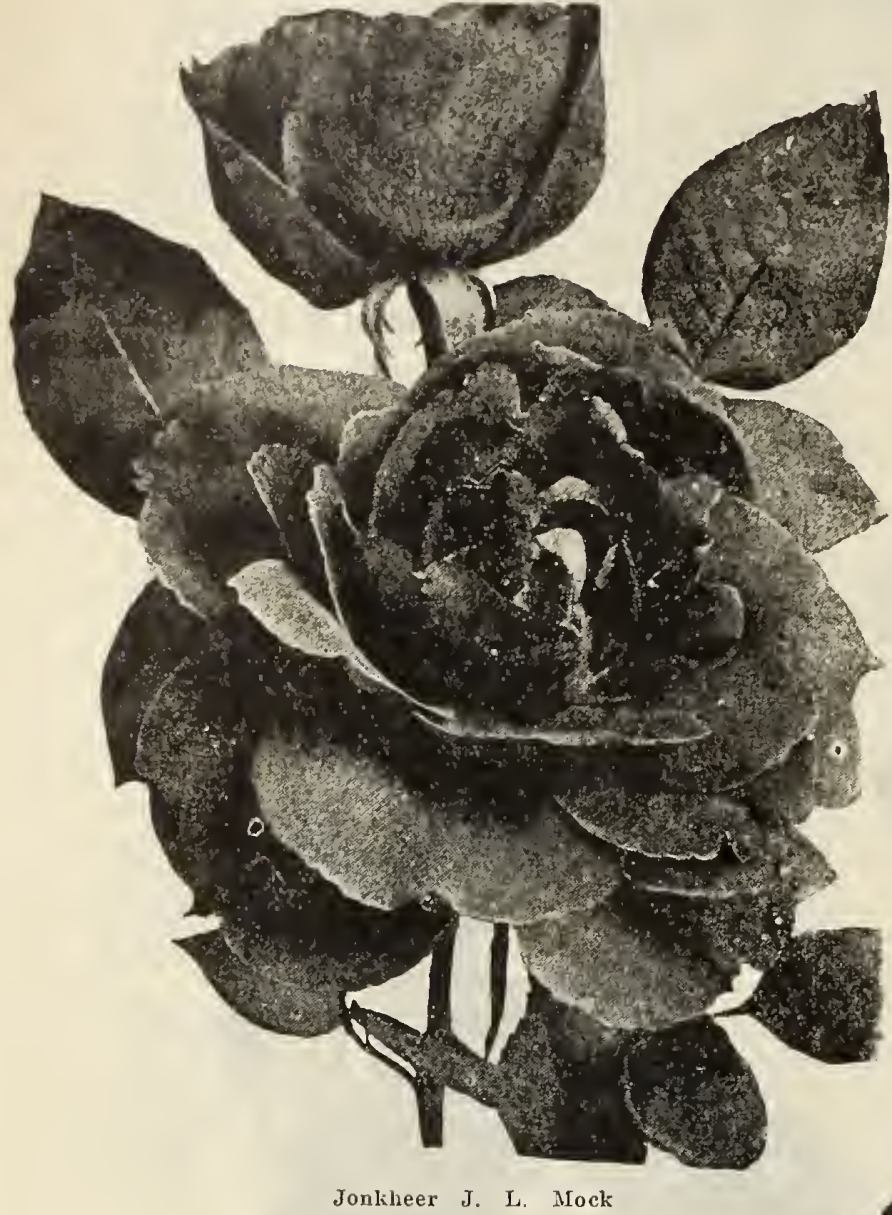

\section{ROSE QUEEN}

One of the most beautiful Roses produced in years Tbe color is an intense rose-pink, lustrous and deep. holding true to the last and in the brightest sunlight, a splendid quality in a bighly colored Rose. The form of the bud is long. slender and pointed, the ideal shape. As the buds expand the heart of the flower discloses a glowing color difficult to describe; very ricb and warm. The form of tbe open flower is splendid, not too double; it remains long in good condition. Price, one year plants, 20 cents each; two year plants, 50 cents each.

\section{HIS MAJESTY}

The color is a fine dark crimson, sbaded deep rer milion, crimson toward the edges, and frequently orerlaid with a rich velvety shading. It is a strong, rigor. ous grower; carrying its flowers upright; the blooms are full, with high pointed center of the exhibition type When seen at its best this is a noble flower. Price, one year plants, 15 cents each; two year plants, 40 cents each.

\section{GEORGE C. WAUD}

Orange-vermilion, remarkably distinct and beautiful: large, full, well formed; flowers freely; highly tea scented. One of the best. Price, one year plants, 15 cents each; two year plants, 40 cents each.

\section{PINK BEAUTY}

It is without question tbe most remarkable of all pink Roses. It has a slining, intense, deep pink color possessed by no other Rose. It is a fine grower, free bloomer, good size and form, fragrant, and in a class by itself as to color. It has an extraordinarily deep, long, very pointed flower, probably the most perfect sbaped and most graceful form of any Rose grown: lias no equal among bedding or garden Roses. Will be known as "Er. erybody's Rose.' Price, one year plants, 15 cents each; two year plants, 40 cents each.

\section{JONKHEER J. L. MOCK}

Tbis grand Rose is tbe strongest growing in the Hy- brid Tea class. Tbe blooms, whicb are produced with the greatest freedom, are carried on stiff and erect stems, and are of the largest size, of perfect formation and highly perfumed. Color, clear imperial pink; a glorious flower. We can confidently recommend this sterling nov. elty as a most valuable addition. Price, one year old plants, 15 cents each; two year old plants, 40 cents each.

\section{FLORENCE PEMBERTON}

Another splendid bedder, grand grower, magnificent in form, color and size; brilliant pink, shading lighter at the edges. Very fragrant. Price, one year old plants, 20 cents each; two year old plants, 50 cents each.

\section{MADAME P. EULER}

Vermilion-pink, changing to silvery-pink; very large, very full and possessing great lasting properties, perfect form: fragrant. Price, one year old plants, 15 cents each; two year old plants, 40 cents each.

\section{LADY ALICE STANLEY}

This, we predict, will become very popular as a garden Rose. The petals are shell-sbaped, forming a perfect flower; the color on outside of petals is a deep coralrose; inside, delicate flesh, of ten flushed and suffused witb bright flesh. Remarkably attractive, without doubt; a magnificent Rose. Price, one year plants, 20 cents each; two-year plants, 50 cents each.

\section{WILLIAM SHEAN}

A fine grower, throwing up long, stiff canes, crowned with large pointed flowers of purest Killarney pink, full, free and a perpetual bloomer. Immense size, perfect form and substance. Altogether a glorious Rose. Price, one year plants, 20 cents each; two year plants, 50 cents each.

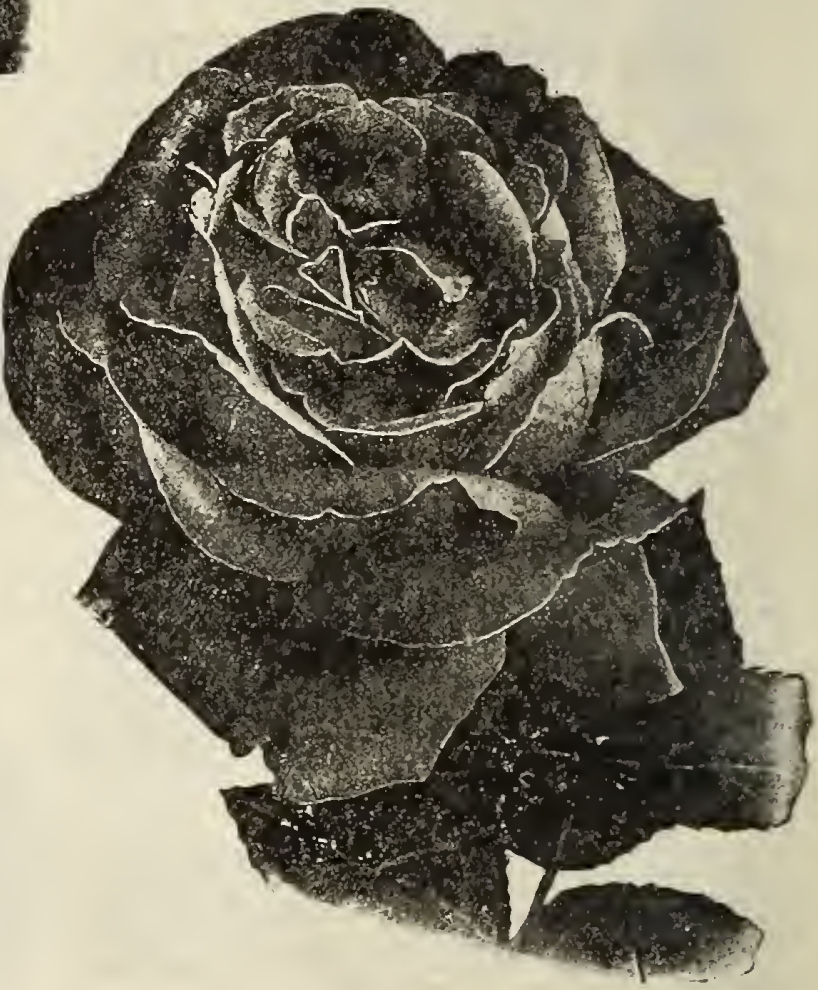

Pink Beauty

\section{PRICES IN QUANTITIES}

Where marked 10 cents each, 6 for 50 cents; $\$ 1.00$ per dozen.

Where marked 15 cents each, 4 for 50 cents; 10 for $\$ 1.00$.

Where marked 20 cents each, 3 for 50 cents; 7 for $\$ 1.00$. 


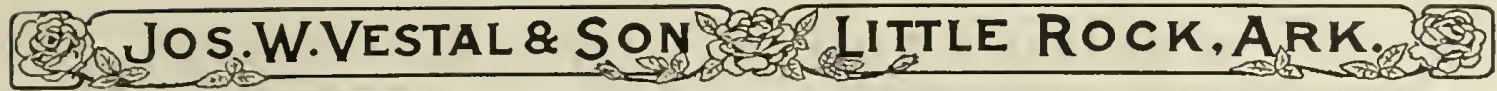

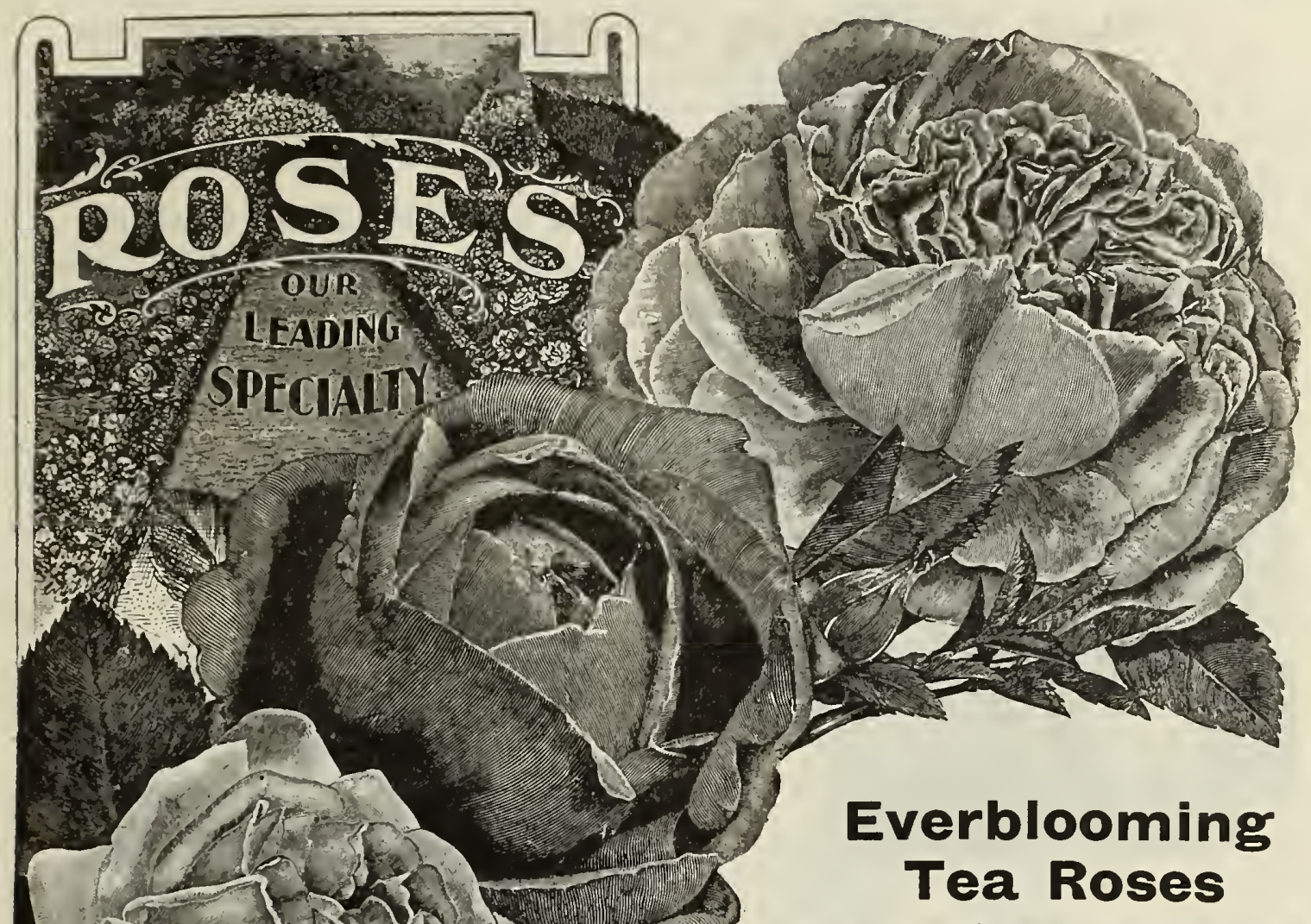

This class of Roses has proved itself better. than any other for general planting, more especially in open ground. Our one-year plants will bloom the first and each succeeding year, from early spring until severe frosts. Two-vear-old plants will yield a greater profusion of flowers the first year, of course, ying to their size, and are generally more satisfactory. The Flowers of the Everblooming Tea Roses are noted for their exquisite color and delightful fragrance. They are absolutely hardy in open ground, with a protection of litter, leaves, evergreen boughs similar material. We urge our friends to plant liberally of these Roses, as even the one-year plants will pive a harvest of bloom that will amply compensate for the trifling outlay re quired to secure a collection of them.

\section{ROSES ARE OUR SPECIALTY}

Since the founding of our business, forty-five years ago, we have continued to make roses our specialty, growing each season more stock to supply the increasing demand and where possible improving the quality of same. That we have succeeded in our undertaking must readily be acknowledged, our Roses being most widely and favorably known all over this section of the United States.

We have a distinct advantage in having here the best soil in America for rose-growing. Our plants grow larger, sturdier and more vigorous than can be secured from any other section of the country. Our reputation for sending out fine rose stock can be vouched for by thousands of satisfied customers who have dealt with us during the last decade.

\section{OUR YOUNG ROSE PLANTS}

We grow upwards of one-half a million of these young roses. Those offered this season are fine, healthy plants, propagated last summer and now in three-inch pots, They have been grown right and will, upon being planted, immediately start into vigorous growth and blossom profusely the first grown profusely the first season-this rear,-except a few of the Climbing and Hybrid Perpetual varieties, which generally do not bloom much until the second season. The young Roses are offered to supply a demand from planters who do not care to
purchase higher priced stock, such as we offer in our two-year Roses. We can send these roses by mail, but when possible, prefer to ship by express, perinitting us to leave the earth upon the roots.

\section{OUR TWO-YEAR OLD ROSES}

These roses are large, well-branched buslies, each having numerous stout canes. Every bush will bloom profusely the coming season. These roses must be shipped by express, being too large and heavy to send by mail.

WE FREQUENTLY RECEIVE COMPLAINTS from our patrons who order late in the spring; they state that the flowers produced on their Roses are very inferior and do not come up to description. We would state that perfect flowers cannot be expected from plants set out late and which produce blooms before they are well established. But if these plants are allowed to grow until the following fall, and, if they receive proper treatment, there will be no cause for complaint. 


\section{THE FAMOUS COCHET ROSES}

\section{SIX SUPERB NEW HARDY EVERBLOOMING VARIETIES}

Of the hundrcds of Roses offered in this book, these six superb, hardy, everblooming varieties are unquestionably the best. If you want six of the finest hardy sorts that will producc hundreds of superb flowers tliroughout the growing season, order the Cochet Set. No matter where you live, they will give you perfect satisfaction. They are abso lutely the best Roses in the world. Price of Cochet Roses, one year old plants, 15 cents each, set of six for 75 cents two ycar old plants, 35 cents each, set of six for $\$ 1.75$.

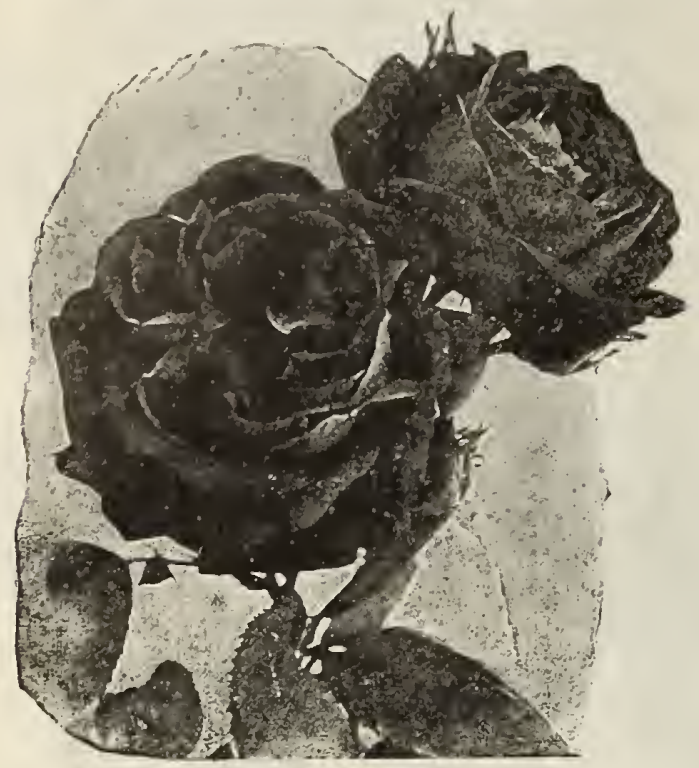

Crimson Maman Cochet

\section{Crimson Maman Cochet} (Etolle De France.)

This well known Rose we have named descriptively Crimson Maman Cochet, because of its vigor of growth, stiffness of stems, heaviness of foliage, freedom of bloom and hardiness. It bears masses of full, deep-formed flowers singly, on long, substantial stems. The color is a new and clear shade of red or crimson-velvet, brightening in center; of exquisite fragrance.

\section{RED MAMAN COCHET}

\section{(Helen Gould.)}

This is a Rose that will grow and rive satisfaction in almost any soil or situation. It produces its splendid flowers in amazing profusion, on long, strong shoots. For vigor and freedom of bloom, thousands of growers regard this Rose as better than American Beauty, and without a peer. The flowers are very full, perfectly double; buds long and pointed. Color warm, rosy crimson, hardy everywhere.

\section{YELLOW MAMAN COCHET}

We continue to regard this grand kind as absolutely the best hardy, everblooming yellow Rose. It is ideal for open-ground culture-a typical Cochet Rose, with gracefully molded buds, flowers magnificent when open, on stiff strong stems. This kind is identical in every way with Pink and White Cochet, except in the color of the flower, which is deep sulphur-yellow.

\section{WHITE MAMAN COCHET}

Identical with its parent, Maman Cochet, except in color, which is snowy white, with sometimes a faint tinge slightly suggesting pale blush. It has the same freedom of bloom, the same magnificent form of buds and flowers, and the same hardiness, - standing at the very head of all the Roses as the best white kind for openground culturc. Vigorous as an oak and hardy evcrywhere.

\section{BLUSH MAMAN COCHET (Wm, R. Smith.)}

Grand new Garden Rose, with beautiful, firm, glossy foliage, quite like Maman Cochet in appearance, wit flowers of heavy texture. Color, white, shading to pink. Succeeding admirably in open ground. Produces immense blooms on long, stiff stems.

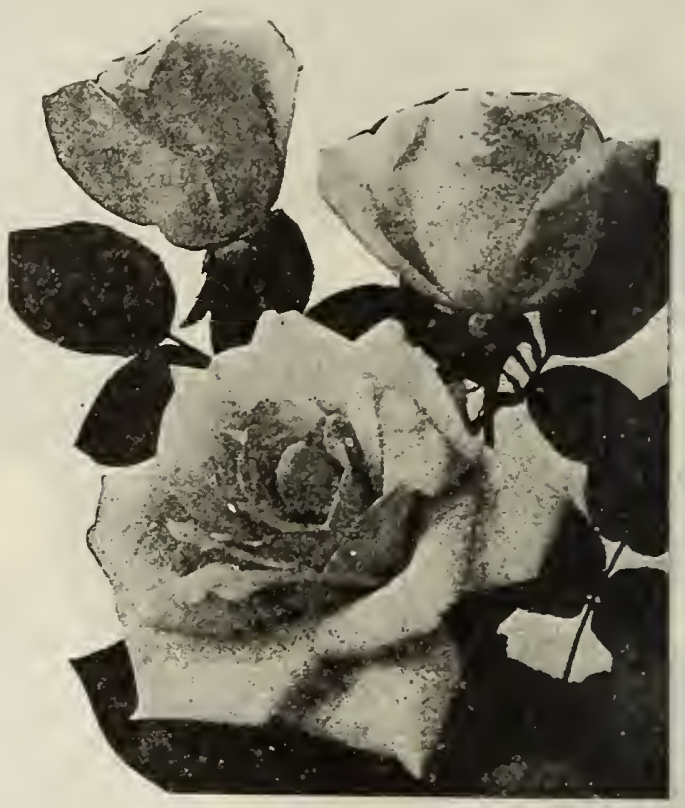

Pink Maman Cochet

\section{Pink Maman Cochet}

We have always regarded this as the Queen of all Pink Garden Roses, and as our friends become acquainted rith it they join us in similar admiration of its exquisite form and delicate beauty. The buds are large, full and firm, elegantly pointed, showing depth and richness as they expand. The superb flowers open perfectly double, are extra large and of splendid substance. Hardy in every section of the country; clear, rich pink, changing to silvery rose.

\section{EIGHT CHOICE EVERBLOOMING \\ ROSES FOR CEMETERY PLANTING}

WE WILL FURNISH THESE EIGHT CHOICE WHITE ROSES FOR 50 CENTS. NO DISCOUNT ON THIS OFFER. IN ORDERING SAY, "THE OEMETERY COLLECTION OF ROSES."

CORNEIIA COOK Very large, pure white buds and flowers. Excellent. Price, 10 cents each.

THE BRIDE. An excellent white rose, and very free flowering. Price, 10 cents each.

MARIE GUILLOT. This Rose is as perfect in bud and flower as a Camelia. Pure white in color. Price, 10 cents each.

WHITE COCHET. The Queen of all white Roses. The best rose for open ground culture. One of the best white roses for summer; hard to beat. Price, 15 cents each.
KAISERTN AUGUSTA VICTORIA Celebrated the world over for its elegant large pointed buds and full double flowers; creamy white; very fragrant. Price, 15 cents each.

SNOW FLAKE. New, Always in bloom. An elegant sort. Price, 10 cents each.

THE QUEEN. New. This rose is a beauty. Pure waxy white. Price, 10 cents each.

WHITE BOUGERE. A strong vigorous grower. Bads and flowers are of the very largest size, pure white in color Price, 10 cents each. 


\section{NEW ROSE WM. R. SMITH}

A VIGOROUS HEALTHY GROWER. EXCELLENT IN QUALITY. BOUNTIFUL IN BLOOM

Whether you live East, West, North or South, whether you wish one Rose or 1000 , here is a Rose which has our unqualified endorscment.

It will thrive abundantly in almost any reasonable Incation. The flowers are large, full and double and most exquisitely formed. The petals are so firm they look like wax, softly curled, colored cream with flesh tint tips, buff yellow base and the centcr a heart of pink. Perfect buds The flowers are borne on long, strong stems, just right for making bouquets. Fragrance is delightful. You will admire the foliage too, deep green leaves on red stems and the new growth of rich garnet; the plant will grow for you vigorously, is among the hardiest in this elass and blooms abundantly. Price, one year old plants, 15 cents each. two year old plants, 35 cents each.

\section{ROSEMARY}

A beautiful Rose of shining, silvery pink, recommended for bedding. Very large and very double; a sturdy grower with stiff stems and large foliage; flowers freely produced. Price, one year old plants, 20 cents each; two year old plants, 50 cents each.

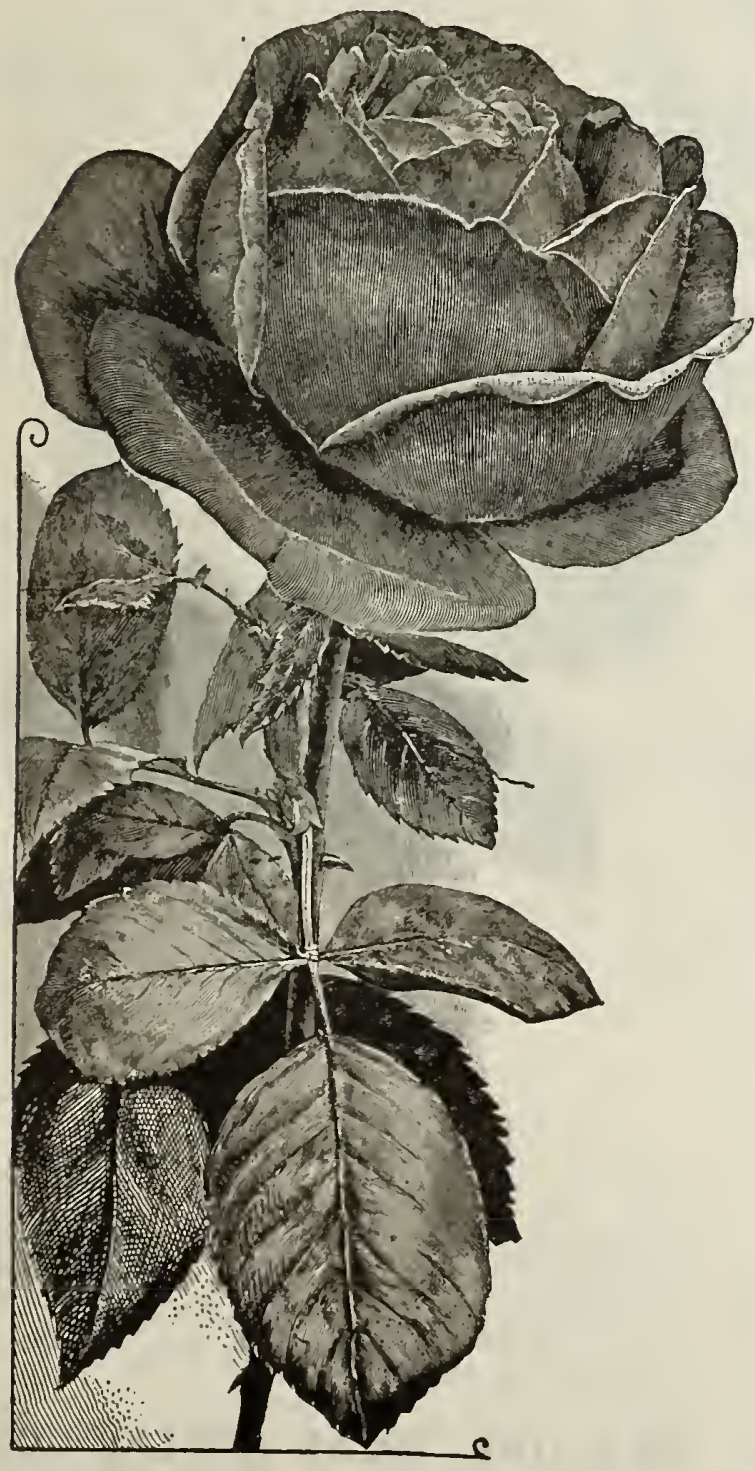

American Beauty

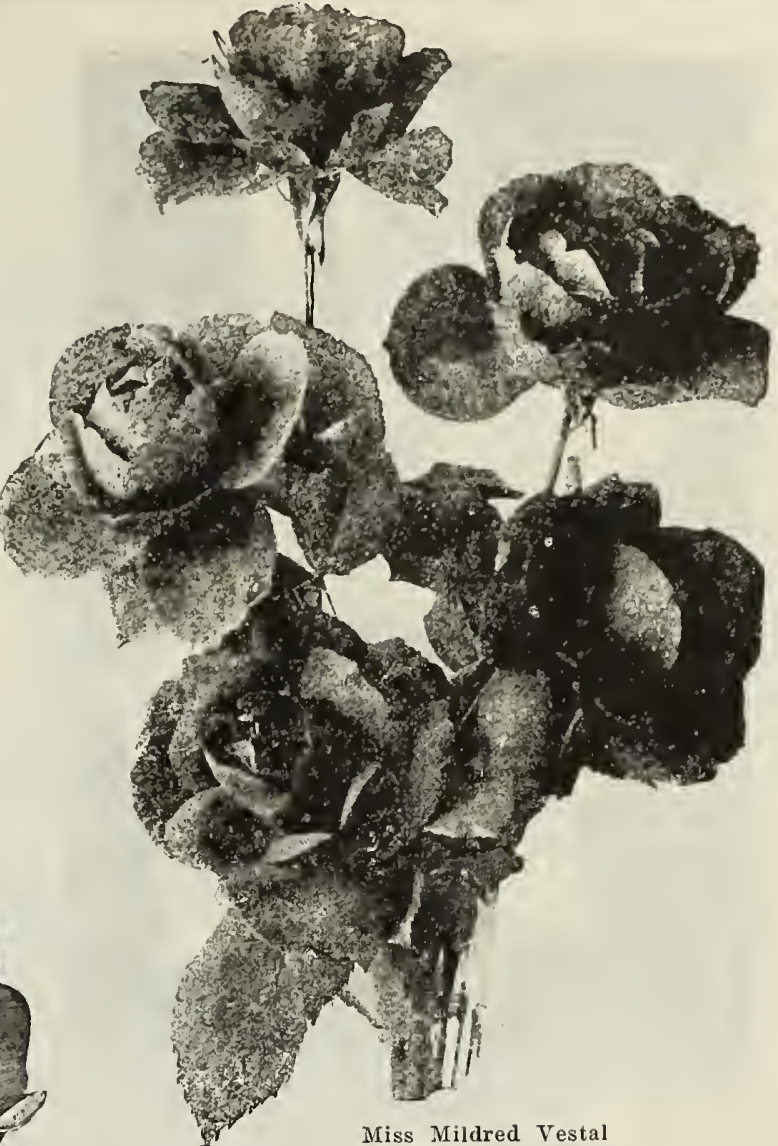

MISS MILDRED VESTAL

In introducing this variety, we wish to say that it is one of the best Hardy Everblooming Red Roses in existence. This superb new Rose is a result of a cross fertilization between "Rhea Reid," that grand red bed. ding Rose, and "Richmond," the greatest of all red forcing Roses, which insures in their offspring every point of excellence. It has magnificent large foliage, free from disease of all kinds, and is a tremendous growerone of the best in all bur list. The glory of the plant. however, is in the immense deep double flowers of a new and clear shade of crimson scarlet. It has withstood zero temperature. Price, one year old plants, 15 cents zero temperature. Price, one year old plants, 15 cent each; two year old plants, 35 cents each.

\section{RICHMOND}

It is our good fortune to have a fine stock of this grand Rose, which took the gold prize at the World's Fair at St. Louis for the best new Rose exhibited. There were hundreds of competitors for these great honors, and it at once stamps this Rose as a wonder for the judges did not hesitate one moment in awarding it first prize and a gold medal. In color it is a deep rich, velvety crimson, both buds and flowers are large and handsome; extra fine Price, one year old plants, 15 cents each; two year old plants, 30 cents each.

\section{AMERICAN BEAUTY}

The world famous Rose. This Rose has become as famous as the Marechal Niel. The flowers of this grand Rose are so eagerly sought that they sell in the flower stores of the larger cities during the holiday season at the extravagant price of from $\$ 1.50$ to $\$ 2.00$ for a single bud or flower. Indeed the market is never fully supplied with them even at this high price. It is because of its large size, rich color and delicious fragrance. It is a hardy Rose of the largest size, having the everblooming qualities of the Tea Rose, with the delicious odor of the Damask or Moss Rose. It is the sweetest of all Roses. In color it is a deep brilliant red, shading to a rich, carmine crimson. American Beauty is, like Marechal Niel, difficult to start from small plants, therefore we advise our customers to buy strong plants of it. This Rose will never be sold cheaply, for the reason that it is hard to propagate. Price, one year old plants, 15 cents each: large two year old plants, 50 cents each; extra large three year o:d plants, $\$ 1.00$ each. 


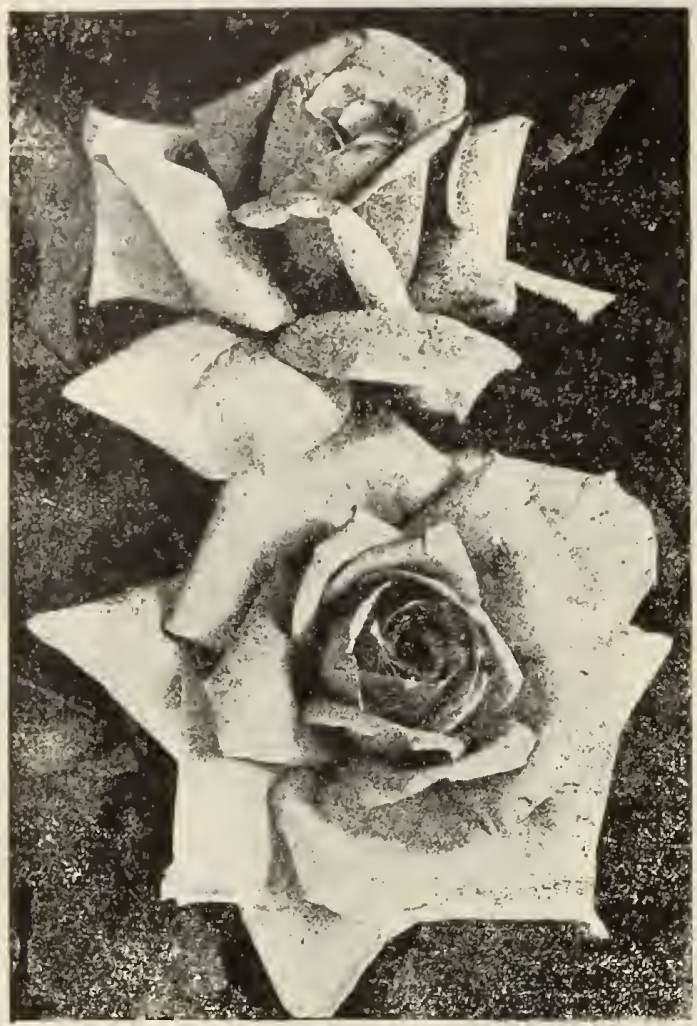

Kaiserin Augusta Victoria

\section{KAISERIN AUGUSTA VICTORIA}

A SUPERB, HARDY WHITE ROSE

This marvelous Rose has had many rivals for the place it still retains as the greatest White Rose in existence, Strong, sturdy grower, flowering with the ut most freedom. It holds first place as the most popular of white Roses for general planting. From early spring until late fall its glorious full-double flowers in all their perfection are produced continuously on long, stiff, erect stems color delicate creamy white, with a delicious mag. stems; color delicate creamy white, with a delicious mag. Price, one year old plants, 15 cents each; two year old Price, one year old plan
plants, 35 cents each.

\section{PERLE DES JARDINS}

\section{A Grand old Favorite}

This magnificent Rose still holds its position as one of the most exquisite and beautiful of its color ever in. troduced, and the demand for it is constantly increasing as its great value becomes known. Color a beautiful shade of clear golden yellow, entirely distinct from any other variety; fiowers large, full, globular form, with great depth. A strong, dwarf grower. Price, one year old plants, 10 cents each; two year old plants, 30 cents each.

\section{CARDINAL}

This magnificent, deep, rich red Rose is a welcome and long-boped-for addition to this class. Of American origin, it is the equal in form and color of any Rose in the list. Exceedingly free flowering; large, massive, full, double flowers, with exquisite fragrance. Color deep, rich crimson. Will thrive in almost any location. Price, one year old plants, 15 cents each; two year old plants, 40 cents each.

\section{RAINBOW}

This new Rose from California was awarded a silver cup by the State Floral Society. Color is a lovely shade of deep coral pink, striped and mottled in a most unique manner with intense crimson, and elegantly colored with rich golden amber at the center and base of petals. Price, 10 cents each; large size, 30 cents each.

\section{MADAME JULES GROLEZ}

Red Kalserin Augusta Victoria

One of the very best of the new Roses, and one that has o many good qualities that we are quite certain it will find a place in the garden of every flower-lover. It has been thoroughly tested by us and we have formed such a high opinion of it that, this year, we have grown an un usually large stock in order to give the Rose the widest possible distribution

Mad. Jules Grolez is an exceedingly freeblooming iety, with very large, finely formed flowers. The enlor is a distinct and charming shade of cherry-red. The fine form and attractive sliape of the flowers makes them ex cellent for cutting. Like Kaiserin Lugusta Victoria, Mad. Jules Grolez is a Rose of great value for open-ground culture. It is a remarkable strong growing rariety, as hardy as the Hybrid Perpetuals, free-blonming and in every way excellent. Price, one year old plants, 15 cents each; two year old plants, 35 cents each.

\section{MADAME JENNY GILLEMOT}

(The Yellow Kaiserin.)

Buds long and pointed deep saffron rellow, opening canary witl dark golden shadings; bloonis large, petals immense; opens very freely; a fine upright grower of branching habit. Exquisitely beautiful; very large in size; bud very long and pointed. Price, one year old plants, 20 cents each; two year old plants, 40 cents each.

\section{MAD. MASSON}

It is entirely hardy, blooms nearly all the time, bearing numbers of large, full, double flowers of unusual beaut. and wonderful fragrance; clear, bright rose: distinct and charming. A great Rose, Price, 15 cents each; two year old plants, 35 cents each.

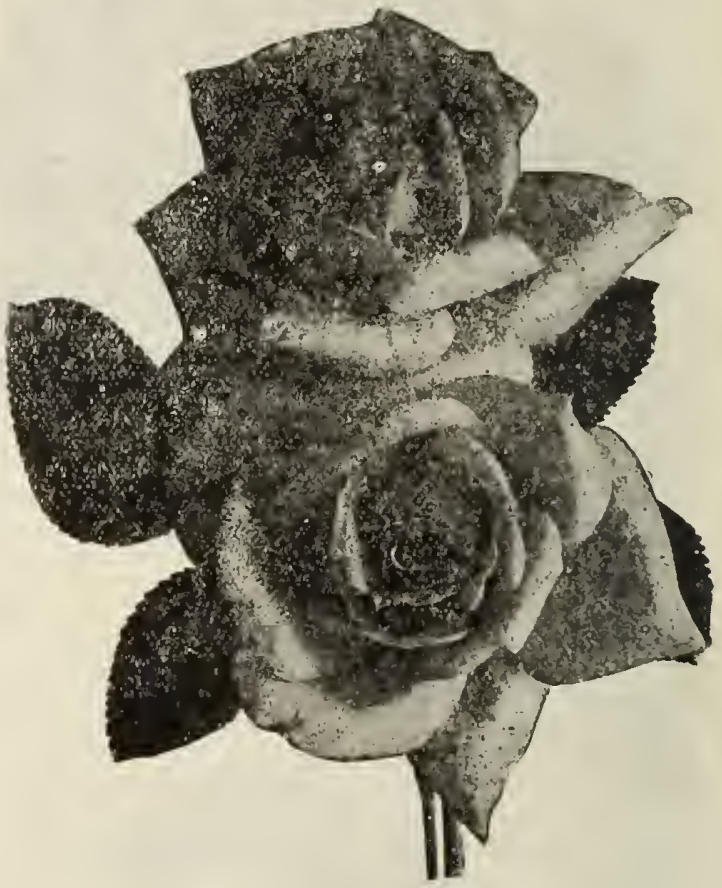

My Maryland

\section{MY MARYLAND}

Beautiful in Bud and Flower

A Rose of delightful color distinctive shape and super. fine name. In color it is an exquisite shade of pink, the buds and flowers being most beautifully formed and borne on long, stiff stems. The bush is extra strong, hardy and a most prodigious bloomer. Price, one year old plants, 15 cents each; two year old plants, 35 cents each.

TRY OUR TRIAL COLLECTION OF EVERBLOOMING ROSES. TWENTY CHOICE VARIETIES. Very Fine Plants. Best Sorts. Our Selection, $\$ 1.00$ Postpaid. 


\section{The Unexcelled La France Roses}

The La France Roses are of the highest merit, and each member of the family has particularly strong points:

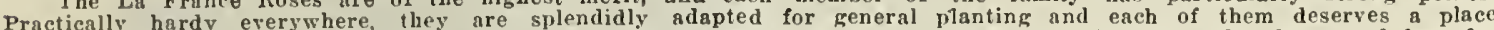
in every flower garden of America. Price of La France Roses, one year old plants, 15 cents each; the set of four for 50 cents; two year old plants, 35 cents each; the set of four for $\$ 1.25$.

PINK LA FRANCE

Exceedingly sweet and hsndsame; flowers nd buds size, color lorely slisde of sil rery pink, tinged with crimson; frsgrance delicious; flowers very full and wonderfully beau tiful. It commences to bloom snon after plant ing and continues until stopped by frost, and is hardy, with protection.

\section{WHITE LA FRANCE \\ (Augustine Guinoisseau.)}

A pure white member of the La France fam. ily, having just a tinge of rose-blush tint which grows stronger in the depth of the petals Buds and flowers extra large, very full and finely formed; exceedingly fragrsnt.

\section{RED LA FRANCE \\ (Duchess of Albany.)}

A superb rose; resembles the Pink La France, but is much deeper in color. It is a continuous and free bloomer, produces an abundance of lovely buds and Howers all through the sea. son; extra large, very double and full; remark ably fragrant; color brilliant rose-pink, exquisitely shaded.

\section{STRIPED LA FRANCE}

This Rose is almost exactly the same a Pink La France, except in color, which is bright satin, distinctly striped with bright rose.

\section{PLANT La FRANCE ROSES Great Bloomers, Combining Ele- gant Colors and Delicious Fragrance.}

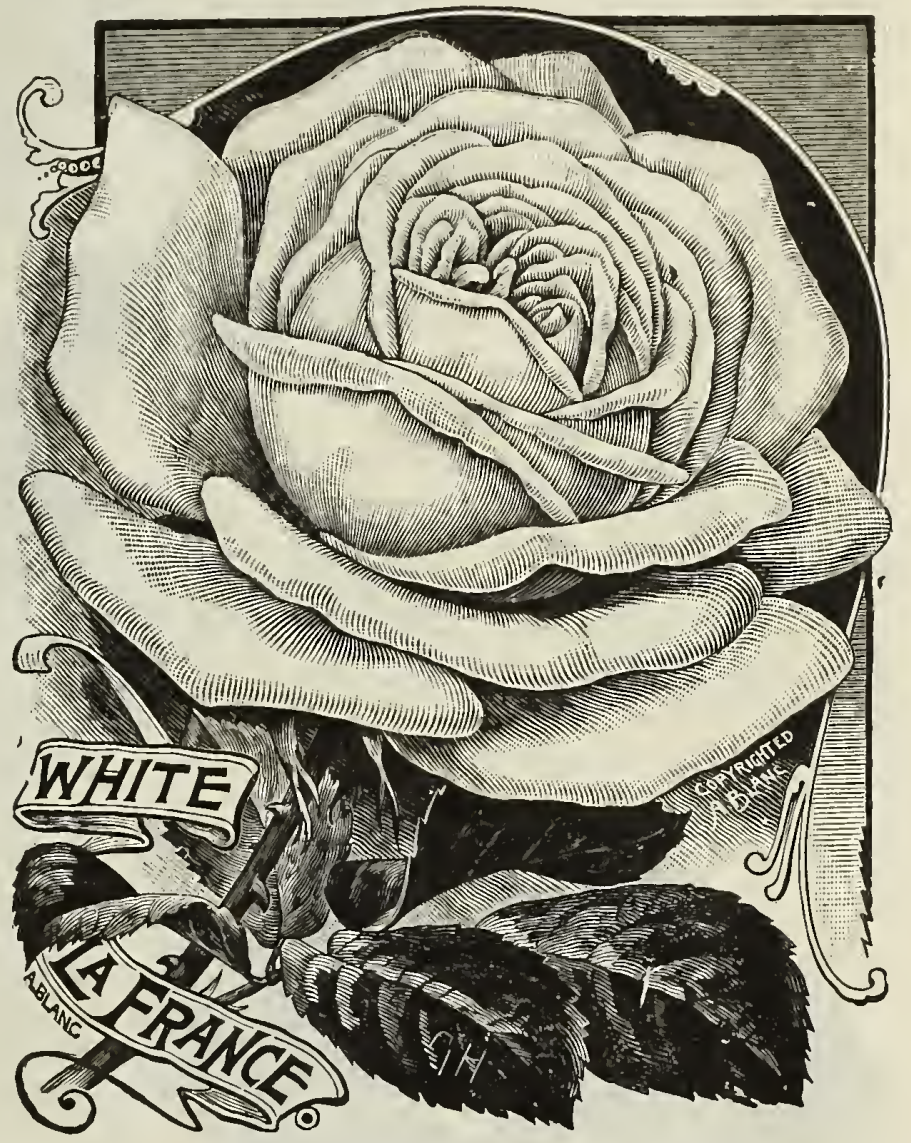

\section{SIX OTHER GOOD ROSES}

\section{QUEEN'S SCARLET}

Very best of all red Roses for bedding. Entirely hardy. The fowers are of larged Rize ond of these Roses produces a msss of red Gersniums. It is planted everywhere on account of its color and freedom of bloom. Price, 10 cents each; large size, 30 cents each.

\section{MARIE GUILLOT ONE OF OUR FINEST WHITE ROSES}

This beautiful Tea Rose continues in populsr fsvor, and still maintains its position as one of the best white Roses of its class. Flowers of an unusual style, entirely double to the center, snd very swcet scented. Price, one year old plants, 10 cents each; two year old plants, 30 cents each.

\section{SUZANNA BLANCHET}

One of the best Roses. Outdoors it grows splendidly, and blooms with such freedom as to make it one of the most satisfactory Roses for general cultivation. Color beautiful pale flesh, passing to silvery white, shaded with fine rosy amber: large finely pointed buds. Price, one year old plants, 10 cents each; two year old plants, 25 cents. each.

\section{AMI. STECHER}

A strong, vigorous grower with very beautiful foliage produces a perfect bud and a full, fragrant flower of brigh cerise red. A beautiful new Rose. Price, one year old plants, 15 cents each; two year old plants, 35 cents each.

\section{ADMIRAL SCHLEY}

Named in honor of the hero of Santiago, and in every way worthy of that illustrious distinction. Magnificent Hybrid Tea Rose, with flowers as finely formed as Meteor or Liberty. Deliciously fragrant, and in color a beautiful deep crimson. A strong grower, free bloomer, and a deep crimson. A strong grower, hree bloomer, and a We predict for it that it will become one of can citizen. We predict for it that it will become one of
the most famous of Roses. Price, one year old plants, 10 cents each; two year old plants, 30 cents each.

\section{MADAME LAMBARD}

The Great Southern Rose

A first class rose for garden planting or pot culture; habit of growth is vigorous and blooming quality very free. The color is a beautiful shade of rosy bronze; changing to salmon and fawn, shaded with carmine, A fine variety. Price, one year old plants, 10 cents each; fine variety. Price, one year old plants, 10 cents each;
two year old plants, 25 cents each. 


\title{
THE BRIDE
}

\section{A Standard White Rose of Exquisite Form and Color}

There is no other white Rose more satisfactory than The Bride. The buds and flowers are unusually large, well formed and deliciously perfumed. When planted in the open ground the flowers are sometimes found to be delicately tinted with pink, making it exceedingly attrac tive. It is of a strong and healthy growth and a profuse bloomer. Its blooms are of the most suitable form and quality for cut flowers. Price, one year old plants, 10 cents each; two year old plants, 35 cents each.

\section{BRIDESMAID}

\section{THE FAVORITE PINE TEA ROSE}

Miore plants of this are cultivated by the amateur, and more cut bloom is sold by the flower dealer than any pink Rose. The buds are of exquisite shape, solid and firm, and the stems are so long and stiff that no other Rose will compare with it in keeping qualities after being cut. Price, one year old plants, 10 cents each; two year old plants, 35 cents each.

\section{RHEA REID}

A Magnificent New Crimson Garden Rose

"As large as American Beauty, as double as La France and as red as Richmond," is the enthusiastic way in which the originator describes this beautiful new Hybrid Tea Bush Rose. The color is vivid scarlet-crimson, and the flowers are marvels of beauty, large, bold and of splen. did substance It has a strong, disease-resisting constitution, makes a rapid growth and throws up a profusion of canes from the roots and is always blooming Our ad. vice is to send for it and plant liberally of it. Price, one year old plants, 15 cents each; two year old plants, 35 cents each.
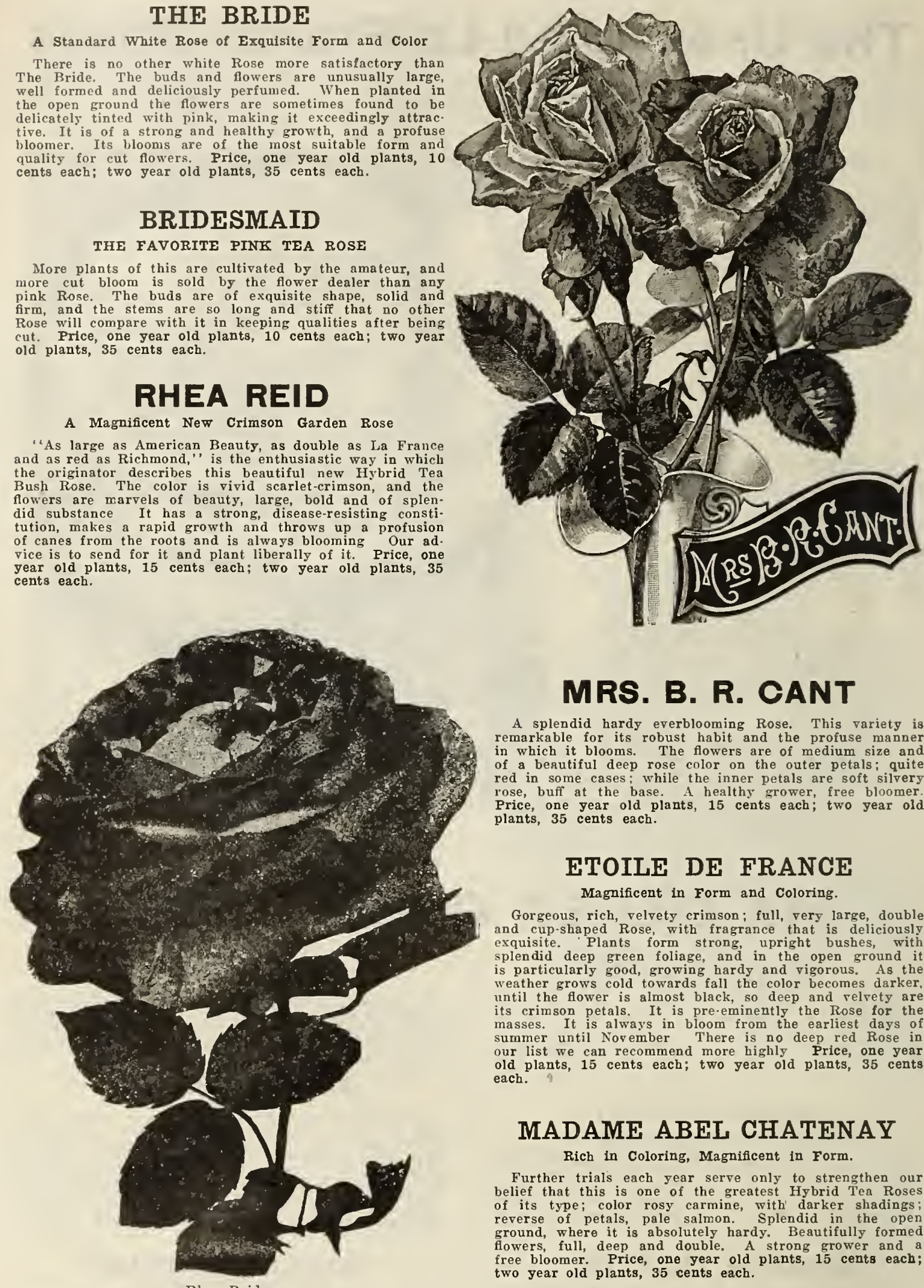

\section{MRS. B. R. CANT}

A splendid hardy everblooming Rose. This variety is remarkable for its robust habit and the profuse manner in which it blooms. The flowers are of medium size and of a berutiful deep rose color on the outer petals; quite red in some cases: while the inner petals are soft silver rose, buff at the base. A healthy grower, free bloomer Price, one year old plants, 15 cents each; two year old plants, 35 cents each.

\section{ETOILE DE FRANCE}

\author{
Magnificent in Form and Coloring.
}

Gorgeous, rich, velvety crimson; full, very large, double and cup-shaped Rose, with fragrance that is deliciously exquisite. Plants form strong, upright bushes, with splendid deep green foliage, and in the open ground it is particularly good, growing hardy and vigorous, As the weather grows cold towards fall the color becomes darker. until the flower is almost black, so deep and relvety are its crimson petals. It is pre-eminently the Rose for the masses. It is always in bloom from the earliest days of summer until November There is no deep red Rose in our list we can recommend more hichly Price, one year old plants, 15 cents each; two year old plants, 35 cents each.

\section{MADAME ABEL CHATENAY}

\author{
Rich in Coloring, Magnificent in Form.
}

Further trials each year serve only to strengthen our belief that this is one of the greatest Hybrid Tea Roses of its type; color rosy carmine, with darker shadings: reverse of petals, pale salmon. Splendid in the open ground, where it is absolutely hardy. Beautifully formed flowers, full, deep and double. A strong grower and a free bloomer. Price, one year old plants, 15 cents each; two year old plants, 35 cents each.

ORDFRS ARE SFNT BY FXPRFSS When requested or when too large to go by mail. Express charges are at ORDERS ARE SEIT BY EXPRESS expense of purchaser, hut we are careful to pack as light as the safety of the plants will permit, and add as many extras as we can afford to help cover the charges. As express charges on plants, bulbs, etc., are 20 per cent less than merchandise rates, we recommend that purchasers instruct us to send by express when in our judgment it is best; we can then send larger plants, and they are sure to arrive first class. 


\section{The New
Bedding Rose Gruss an Teplitz}

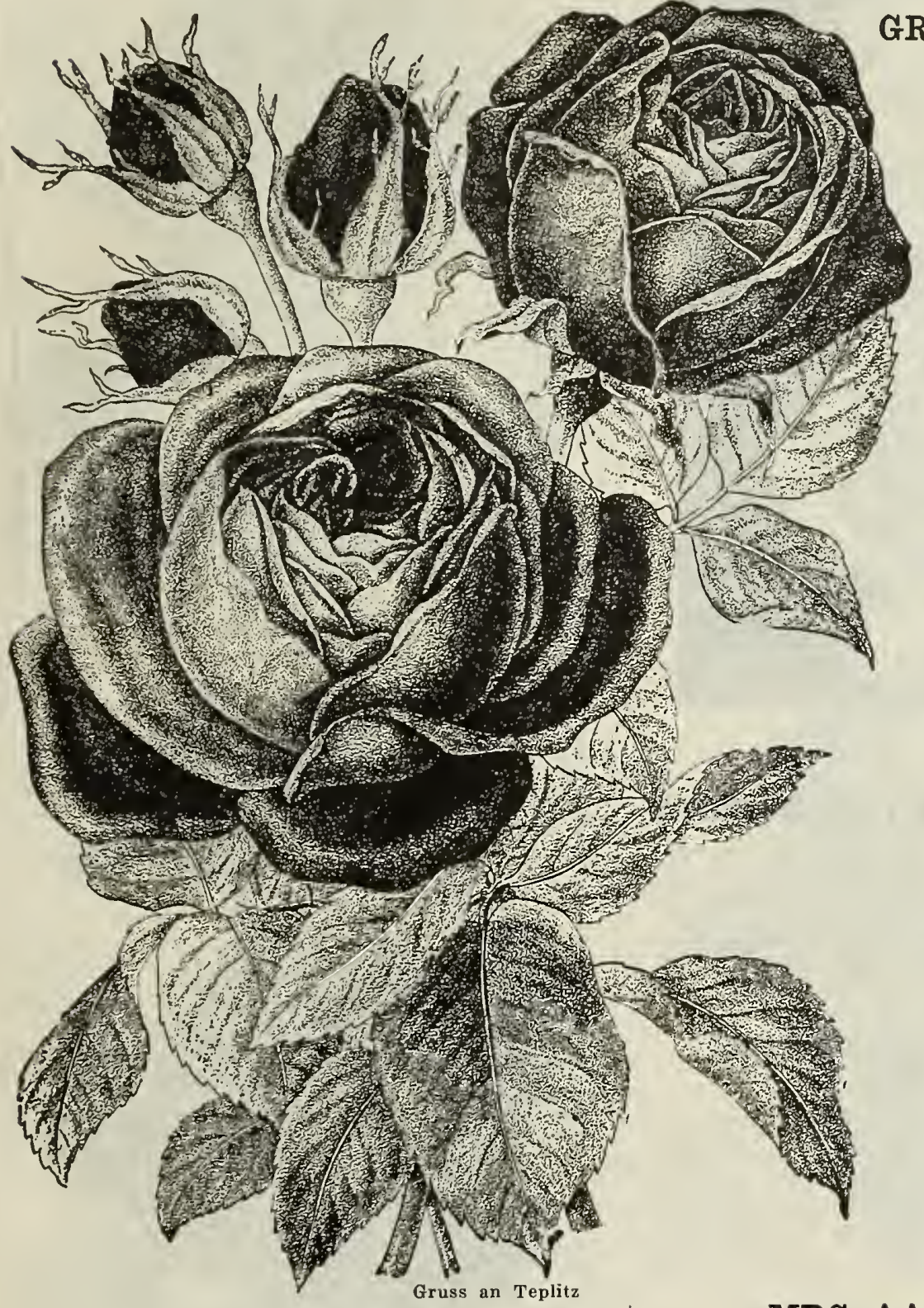

GRUSS AN TEPLITZ THE SWEETEST AND TCHEST CRIMSON ROSE

Called by some growers Virginia R. Coxe, The in.
tense, dazzling color of this Rose is found in no otler vawith a dark velvety sheen totally unlike any other color in the world any other color some, moderately double flowers Produced in most wonderful profusion throughout the whole growing season, in fact it is always in bloom. The flowers are produced singly, sometimes in clusters, produc ing a gorgeous effect on the lawn or in the garden all summer through. A wonderfully strong, vigorous grower, actually attaining a height of 4 to 5 feet, perfectly hardy everywhere. For fragrance there is no other Rose to com pare with it. Price, 10 cents each; two year old plants, 25 cents each.

\section{MADAME}

\section{SCHWALLER}

Has strong firm growth of the Hybrid Perpetuals, the same form and finish of flow. ers, being especially beautiful when full blown. It is very free in bloom, and has the fragrance of the old June Roses. Color is a bright rosy flesh, paler at the base of the petals and deepening on the edges. Apt to come in clusters, which are excollen for cutting. Price, 10 cents

\section{PAPA GONTIER}

Papa Gontier is a grand red Tea, of fine crimson shade and silken texture (as distinct from velvety texture). The bud is fine size and graceful form, and you would never suspect from it that the Rose is only semi-double. Extremely free, semi-double. Extremely free, both in growth and bloom leaved stems can be cut. One of the best, and a perfect bedder. Price, 10 cents each; large two year old plants, 30 cents each.

\section{METEOR}

An Old Favorite, Always in Demand

\section{MRS. AARON WARD}

This Rose is a real joy to the grower and absolutely distinct. One of the most delightful Roses of recent years in a color that catches the eye at once. Coppery orange in the open bud, golden orange when partly developed, pinkish fawn of lovely shade when fully open, when it looks like a full flufiy silk rosette. No wonder everybody that like a full hufiy silk rosette. Nrice, one year old plants, 20 cents each; two year old plants, 40 cents each.

Notwithstanding this famous old hardy favorite has long been grown, it still may be regarded as the most beautifully formed, brilliant velvety crimson variety now in cultivation. Beautiful buds and flowers, very large and exquisitely made. The bush' is remarkably vigorous in growth, perfectly hardy and constantly in bloom. Price, one year old plants, 15 cents each; two year old plants, 30 cents each.

\section{RENA ROBBINS}

A very strong grower, with splendid stems and immense globular flowers; color, white or lemon, with orange heart. We had hoped that this would prove a forcing variety, but it has developed, instead, fine bedding qualities, for which purpose we strongly recommend it. The bloom is of splendid size, and lovely, rounded form. Price, one year old plants, 20 cents each; two year old plants 40 cents each.

\section{PRESIDENT TAFT}

There have been two Roses sent out under this name a red variety from Europe without merit, and the one we here describe. This Rose was raised in Cincinnati, the home of President Taft. It is without question the most remarkable of all pink Roses. It has a shining, intense deep pink color possessed by no other Rose. It is a fine grower, free bloomer, good size and form, fragrant, and in a class by itself as to color. Mr. Frank Good, who is probably familiar with more Roses than any man in America, says: "Talk all you want to about the Rose President Taft, and then you will not say enough."' Price, one year old plants, 20 cents each; two jear old plants, 60 cents each. 


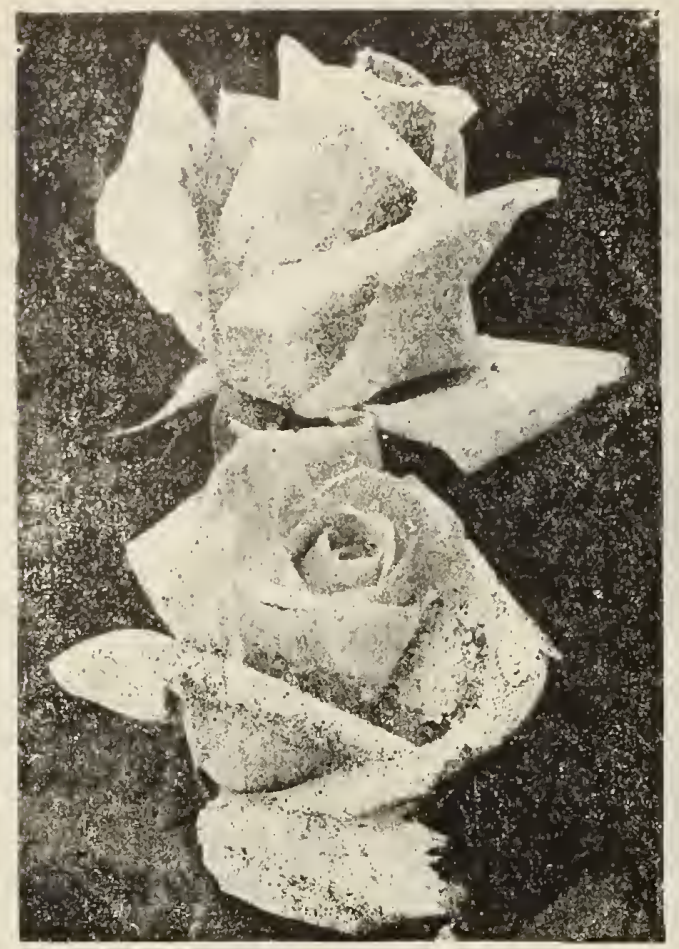

Molly Sharman-Crawford

\section{Mollie Sharman-Crawford}

We predict a great future for this grand snow white Rose; it is one of the freest branching and fastest grow. ing in the whole Rose family; has medium sized foliage, dark and heavy, with good, stiff, wiry stems and blooms dark and heavy, with good, stiff, wiry stems and blooms very pure, texture strong, it blooms freely and continuously; in all probability it will take first place as a white bedding and nurseryman's Rose. Price, 15 cents each; two year old plants, 40 cents each.

\section{SOUVENIR DE PIERRE NOTTING}

Marvelous beautiful flowers of the Maman Cochet type, very large and well filled, opening beautiful clear apricotyellow tinged with golden, mixed with orange yellow, edges of petals shaded carmine-rose. Truly a gorgeous effect. The bush is strong and upright in growth, with heavy canes, and bears a great profusion of these magnificent Roses all summer long. It can always be depended upon for a supply of cut-flowers. Price, one year old plants, 15 cents each; two year old plants, 35 cents each.

\section{MARIE VAN HOUTTE One of the Finest White Roses}

A most beautiful Tea Rose, a strong, sturdy grower, blooming constantly, with great freedom. The color of the flowers, which are full and double, is pale callary. yellow, passing to rich creamy white, shaded with pale rose. Well known and always popular. Price, one year old plants, 10 cents each; two year old plants, 30 cents each.

\section{ANTOINE RIVOIRE}

Will grow in almost any situation; strong and healthy. Always blooming. Flowers exquisite in form, large, double and fragrant: rosy flesh with yellow ground, shaded with border of carmine. The plant forms a big, vigorous bush, and is perfectly hardy in all climates. Good garden Rose. Price, one year old plants, 10 cents each; two year old plants, 30 cents each.

\section{BESSIE BROWN}

A Grand Hardy Rose, from Europe

Again we desire to call your attention to this magnifcent Rose, which maintains itself as one of the best that lias ever been introduccd into this country. It has un. surpassed beauty of a totally distinct character, bearing large, full, deep and double flowers, on strong, erect stems. The plants are hardy and vigorous, producing flowers profusely in the open ground all through the sum. mer. The color is almost pure white, though sometimes flushed with pink; petals large and of fine form. Price, one year old plants 15 cents each; two year old plants, 35 cents each.

\section{IVORY}

A Queen Among White Roses.

Golden Gate, known as the "White House liose," has long been one of our best Roses, not only for outdoor planting but for cutting under glass. This beautiful newcomer is an offspring and identical with its parent va. riety, Golden Gate, except in color, which is ivory-white. Buds are of elegant shape, long and pointerl; flowers full and double, frith and double, with substantial petals, sturdy in growth, free plants, 10 cents each; two year old plants 30 cents each.

\section{GOLDEN GATE}

This maguificent Rose has been freely used in the decorations at the White House; hence it is often called "The White House Rose." Color, rich, creamy white, shaded witl golden yellow and clear rose of indescrib. able beauty. It is immense in size, finely formed, with long and beautiful buds. Price, one year old plants, 10 cents each; two year old plants, 30 cents each.

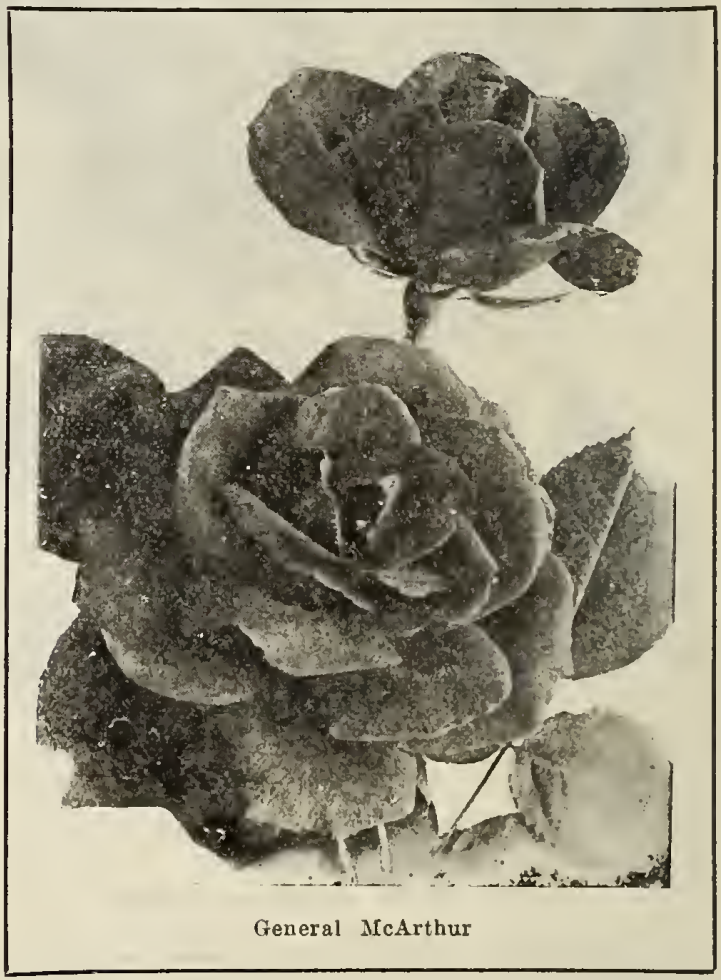

\section{General McArthur}

\section{Great New Scarlet Rose}

One of the best and most vivid crimson-scarlet Roses in cultivation; does splendidly everywhere; a great Rose in the open ground. strong, healthy, hardy and vigorous, always blooming; flowers exquisitely fragrant. A great favorite. Price, one year old plants, 15 cents each; two year old plants, 40 cents each. 


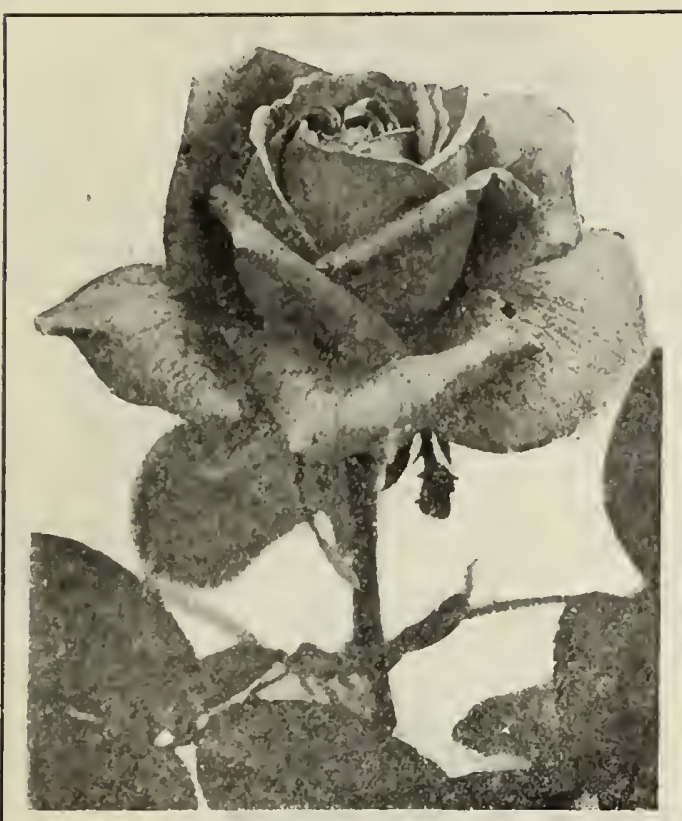

Alice Rooserelt

\section{ALICE ROOSEVELT}

An Improved Mme. Chatenay.

A rare and very beautiful Rose of novel and distinct color. ricb pink or rose flushed with orange and fawn. Flowers large, well filled and very fragrant. $\Lambda$ strong healtby grower and free bloomer; quite hardy and fine for the yard or garden. Price, 15 cents each; two year old plants, 35 cents each.

\section{HECTOR MACKENZIE}

Deep pink, cbanging to silvery crimson; flowera large and full, of perfect globular form; botb free and frarant. Strong and vigorous and very free branching. Price, 15 cents each; two year old plants, 35 cents each.

\section{PAULA}

A vigorous, free Tea Rose, most deliciously fragrant hsbit erect, buds well shaped, sulphur yellow witb ochre center; like a better Etoile.de Lyon. Price, $\mathbf{1 5}$ cents each; two year old plants, 35 cents each.

\section{MME. CONSTANT SOUPERT}

This is one of the most valuable Roses that has been sent out in recent years. Tbe growth is vigorous and the flowers large and very full, perfect form, color lssting a long time in perfection. Citron yellow, shaded with rosy peach; plump, pointed buds of great size. The parentage, Maman Cochet and Marechal Niel, a sufficent guarantee of roval blood. Price, 20 cents each; two year old plants, 50 cents each.

\section{LADY BATTERSEA}

This rariety has long ovsl buds, sharply pointed, very striking in form: the color is bright cherry crimson; the stems are stiff and extremely long for a red Rose: a vigor. ous grower; not very full, but an unusually showy variety; the only red Rose approaching Niphetos in form; color brilliant and unusual. Price, 10 cents each; large two year old plants, 35 cents each.

\section{HELENA CAMBIER}

A variety of unusual beauty, with very double flowers of medium size. The colors are vsrying, ranging from salmon-rose to coppery rose, very often a handsome aaf fron huf. As the flowers expand, the color becomes limhter. A most remarkable sort in every respect. Price, 15 cents each; two year old plants, 40 cents each.

\section{MRS. DAVID JARDINE}

A Great Exhlbition Garden Rose.

It is not given to many Roses to possess the two valuable characteristics such as Mra. Jardine does in being one of the greatest pink Hybrid Tea Roses for forcing under glasa, as wcll as a garden busl Rose of the first water. The blooms are large, of perfect form and produced on shade of bright, rosy pink, shading on the outer petals to aalmon-pink. Price, 15 cents each; two year old piants, 40 cents each.

\section{MLLE. FRANCISKA KRUGER}

A favorite Rose for the garden and the most satiafactory variety in its color. The coloring ia strikingly hand some, a blending of deep yellow with coppery yellow and buff shadinga. Fine buds and splendid flowers which remain in good condition a long time. Price, 10 cents each: two year old plants, 30 cents each.

\section{BLUMENSCHMIDT}

This is undoubtedly the best Pure Yellow Rose for garden planting yet introduced; color is clear bright golden yellow; the plant ia a atrong, robust grower and ver hardy; makes beautiful buds and is very double and sweet, and one of the very best. A sport from Mademoi selle Franciska Kruger. We believe it to be the only good yellow bedding Rose up to date. You had better try some of this, as unquestionably it has a great future. Price, 15 cents each; two year old plants, 30 cents each

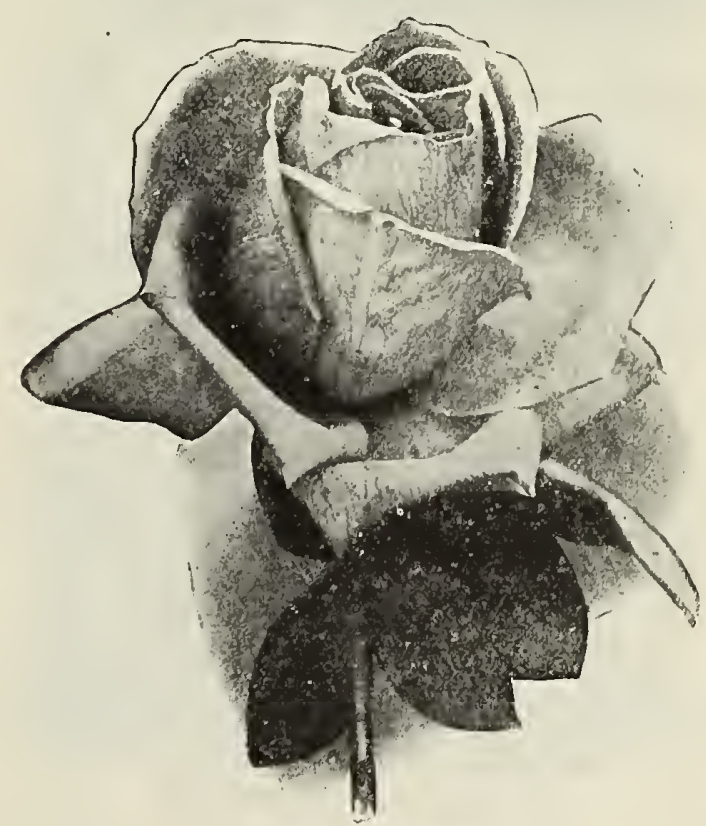

Col. R. S. Williamson

\section{COL. R. S. WILLIAMSON}

Satin white with deep blush center; blooms very large, full, of perfect form, with higb pointed center; canes rigid and freely produced petals round snd of great sub. stance. A grand Rose for any purpose. Price, 15 cents each; two year old plants, 35 cents each.

\section{WELLESLEY}

This grand, hardy Everblooming Rose, a seedling of "Liberty" crossed witb "Bridesmaid," retaina tbe form of "Liberty" with the fullneas of "Bridesmaid ". and in color is a beautiful sbade of pink, the outside of the petals being bright and clear, with a silvery reverse. It is a very vigorous, healthy grower, carrying tbe flowers on long, atiff stems. Remarkably free flowering and tine keeping qualities. Price, 15 cents each; two jear old plants, 40 cents each. 


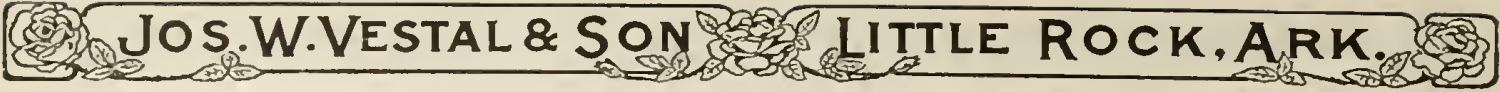

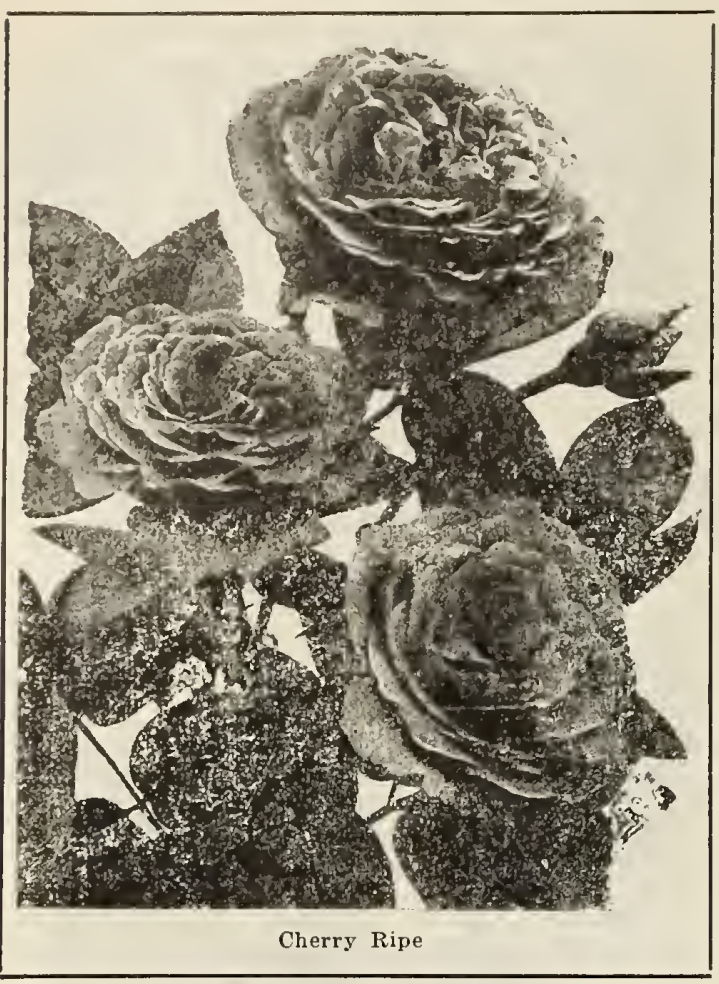

\section{CHERRY RIPE}

One of the brightest, vivid crimson scarlet Roses in existence of free branching habit of growth; very vigorous and healthy. Every shoot produces a large, double, well-formed flower, which, combined with its fra grance and hardiness, makes this essentially one of the greatest red Roses for out door planting. The more we grow this Rose the better we like it. Price, 15 cents each; two year old plants, 40 cents each.

\section{KILLARNEY}

Fo other Rose has attracted so much attention as Kil. Iarney. It has proved a most valuable Rose wherever tried. It is a strong robust grower and free and con. tinuous bloomer. The color is brilliant sparkling pink the flowers are extra large and full, with broad, thick petals and delightful tea fragrance. Price, 15 cents each; two year old plants, 40 cents each.

\section{WHITE KILLARNEY}

A pure white sport from Killarney. Identical with the ever-popular and well known pink Killarney. A strong robust grower, flowering very freely throughout the sea. son. The flowers are very large, buds long and pointed; erect stems and a great acquisition. Price, 20 cents each: two year old plants, 50 cents each.

\section{MARION DINGEE}

The flowers are large, beautifully cup shaped, moderate ly full, and borne in wonderful profusion all through the growing season; in fact we scarcely know of any other Rose that will produce so many perfect flowers in a given time. It is a deep brilliant crimson, one of the darkest and richest colored tes Roses in existence. Price, 10 cents each; large plants, 30 cents each.

\section{SOUVENIR MALMAISON}

This Rose has been the one standard roriety in Rose gardens for the past thirty years; and in fact there is not a Rose extant that rivals it for general cultivation. Its rich, flesh colored flowers are of immense size, double to the center, are produced in abundance, and have exquisito

\section{CHAMPION OF THE WORLD}

This is in all around good qualities the greatest Ever blooming Rose in cultivation. Plants which have bloomed all the summer in the garden may be potted in the autumn. and they will immediately start new growth and bloom profusely all winter. The blossoms are perfectly double to the center, and of the most perfcet shape, both in bud and blossom, while its color is a rich, deep rosy pink. Price, 10 cents each; large size, 30 cents each.

\section{ETOILE DE LYON}

This magnificent Tea Rose is a rich golden yellow : strong, healthy and vigorous grower immense bloomer bearing flowers and buds early and late. The flowers are very deep, rich and full, excellent substance, very sweet. Surely one of the best and most beautiful yellow Tea Roses for general planting ever introduced. Remarkably hardy, both as to heat and cold, frequently standing the winters here uninjured in open ground without protection, and blooming nicely all through the hottest part of the summer. Price, 15 cents each; large two year old plants, 30 cents each.

\section{SAFRANO}

This is a splendid old time Rose that has not bcen superseded by any ncwcomer of its class or color. It is a variety of great value, particularly for outdoor planting. It grows vigorously and has the vitality necessery to produce a continuous crop of flowers from early summer until late in the autumn; quite hardy. It is valued very highly for its beautiful buds and handsome flowers. The color is bright apricot yellow, changing to orange and fawn, sometimes tinted with rose. Very fragrant. Price, 10 cents each; two year old plants, 30 cents each.

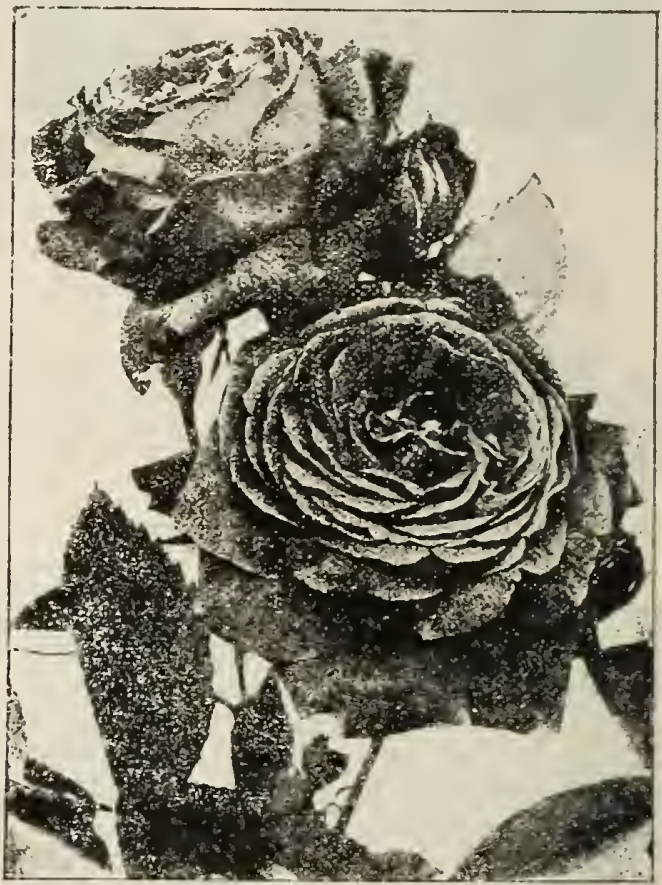

Helen Gould

\section{HELEN GOULD}

It has proven itself to be the strongest growing freest bloming largest flowering and hardiest Rose in existence. It is a better Rose for general planting than American Beauty-the dream and hope of every Rose grower for years past. It is a strong, dwarf, compact grower, abso. lutely free from disease of all kind, young plants bloom. ing continuously throughout the year. The flowers are 85 large as the American Beauty, and are full and perfectly double; the buds beautifully made, long and pointed, produced on Iong, stiff, erect stems, The color is \& warm rosy crimson. the color of a ripe watermelon. Price, 15 cents each; large plants, 40 cents each.

\section{MAD. DE WATTEVILLE}

This grand variety, sometimes called the Tulip Rose, is one of the most beautiful varieties. The color is a re. rosy blush: the petals are large and each one widely bordered with brimht crimson, which gires it \& very strik. ing and beautiful appearance. Flowers are large, very full and highly perfumed. For planting in open ground this Rose takes front rank. Price, 15 cents each; large. size, 30 cents eqch. 


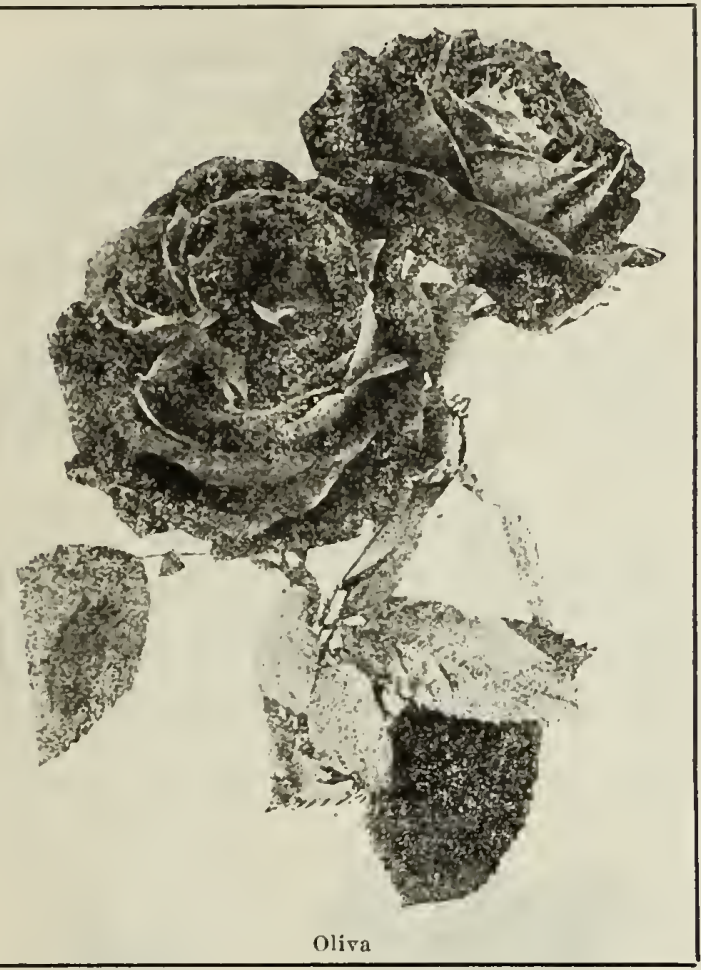

\section{OLIVA}

A seedling of Gen. McArthur and Helen Gould. Oliva shows the rapid, strong growing and free blooming quali. ties of McArthur, while in shape of flower and color it strongly resembles Helen Gould. Buds are nicely pointed - like La France-and very fully double. Deep rose color, one of the finest in cultivation. Price, 20 cents each; two year old plants, 40 cents each.

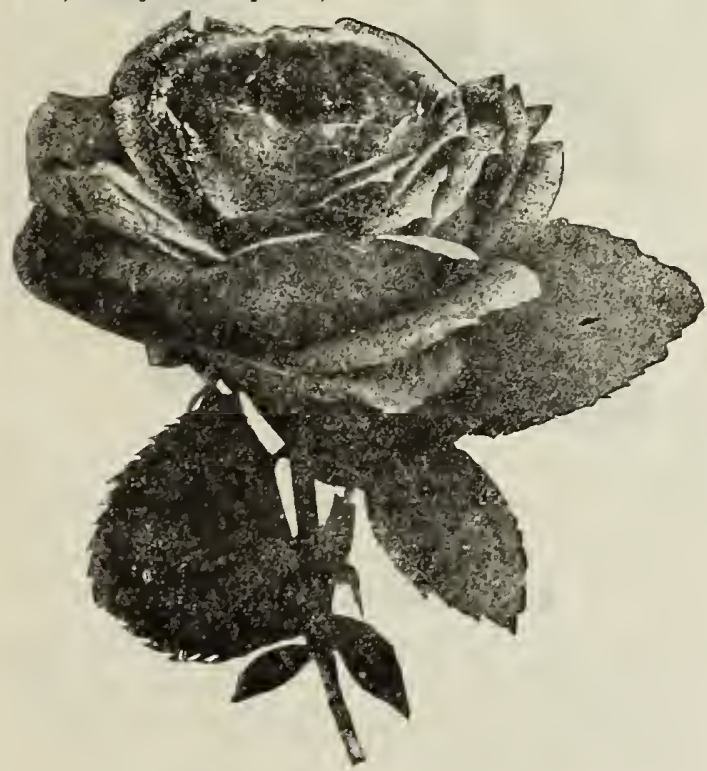

Christine De Noue

\section{CHRISTIAN DE NOUE}

This beautiful new Tea Rose is a very charming Rose, and is particularly valuable because red has been rery scarce color among Tea Roses, and this one seems excep. tionally fine. It is a splendid grower, making a laige sized graceful bush, with bright, deep green foliage; a constant and very free bloomer; the flowers are well borne upon strong stems, and are usually large and handsome; the buds are long and finely pointed and the color is a clear, rich maroon, or deep purplish red, passing to lake. center sometimes streaked with silvery white. Price, 10 cents each; two year old plants, 35 cents each.

\section{COUNTESS ANNA THUN}

It is of immense size, and of the most lovely and perfect form imaginable. Color, a beautiful citron yellow, with coppery and peach center, shading to orange salmon and silvery pink

\section{THE QUEEN}

It is a very large, pure snow white, Everblooming Rose the flowers are extremely large, very full and double, and delightfully perfumed; a vigorous and healthy grower. It is considercd by all who have tricd it one of the most valuable pure white Roses for all purposes. Price, 10 cents each; two year old plants 30 cents each.

\section{PERNET'S TRIUMPH}

The flowers are extra large, having broad, thick petals and long tapering buds, with delicious fragrance. Color a fine clear magnet red, sometimes passing to bright crimson. The flowers retain their beauty for a long time. Price, 15 cents each; two year old plants, 30 cents each.

\section{PRINCESS VENOSA}

A quick free, healthy grower; blooms early and through out the season gives unbroken continuity of lovely flowers. Flowers in great abundance; large, finely formed, free and double. A lorely combination of deep rose and yellow shades. Price, 15 cents each; large two year old plants, 40 cents each.

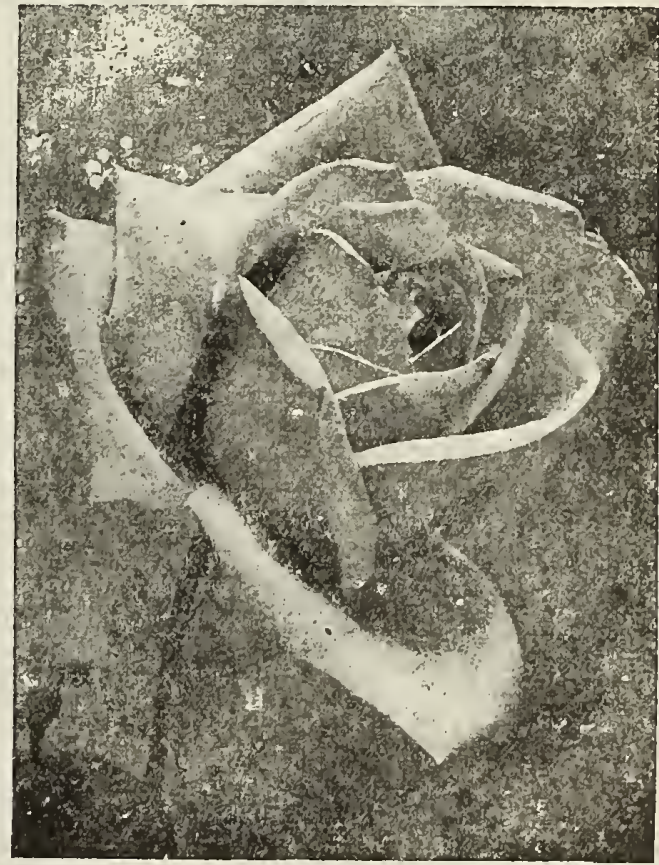

Winnie Davis

\section{WINNIE DAVIS}

One of the finest colored Roses. In small bud it is reddish pink; when unfolding it is a yellowish pink, running to salmon, the inside of petals creamy white; when fully open resembling a sunburst, something not found in any other Rose. It is of large size, very double and full. This grand Rose is a cross between the famous Kaiserin Aurusta Victoria and Belle Seibrecht Price, young plants, 15 cents each; strong two year old plants, 40 cents each.

\section{FRANCO-RUSSIA}

A new Rose of exquisite kind and color, ranked by many enthusiasts as the best jellow Tea Rose. The flowers are of large size, perfectly double to the center and perfect in shape both in bud and blossoms. The color is mag nificent-deep rich lemon yellow, with creamy yellow center with tints of sulphur. It is beautiful beyond descrip. tion. A strong, healthy grower, and one of the grand est Roses in this book. Price, 15 cents each; two year old Roses in this book. 


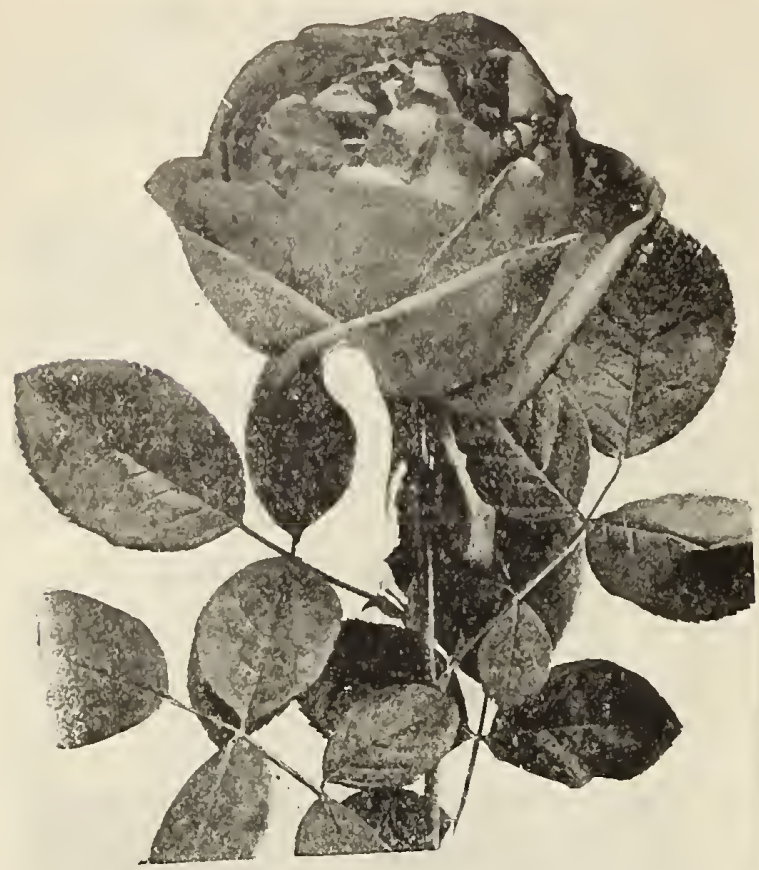

Freiherr Von Marschall

\section{Freiherr Von Marschall}

A magnificent new Rose, with the most beautiful foliage we have ever seen. Flowers are large, beautifully shaped, double and full. Bright red. This is one of the brightest if not the very best red Tea Rose in existence. Fine, long, well shaped buds. As an outdoor Rose it has no superior. Price, 15 cents each; two year old plants, 35 cents each.

\section{PRESIDENT CARNOT}

It is a Rose of the largest size, beautiful both in bud and open flower. The buds come on long, stiff stems, in clusters of from six to twelve. Each individual flower stands out distinct on its stem. No crowding as in the case of so many Roses that bloom in clusters. The color is distinct and novel, a lovely fawn, shading to pearl. It often measures five to six inches in diameter. We have no hesitancy in saying that this charming Rose will become as popular as La France, as it has all the good qualities of that Rose and at same time is so distinct that it at tracts immediate attention. It is, indeed, wonderful Rose-one that everybody can grow and bloom. Price, fine young, strong plants, 15 cents each; fine two year old plants, 40 cents each.

\section{ROSE GUBERT}

Color, canary yellow, deepening at the center; bud long, producing a large flower. Extremely free in growth and bloom. Price, 15 cents each; two year old plants, 35 cents each.

\section{SNOW FLAKE}

Pure 'Tea, but a foreign seedling; the freest flowering white Rose we have seen. It is especially useful in set designs. For a pot plant it cannot be excelled. We counted on one plant 143 buds and flowers in a single day. Nice young plants, 10 cents each; large plants, 30 cents each.

\section{MADAM MARGOTTIN}

A famous Rose. Flowers very large. Full and double, borne profusely. Color, dark citron-yellow, bright red center. A strong grower and a remarkably fine Rose in every way. Price, 10 cents each; two year old plants, 30 cents each.

\section{AGRIPPINA}

Rich, beautiful crimson. Ideal for bedding purposes. $O$ ? branching habit and produces an abundance of bloom. Price, 10 cents each; two year old plants, 30 cents each.

\section{MAD. DE VATRY}

It makes big clesn buds of great beauty and opens well, showing the large, full double flowers to great advantage. The color is a rich red, changing to a silvery peachThinds one of the delicate hues seen on the inside of the fairest deep-sea shells-rosy flesh, bathed in golden amber, broad, shell-like petals, bright and beautiful; in every way a fine Rose. Price, 10 cents each; two year old plants, 30 cents each.

\section{UNCLE JOHNN}

A glorious rariety which was too long in partial obcurity, but which hes recently attracted wide attention and is now very popular. It is a monthly everblooming sort, strong growing, and used extensively for winter forcing. Color, creamy yellow, with pink edges. Price, 15 cents each; two year old plants, 35 cents each.

\section{CORNELIA COOK}

The buds are most besutiful, of immense size and are borne up high on msssive stems, and with their round, full, heavy form, carry an air of grace and dignity quite unusual. The flowers are the clearest, snowiest white and are arranged in the most faultless and symmetrical manner. Cornelia Cook has the largest bud of any white Rose. Price, 10 cents each; large two year old plants, 40 cents each.

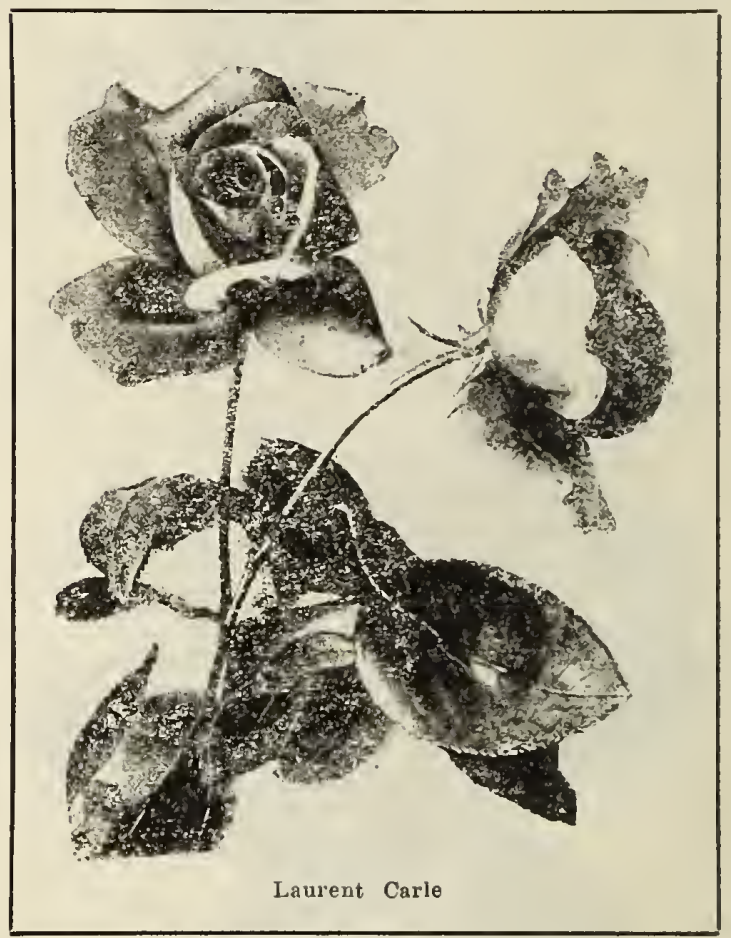

\section{Laurent Carle}

An extremely vigorous grower of erect branching habit and fine dark green foliage; long buds borne on lon stems, opening into large flowers of perfect form, just full enough' to open freely; color, brilliant velvety carmine; a very promisıng variety. Price, 15 cents each; two year old plants, 40 cents each.
Try Our Trial Collection of Evorblooming

TWENTY CHOICE VARIETIES

VERY FINE PLANTS. BEST SORTS 


\section{MME. CECILE BERTHOD}

Deep golden yellow Rose. Most beautiful, both in bud and flower, which is deep golden yellow. In fact, the deepest yellow in color of any rose we grow. The foliage is very Color. Price, 15 cents each; two year old plants, 35 cents Color.

\section{MADAME JOSEPH SCHWARTZ}

A lovely Teß Rose; extra large globular flowers, very full and sweet; pure white, tinged and shaded with palc yellow and rosy blush. Pilce, 10 cents each; large plants, 25 cents each.

\section{DEVONIENSIS}

The charming Magnolia Rose. We doubt if there is scarcely anyone who does not know of the beauty of this frmous old favorite. When planted outdoors, it gives ram all through the sea. an abundance of its beautiful fowcrs all through the sea. ters; large, very full and double, and deliciously scented. Price, 15 cents each; large plants, 35 cents each.

\section{MRS. E. DURANTH}

This Rose is very beautiful, its strong branching habit being admirable; each side shoot brings a perfect flower on a stif stem; nerer shows a weak neck. The upper surface of each petal is shell pink, the reverse, soft rose: very free and fragrant. Price, 10 cents each; two year old plants, 30 cents each.

\section{DUCHESS DE BRABANT}

Or Comtesse de la Barthe. Combines exquisite perfume, beautiful coloring and a matchless profusion of flowers and foliage. Soft, light rose, with heary shading of amber and salmon. Quite hardy. Price, 10 cents each; large plants, 25 cents each.

\section{MADAM WELCHE}

Color beautiful amber yellow, deepening towards the center to orange or coppery yellow, delicately tinged and shaded with ruddy crimson; flowers extra large fine globular form very double and full. Price, 15 cents each; two year old plants, 35 cents each.

\section{WHITE BOUGERE}

A frce bloomer, and clean, healthy erower; blooms of great substance; pure white; good stiff stem; as pure a white as Niphetos and will produce 50 per cent more blooms than Bride. Price, 10 cents each; large plants, 25 cents each.

\section{PINK BOUGERE}

\section{A Grand Garden Rose}

Anyone who has seen this grand old sort growing in the open ground will agree that it deserves the highest word of praise we can give it, having been introduced in 1832 Since then it has been tried and found to be of rare value for general planting. The flowers are unusually large decp, full and double. They are supported on long, stiff stems, and are produced in bountiful abundance throughout the growing season. In color they are bronze rose or violet crinison, delicately shaded with lilac. Exceedingly sweet; remarliably haxdy. Price, 10 cents each; two year old plants, 30 cents each.

\section{MLLE. JEAN DUPUY}

Long pointed bud, nicely rounded flower, large and full color, golden yellow passing to reddish orange, petal bordered with rose; very large, full bloom and fragrant. A magnificent grower with excellent foliage. Price, 15 cents each; two year old plants, 35 cents each.

\section{HERMOSA}

Everybody knows this famous variety. As hardy as an oak, and always corered with clear pink blooms. There is not a shade of color of any kind to mar its purity. We doubt if any Rose ever grown will take its place. Price, 15 cents each; large two year old plants, 30 cents each.

\section{CATHERINE MERMET}

One of the best varieties of Tea Roses. A very free bloomer, producing clear, shining pink flowers, the center being shaded with fawn and amber. Is a good Rose for open-ground culture and forcing under glass. Price, one year old plants, 10 cents each; two year old plants, $\mathbf{3 0}$ cents each.

\section{MISS KATE MOULTON}

Light pink, very beautiful; habit robust, with heavy foliage, making it a grand Rose for outdoor culture; equally good for forcing by reason of its free-blooming qualities. Price, one year old plants, 15 cents each; two year old plants, 35 cents each.

\section{MARIE LAMBERT}

A lovely white rose; pure Tea, but a foreign seedling the freest flowering white rose we have seen. It will be especially useful in set designs. For a pot plant it cannot be excelled, as it possesses every quality of a pot rose. We counted on one plant 143 buds and flowers in a single day. Nice young plants, 10 cents each; large plants, 30 cents each.

\section{TWO YEAR OLD ROSES}

The demand for our Two Year Old Roses is constantly increasing and we are fully prepared this season with an extra fine stock of choicest varieties, which will be found fully described elsewhere in this Catalogue. These Two Year Old Roses are so large that they cannot be sent by mail, but must go by express, and the purchaser pays the express charges; but we are careful to pack as light as the safety of the plants will permit. and always add as many extras as we can afford to help pay the charges. All our express shipments are billed through at the special 20 per cent reduction allowed on plants, so that the charges are now very reasonable.

Two Year Old Roses weigh when packed about as follows: 12 plants, 20 pounds; 25 plants, 35 pounds: 50 plants, 50 pounds; 100 plants, 75 pounds. This includes the earth left on roots, which is quite necessary to Roses of this size; if all the earth is shaken off the plants may be hard to start and slow to bloom, and this is one reason why Two Year Old Roses should always be sent by express.

\section{SPECIAL BARGAINS IN TWO YEAR OLD ROSES}

Persons who will leave the selection of varieties to us, we will make up choice collections same as if for our. selves, and guarantee to please; all correctly labeled, packed and delivered to express here as follows:

12 CHOICE VARTETIES, 1 EACH, PRICE

.82 .50

25 CHOICE VARIETIES, 1 EACH, PRIOE.

4.50

50 TWO YEAR OLD EVERBLOOMING ROSES, $2 ;$ BEST KINDS, 2 EACH..

8.50

100 TWO YEAR OLD EVERBLOOMTNG EOSES, 25 BEST KINDS, 4 EACH

16.00

PLEASE NOTICE. All our Two Year Old Roses are in pots, on their own roots, and are fine thrifty plants, 12 to 20 inches high, ready for immediate bloom.

IMPORTANT. Owing to our knowledge of varieties, we can usually make a better selection for our customers than they themselres could make. Where the selection is left to us, we shall send the very best sorts, those that we think will give the best results in the locality where they are to be planted. We shall be glad to know, however, if the pur. chaser has any preference as to varieties, in which case the kinds selected will, if possible, be included. 


\section{Hardy Hybrid Perpetual Roses}

ALL CF IRONCLAD HARDINESS. FOR PERMANENT OUTDOOR PLANTING. SELECTED FOR THOSE WHO WANT ROSES THAT WILL STAND THE SEVEREST OLIMATE AND GIVE SATISFACTION IN BLOSSOMS.

This class is considered the most valuable of all Roses, beeause they bear the largest, sweetest and most brilliant colored flowers, and are so liardy and vigorous they live over winter without protection and continue to bloom regularly from year to year. fome do not bloom until the sceond year, but after beeoming established, will bloom freely during the summer and autumn months.

Thougl called perpetual, it lerpctuals you may be quite eertain of laving Roses every year without further trouble. Roses. The perpetual, it must be understood that they are not such early and constant bloomers as the Ever.Blooming (1ybrid Perpetual sliould not be ordered for house culture, as they are not suitable for that purpose. D. not become inpatient if your plantings of these do not bloom the first season. Give them a chance to beeome established. Wese Roses are especially suited to plant in all the Northern States; also in the colder parts of the States of Virginia.

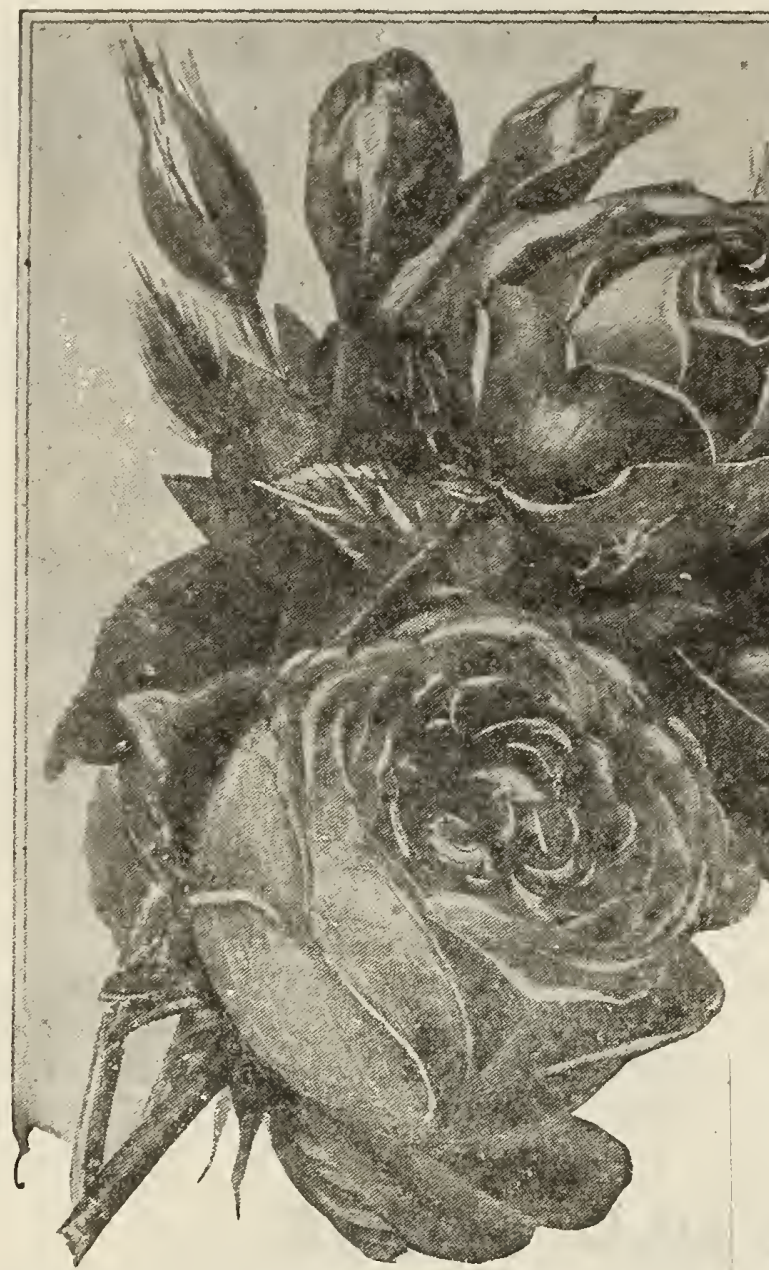

Gloire De Margottin

\section{GLOIRE DE MARGOTTIN}

In this grand Rose the fiowers are very large and of symmetrical form, somewhat globular very full and deliciously scented. The color is a clear, dazzling red. Certainly one of the most brilliant Rnses ever seen. It is a free bloomer and vigorous grower, and is recommended for great beauty and wonderful colnr. Price, 15 cents each; two year old plants, 35 cents each.

\section{GENERAL JACQUEMINOT}

A rieh velvety crimson, changing to scarlet crimson. This is the best known of all Hybrid Perpetuals, and is without a rival in fragrance and richness of color. Price, 10 cents each; two year old plants, 35 cents each.

\section{MAGNA CHARTA}

Extra large, full flowers, very double; of fine form and sweet; eolor clear rosy red, beautifully flushed with violet crimson. A sure and profuse bloomer; one of the hardiest and best for general planting. Large light green foliage; flowers very fracrant. Price, 15 cents each; two year old plants, 35 cents each.

\section{BALL OF SiNOW}

Pure snowy-white, sometimes faintly tinged with pale rose, flowers medium size. full and fragrant, bloons the first vear all the season. Price, 15 cents each; two year old plants, 35 cents each.

\section{CLIO}

Flowers rery large, color flesh, shaded in center to rosy-pink. Its perfect hardi. ness, vigorous growth and freedom of bloom make it most valuable for planting in the Rose garden, while the large size, exquisite color and delicious fragranee of its flowers - which at perfection are as large as Peonies make it desirable as a cut-flower Rose. Price, one year old plants, 15 cents each; two year old plants, 35 cents each.

\section{CAPTAIN HAYWARD}

The strongest grower, the freest bloomer, the riehest eolored, the handsomest shaped of all red $\mathrm{Hy}$. brid Perpetual Roses. Color, richest crimson-scarlet; both bud and flower are perfeet. Price, one year old plants, 15 cents each; two year old plants, 35 cents each.

CAPTAIN CHRISTY

The flowers are of magnificent form, and very double. The color is a fresh, delicate pink; with deeper shad. ings in the center of the flower, the whole floter possessing a bright, satiny appearance. A most desirable variety. It is a free bloomer. Price, 15 cents each; two year old plants, 35 cents each.

\section{GIANT OF BATTLES}

In this hardy Rose the color is a most intense glowing ed; makes the curling velvety petals fascinating beynnd description. The flowers are very large, perfectly double. Priee, 15 cents each; two year old plants, 30 cents each.

\section{PAUL NEYRON}

Deep shining rose rery fresh aud prettw. flowers rery arge, often measuring five inches in diameter. Without doubt the largest flower of all Roses, and it has this merit-the buds always develnp flne perfeet Roses. Price, 15 cents each; two year old plants, 35 cents each.

\section{PRINCE CAMITLE DE ROHAN The Black Rose}

This is a magnificent Rose, celebrated the world over for its large, handsome fragrant flowers. and the freedom with whieh they are produced. The eolor is a deep, rich velvety crimson, passing to intense maroon, shaded black: at a short distane they appear really black. It is the nearest black. Price, 15 cents each; two year old plants, 35 cents each.

\section{ULRICH BRUNNER}

Splendid upright grower, with brigltt, healthy foliage. The flowers are good size and of fine form, with shellshaped petals. One of the most abundant bloomers; color cherry red. Price, 15 cents each; two year old plants, 35 cents each.

\section{MRS. JOHN LAING}

Color a clear, bright shell-pink, exquisitely shaded; the buds are long and pointed, the flowers extra large and full; borne on long stems and exeeedinlgy sweet; valuable both for open ground and greenhouse culture Price, 15 cents each; two year old plants, 35 cents each. 


\section{Polyantha or Baby Rambler Roses \\ NEWER VARIETIES}

A Class of Minlature Roses derlved from the Climbing Polyantha. They are of dwarf habit and bloom so freely as to cover the entile plant with bloom. The plants are splendid for bedding, or as edgings for borders they are hardy

\section{JESSIE}

This is a charming novelty, is constantly in bloom, commencing with the first June Roses and continuing until frost kills them off in November and December. The height outside does not exceed two and one-half feet. It has a freely branching habit, the foliage is briglit, glossy green and wonderfully free from mildew. The flower: borne are in huge clusters and are of a bright cherry crimson color, which does not fade or develop the objectionable purple or magenta tints. Price, 15 cents each two year old plants, 35 cents each.

\section{MRS. TAFT}

An improvement on Baby Rambler, a brighter shade of color, a continuous bloomer in large clusters from sprin till frost. A beautiful running mate for Orleans Rose making a shapely and beautiful plant that is a boquet of the very richest shade of crimsnn. Price, 15 cents each; two year old plants, 35 cents each.

\section{RED BABY RAMBLER}

\section{Madame Norbert Levavasseur.}

This is the original Baby Rambler, daddy of them all. One of the best hardy bedding Roses in existence. The plants are very vigorous and grow 18 to 24 inches. The folinge is dark, glossy green and remarkably free from insects and fungus. The flowers are borne clusters of 20,30 or more to the clnster; in every way resembling the blossoms of the Climbing Crimson Rambler. It is perfectly hardy and blooms all the time indoors, and from May to November ontdoors. Splendid for making a border. Price, one year old plants, 15 cents each; two year old plants, 40 cents each.

\section{PINK BABY RAMBLER}

\section{Orleans Rose}

The showiest and prettiest of the pink "Baby" Roses this charming and dainty little variety is of beautifully rounded habit and is a huge boquet of brilliant bloom deep cerise with showy center of pure white, florets not crowded, but of beautiful arrangement. The color is irresistible, the plant grows like a weed, and the flowers are nearly "immortelle" in their lasting quality; we believe that they will outlast almost any other Rose in existence. with their stiff, paper-like texture. Price, 20 cents each; two year old plants, 50 cents each.

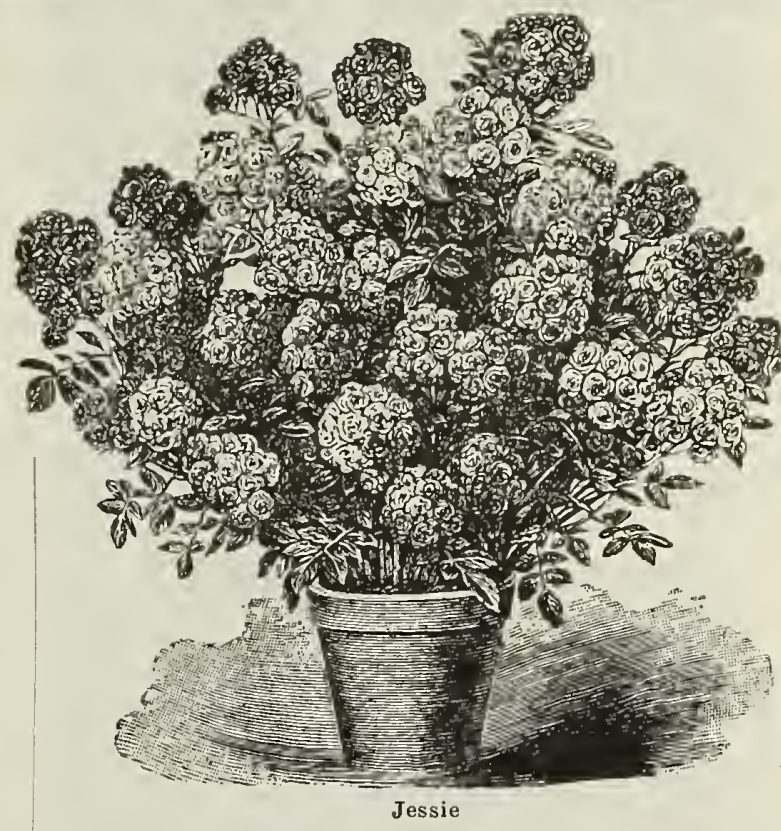

CATHERINE ZEIMET White Baby Rambler

This is surely a beauty. It grows to a height of 15 to 20 inches, and produces double, pure white flowers in wonderful abundance. It has a fragrance similar to Hya cinths. Of free, compact growth and very attractive, sheet of white and always in bloom. Price, 15 conts each; two year old plants, 35 cents each.

SPECIAI NOTICE. Plant liberally of Baby Ramble Roses Superb for massing bedding borders and single specimens. Never out of bloom and for striking effect specimens. Never out of bloom and for striking effect
are unsurpassed. The Crimson and Pink Baby Ramblers are really gorgeous.

\section{OUR POPULAR SOUPERT COLLECTION}

FREE BLOOMERS-QUEEN OF ALL BEDDING ROSES-THE THREE FOR 25 CENTS.

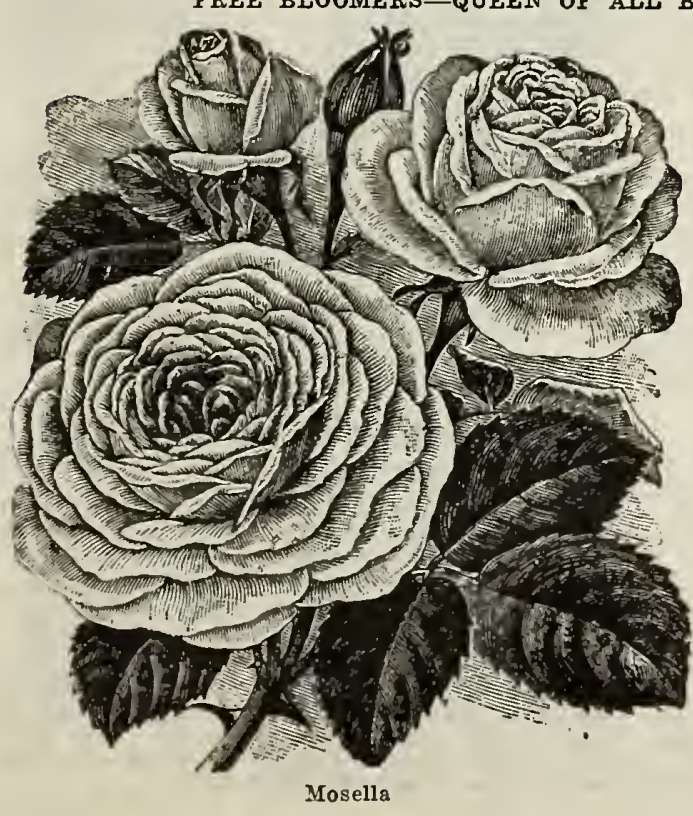

\section{CLOTHILDE SOUPERT}

This grand Rose continues to be one of the best and most beautiful varieties for bedding ever introduced. Flowers are deliciously sweet; color beautiful creamywhite, tinged with amber. Price, 10 cents each; two year old plants, 30 cents each.

\section{YELLOW SOUPERT OR MOSELLA}

Color is chrome-yellow in the center, getting creamywhite on the edges of the petals. Price 15 cents each two year old plants, 35 cents each.

\section{MLLE. CECILE BRUNER}

Rosy pink on rich creamy white ground; a great bloomer; very satisfactory for bedding. Prico, 15 cents each; large plants, 35 cents each.

\section{PLANTS ARE NOT DELIVERED FREE BY EXPRESS}

In all cases the buyer must pay the carrying charges. We deliver plants free by mail, if so ordered, and it is practicable; but we have to take the soil from the roots to lighten, and must send smaller plants than if sent by express: We always add extra plants to help defray express charges. 


\section{Beautiful Climbing Roses}

There has been a remarkable revival of interest in this class of Roses during the past few years and many new and rare kinds recently introduced have added greatly to the interest in them. We make a specialty of the Climbing Roses because their remarkable merits entitle them to a place in every garden. There are few Roses that are as good and none that are more satisfactory.

All these Roses arc strong growers, and most of them are hardy everwhere with slight protection. they bloom with the greatest freedom, and many of them are blooming every day during the growing scason. Their flowers are most beautiful-beyond the power of words to de scribe.

It is difficult to say whicl of these Roses are the toscription will do justice to such rarieties as Climbing Clothilde Soupert, Mrs. Rob. ert Peary, Climbing Wootton, Climbing Meteor, Climbing Bridesmaid and the Rambler Roses of all the Rose that we offer, we fine that the climbing kinds are among the cheapest, best and most. satisfactory for general plant.

\section{MRS. ROBERT PEARY}

\section{(Or Climbing Kaiserin Augusta Victoria.)}

The first white hardy everblooming climbing Rose. It an offspring of that grand variety, the best pure white hardy everblooming Rose, Kaiserin Augusta Victoria. The flowers are something grand ther are the equal of the finest and most beautiful cut flower Roses: of splen. did substance: extra large, full, deep and double, and are produced on long, stiff stems. The buds are long and pointed. Both in bud and flower it is truly beautiful. It lias a fragrance that is delicious-just like cherry blos soms. If you want a quick growing, hardy climbing. sure.to-bloom Rose, a quick growing, hardy. climbing. season, this is the only white variety that will do it. Price, 15 cents each; large size, to cents each.

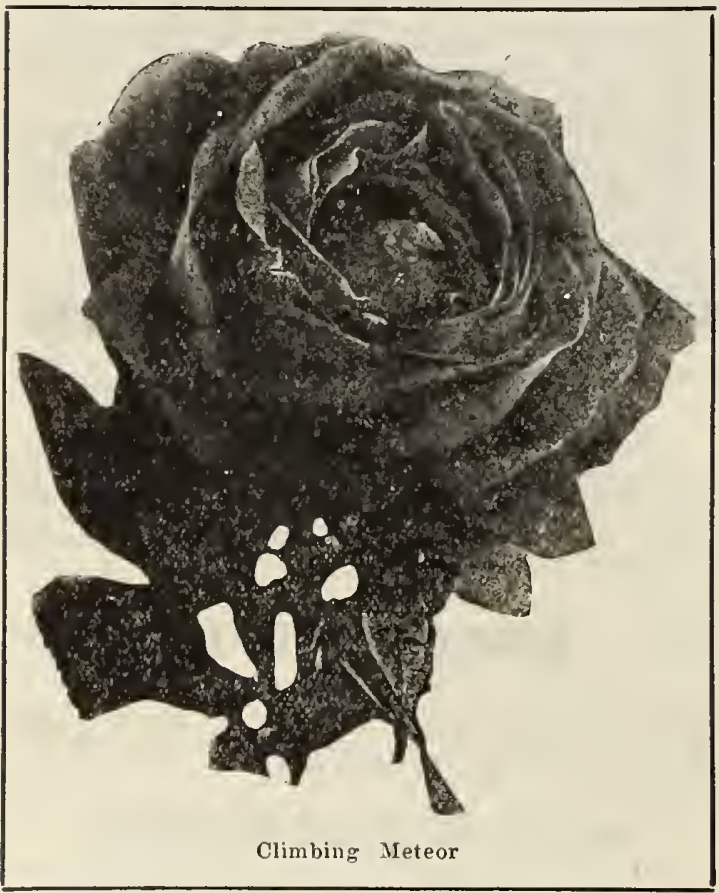

\section{CLIMBING METEOR}

superb crerblooming climbing Rose. A sport from leteor famous for its magnificent flowers. True climb. ing habit, attaining a heiglit of 10 to 15 feet in a single season. Free, persistent bloomer, with magnificently formed buds and flowers, Dark, velvety crimson, the equal of any Rose in cultivation. Hardy with protection, and will give absolute satisfaction, Price, 15 cents

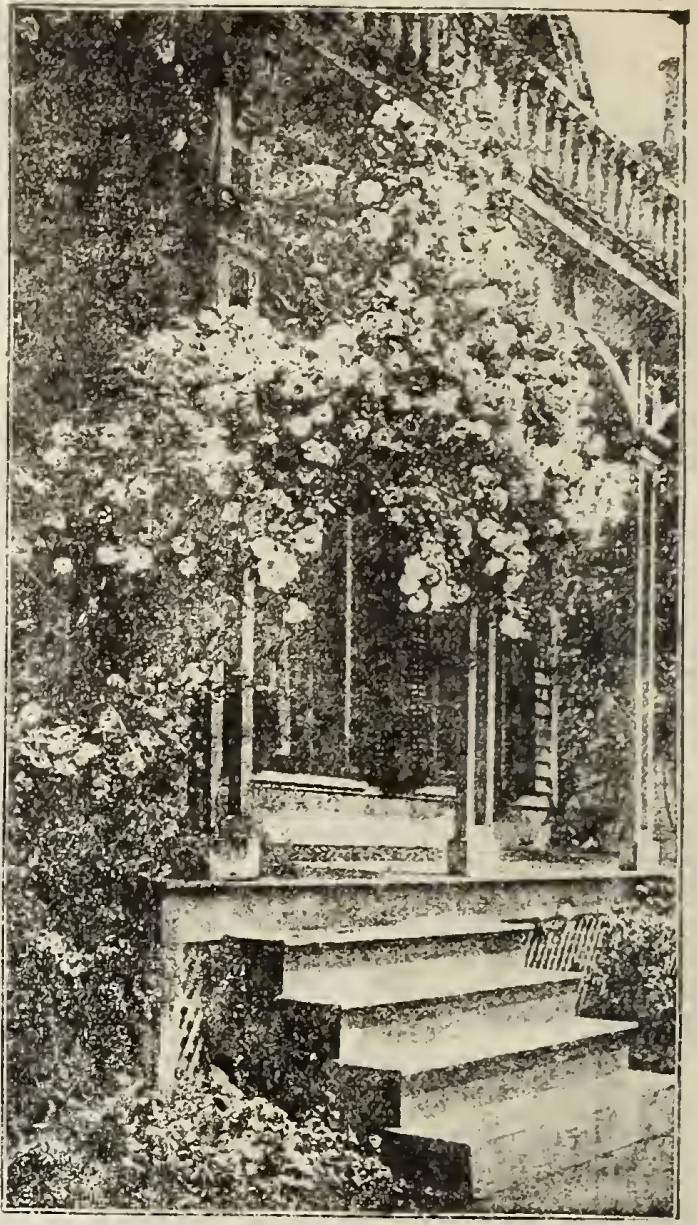

Climbing Clothilde Soupert

\section{CLIMBING OLOTHILDE SOUPERT}

Fnown the world over as one of the very best of all Roses. A stron dwarf grower and a truly wonderful bloomer, producing clusters after clusters of the finest formed flowers. Full and double, and dcliciously sweet. The color effect is beautiful-ivory-white shading toward the center to silvery rose. For training on feuces or porches it is one of the inost satisfactory Roses. Price, 10 cents each; two year old plants, 30 cents each.

\section{CLIMBING KILLARNEY}

Climbing Killarney is a sport of the now popular cut flower Rose Killarney and excels any rariety of its class and color ever intrnduced. Proved immensely popular last year. Climbing Killarney makes a strong growth, with a beautiful deen bronzy-green foliage, bearing its long. pointed buds and flowers on heary shoots and canes. The color is an exquisite shade of deep brilliant pink. Flowers immense in size, with petals of great substance and de lightful fragrance. A great new Rose. Price, 20 cents each; two year old plants, 45 cents each.

\section{CLIMBING DEVONIENSIS}

A sport from Devoniensis, from whicb it differs only in climbing babit of growth. It is fully as productive as the old sort, and being more vigorous, is justly a grand Rose. Color white, tinged with blush; very siveet. Price, 10 cents each; two year old plants, 40 cents each.

\section{PRESIDENT CLEVELAND}

\section{Climbing Marle Gulllot.}

It is one of the most rapid growing and vigorous climb. ing wbite Roses we have ever seen. It blooms continu. ously throughout the season. The flowers are magnif. cently made, extra large, deep and double. The bods are beautiful, and fragrance deligbtful. Price, 10 cents each; two year old plants, 30 cents each. 


\section{CLIMBING WOOTTON}

To our mind this ereat Rose is to be classed with Mr. Robert Penry and other great climbing varicties for thes resson. with wonderful vigor, blooms continuously tluroughout the growing season, producing flowers that are nothing less than superb, botll in beauty and in fragrance, If there is such a thing as having one rose inore beautiful than an ther, we think this variety may be entitled to this dis tinction. It is a strong, rampant climber, growing in one eason to a heirht of from ten to fifteen feet, with laroe leavy, insect-proof foliage. It produces in most wonderful profusion its superbly-formed flowers, wlich are bright magenta red, passing to violet crimson, richly shaded. The flowers are large, full and regular, with thick, leathery petals, and deliciously scented. Make beautiful buds. Price, 15 cents each; large size, 40 cents each.

\section{FRANCES E. WILLARD}

A strong and vigorous grower and true everbloomer Pure snow white buds, and flowers are of the largest size and perfect form. Exceedingly fragrant. Price, 10 cents each; two year old plants, 35 cents each.

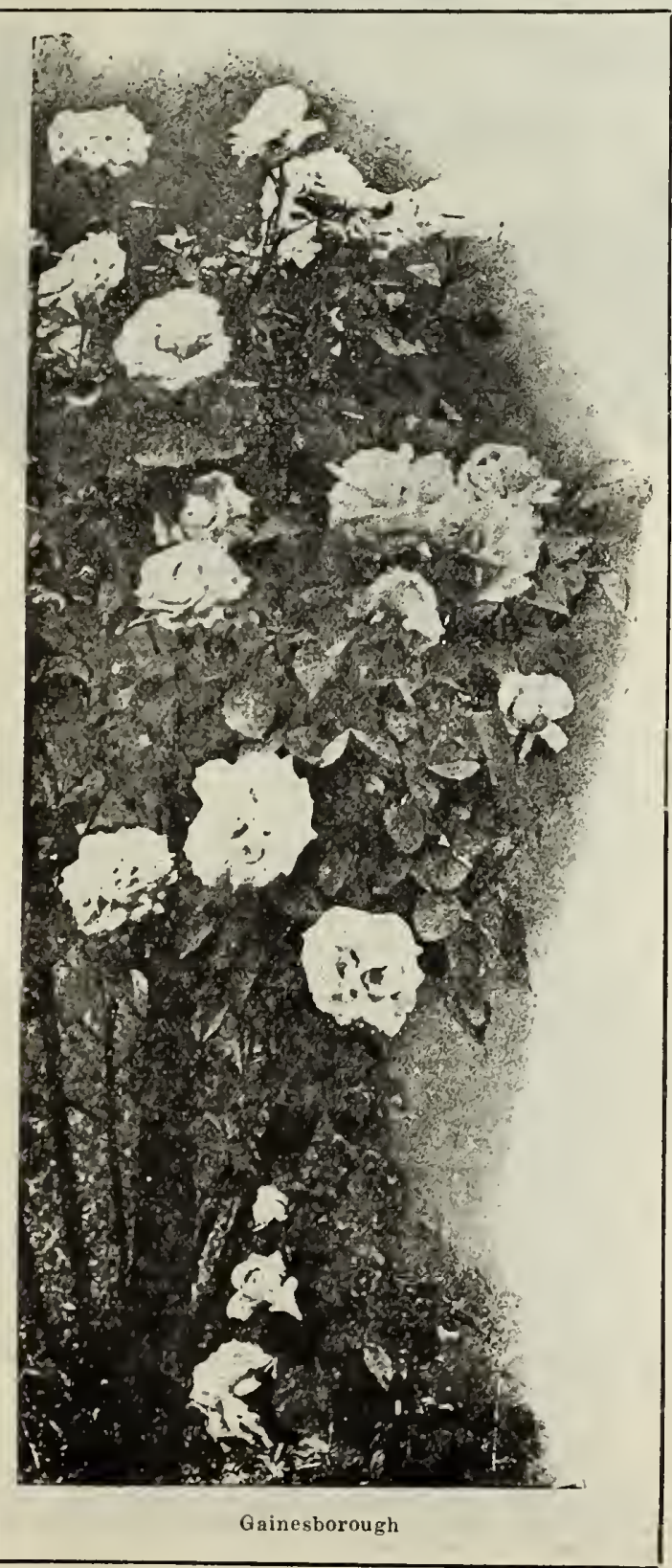

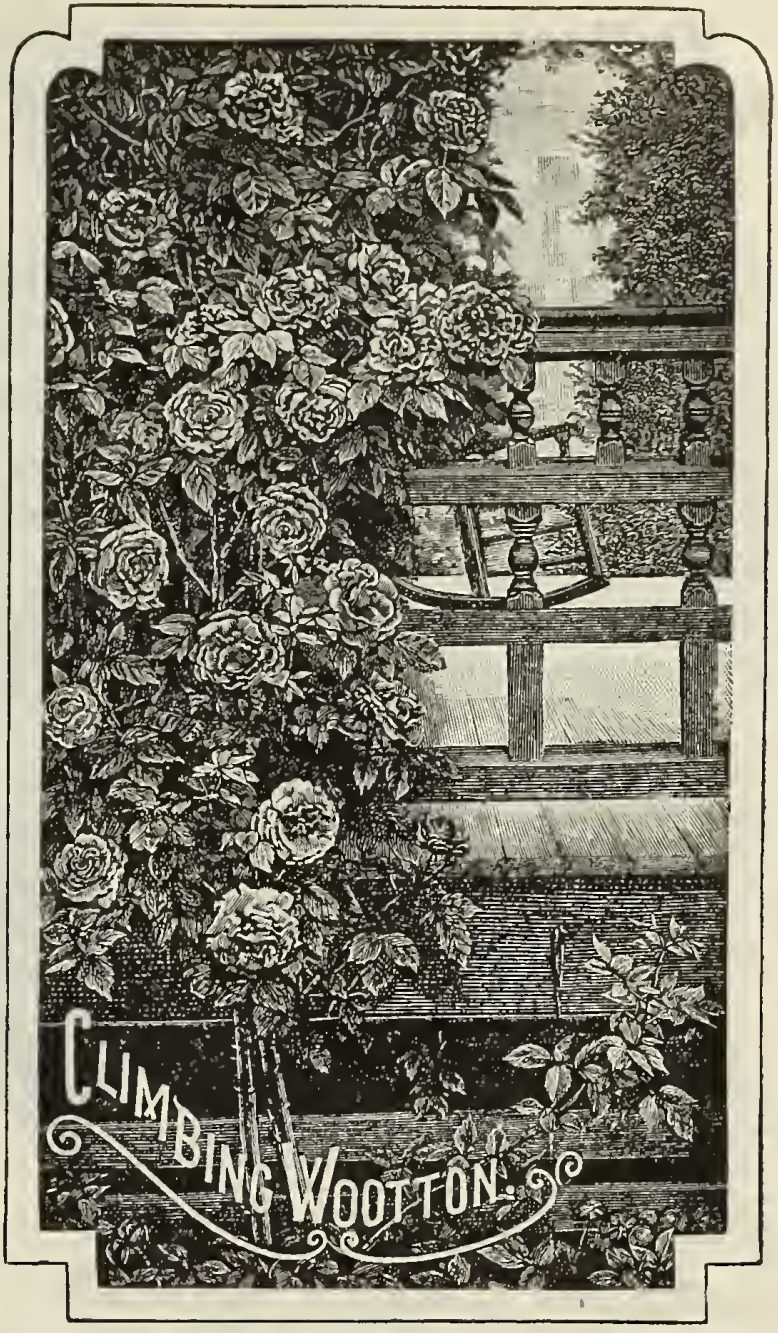

\section{REINE MARIE HENRIETTE}

A strong growing and climbing Rose, making a grand pillar Rose in the South. Flowers full and well formed: rich, brilliant crimson. A grand Rose and a fine com. panion to Marechal Niel. Try it. Price, 15 cents each; large size, 30 cents each.

\section{JAMES SPRUNT}

Deep cherry red flowers; medium size, full very double and sweet. Price, 10 cents each; large size plants, 25 cents each.

\section{CLIMBING MALMAISON}

This Rose is an exact counterpart of Malumison in foliage and flower, but is a rampant climber. You can not tell the flower or foliage from that old time, tried and true variety, Malmaison. It will be a welcome addition wherever climbing Roses are planted. Just imagine a Rose climbing over the side of your house or enclosing our veranda in its luxuriant foliage, bearing flesh colored roses of immense size, and double to center. Price, 15 cents each; large size plants, 30 cents each.

\section{GAINESBOROUGH}

This is a grand climbing Rose. We wish all of our customers could see its great beauty.

For a hardy everblooming climber it has no equal. For beauty and size we place this variety at the head of the Hybrid Teas. Its delicate colors are hard to describe, being delicately tinted flesh, almost white, and lustrous as satin. When in full bloom it resembles a large, fine, white, fluffy Peony, but without a suggestion of stiffness, often measuring eight to nine inches in diameter. Be sure and try this grand Rose. Price, 15 cents each two year old plants, 50 cents each. 
Yellow Marechal Niel

A beautiful, decp, sulphur rellow; very large and exceedingly fragrant. It is the finest yellow Rose in existence. It has a climbing habit, and where it is attains a large size, as it will in a few years, it vields thousands of beautiful, golden yellow fiowers. Especially desirable in the South. We liave a prand stoek of this rariety. Price, first size, 10 cents each; large and nicely shaped two year old bushes at 50 cents each; in extra strong robust fellow that will take care of himself anywhere-the best you ever got- $\$ 1.00$ each.

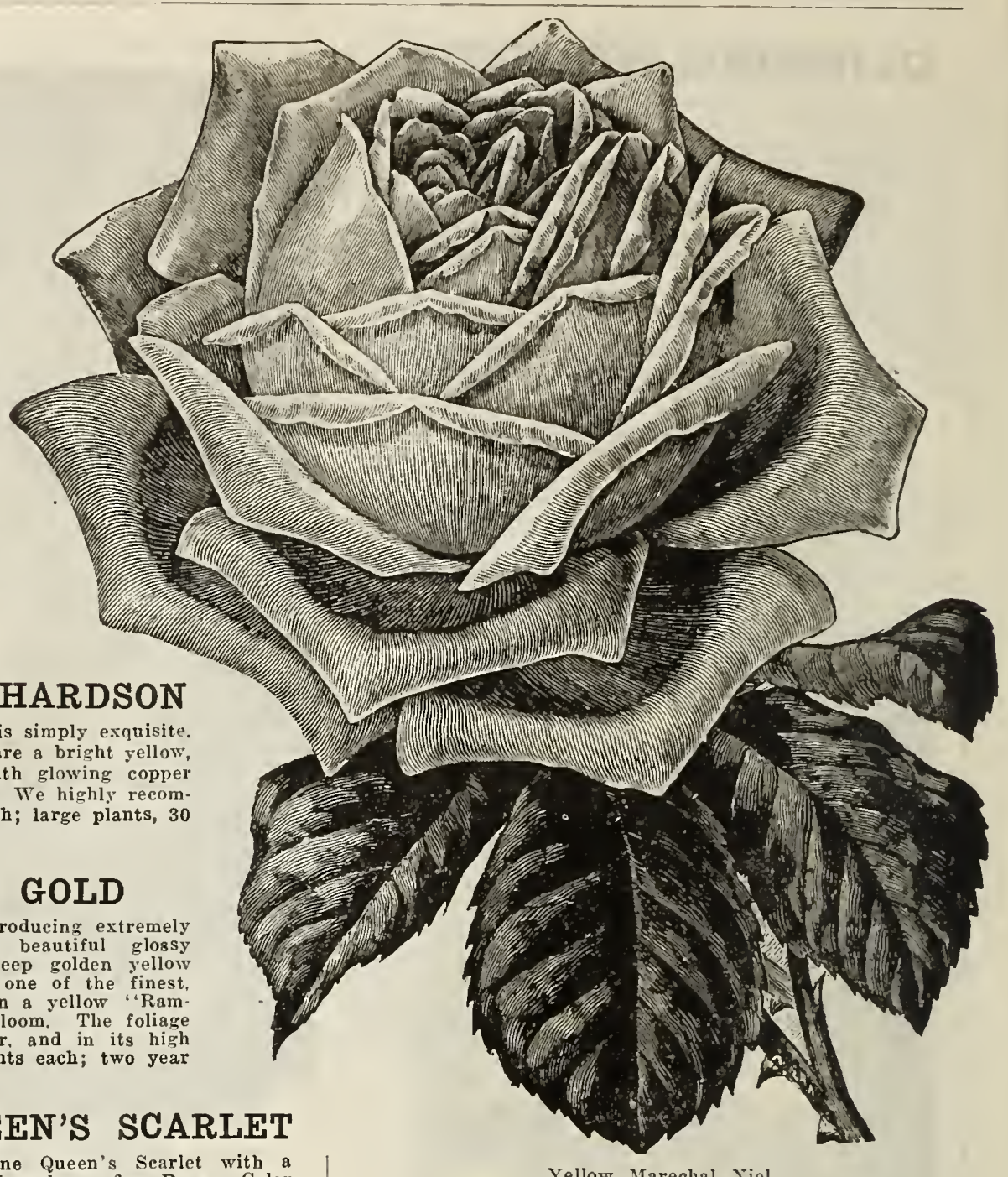

\section{W. ALLEN RICHARDSON}

The coloring of this Rose is simply exquisite. The base and back of petals are a bright yellow, the center highly colored with glowing coppe and rose; first class climber. We hiohly recommend it. Price, 10 cents each; large plants, 30 cents each.

\section{SHOWER OF GOLD}

A very vigorous grower, producing extremely long laterals covered with begutiful glossy Wichuriana foliage: color, deep and orange in fine trusses; one of the finest. learing little to be desired in a yellow "Ram bler." Produces a mass of bloom. The foliage is beautiful in form, in color, and in its high metallic luster. Price, 15 cents each; two Jear old plauts, 50 cents each.

\section{CLIMBING QUEEN'S SCARLET}

Climbing China. A genuine Queen's Scarlet with a vigorous climbing habit; will make a fine Rose. Color velsety crimson. Price, 15 cents each; two year old plants, 50 cents each.

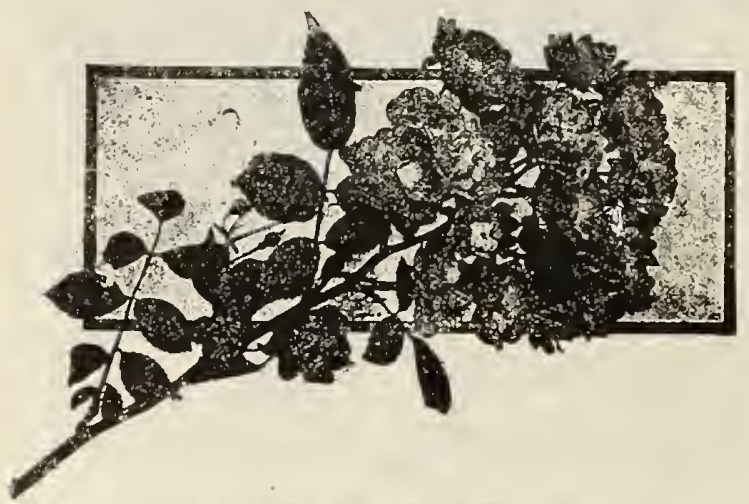

\section{EVERBLOOMING CLIMBING BABY RAMBLER}

MISS G. MESSMAN

This is a true everblooming Crimson Rambler, for at this writing (August 1st) it is in full bloom in thee gar. den with enormous heads of richest crimson. There has been a widespread demand for a Crimson Rambler that would bloom more than once. Here you have it. Every. one knows how Baby Rambler is always in bloom. This is simply a climbing form of the Baby Rambler emis simply a climbing form of the Baby Rambler, embe supplied this season. Price, 25 cents each.

\section{MARY WASHINGTON}

Flowers medium size, pure white, perfectly double to center, sweet and blooms all summer; fragrance tinged with old time musky flavor, so much admired in olden times. Price, 10 cents each; large size, 25 cents each.

\section{RUTH VESTAL \\ CLIMBING ROSE}

If you have never seen the Bride Rose arowing at its best in the open ground, you cannot conceive of the beauty of the large, bold, handsome flowers of this new white Rose. It has been termed the "Queen of White Roses," and while there are many white varieties of unquestionable excellence, there are none more reliable for outdoor cultivation than the Bride Rose. Climbing Rose Ruth Vestal is a sport from the Bride, and originated with us, and possesses all the valuable features of its famous parent from which it differs only in habit of growth. it is one of the most rapid growing and vigorous climbing Roses we have ever seen. It is an exceedingly healthy Rose, possessing every attribute that a perfect Rose should have. It blooms continously throughout the season, the first and every year. The flowers are magnificently made, extra large, deep and double. The color is pure snow white sometimes faintly tinged toward the edges with pale blush. Wherever Marechal Neil is grown this variety will undoubtedly equal it. Price, 15 cents each; two Jear old plants, 35 cents each.

\section{LAMARQUE}

A fine climber for greenhouses and conservatories; pale canary yellow, almost white; beautiful buds; large, full flowers, very double and sweet. Price, 15 cents each: large plants, 30 cents each. 


\section{WHITE DOROTHY}

In this grand new Rambler we at last have a hardy white climbing Rose which will grow in any part of the country under adverse conditions, and one which will rank up with Crimson Rambler and Dorothy Perkins as a pillar and porch Rose, As its name indicates, it is - sport from Dorothy Perkins, possessing all the fine qualities of that grand variety, but having pure snow white fowers. Price, one year old plants, 15 cents each; two year eld plants, 35 cents each.

\section{VEILCHENBLAN $\underset{\text { Rambler.) }}{\text { (Biue }}$}

This is the Blue Rambler which created such a furor in Europe. It is a seedling from Crimson Rambler with semi-double flowers produced in very large trusses. The flowers first open pink, but quickly change to a violet or steel blue. Totally distinct and a wonderful Rose for pillar and porch decoration. Price, one year old plants, 15 cents oach; two year old plants, 35 cents each

\section{DOROTHY PERKINS}

This beautiful new Rambler Rose is becoming even more popular than the original Crimson Rambler. And well it may, for it is indeed a finer pillar Rose than that famous variety. The growth of a single season is wonderful, its handsome, glossy green foliage being one of its strong points. The flowers, howerer sre its crowning beauty, being borne in immense clusters of fifteen to thirty, and possess great lasting qualities. Flowers a beautiful shell-pink, very double, with petals artistically crinkled. Remarkably pretty pointed buds. This Rose is extremely hardy and will withstand the coldest weather. We advise our friends to plant this variety where it can be allowed plenty of room, and it will give an account of itself. Price, one year old plants, 10 cents each; two year old plants, 25 cents each.

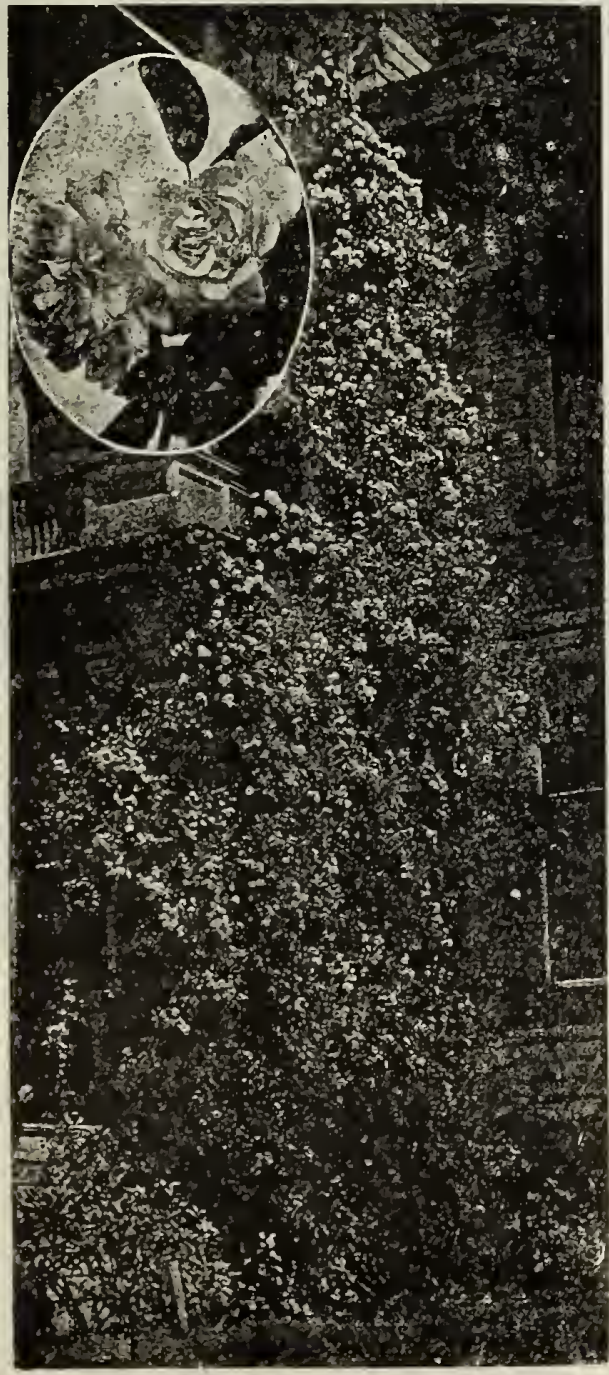

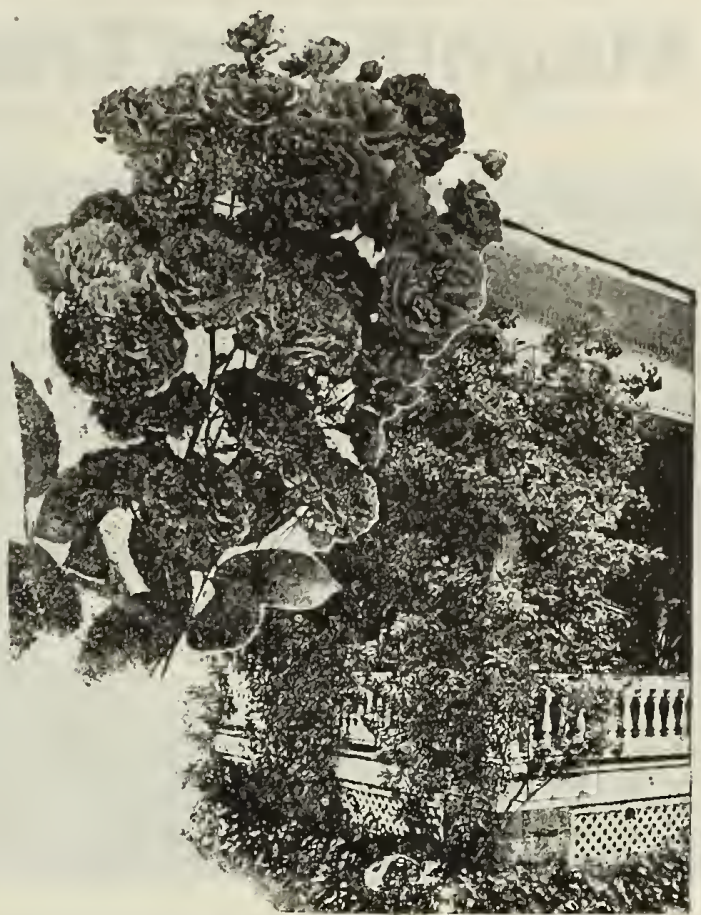

Excelsa

\section{RAMBLER ROSE}

A splendid new Climbing Rose, remarkable in many ways, but particularly in the brilliant fiery-red, or intense crimson-scarlet of the flowers. The intensely brilliant color is accentuated by the great masses of giant trusses produced on the plants, and furthermore by the contrast with the deep green, glossy foliage. The flowers are very double; they are larger thsn any of the Rambler Roses and borne in trusses of thirty to forty on each; the body of the flower is brilliant in color, but toward the edges of the petals they light up with a wonderful scarlet-crimson. Price, one year old plants, 20 cents each; two year old plants, 50 cents each.

\section{AMERICAN PILLAR}

The flowers are single, of immense size, three and four inches across and very durable. They hang in immense clusters all along the branches and make a remarkable sight, a veritable sheet of bloom. The color is a dainty apple-blossom pink, while in the center of each flower is a cluster of bright yellow stamens. This Rose is as hardy as an oak tree, of very strong growth, soon corering any space allotted to it. The American Pillar is going to become as popular as the Crimson Rambler. If you want a novel and beautiful garden ornament, order this Rose Price, one year old plants, 20 censt each; two year old plants, 50 cents each.

\section{DR.W. VAN FLEET}

Dr. W. Van Fleet bears flowers which, when open run four inches and over in diameter. The center is built high, petals beautifully undulated and cupped. The color is a remarkably delicate shade of flesh pink on the outer surface, deepening to rosy flesh in the center. The flowers are full and double, of delicate perfume, buds pointed, stems twelve to eighteen inches, and fine for cutting. The foliage is a peculiar shade of bronze green, large and glossy, with spines a hright bronze red. The variety is a vigorous grower, immune from mildew. plants, 50 cents each.

\section{TAUSENDSCHON \\ (Thousand Beauties.)}

Imagine a Rose producing on the same bush so many different colored flowers that it is impossible to describe or eren picture the variations. The colors run from delicate balsam or tender rose through the intermediate shades of bright rose and carmine, with white, yellow and various other delicate tints showing. It is a strong grower, impervious against mildew and absolutely hardy. For climbing over porches, single specimens or pyramids, to 10 cents each; two year old plants, 30 


\section{Magnificent Trial Offer}

This is a Standing Offer of Ours to Send Twenty Cholce Roses, Each One Labeled, for the Small Sum of One Dollar

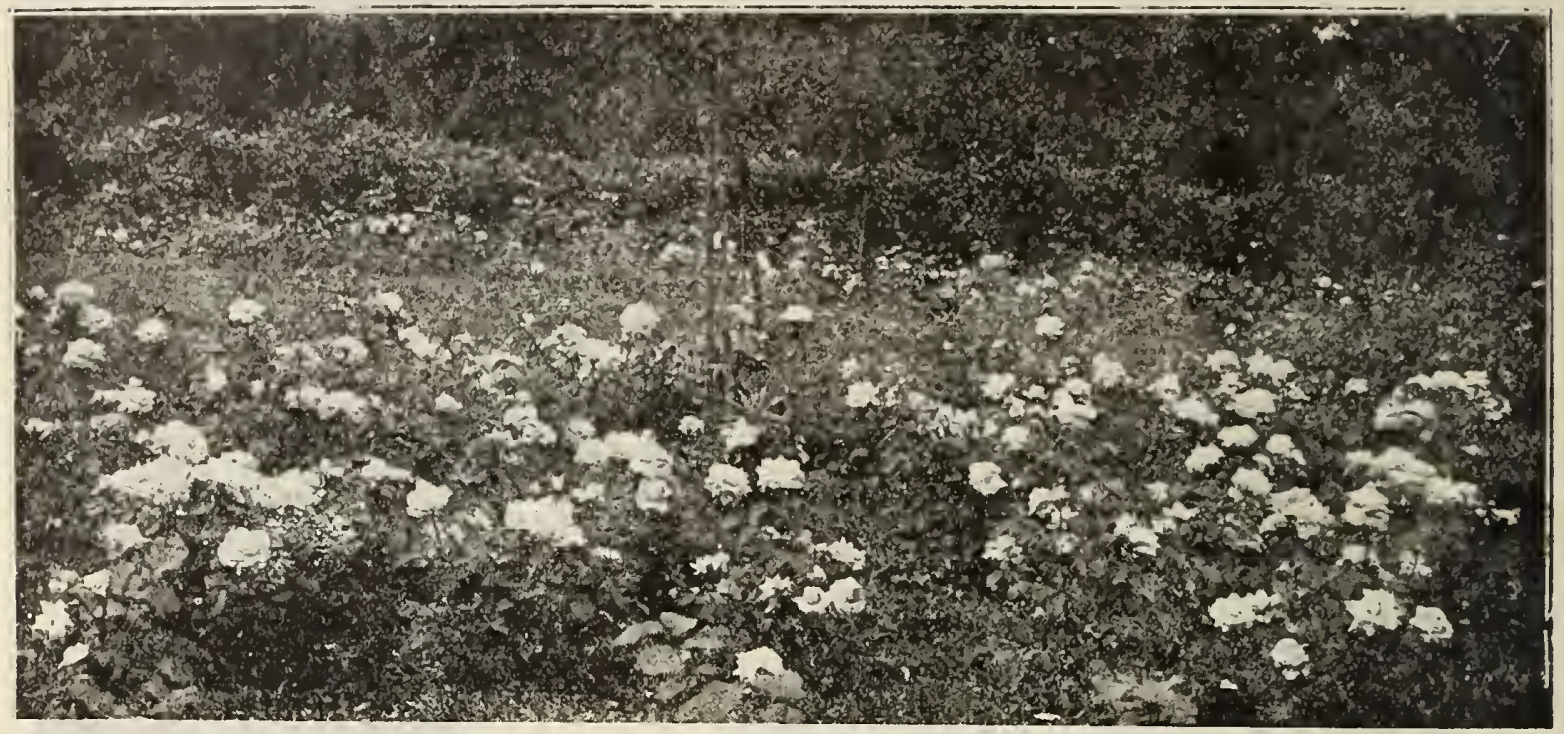

Our "Trial Order" Collection of Roses, Three Months from Planting. Beds of Vestal's Roses Are a Constant Source of Pleasure and Delight.

The love of Roses is universal, and fortunate it is that the most beautiful ones live out of doors and thrive in ordinary gardens. Be liberal with the fertilizer in preparing your rose gardens; they will return many fold in the way of luxuriance and profusion of blooms.

This offer is only made to induce you to give us a trial, and it will be to our interest to send only a fine assort ment of good Roses, well rooted, that are sure to bloom freely the first year.

THERE WILL BE NO DISCOUNT ALLOWED ON THIS OFFER

but if you induce four of your friends to club with you, enclosing $\$ 5.00$, we will send either by mail or express fire uf our sample collections of twenty Roses, and for your trouble will allow you to select any five of our elegant twenty-five cent Roses. The name and address of each of these five persons must accompany the order.

REMEMBER, we send twenty choice everblooming Roses of our selection for $\$ 1.00$, but you must not include it in your order when discounts are taken. We send six collections of our twenty sample Roses for $\$ 5.00$.

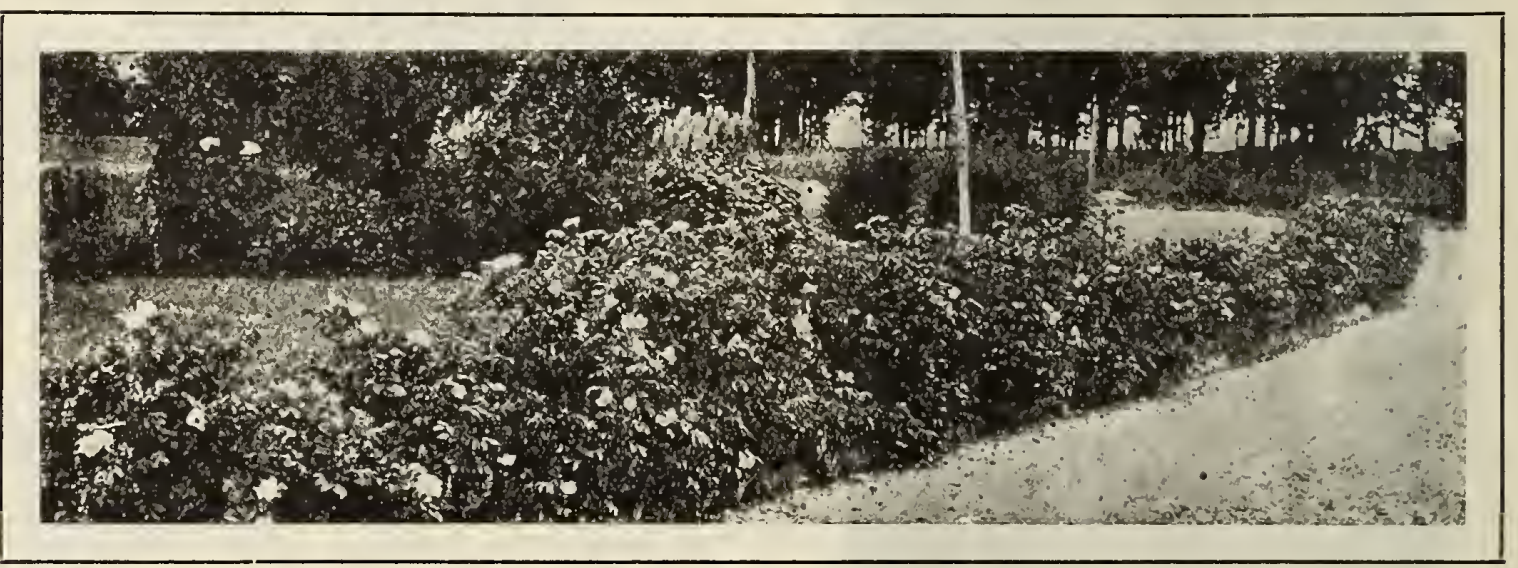

\section{ROSE HEDGES}

Almost every one who can find any place at all to put it wants a hedge of Roses. There is something both tropical and romantic about the idea of Hedge Roses that strongly attracts every one. We can supply any of the fine Jush Roses in quantity for hedges, and any of the beautiful Trailing and Climbing Roses for covering walls and fences.

NOTE-We pay all postage on Roses and Plants sent by mall, but when sent by Express the purchaser pays the Ex. press charges. Two year Roses should always go by Express, unless to very distant points, as we can send larser and better plants in this way, and when packed with the tops on and some earth on the roots they arrive in the best condition to grow and bloom quickly.

OUP FALL CATALOGUE On the first of September we issue a Catalogue of Bulbs and Plants for Fall Planting and Winwho we Blooming. We mail this Catalogue to all our customers, and will send it free to others 

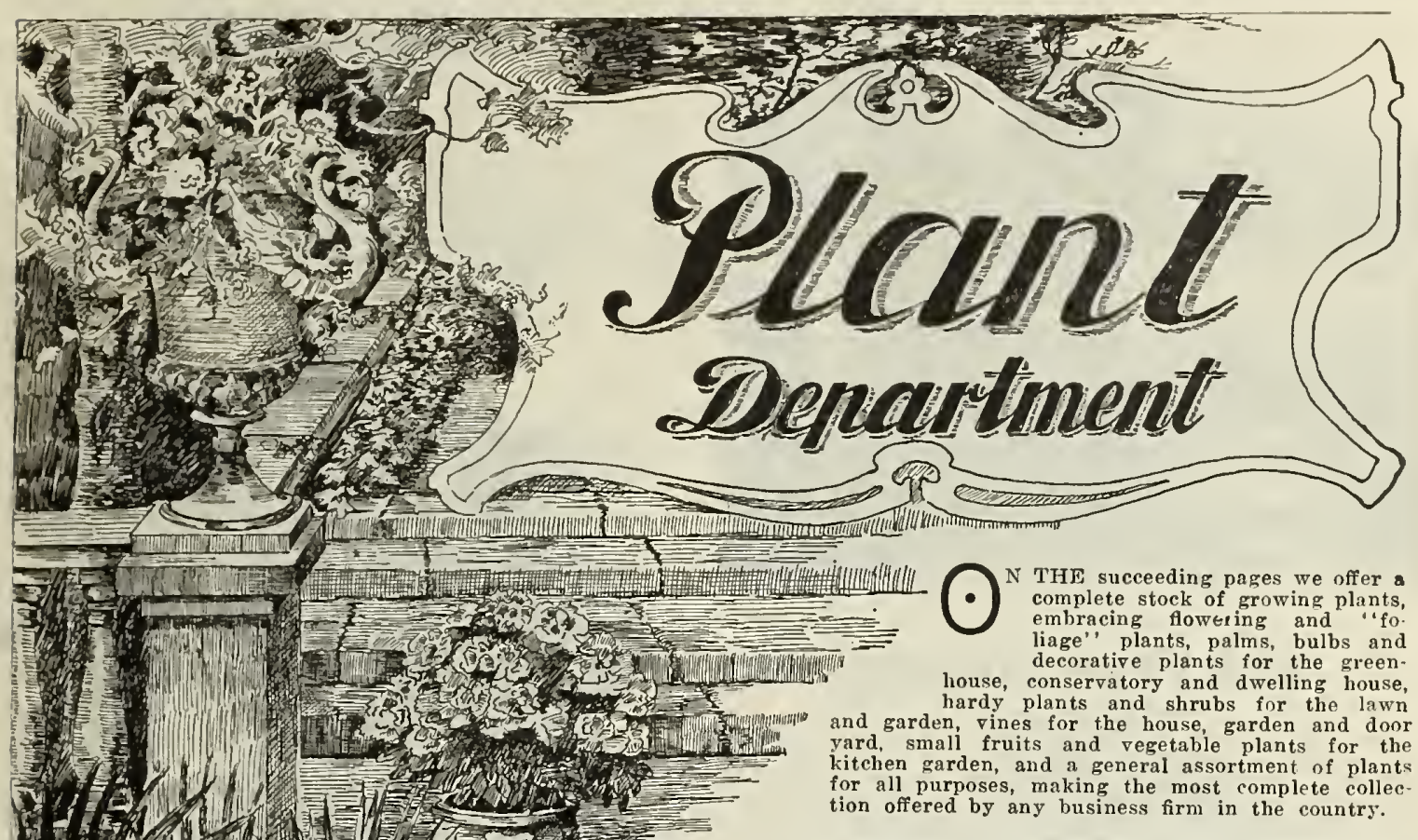

\section{GOLDEN SPOTTED ABUTILON}

ECLIPSE. This is a novel and distinctive variety. The leaves are beautifully spotted with golden yellow on a green ground. The flowers are orange yellow, and are produced abundantly. An excellent plant for edging foliage beds. As a basket or vase plant it is unsurpassed. As a specimen in the window or conservatory it has few equals. Price, 10 cents each.

\section{ABUTILONS}

CHINESE BELLFLOWER OR FLOWERING MAPLE

Rapid growing plants of easy culture. Flowers pen. dulous, bell shaped and produced in great abundance pentaken up carefully before frost, they make good winter flowering plants. Price, 10 cents each; three varieties for 25 cents.

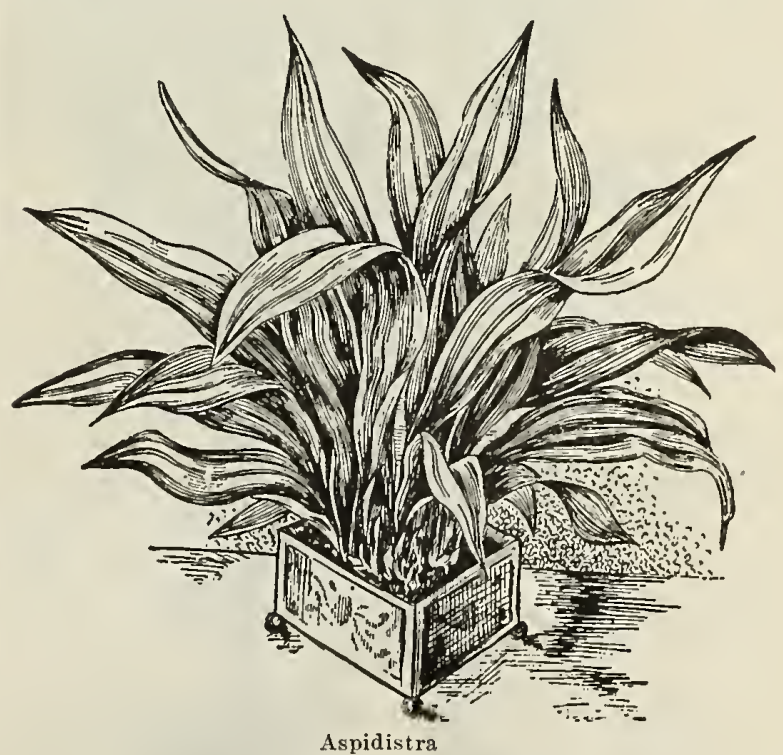

\section{ASPIDISTRA}

Ranks with Coleus as a bedder, but more hardy. Retains its brilliant coloring all the season. Price, 5 cents ch; 25 for $\$ 1.00$.

BRILLTANTISSIMA. Leaves and stems of a beautiful ruby red. Splendid for bedding.

McNALLY. Golden yellow, reined green.

One of the most useful house plants. On account of its ability to thrive indoors it has been frequently alluded to as "The Cast Iron Plant." It has long, broadly lanceolate leaves gracefully disposed. Price, 25 cents each. 


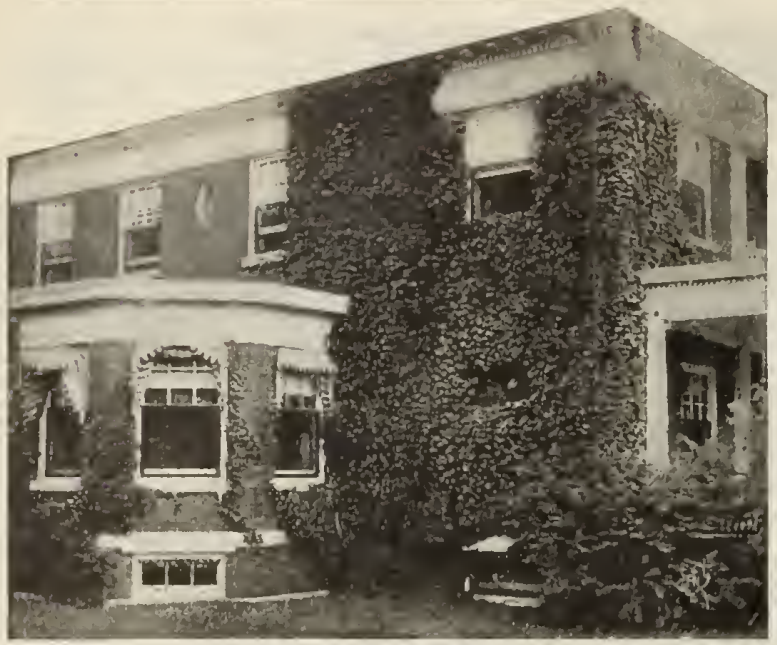

Ampelopsis Veitchii

\section{ACALYPHA SANDERI CHENILLE PLANT}

One of the most gorgeous fiowering plants thus far discovered. It grows up a straight, stout branching plant, clothed with large green leaves of good substance, and out of the axil of every leaf grows a spike of blossom, glowing crimson-scarlet in color, twenty to thirty inches long, as large around as one's finger, and looks like a long piece of crimson-scarlet chenille cord. They last for months before fading, and before they fall off several spikes have started out in the same leaf axil, and it is thus always in bloom. Price, strong healthy plants, 10 cents each; three for 25 cents.

\section{ACALYPHA BICOLOR COMPACTA}

The leaves are a bright green, margined with a wide, irregular band of lemon yellow, and having wide yellow bars running lengthwise of the leaf, and also thickly dotted with yellow blotches. This is a first class plant for greenhouse decoration: it will stand bedding out like a Coleus; in fact in the sunniest places, it produces the highest coloring. Price, strong healthy plants, 15 cents each; two for 25 cents.

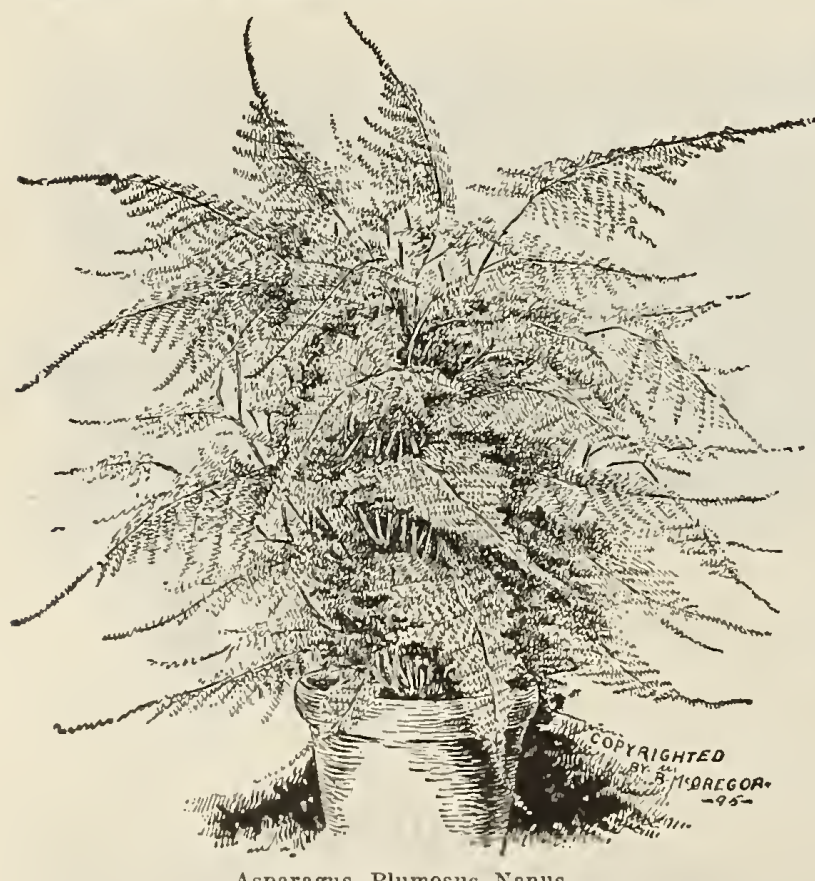

\section{Ampelopsis Veitchii}

BOSTON IVY

A beautiful, hardy climbing plant, of Japanese origin. This is one of the finest climbers we know of for covering walls, as it clings firmly to the smoothest surface, covering it smoothly with overlapping leaves, which form a perfect masa of foligge. The color is a fresh, deep green in summer changing to the brightest shade of crimson and yellow in autunn. It is quite hardy, and becomes more popular every year. Price, stiong plants, 15 cents each; four for 50 cents.

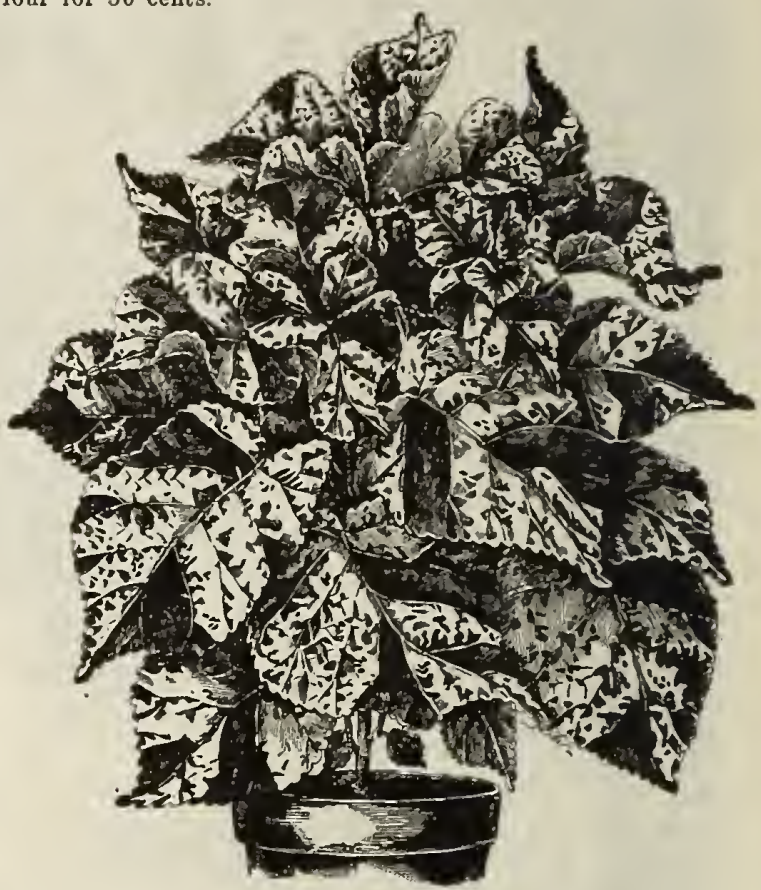

Acalypha Triumphans

\section{Acalypha Triumphans}

This is one of the most beautiful foliage plants we hare ever seen. It is a strong, healthy grower and makes : compact plant of splendid dimensions. The foliage is large (about $2 \times 4$ inches), very heavy and showy beyond description. The predominant color is red, marbled lighter and darker, streaked and dashed green, yellow, white and other colors, giving a most striking effect to be had with no other plant. Price, fine plants, 15 cents each.

\section{Asparagus Plumosus Nanus}

One of the handsomest of our foliage plants. The leaves are a bright green, gracefully arched, and as finely woven as the finest silken mesh. Their lasting quality when cut is remarkable, retaining their freshness for weeks, hence it ranks as the most valuable plant we have for this purpose, surpassing the Maiden Hair Fern in grace, fineness of texture and richness of color. See illustration. Price, 10 cents each; large plants, 20 cents each.

\section{ASPARAGUS TENUISSIMUS}

A beautiful species of climbing habit, remarkable for the delicate appearance of its foliage. As a decorative plant it is very striking, and for contrast with foliage of other plants it is one of the most effective. The sprays are beautifully used with cut flowers in the arrangement of boquets or vases, and last a long time after being cut. Price, 15 cents each; large plants, 25 cents each.

\section{SPRENGERII \\ NEW ASPARAGUS}

A desirable species, useful as a pot plant or for baskets fronds frequently 4 feet long; a rich shade of green, re taining freshness for weeks after cutting; fine house plant, as it withstands the dry atmosphere. Price, 10 cents each; large plants, 20 cents each. 


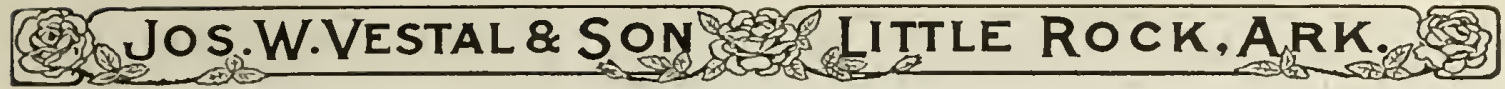

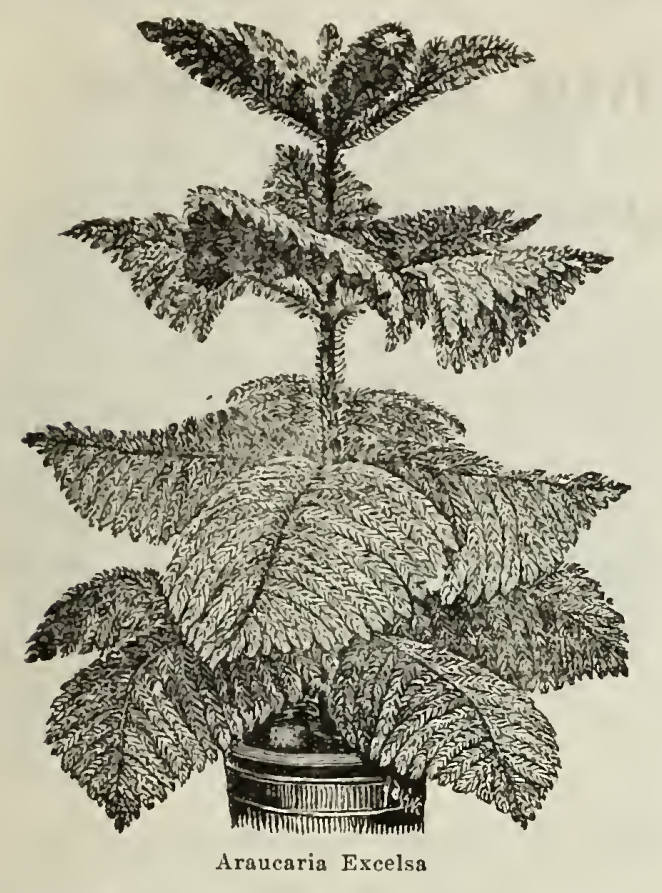

\section{ARAUCARIA EXCELSA}

NORFOLK ISLAND PINE

This beautiful plant is well adapted to house culture and is almost indispensable as a decorative plant. The dark green branches are arranged in symmetrical whorls, producing a very unique and graceful appearance. Must be sent by express; too large to mail. Price, 12 to 15 inches, $\$ 1.00$ each.

\section{ALTERNANTHERAS OR DWARF COLEUS}

Price, 5 cents each; 50 cents per dozen; $\$ 3.00$ per 100 . AUREA NANA. It is admirably adapted for ribbon lines, carpet bedding, or massing front lines in foliage beds. It is of compact growth. Color of foliage, bright golden yellow.

BRILLIANTISSIMA. Crimson, scarlet and pink. Its gorgeous color gives it the name of "Rainbow Plant."

PARYONCHOIDES MAJOR. It is the Alternanthera so largely used in all ornamental carpet gardening. It grows only about six inches high, and can be kept much shorter by shearing it. The color is as bright when first planted as at any other time, and this is kept constantly. The color is brightest carmine.

\section{TWO NEW ALTERNANTHERAS}

CROTONII. Golden yellow, with lacings of vivid green; everybody admires the golden bands of the Aurea Nana, and Crotonii is this same variety reproduced in giant size, and with the colors intensified; will be found valuable in bedding, as it produres a finished effect in a very short time after planting. Price, 10 cents each; per dozen, $\$ 1.00$.

JEWEL. Surpasses Parychoides in brilliance. freedom and size of growth: color, rasy carmine and bright cerise. Price, 10 cents each; per dozen, $\$ 1.00$.

\section{ARDISIA CRENULATA}

A very ornamental greenhouse plant, with dark ever green foliage, producing clusters of hrilliant red berries; a first-lass house plant in winter. Price, 50 cents each

\section{UMBRELLA PLANT \\ CYPERUS ALTERNIFOLIUS}

A splendid plant, throwing up stems two or three feet high, surmounted at the top with a whorl of leaves, diverg. ing horizontally, giving it a novel appearance. Fine for center of vases, decorative purposes or aquariums. Price, 15 and 25 cents each.

\section{ARONDO DONAX VARIEGATA}

May be uscd either as single specimens or in groups, its broad foliage, crcamy white and green stripe contrasting well witl other foliage plants. It is perfectly lurdy, lut nceds protection from damp in winter. It rrows tun fuet high, is of graceful form and fine habit. It may be increased by division in the spring. Price, 25 cents each,

\section{AGERATUMS}

MAYFLOWER. Dwarf, compact growth, learing at profusion of pure white llowers. Price, 5 cents eicn.

STELLA GURNEY. New Ageratum. A short, compact grower, well branched and extrcmcly free bloowing; the individual tufts are very large and dense; color is iutense blue. Price, 5 cents each.

LITTLE BLUE STAR. A new true dwarf Ageratum never attaining over from six to eight inches in height. An extremely frce bloomer. The individual tufts are $\nabla$ er: large and dense, and the color it an intense blue. Price, 5 cents each.

PRINCESS PAULINE. A novel and distinct variety of dwarf, compact habit, rarely excecding six inches in height, its peculiarity being that both colors, blue and white, are combined in same flower. Price, 5 cents each.

BIUE PERFECTION. Bright blue flowers: very free blooming habit winter and summer; twelve to fifteen inches high. Price, 5 cents each.

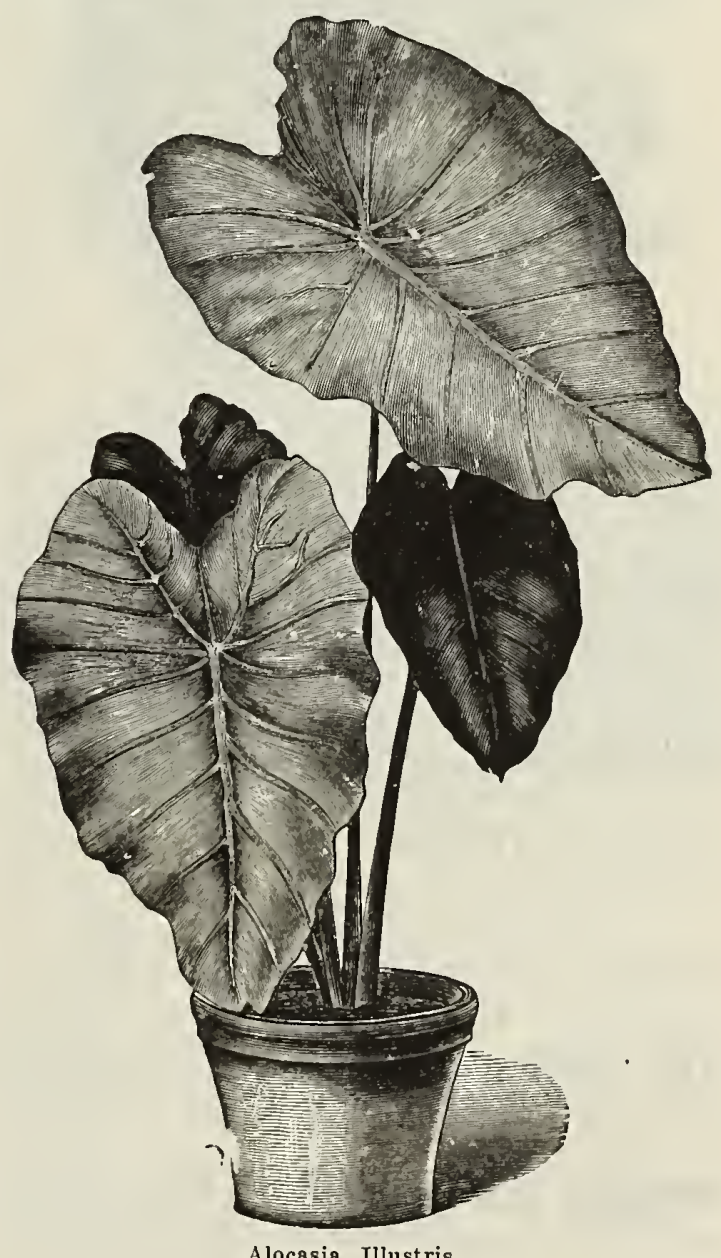

\section{ALOCASIA ILLUSTRIS}

An excellent plant to grow in connection with fanc. leaved Caladiums or for planting in the open border in partly shaded position. The foliage is large, of a dark green, clouded with a velvety blue black. Planted in light, well enriched soil, with a good supply of water, it makes plants two feet high, which form a striking object in sub-tropical gardening. Price, 25 cents each; five for $\$ 1.00$. 


\section{Choicest Flowering Begonias}

PRICE OF ALL BEGONIAS, EXCEPT WHERE NOTED, 10 CENTS EACH

ALBA PICTA ROSEA This is a acedling of Alba Foliage rich green, spotted witl white; flowers on long. pendant stem, similar to Rubra. Color, delicate rose: very free flowering.

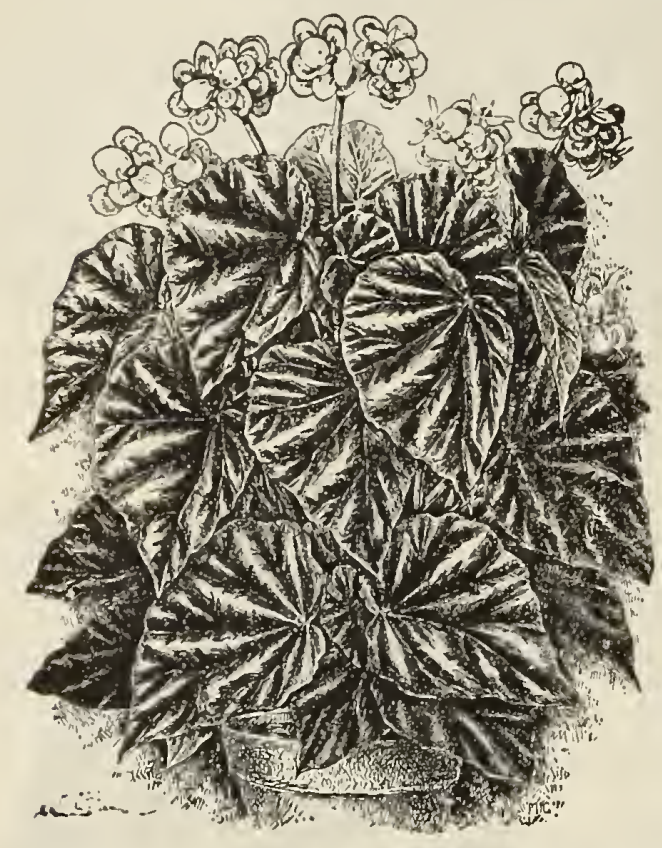

ARGENTEA GUTTATA New Begonia. It has purp?t silvery markings and is in every way a most beautiful Begonia. It produces wlite flowers in bunches on ends of growth stems. It is splendid for house culture.

BEEFSTEAK BEGONIA FEASTII A low, spreadin : fectly circular leaves, red beneath, and dark glossy green above, and of heavy texture. The finest pot Begonia we have for house culture. Don't fail to try it. Price, 15 cents each.

ALBA PICTA Very ornamental; has long, ear shaped, green, with silvery spots.

CORALLINA IUCERNA A superb new variety of the gantic trusses of bronzy red forwers and flowering contin. uously from April to November. The foliage is ditted with silvery white. Price, 25 cents each.

CUPRA A seedling from Metallica, with beautiful velgrower. Bound to become popular.

PINK RUBRA We doubt if there is a pink flowered variety that equals it. The foliage re. sembles Rubra in shape, hut is a lighter green, while the fower's panicles are much handsomer. It is a pure pink flowering Begonia.

MARJORIE DAW Semi-climbing or trailing habit. panicles. A rapid grower; bright green leaves; an excellent rariet

MARGUERITE Leaves a bronzy green, somewhat re bushy form. Light rose colored flowers.

SANDERSONII Coral Begonia. One of the best flower shade of crimson, ing Begonias. The flowers are a scarlet
GRACULS LUMINOSA As the name implies, it is and yet graceful plants we have every known; very str ng and robuat, but still keeping its shape so as to make a very attractive winter liouse plant. The flowers, when first opening, are bright cherry, changing to a clear coral red.

THURSTONII A distinct and pretty shrubbery variety, rich metallic grcen onick heavy loliage, which is of flowers are a fine pink, rising well above the foliage. M. DE LESSEPS New Begonia. It is beautifully TOMENTOSA This Begonia has white tipped, rose RUBRA If you can have only one Begonia, let it be a Rubra, for it will prove a constant delight. It top of your wing that it will, in a year or two, reach inc in diameter, and rising beside then will grow strong slender branches, gracefully drooping under heavy waxen leaves and pendant panicles of coral colored flowers as large as a hand.

PRESIDENT CARNOT New Begonia. A remarkably very large; flowers coral red, in large pendant paniclec, similar to Rubra. but much larger. Price, 15 cents each.

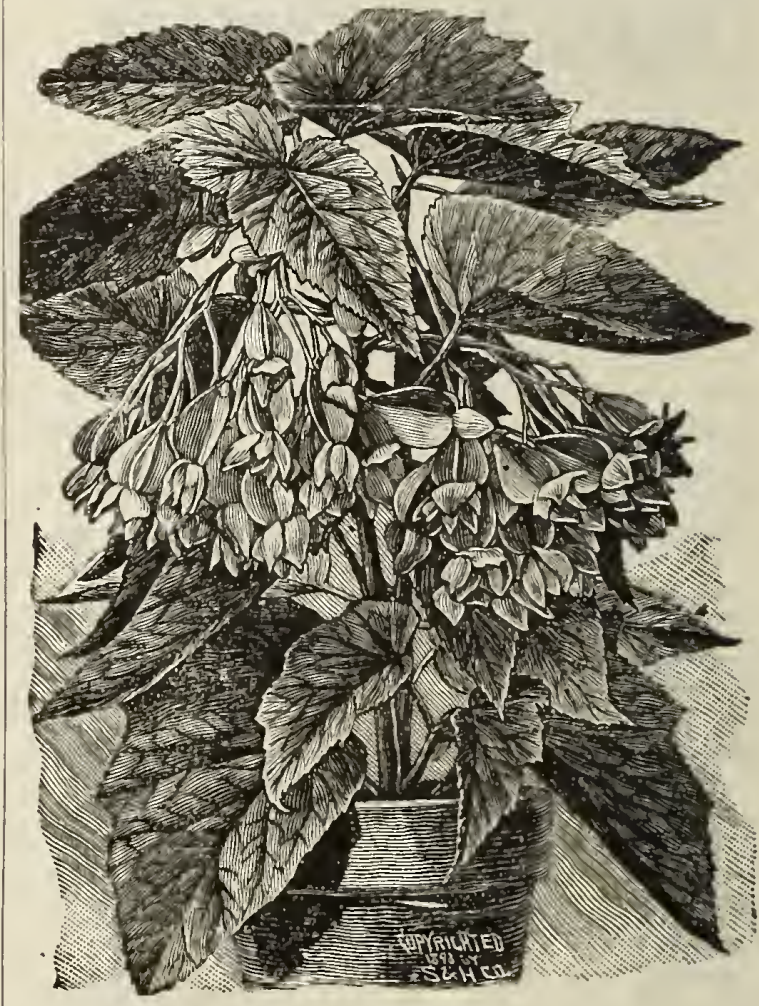

7ERPINA An erect growing variets, with a beautiful LERINA profusion of pendant leaves. The leaf is distinguished by its glistening silver shading following the leaf, the body being rery dark velvety green: uuder aide plum color, veined green. Flowers pure white

WELTONENSIS A rery handsome winter flowering pink flowers.

NTIDA ROSEA Glossy leares of medium size, bloom NTIUA ROSEA extremely beautiful; large panicles of soft rose color. 


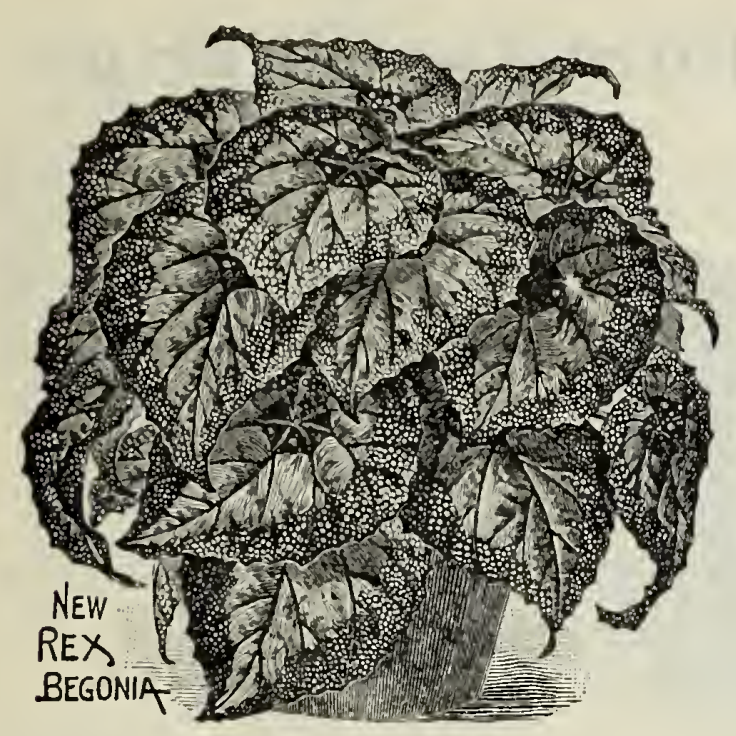

CHRISTMAS PEPPER OR JAPANESE PEPPER

$A$ very raluable quick growing red berried plant. Oom. pletely covered with coral red berries, one.half to threefourths incli in diametcr the entire winter months. One of the best winter decorative plants. Price, 10 cents each.

\section{Chinese Cinnamon Vine}

PRIDE OF THE FLOWERY KINGDOM

Beautiful leaves, dainty flowers, exquisite perfume. Most desirable, easily grown, rapid climber in the world. This Oriental Gem of the Far East comes to us a marvel of beauty and fragrance. Its rapid growth, abundant foliage and modest, sweet scented flowers, give it supremacy over all foreign and domestic climbers. The handsome glossy, heart-shaped leaves and clusters of fragrant white flowers make a window arbor or veranda a perfect bower of beauty. They stand the severest winter, and burst forth in all their beauty and splendor very early in the spring. No one should miss planting this charming vine. Once planted, will grow a lifetime. Price, of Cinnamon Vine tubers, or roots, extra quality, sure to grow, 10 cents each; three for 25 cents.

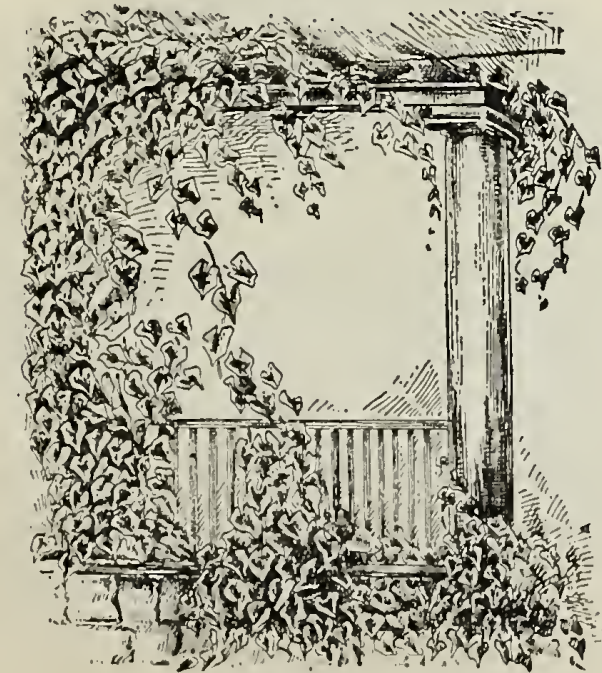

Chinese Cinnamon Vine

\section{Begonia Rex}

They ure the liandsomest of all Begonias, and the most admired by all. Try a set of them. We have five leading and distinct kinds that we can furnish. Price, 20 cents each; three for 50 cents; eight for $\$ 1.00$.

\section{BEGONIAS TUBEROUS}

Our strain of these is grand. All new types, finest colors, lnrgest nnd most perfect blossoms. Double Tuberous Begonins are perfectly exquisite. The colors are bright carmine, rose color, scarlet, bright orange, etc.

DOUBLE FLOWERING. Extra fine. Price, 15 cents each; $\$ 1.50$ per dozen.

SINGLE FLOWERING. Strong bulbs. Price, 10 cents each; $\$ 1.00$ per dozen.

\section{BANANA ORINOCO}

One of the finest Bananas for pot culture, and fruits splendidly. The leaves are borne in a palm like crown or cluster, each leaf three to five feet long and two feet broad; of a clear shining green, curved and crinkled in the most pleasing manner. The most beautiful foliage plant that can be grown outside of a hothouse. Grand for bedding out in the summer, or for conservatory or warm window decoration. Can be kept unwatered in a warm rellar over winter. Price, 25 cents each; five for $\$ 1.00$. Large, by express, 50 cents each. Extra large, $\$ 1.00$.

\section{CAMELIA JAPONICA}

Leaves glossy green and flowers of the most exquisite beauty. From pure white to crimson in almost endless variegation. Requires shade and moisture throughout the hot season. Their time of blooming is winter and early spring. When set with flower buds great care must be taken in watering - when left too dry the buds are sure to drop. Price, large plants, by express, $\$ 1.00$.

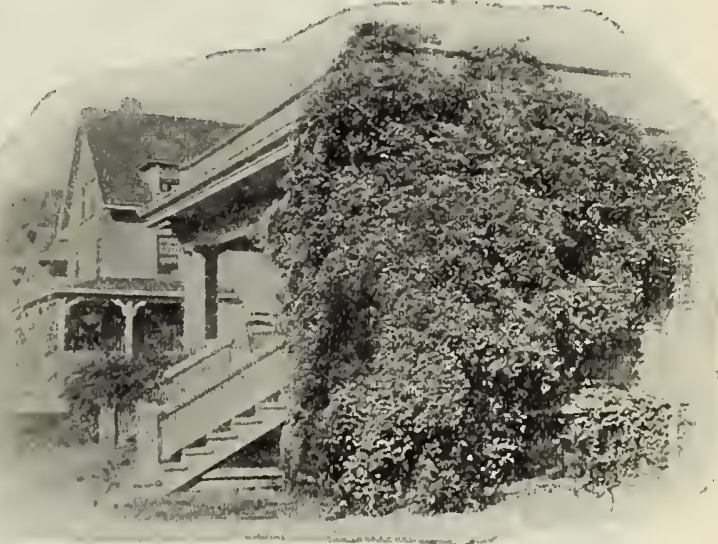

Clematis Paniculata

\section{Clematis Paniculata}

NEW SWEET SCENTED JAPAN CLEMATIS

Flowers are rich creamy white, star shaped, and borne in beautiful clusters, completely covering the vine with beautiful star shaped blossoms, exceedingly fragrant; the sweetest of all Clematis, and one of the hardiest and easiest to grow. Price, good strong plants, 15 cents each; two for 25 cents; $\$ 1.50$ per dozen.

\section{RED, WHITE AND BLUE CLEMATIS}

THE GRANDEST VINES THAT GROW

JACKMANII. Its rapidity of growth, matchless freedom in blooming, and the superb velvety purple of its large flowers have always been held in that relation to other Clematis which Jacqueminot holds to hardy Roses. The blooms are royal. Price, 50 cents each.

HENRYII. Large, pure white, the best of all white Clematis. Price, 50 cents each.

MAD. ED. ANDRE. This is the nearest approach to a bright red Clematis, and has been called the Crimson Jackmanii. Tlie plant is a strong, vigorous grower, and very free in bloom. Color, distinct crimson red. Price, 50 cents each. 


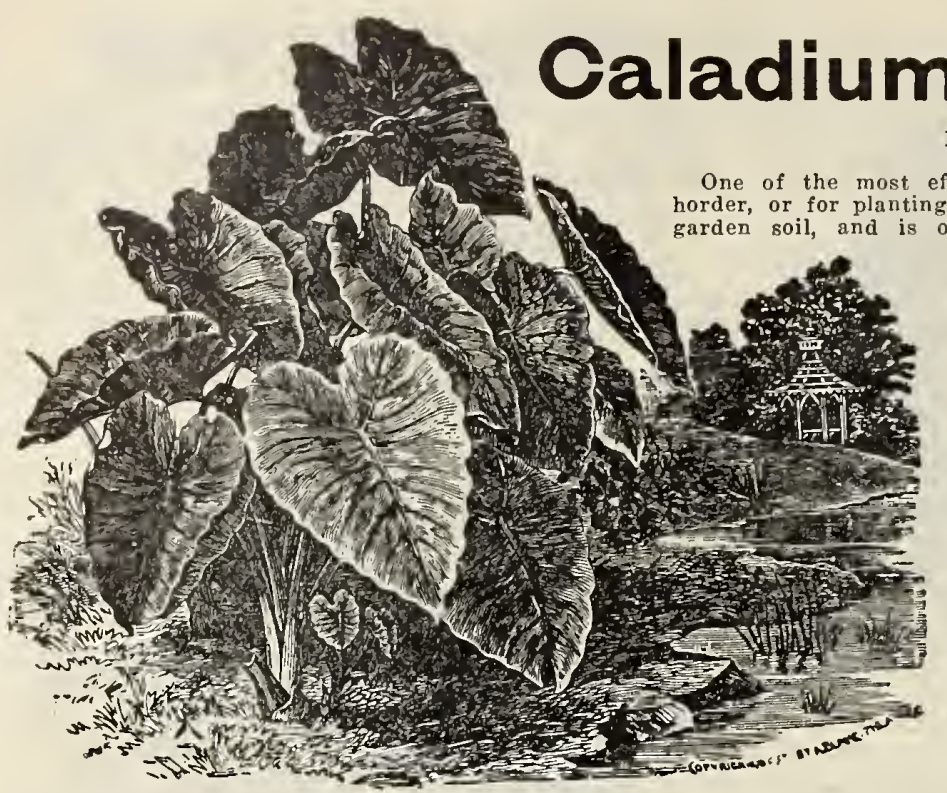

Esculentum

ELEPHANT'S EAR

Caladium Esculentum

\section{LEOPARD PLANT \\ Farfugium Grande}

Immense, clear bright green, leather like leaves, regu larly hloched, and spotted with golden yellow. A very useful decorative pot plant. Of very easy culture. Easily wintered over in cool cellar. Very desirahle and attractive. Price, nice plants, 25 cents each.

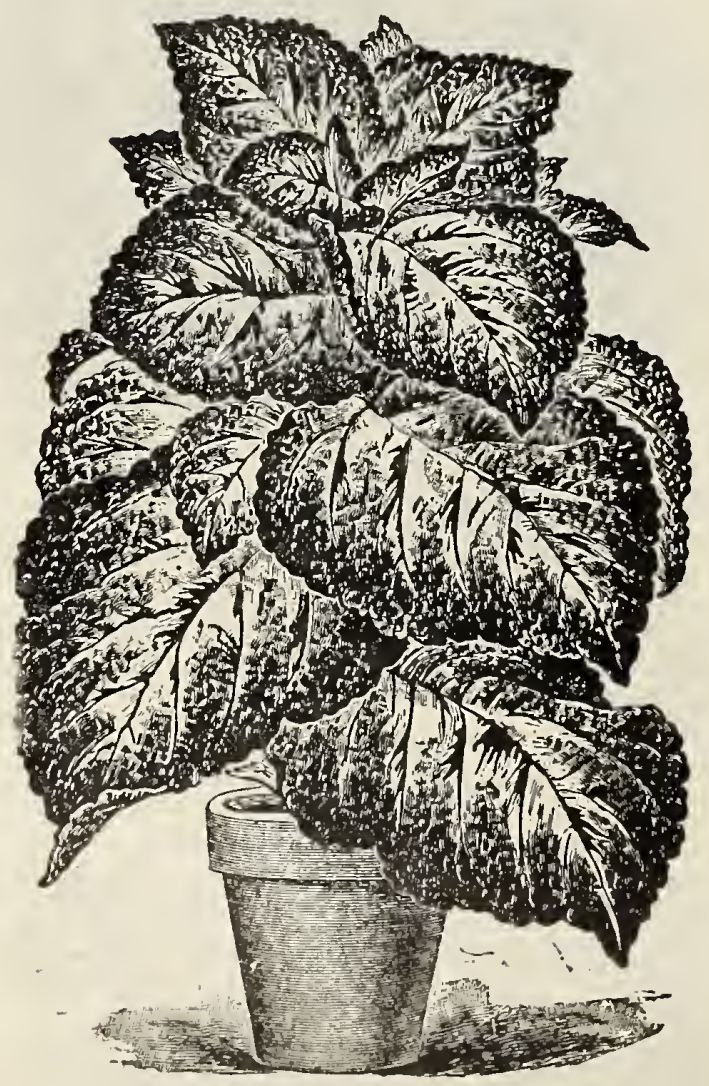

Winter Gem Coleus hlooms are pure white and measure two and one-half inches across and are delightfully fragrant. The flowers are extremely fashionable, and for this reason, together with its ease of culture, we feel sure of a lively demand. Price, one year size, 15 cents each; extra large, 75 cents, $\$ 1.00, \$ 1.50$ and $\$ 2.00$ each.

\section{JASMINE, GRAND DUKE}

This jasmine is very easily grown, even small plants hearing a profusion of very douhle cleamy white flowers. having a delicious perfume. It can he stored in a dry cellar in winter. Price, 15 cents each; larger, 30 cents each.

\section{CONFEDERATE JASMTNE}

This makes an elegant hard wooded climber, or can be trained to hush form. It hears large bunches of pure white flowers, with the most delicious Jasmine perfume. Price, 15 cents each.

\section{NEW JASMINE, MAID OF ORIEANS}

A very attractive new sort, with good sized double flowers, hlooming profusely all summer; shining pale green foliage. Easier to handle than other Cape Jasmine. Price, nice plants, 10 cents each; larger, 25 cents each.

\section{COLEUS}

WINTER GEM. Has broad leaves that often measures eight inches across, heautifully marked with yellow and hrightest crimson. The prettiest foliage plant we know. Stock in fine condition. Price, 10 cents each. Specimens, 25 and 50 cents each.

TRAILING QUEEN, Elegant fringed leaves hlending from pink to crimson, finely scolloped edges. The plant is half trailing or running and is well adapted for win. dow hoxes, haskets or vases. Price, 10 cents each; per dozen, $\$ 1.00$.

\section{NEW BEDDING COLEUS}

Coleus represent more colors in their variegation than any other plant. Whether grown as single specimens or in masses or ribbon lines they are equally attractire. (ne easiest culture and well adapted to our each; 30 plants for $\$ 1.00 ; 100$ plants for $\$ 3.00$

\section{CLERODENDRON BALFOURI}

\section{We} one of the most satisfactory plants for window culture now known. It is a vigorous, rapid, healthy grower, and produces an ahundance of hlooms which are bright crimson surrounded hy pearly-white petals, producing a striking contrast against the dark green foliage. It can be used for a fine specimen pot plant, and can he grown to fine form by cutting off the ends of the growing shoots. A partially shaded position is conducive to rapid growth. Price, 16 cents each. 


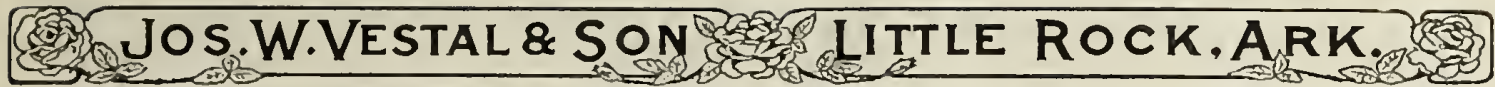

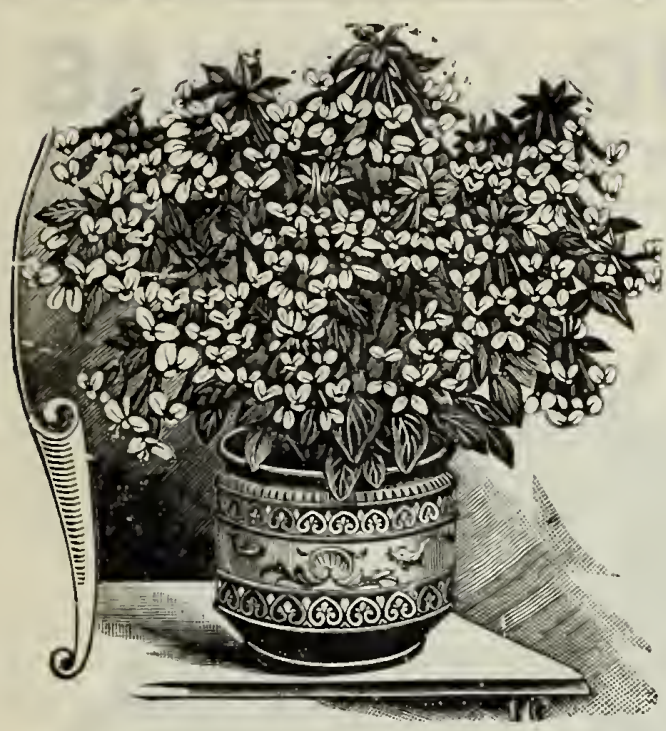

Cuphea Llavea

\section{Cuphea Llavea}

The flowers are tubular in shape, one and one-half to two inches long, and have two bright scarlet wings at the end of each flower; the tip of the flower is bright purple; the stamens are pure white; the body of the flower is pes green and is covered with fine crimson hairs like a moss rose. The plants are always in bloom when given proper care. It makes an elegant appearance when potted or in the open ground. Price, 10 cents each.

\section{CUPHEA PLATYCENTRA Cigar Plant}

Scarlet, pendulous flowers; neat compact habit; constant bloomer. Price, 5 cents each.

\section{NEW GODFREY EVERBLOOMING}

\section{DWARF CALIAA LILY}

This new dwarf Hybrid is a true everblooming variety. It grows about eighteen inches high and will produce three times as many blooms as the old White Calla. The flowers are equally large and perfect in form. Very much whiter and delightfully fragrant. When properly treated it will grow and bloom the whole summer and winter; though, of course, a short season of rest is always beneficial. Price, flne growing plants, 25 cents each; three for 65 cents.

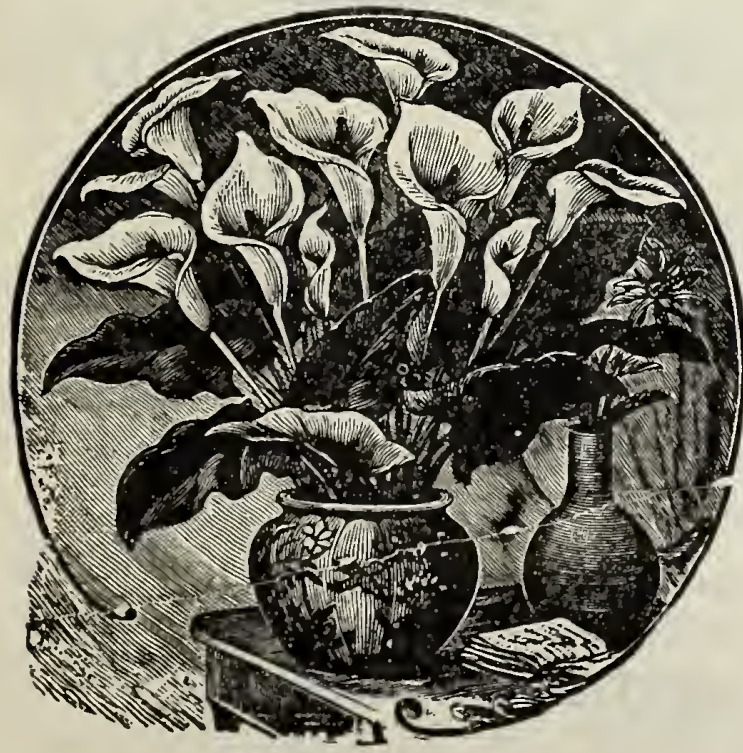

White Oalla Lily

\section{CESTRUM PARQUI}

Night Blooming Jasmine

A beautiful tender shrub of easy cultivation, producing beautiful white flowers in clusters, and in the preatest profusion; overpoweringly sweet at night. Price, 10 cents each.

\section{CESTRUM DIURNUM}

\section{Day Blooming Jasmine}

A handsome quick growing evergreen shrub, producing quantities of sweet scented white flowers, $\nabla$ aluable for cut flower work. Price, 10 cents each.

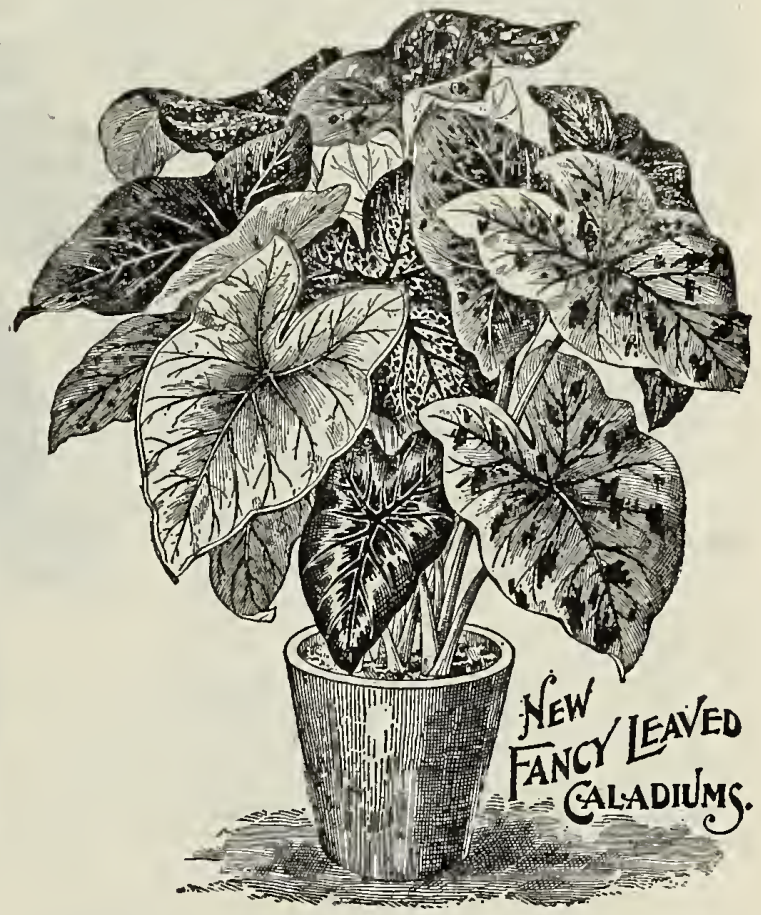

\section{Fancy Leaved Caladium}

These plants are especially valuable for decorating conservatories, window boxes, floral baskets and as specimen plants. They are never as large as Esculentum, but the brilliant of of leaves cannot be obtained in any other class of plants For arranging floral baskets or table decorations, the leaves are quite as handsome as any flower. Price, 25 cents each.

\section{NEW YELLOW CALLA}

\section{Mrs. Roosevelt}

This is the finest Yellow Calla yet produced. Flowers large and clear bright yellow; foliage deep green, finely spotted pure white; fine for house culture. Price, strong blooming size bulbs, 35 cents each; three for $\$ 1.00$.

\section{The White Calla}

\section{Or Ifly of the Nile}

This is one of our most highly $\nabla$ alued house plants for winter and spring bloom. It should be dried off and kept dormant from the middle of June until September, then potted in good rich soil in four or five inch pot and given plenty of heat and moisture. Price, 20 cents each; two for 35 cents.

\section{SPOTTED CALLA LILY}

The leaves are beautifully spotted, yellow and creamy white, making a handsome plant. Should be kept dry in winter and started in April. Price, 10 cents each; three for 25 cents. 


\section{EVERBLOOMING CANNAS}

\section{AMERICA'S MOST POPULAR BEDDING PLANT}

This Superb Collection Includes Only the Very Choicest Sorts and Widest Range of Color

For a gorgeous display and continuoua bloom all summer long until frost, there is no plant ean ecjual the Canna. They make the most magnificent show in large rowa or beds.

\section{KING HUMBERT}

The King of Crimson Cannas

The finest and most beautiful Crimson Canna yet introduced: far supcrior to all others. This splendid Canna, onc of the very best, has been thoroughly tested in different parts of the coun. try and is pronouneed by leading experts, as well as amatcurs, the finest and most beautiful Crimson Canna yet produced. The foliage is bronze, with brownish green stripes, large, thick and leathery: in fact the finest foliage of all and leathery; in fact the finest foliage of all cents each.

\section{BRANDYWINE}

A beautiful bronze lcaved Canna; a healthy, vigorona grower of four to five feet. Makes a luxurious growth of dark bronze foliage and a magnificent display of fine large flowers. Color is intense vinous red, beautifully dappled 'with deep crimson; two or three petals are sometimes narrowly edged with bright gold. Price, 15 centa each.

\section{MARTHA WASHINGTON}

The most showy and handsome of all pink Cannas. We ask particular attention to this new variety, which is undoubtedly one of the most showy and handsome of all pink Cannas. Its enormous inasses of flowers and exquisite color attract immediate attention. The flowers are extra large, having broad, well rounded pet. als, frequently two inches across. The color is bright rosy pink, elegantly mottled with rose, shaded rich golden yellow at throat. Your collection will not be complete without Martha Washington. Price, 10 cents each.

\section{FLAMINGO}

A superb variety with trusses of immense size, nearly A super individual flowers are very large, nearly four inches across, individual flowers are very large, nearly four inches across, son. Plant sturdy and vigorous, rarely exceeding four feet in height. Price, 15 cents each.

\section{BURBANK}

Flowers are gigantic in size, upper petals spreading seven inches. Inner part of petals show fine crimson spots; all of the rest of the flower a beautiful, rich ca. nary yellow. Price, 10 cents each.

\section{EGANDALE}

The finest, freest and earliest of all the dark leaved varieties; Howers very much the shade of scarlet found in "Triumph," and much the same shape; has no supe rior. Price, 15 cents each.

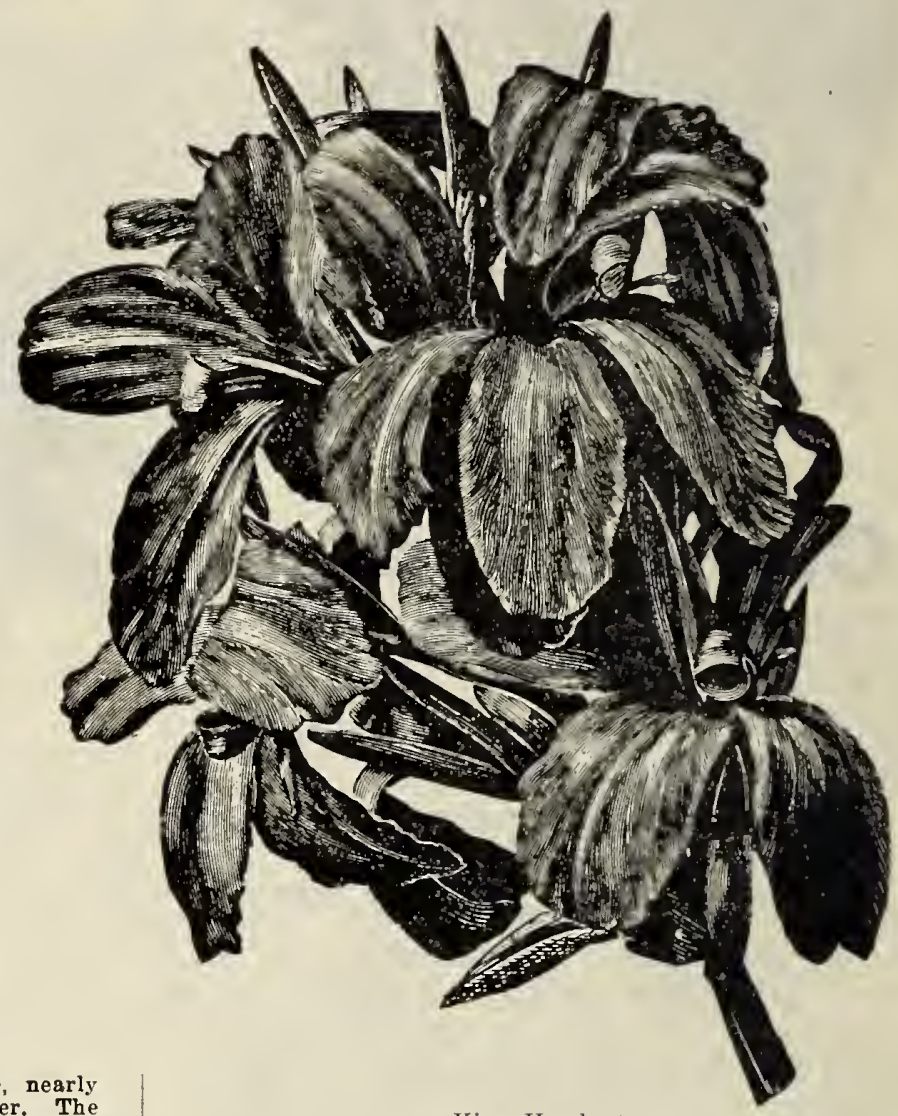

King Humbert

\section{ALEMANNIA}

The giant of all Cannas. Produces the largest flowers. The outer petals are scarlet, with a very broad, golden yellow border. Inside of bloom is scarlet and dark red. Price, 10 cents each.

\section{WILLIAM SAUNDERS}

Flowers are bright scarlet, produced in great clusters, often a foot across. and each on branching stems about four feet high. Individual fiowers, often five inches across, of remarkable substance and durability. It is a strong, vigorous grower and self-cleaning, which meana flowers always fresh from June till frost. Price, 20 cents each.

\section{A MOST REMARKABLE OFFER}

For only fifty cents we will send Six Choice Cannas, our selection, from the cream of

all the new raricties; " fine collection that will surely please you. By expresa only;

too large to send by mail.

SIX STRONG GROWING PLANTS, FOR ONLY FIFTY CENTS

FOR ROUND

CANNA BEDS

Diam. Required

Ft. Plants

$\begin{array}{rr}7 & 19 \\ 10 & 37\end{array}$

$13 \quad 61$

\section{SPECIAL PRICES ON VARIETIES OF CANNAS}

IN QUANTITY FOR BEDDING

Order 10 cent Cannas at 80 cents per ten. $\$ 7.50$ per 100 ; order 15 cent Cannas at $\$ 1.20$ per ten, $\$ 11.00$ per 100 ; order 20 cent Cannas at $\$ 1.50$ per tell, $\$ 12.50$ per 100 . 


\section{VENUS}

An exceedingly beautiful variety, at once the most delieate in coloring and texture, and as vigor. ons and long-seasoned as any Canna grown. Long. erect stems bear trusscs of large size, perfect form and ever clean freshness. The large, oval petals are exquisitely variegated; warm rose-pink, mottled near center, and elged with creamy white. Price, 20 cents each.

\section{PENNSYLVANIA}

The only pure deep red flowering sort in the Orchid-flowering elass. The flowers are immense, ofteu seven inches across, with petals two and a in splendid branching and profuse blooming habit place it at the head of Orchid flowering Cannas to date. Price, 10 cents each.

\section{WYOMING}

A beautiful Orchid-flowering variety, with rich purplish bronze foliage. Flowers are large as King Ilumbert, and of good substance: bright orange, slightly rimmed and flaked with rose.
Price, 20 cents each.

\section{FLORENCE VAUGHAN}

In color it is of a bright, rich, golden yellow, spotted with bright red; the flowers, which of the largest size, of great substance and of perfect form, are borne in large heads, and in the preatest pro. fusion. The foliage is massive and of a rich green color. The plants rarely exceed from four to five feet in height. Price, io cents each.

\section{MOUNT' ETNA}

Magnifieent dark purple foliage; large, bold, ereet trusses; flower intense brilliant crimson. Price, 15 cents each.

\section{BENJ. F. HOWELL}

This is indeed a wonderful Canna and may justly be termed an improved King Humbert. It is of slightly taller growth and very like King Humbert in flower and foliage-fully equaling that grand variety; in fact, a still frcer bloomer. Price, 20 cents each.

\section{GLADIATOR}

A rugged, strong growing variety, which withstands our summer storms better than almost any other Canna. The flowers are bright yellow, thickly spotted with crim son; blooms profusely. Heads are unusually large and borne on long, strong stalks, with tough, deep green foliage. Price, 15 cents each.

\section{SHENANDOAH}

This fine new Canna is certainly a grand addition to our list of dark foliage varieties, its beautiful pink flow. ers standing out in striking contrast with its rich red foliage. The plant is of a dwarf and compact habit. Price, 15 cents each.

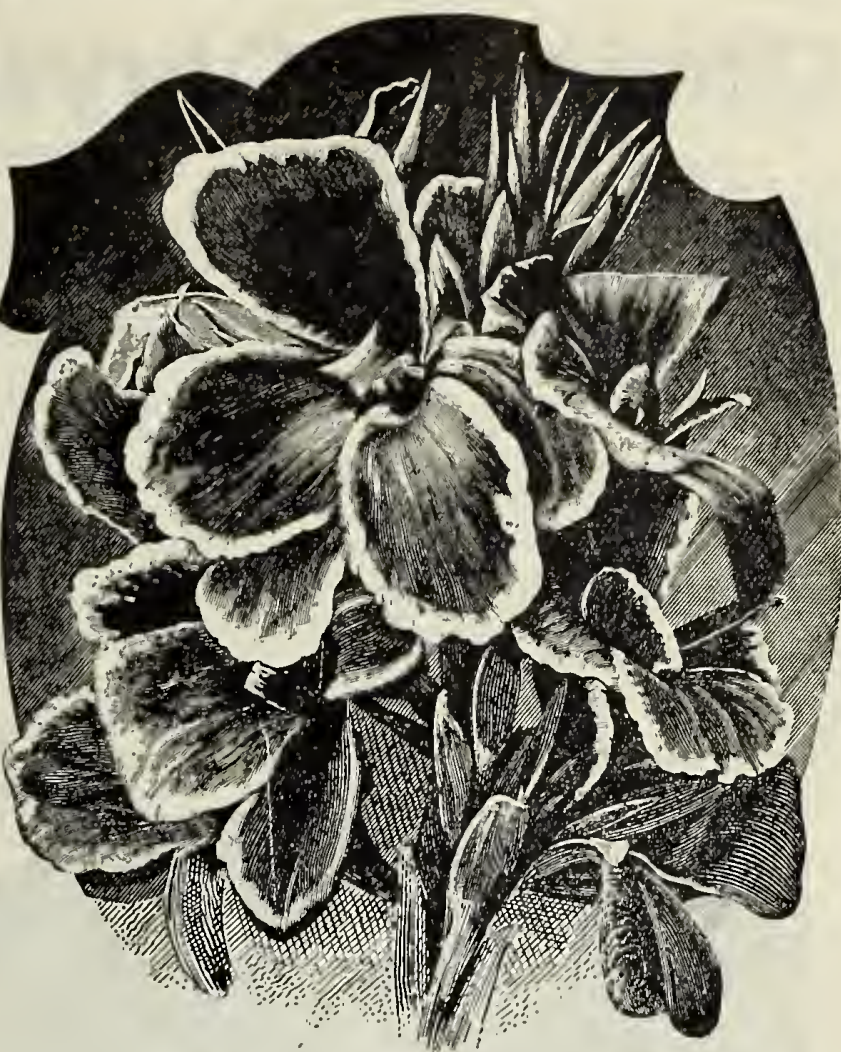

Venus

\section{PRESIDENT MCKINLEY}

Grows about four feet high. Flowers fine clear crim son, with scarlet shadings; trusses large' and shapely, borne well above the foliage. A low, compact grower. Price, 15 cents each.

\section{CHAS. HENDERSON}

Rich crimson flowered Canna. A splendid dwarf, com. pact grower, throwing up direct, compact heads of bloom of immense size. The individual flowers are among the very largest. Color, dark erimson; center of the flowers marked with gold pencilings. Price, 10 cents each.

\section{ELIZABETH HOSS}

Enormous trusses of blooms, spotted on the style of Florence Vaughan, but richer in color. They rival those of the orchid-flowering type in size, but unlike these, it is exceedingly free flowering and does not sunburn. Price, 15 cents each.

\section{Is There a Place on Your Lawn}

\section{FOR A FLOWER BED THAT WILL PRODUCE AN ABUNDANCE OF BLOSSOMS ALL SUMMER LONG?}

It matters not how large it is, nor indeed how small; if you have suitable spot that gets the sunshine plant a bed of Cannas and enjoy the pure beauty of their freslly opened flowers every day from June till frost. Why let the parks monopolize these gorgeous color displays? Why not have them at home?- for you can, easily.

DIRECTIONS FOR LAXING OUT CIRCULAR BEDS

Always use tallest growing varieties in the center, and then carefully grading eaeh succeeding circle, using dwar kinds for the outside. Plant one Canna in center of bed; next, six Cannas eighteen inches apart in a eircular row eighteen inches from center. For each succeeding circle use six more Cannas than were used in the previous circle, and make it eighteen inches farther away from the cen. ter. A bed thus planted will contain one Canna in the center, six in the first circle, twelve in the second circle, elghteen in the third circle, twenty-four in the fourth cirele, etc., and all eighteen inches apart.

COST OF CIRCULAR CANNA BEDS

If you will leave selection entirely to us, we will choose suitable kinds, and send you the right color and proper number for every circle, as follows:

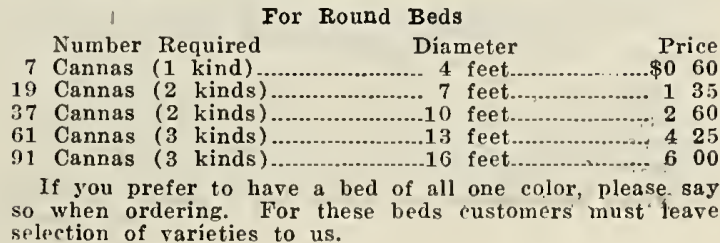




\section{Choicest Chrysanthemums}

Price, 10 cents each; three for 25 cents; sixteen for $\$ 1.00$, except where noted. And where the selection is left to us, we will give twenty for $\$ 1.00$.

OUR SPLENDID LIST OF CHRYSANTHEMUMS is unsurpassed anywhere. We take great pride in keeping it up to the highest standard and excellence. A glance over our splendid list will convince anyone that it is no idle assertion. We have by far the most complete collection of this most popular flower in the great Southwest.

\section{CULTURAL DIRECTIONS FOR CHRYSANTHEMUMS, WHICH, IF FOLLOWED, WILL INSURE SUCGESS}

WHEN TO PLANT. Any time after the ground can be worked, even up to June 20 th, will give you good blooming plants in the fall.

SOIL. Dig the ground deep; put in quantities of manure. The Chrysanthemum is a gross feeder; if fed well the flowers will be large and the plant strong.

DISBUDDING AND STOPPING. When your plant is eight inches high cut back to a height of six inches. Allow your shoots to grow from this main trunk. When these four shoots are four inches high pinch out the terminal bud, and save three or four branches that will spring from each of these limbs. Allow these last branches to attain a height of nine inches, then pinch back for the last time. Allow one bud (flower) to each stem, and that a terminal bud.

WE HAVE THE FINEST AND MOST COMPLETE ASSORTMENT OF "MUMS" IN THE SOUTHWEST-CHEAPEST, TOO
WHEN TO LIFT. In localities subject to hcary frost in October and November plants should be lifted into large pots or boxes by September 1st. After lifting drench thoroughly, and never allow them to suffer for water. Give manure water, if possible, once a week. If protected from frost by sheeting, they need not be brought into the house till well into October, and when brought in place in a room without fire; give plenty of air when not frosty. In cold climate winter in cellar.

BLACK APHIS. Nothing destroys this troublesome in sect so easily as clean cold water dashed on forcibly with a syringe.

Eacli year the taste for Chrysanthemums becomes more exacting, and to meet it we offer only the finest exhibition and over.

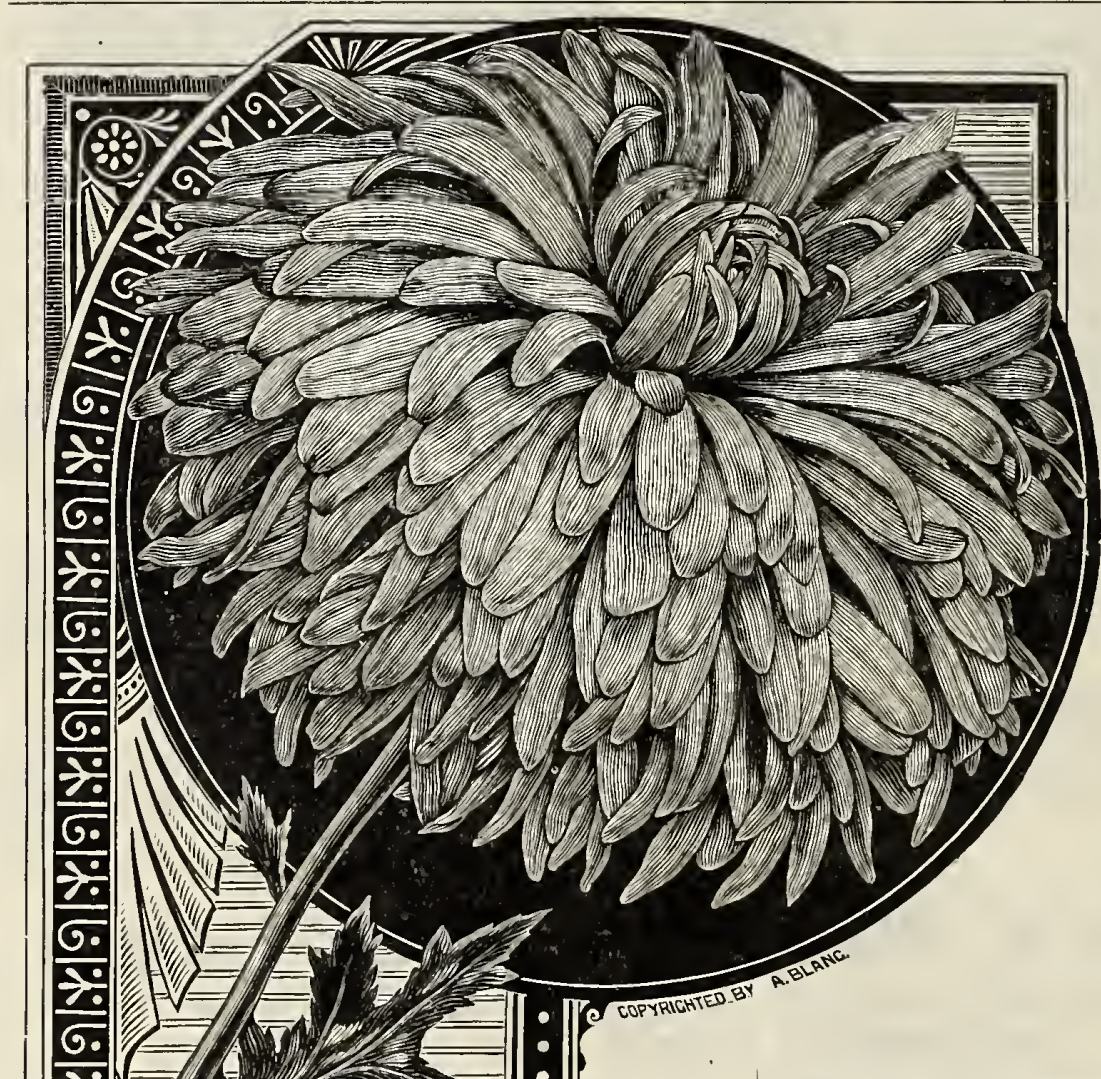

A. J. BALFOUR. A grand Tapanese incurved $\nabla$ a $r$ i e t $y$ Color, rose pink: broad petals of great substance. Fast gain ing first place. Nothing to touch it in color. A pink that is dazzling.

\section{AMATEUR CONSEIL.}

first class, reflexing red velvety texture and large size; shows the color to perfection.

BLACK HAWK. The largest and most beautiful dark erimson scarlet yet introduced; looks like crimson relvet, the very shade so much desired in Chrysanthemums: flowers of immense size on fine stiff stems.

BUFF GLOBE. This enor mous globe shaped flower is identical with its parent, Good Gracious, in everything save color, which is a pale chrome yellow, shading to buff. A fine variety; try it.

COL. D. APPLETON. A very large, deep golden yellow Tapanese incurving; flower of fine finish and form. This is one of the best commercial varieties.

CHRYSOLORA. This new variety can be briefly describ ed as an early Col. D. Appleton, coming in earlier, is of larger size.

CHAS. RAZER. A good commercial pure snow white with a grand stem, and foliage as handsome as Eaton.

DOROTHY GOLDSMITH. A massive reflexed yellow, slightly shaded bronze. One grower has called it a bronze F. S. Valis, which is a good description. This should be a whopper for the biggest flower in the show.

GOLDEN CHADWICK. This is a grand addition to the commercial yellows. A perfect Chadwick, in a good shade of the color; almost as deep as Appleton.

GEORGE W. CHILDS. The flowers are of massive size, reflexed, with broad, stiff petals. Color deep, rich, velvety crimson, with no shade of brown or chestnut.

GOLDEN KTNG. Bright golden yellow of excellent substance, Dwarf habit, with perfect stem and foliage. A perfect golden ball.

DAKOMA. A grand bronze of large size and beautiful foliage all that can be desired.

GIENVIEW. An enormous incurving globe of dark bronze and clear red. Dwarf grower, with stiff stem. A color is very pleasing.

Price, 10 cants ach; throe for 25 conts; sirteen for $\$ 1.00$, except where noted. And where the selection is loft to us we will give twonty for $\$ 1.00$. 


\section{Choicest Chrysanthemums}

Price, 10 cents each; three for 25 cents; sixteen for $\$ 1.00$, except where noted. And where the selection is left to us we will give twenty for $\$ 1.00$.

GETTYSBURG. The color is of the richest velvety crimson. The outcr petals are broad and drooping, and have a lustrous slieen in the sunlight. The form is flat, with drooping outerpetals, which gives it a very graceful appearance.

GOLDEN WEDDING. The flowers are a great fluffy mass of clear golden yellow, sunshiny and glistening, sometimes eight or nine inches across, and without a blemish.

HESTER WHITE. A very popular variety, beautiful in finish; a very easy doer, pure snow white; compact incurve.

HELEN BLOODGOOD. The most meri. torious pink introduced, being the first truc clear pink without a trace or shading of purple or magenta.

INCANDESCENCE. Very large," solid bloom of beautiful form; color, yellow of the deepcst shade and orange bronze.

JAMES THREEFALL. Crimson, bronze reverse; large and of fine form.

IILIAN B. BIRD, This beautiful and unique variety is of an exquisite shrimp pink in color, producing flowers which of ten measure ten inches in diameter; large tubular petals of perfect form. This variety has taken prizes wherever exhibited.

MART DONNELLAN. A splendid golden yellow, incurved, exceedingly broad petals of great substance, which in arrangement are most beautiful. It is $s 0$ beautiful in color, so exquisite in form, and of such large size that it is sure to be strong competitor in the exhibition classes.

M. ANTONIN MARMONTEL. One of the most besutiful of Chrysanthemums; the color is rosy crimson; form, an incurbing globe; a beauty.

MRS. O. H. KAHN. A beautiful bronze, with mahog any shadings. An absolutely reliable variety; always any shadings fine.

MRS. ROBERT FOERDERER. A fine globular flower of unique color, soft creamy yellow, with light amber shadings; broad incurving petals and ideal stem and growth.

MRS. PERRIN. Brightest shade of pink yet produced in the Chrysanthemum. The flower is of globular, incurved form, with fine satin finish.

PRESIDENT TAFT. Japanese incurved, petals of the purest white, which closely incurve, forming a huge, glistening ball,

NORFOLK BLUSH. There is nothing like it in color, which is a deep reddish salmon upon opening, and grad. ually changes to a soft shrimp pink when fully finished. The flowers are of the largest size.

PERFECT TILLAR. One of the largest blooms that we have cver seen, botll deep and broad. Color, bright crim. son, with gold reverse.

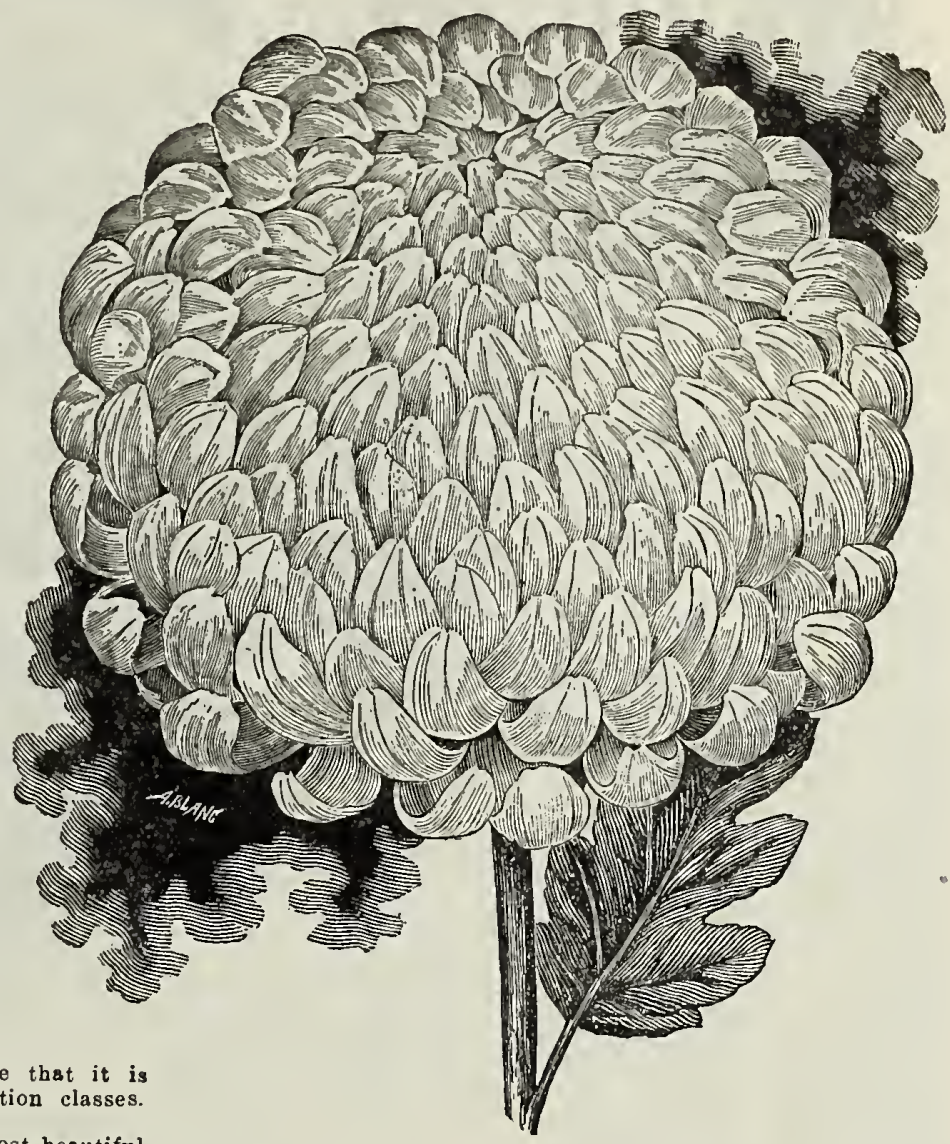

R. F. FELTON. Deepest buttercup yellow; grand in every way; apparently faultless. A sort with splendid stem, beautiful foliage, large incurved flower.

ROSE POCKETT. Another flower that for collections will be found invaluable. The color varies from bronze to old gold, and the petals stand out straight, showing two colors to the very best advantage.

SILVER WEDDING. The purest white, with broad, reflexed petals, forming a bold, handsome flower, seven inches and over in diameter.

TIMOTHY EATON. One of the largest, and a winner of every cup and prize for which it was entered. Purest white, of true globular shape.

WM. DUCKHAM. Very large Japanese incurved of a pleasing pink. Vigorous in growth, stout in stem, well clothed with heary foliage, and crowned with a flower eight inches in diameter. Medium early.

WHITE CLOUD. In the entire Chrysanthemum family there is no grander white variety, no matter when it blooms. Immense incurving, broad channeled petals of

Price, 10 cents each; three for 25 cents; sixteen for $\$ 1.00$, except where noted. And where the selection is left to us we will give twenty for $\$ 1.00$.

\section{AMATEUR COLLECTION OF CHRYSANTHEMUMS 25 FOR $\$ 1.00$}

We aro prepared to grow Chrysanthemums in immense quantities, and we propose to offer them at a price that should induce everybody to grow them. Don't imagine that because they are cheap the plants must be small and worthless, and of very inferior varieties. Everybody knows that it costs just as much to give a poor variety as on and worthless, and POOR ONE IN THE ENTIRE COLIECTION. 


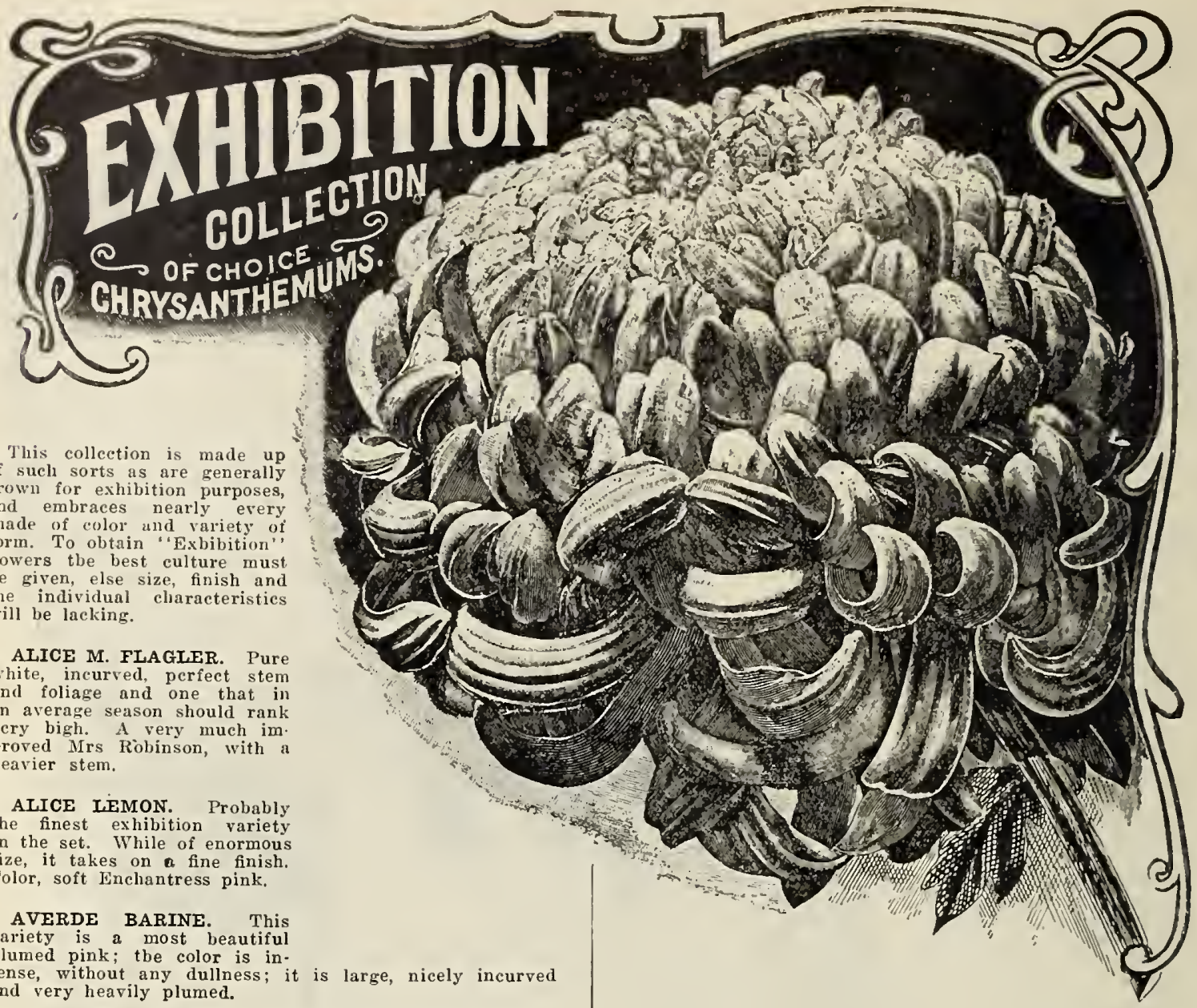

AMI BEAUCHANNE. Color, brilliant old gold, cbanging to pure gold; very big; a fine exhibition novelty.

DRIFTWOOD. The nearest description for tbe color is chamois, intermediate between apricot and primrose. Perfect stem and foliage, double from any bud.

DICK WITTERSTAETTER. An intense shade of red; not as dark as most of the red varieties, approacbing not as dark as mo scarlet.

EMBERTA. A pure snow white incurving; of fine size with claw-like petals.

GOLDEN GEM. There is no finer commercial yellow than tbis golden yellow novelty promises to prove. It is perfectly round, of a most brilliant color, substantial in build and texture, with bandsome foliage and stiff stem.

GLEN COVE. Outer petals broad and reflexing. Color, latvender pink of a very pleasing shade.

GLACIER. Pure white; we have never seen anything larger and more impressive for the exhibition table in its color. It is enormous in diameter, dcep in build, very perfect in form.

HOWARD GOULD. The florets are long and grooved and the flower builds up into an enormous globe, splendid in form and substance. The inside of the petals is of bright, golden chestnut, with a reverse of pure, deep gold.

IENOX. The largest yellow known; in fact tbere are but a few in our large collection that equal it in size. Beautiful, loosely incurved and a bright pleasing sbade of yellow.

PRICES.-ANY VARIETY FROM THE EXHIBITION COLLECTION OF CHRYSANTHEMUMS, 15 CENTS EACH; $\$ 1.50$ PER DOZEN. A FULI SET OF THE TWENTY VARIETIES IN THIS COLLECTION FOR \$2.00. WITH THIS SET YOU WOULD HAVE NO TROUBLE IN WINNING THE BEST PRIZES IN ANY CHRYSANTHEMUM SHOW. 
JOS.W.VESTAL \& SON R

OCTOBER FLOWERING CHRYSANTHEMUMS

Mauy people sre deprived of the benefit of their Clarsanthemums every year by the untimely early frosts, and to accommodate these people we have prepared a collection of early kinds that can be had to perfection early in october, hefore any danger of early frosts. We offer this year a finer collection than ever, and one we believe is unequaled for nutdoor plating. Some of the vintetics have flowers as large as the fine show flowers grown under glass. Amatcurs who lave no roon for Clarysanthe. mums under flass will be de cents each; three for 25 cents: sixteen for $\$ 1.00$

A D V A N C E. Pure white when fully expanded, showing a creamy center when semideveloped. This is the earliest large white rariety known.

BRUTUS. Orange and red. Straiglit petals, forming a half lobular flower. Good color. Nice for exhibition collections.

CLEMIENTINE T O U S E T. (Early Chadwick.) A very large, loosely incurved bloom, flowering in early October. Color, pure white from early buds, terminals sometimes tint ed pearl
bud.

DONATELLO. Bright yel. low, ball shaped, of great sub. stance, fine foliage, with very wiry stem.

GLORIA. A beautiful light pink, same as seen in the En. chantress Carnation. Stem and foliage unsurpassed.

GOLDEN GLOW. We cut the first flowers on October loth, seversl days before any other large yellow was ready. and had perfect flowers to cut a month later. This grand vsriety will be invalusble for early cut flowers.

ROSIERE. A fine double, deep rose pink that, avoiding the common fault of most early pinks, does not fade. It is of dwarf habit, with heavy foliage and immense blooms seven and one-half to eight inches across.

UNAKA. A fine incurved bloom of a pleasing shade of pink, and maturing the first week of October, places it foremost among the early pinks. In fact, there is no with it at this date.

YELLOW TOUSET. A yel low sport of the populsr early white, identical with it in every way except color.

\section{DECEMBER FLOWERING CHRYSANTHEMUMS}

To those hovin $a^{\circ}$ small mreenhouse, or arce prepred to rive them protection in any way, the following varieties can easily be had in flower at the Christmas holidays:

BELFAST. An immense, graceful bloom; waxy white, occasionally tinted pink; growth, habit, stem and foliage imply perfect.

DECEMBER GEM. A ball-shaped Japanese white, with pink stripe on edge of petals, giving a pink or pearly tint to the bloom. Stock planted early in Junc gave very perfect blooms six and one-half inches in diameter on December 1. Later buds will give succession to Christmas. Strong stem, with ample foliage.

GOLDEN EAGI.E. After thorough tests this new Chry santhemum has proved to be one of the Anest yellows ever ent out. It is a flower of immense size and great depth.

HELEN FRICK. Color a beautiful clear pink (like the Mermet Rose), slightly deeper at the center. The petals have a solid, waxy texture.

LAVENDER QUEEN, An immense solid flower, very full and compact; outer petals reflexed, center petals erect, forming a flower of great depth. It is a lovely color, soft, silvery lavender pink, decidedly distinct from any other pink.

YANOMA. A very late pure white; petals long and loosely arranged. One of the best.

PRICE OF DECEMBER FLOWERING CHRYSANTHEMUMS, 15 CENTS EACH; SET OF TWELVE FOR $\$ 1.00$.

MISS MIRIAM HANKEY. Japanese incurved, bright mauve pink of enormous size; splendid síze and stem and good foliage.

MLLE. JEANNE ROSETTE. An enormous pink, very full and compact. A fine Chrysanthemum for late cutting. The stem and foliage are perfect.

OSPREY. A very late white of medium size, of ab solutely perfect form, like a Dahlia. This variety will be the largest flowers cannot be used.

THANKSGIVING QUEEN. In form, an improved and magnified Silver Wedding, being larger and more double. Color, creamy white, and maturing November 20 , just right for Thanksgiving use. Stem so strong as sesrcely to require tying.

WHITE HELEN FRICK. Those who appreciate the late pink variety, Helen Frick, will be pleased to know a
white sport has been established. In the early stage of development they show some trace of light pink, but when mature are pure white.

WINTER CHEER. Beautiful jncurving pink, perfect shape; a very easy variety to handle and always popular. 


\section{SELECT LIST

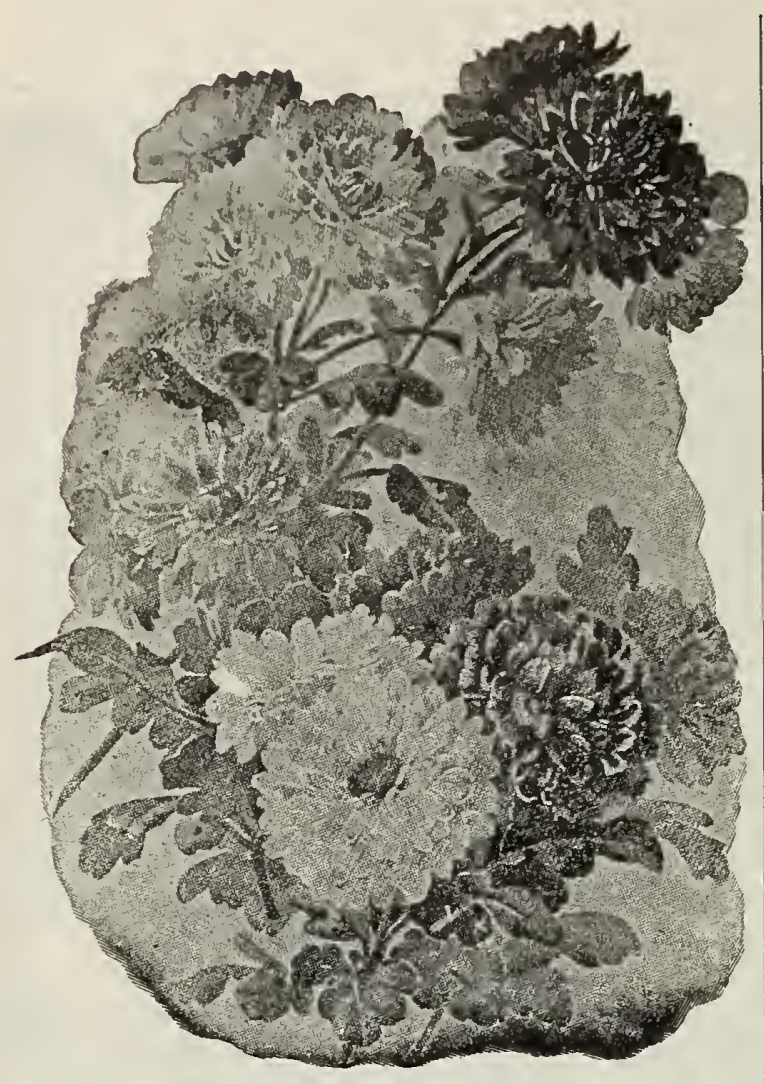

\section{SINGLE VARIETIES}

This type, although long ignored and in many places almost forgotten has been recently shown in fine form and now no exhibition will be complete without its Classe for Singles. For bush plants, decorative pot plants and table decorations, the Singles cxcel, and when well grown they displace and command more admiration than any of the large flowering types.

ANNA. Pure white, belongs to the true single section, having but one row of petals. Fine for pot plants.

ARLEE. A rich, golden amber, of dwarf, sturdy growth, excellent either as a pot plant or for cutting. Large flowering.

CATHERINE LIVINGSTONE. A pleasing shade of lavender pink, strong growth, producing fine sprays. Large flowering.

ITASKA. The incurving petals give the flowers the appearance of pond lilies, and are a most pleasing shade of pink.

LILY GODFREY. Medium size, soft, rosy lavender. LITTLE BARBEE. Clear canary yellow, exceptionally large sprays of medium sized flowers.

HILDA WELLS. Beautiful Tuscan red, with a light yellow tinting at base of petals.

MERSTHAM JEWEL. Rosy terra cotta, with golden points and center; a glorious variety; arrangement on the spray cannot be improved.

MRS. ALICE BROWNSON HUSTON. Daybreak pink; quilled in center, very fine.

MRS. J. A. PETERSON. White, medium sized flower with petals half way quilled. Quilled part of petal delicate pink.

PETER PAN. Fawn color. Has sprays of flowers about nine inches long, with twelve or fifteen dainty star-like flowers on the stem, all opening at the same time, forming a natural lady's spray.

RED LIGHT. This belongs to the large flowering section. Its freedom of bloom and pleasing shade of crimson induce us to offer to the trade. We consider this the best ingle red.

SYLVIA SLADE. The showiest of all the singles, the flower like a giant Cineraria; color, rosy-garnet, with broad white ring around the disc.

Price, 10 cents each; three for 25 cents.
These beautiful small flowered varieties are again coming to the front, and are certain to become popular for outdoor bedding purposes. They are absolutely hardy, and produce an abundant, almost lavish, profusion of blooms, and the plants lend a coloration to the garden just at the time when other plants have been destroyed by frost. Frost does not materially affect the flowering. The collection embraces all the leading colors, and, with but a slight covering of leaves or coarse stable litter during the winter, will take care of themselves after once planted.

ACTо. Incurving, dahlia-like petals. Bright rose, with light reverse.

ALMA. A beautiful pink variety; flowers large for a Pompon. A beauty.

BABY. In a class quite by itself; a fine grower, with dainty foliage and stiff stems. Solid little Howers, with curiously folded petals; very late.

BABY MARGARET. Small and compact in form, with flowers twice as large as Baby, on longer stems. Pure white. Very useful and substantial.

CLORINDA. Semi-dwarf, producing erect sprays of an even shade of bronze.

DIANA. A fine pure white.

HELEN NEWBERRY. Two inches in diameter, high, rounded flowers of purest white, maturing Thanksgiving to Christmas, when most Pompons are gone.

KLONDIKE. Most beautiful yellow in the family: extra fine.

QUINOLA. Stiff stemmed, golden yellow; a favorite.

RUFUS. Crimson maroon; very fine.

SNOWDROP. Pure white; small flowers; very profuse bloomer.

\section{ANEMONE FLOWERED CHRYSANTHEMUMS}

The Anemone Flowers, consisting of one or more rows of flat or tubular ray florets, with shorter quilled or tubular disc florets of the same or a distinct color, are being grown in sprays for artistic floral arrangements.

GARZA. Single row of broad ray petals; well formed center. White, tipped yellow. It is specially adapted for bush plants.

MRS. AUGUST KNAB. New 1909. Creamy white, with large honey-combed center.

SATISFACTIO. Chrome yellow, suffused with gold and amber; trumpet-like florets.

SURPRISE. Forked and hooked guard petals; high center; pink florets. The best.

Price, 10 cents each; four for $\$ 5$ cents.

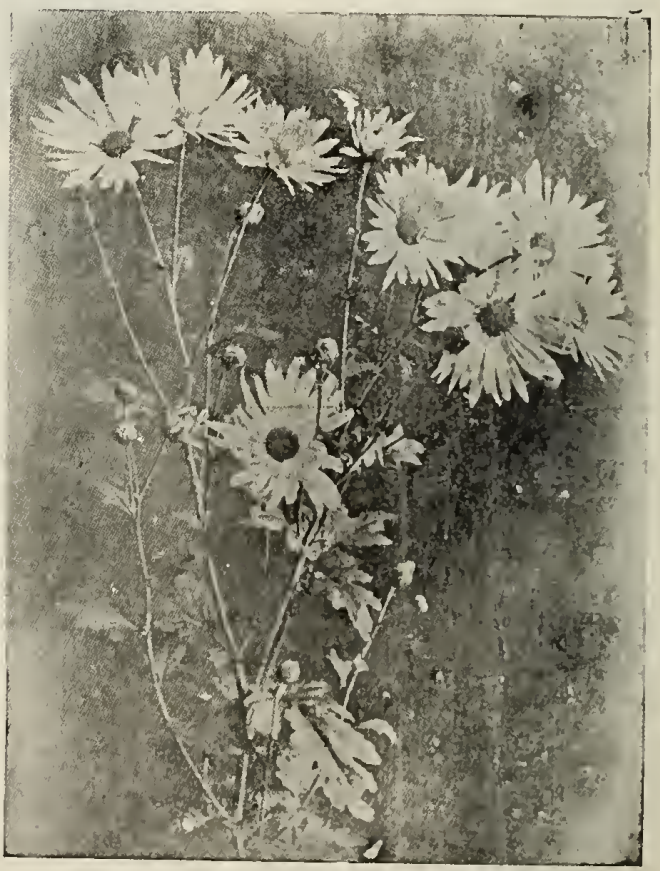

Single Flowered Ohrysanthemums 
VESTAL'S NEW LARGE FLOWERING

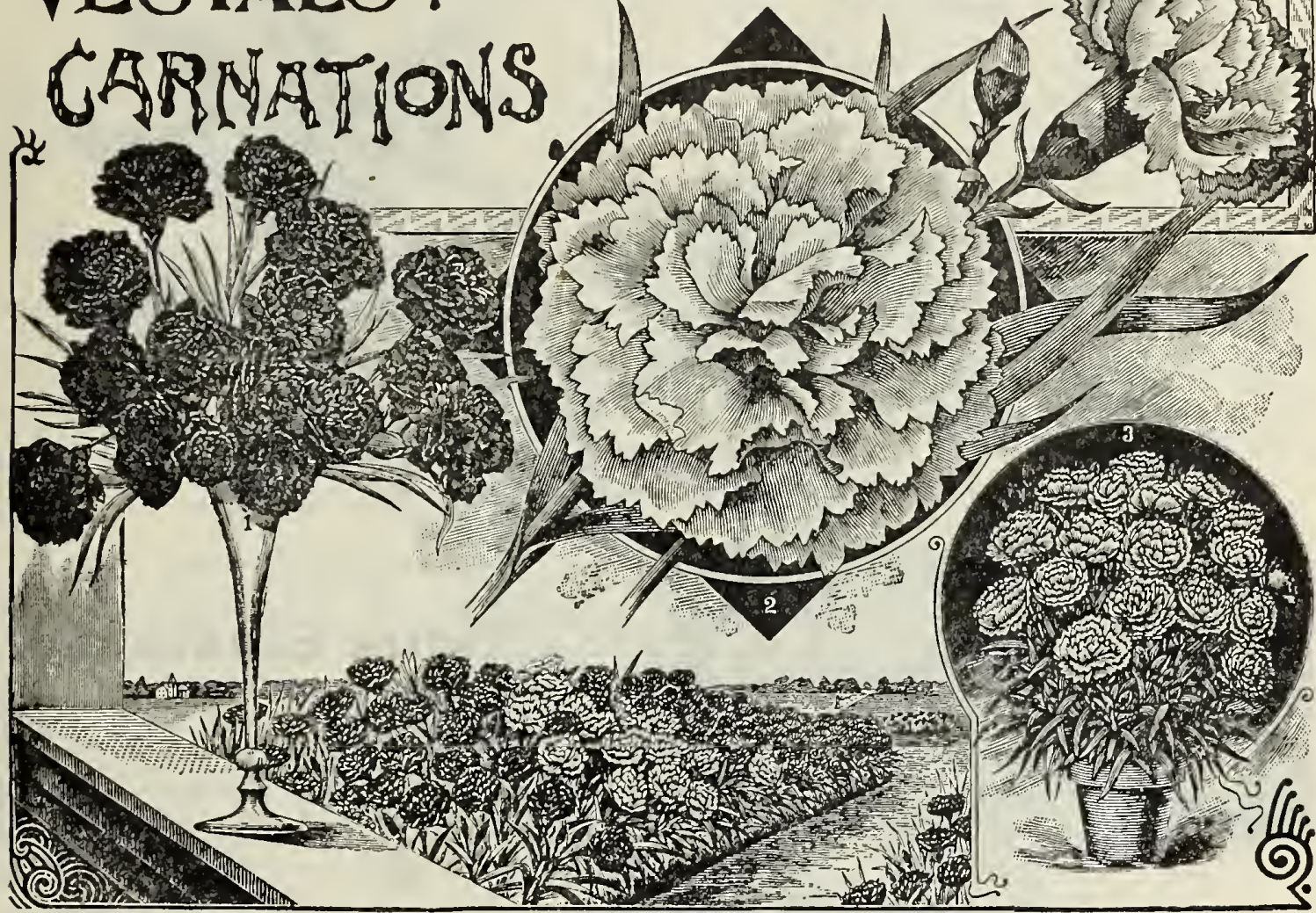

\section{CARNATIONS}

Seemingly tbere is no end to the popularity and demand for these cbarming flowers; few orders coming to our fles but call for some varieties or colors of Carnations. Their simplicity, beauty of form, vivid coloring and spicy scent attract where other and more elaborate flowers are unnoticed or rejected.

PRICE, 10 CENTS EACH; SIXTEEN FOR $\$ 1.00$.

\section{ENCHANTRESS}

One of the grandest carnations of any color; an ex quisitely delicate shade of shell-pink, deepening toward the center. Blooms early and continuously.

\section{HARLOWARDEN}

The largest and best of its color, a bright dazzling crimson. Flowers often measure three inches in diameter, and are well supported on long stiff stems. A won derfully free bloomer, always full of buds.

\section{VICTORY}

Exceptionally satisfactory and useful as a cut flower, owing to its great stability, its nice long stems, and the prodigality of its bloom. Color, brilliant scarlet.

\section{MAY DAY}

Has probably made the best record of any novelty of the season. A Carnation of an exquisite shade of satinpink; has a fine stem, strong calyx, and is probably the freest bloomer extant.

\section{ELDORADO}

Beautiful, clear golden yellow, finely penciled with red; lovely full flowers, exquisite perfume.

\section{THE BEACON}

A splendid new red that blooms tbrougbout a long season. Flowers are gracefully formed, and will average from two and tbreequarters to three inches in diameter. Color, scarlet, witb a brigbtening dash of orange.

\section{ROSE PINK ENCHANTRESS}

A lorely rose-pink shade of color put on by the old favorite "Encbantress." Sbows same practical, wideawake habit of growth and trustwortby blooming qualities as its parent.

\section{WHITE ENCHANTRESS}

One of the best whites yet produced, of pure quality. large size and immense production.

\section{WHITE PERFECTION}

All that its name implies. Bloom is abundant, of large size, and immaculate whiteness.

\section{BLEEDING HEART \\ DIFITA SPECTABITIS}

These pretty spring bloomers, with their graceful, droop ing sprays of beart sbaped pink and white flowers are very ornamental, and bloom freely early in the season. The plants, being hardy, increase in size and bloom from year to year, and should bave a place in overy garden. Price, 20 cents each; three for 50 cents.

\section{CARYOPTERIS}

MASTACANTHUS. (Blue Spirea.) A handsome bardy perennial; grows about tbree feet bigh and produces rich lavender-blue flowers in great profusion the whole lengtb of its branches. A valuable plant either for bedding or pot culture, blooming continuously from early in September until cut by frost. Price, 15 cents each; $\$ 1.50$ per dozen. 


\section{JACK AND THE BEAN STALK VINE}

The Famous Chinese "Kudzu."

In three montlis this wonderful Chinese vine progresses as much as most vines do in five years. Adaptable to porches, arbors, fences, rockeries, old trees, etc.

Like the magic Bean line of the fairy tale, this wondrons bew vine, with orclinstry treatment, will grow 70 feet in one scason, turning crerything it covers into leafy lovliness, and filling the air with the fragrance of its large clusters of Wistaria-like blossoms.

If you wish a vine that will grow anywhere in the best or poorest soil, then plant the Chinese Kudzu. It will fourisl where nothing else will grow, and will last for twenty.five years or more. The large bold leaves of the briohtest of purple Wistaria-like flowers, six to seven inches long. are deliciously fragrant, but its greatest feature is it wonderfully strong growth ( 12 inches in a day), which makes it invaluable for rapidly covering arbors, fences, porches, dead or old trees, rockeries, etc.

Price, good plants, 25 cents each; three for 60 cents. Extra strong plants, 40 cents each; three for $\$ 1.00$.

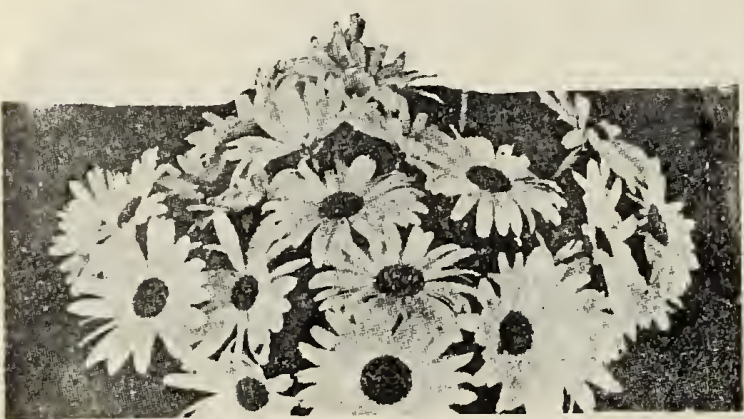

Shasta Daisy

\section{Shasta Daisy}

In growth the plants are as strong as a common field Daisy, very tall, well branched, with fine cut foliage and huge white flowers borne in profusion, on long stiff stems. The flowers are pure white with gold center, petals very long and center soft and velvety. It is a very pretty hardy plant and one of the novelties that has come to stay. Price, 10 cents each; three for 25 cents.

\section{FEVER FEW, LITTLE GEM}

This variety surpasses the old variety in every respect. It is very dwarf, growing only from eight to twelve inches high. The flowers are larger and of more perfect form, and of the purest white and of free flowering habit, the plant being perfectly loaded with blooms. Price, 5 cents each; 50 cents per dozen.

\section{AGATHEA COELESTIS} OR CELESTIAL'DAISY

The flowers are a delicate sky blue with a yellow disc. It is certainly a charming plant. Dwarf growing, no over a foot to eighteen inches in height, and the bushe fairly swarm with its lovely blue blossoms. The cut flower stores in the cities use them by the linudreds of thousands. Blooms from November to June.
sirable. Price, 10 cents each; three for 25 cents.

\section{DUSTY MILLER}

Almost too well known for a description. This is the old Dusty Miller used for cdging beds of Coleus, Geraniums, Cannas, etc. Leaves silvery white. Price, 5 cents each; 60 cents per dozen.

\section{ENGLISH IVY}

A splendid evergreen climber, with dark glossy green leaves clings firmly to stone or brick walls, without trellis or support, covering them closely with its splendid foliage: very desirable. Price, 15 cents each; large size, 25 cent each.

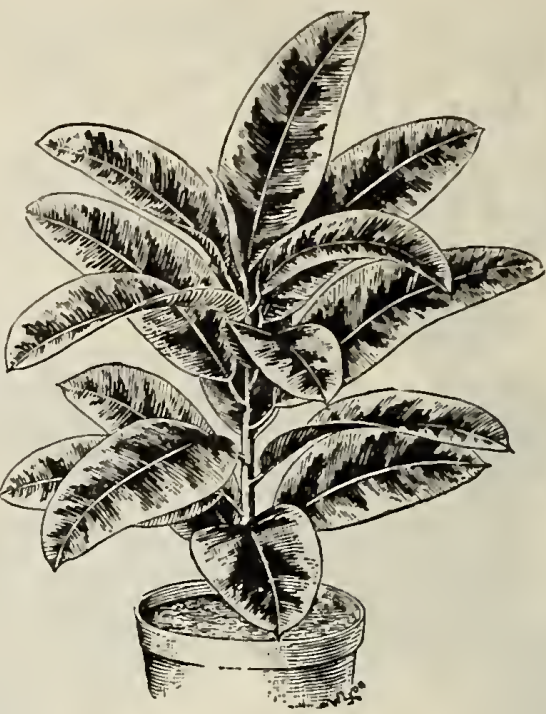

Ficus Elastica Variegata

\section{Ficus Elastica} INDIA RUBBER PLANT

Very large, smooth, leathery leaves; evergreen foliuge. The plant attains a large size and tree shape. Each new leaf is inclosed in a long coral red envelope, looking like a great red flower bud. Price, 40 cents each; large plants, 75 cents each.

We can also supply Ficus Elastica Variegata and Ficus Pandurata at $\$ 1.00$ each.

\section{Daisies}

We cannot praise too highly these pretty little spring blooming plants; charming little plants for edging and borders, among our earliest hardy spring flowering perennials. Price, 5 cents each; 50 cents per dozen.

SNOWBALL. I large and very double pure white daisy.

LONGFELLOW. Best red variety; very double.

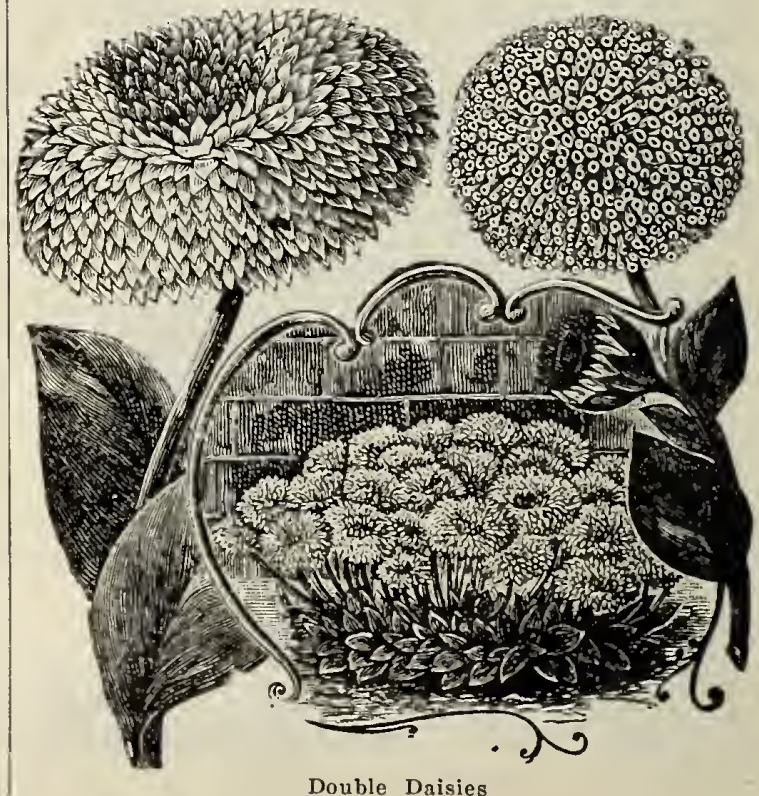




\section{LARGE FLOWERING DAHLIAS}

PRICE, POT PLANTS, 10 CENTS EACH; \$1.00 PER DOZEN.

The large flowering Dallia has come rapidly to the front as one of the most useful and ornamental decorative plants we have, and deservedly so, because of their ease of eulture and the splendid results produced. Indeed, we do not see why they should not be far more popular than the Cannas, as their flowers are strikingly beautiful, and pro. duced in splendid profusion at a time of year when flowers of all kinds are very scarce-in the early fall.

APPLE BLOSSOM. Beautiful pink, showing the many shades of the apple blossom; from faintest blush pink to a deep rose color.

ARABELLA. Primrose-yellow, tipped and shaded old rose and lavender; very fine.

CUBAN GIANT. Flowers of great size, measuring six inches across. Color dark glowing erimson, shaded maroon. Mag nificent.

CATHERINE DUER. Oherry-scarlet overlaid with erimson. Darker at the cen. ter. Its irridescence is unique and very striking, winning much favor as a cut flower variety. The fashionable flower at Newport. Especially good under arti ficial light.

CLTFFORD W. BRUTON. Immense size; color a clear, rich, canary-yellow Fine for cutting. Should be in every collection.

COUNTESS OF PEMBROKE. rosy-lake; very charming.

COUNTESS OF LONSDALE.

liar but pleasing liar but pleasing blending of salmon pink and amber, a color difficult to describe. Flowers freely under all conditions.

EVA. Purest snow-white, with $\operatorname{good}$ stems. Said by some to be the finest white variety yet raised.

FRANK SMITH. One of the best fancy Dahlias. Rich purplish maroon tipped with pinkish white, the two colors blending handsomely.

FLORENCE M. STEDWICH. Cactus. pure white, fine flowers, slightly in curved petals.

GLORIOSA. The color is the richest that can be had in any flower-bright. velvety crimson. The plant grows to velvety crimson. The plant grows to a medium size, prod
long stiff stems.

HENRY PATRICK. A pure waxy white. It blooms very freely, producin flowers from five to seven inches in diameter, with beautiful pointed petals. The plant grows to a height of five feet.

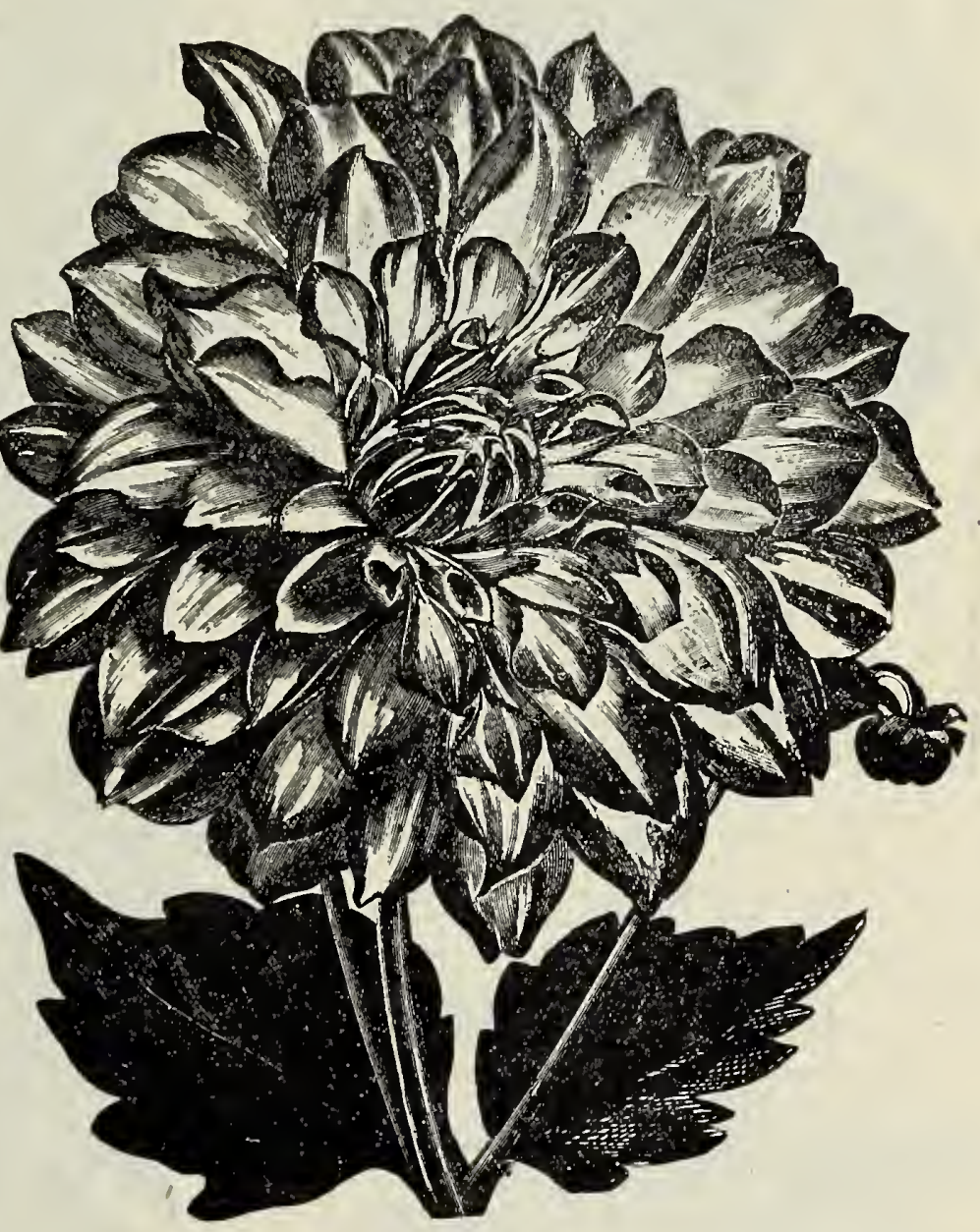

J. H. JACKSON. This is without doubt the fimest dark Cactus Dahlia. Its relvety-black crimson-maroon shade Cactus Dahlia. Its relvety-black erim

KRIEMHILDE. An exquisite, delicate shell pink shad ing to cream in the center; undoubtedly the finest and most perfect pink Cactus Dahlia to date.

MATCHLESS. Deep crimson, of large size; an early and late bloomer. This we consider one of the best ten Dahlias. Very showy in the garden.

NYMPHAEA. Most delicately beautiful Dahlia ever introduced closely resembling a pink Water Lily. Light pink tinted lighter toward center.

PERIE DE ORR. Pure glistening white of very large and exquisite form, with petals very prettily notched. Fine for cutting.

QUEEN VICTORIA. Pure canary yellow. One of the freest bloomers. Good for cutting.

RED HUZZAR. A fine ball-shaped flower. Color fiery cardinal. Rich.

ROBERT BROOMFIELD. Pure snow-white. Of large size. A very free bloomer. Frand for cut flowers. We recommend this variety.

STANDARD BEARER. A bright scarlet, clear and in-

STRAHLEN KRONE. Intense cardinal-red rich and glowing; long, twisted petals; profuse bloomer.

STORM KING. A grand, snow white Dahlia, blooms early and constantly, long stems; fine for cut flowers.

SYLVIA. Flowers of fine form and full to the center, which is white shading to a soft pink on the rim. Petals of great substance. The plant is a strong healthy grower, and bushy. An early and profuse bloomer. The fine shapely flowers are set on very long stems.

SALMON QUEEN, Beautiful, soft, lustrous pink. Grand flowers. A fine variety for cut flowers.

TWENTIETH CENTURY. Dwarf growing and bushy, with long stemmed single flowers of grest beauty. Ground color white, with a collar of varying size in richest crimson.

WINSOME. Pure white. Bears abundant masses of large, white flowers. Very desirable.

WHITE SWAN. One of the grandest large flowering white varieties for cut flowers.

WM. AGNEW. The color is the richest that can be had in any flower-bright, velvety crimson. The plant grows to a medium size, producing flowers freely on long stiff to a mer. STA 


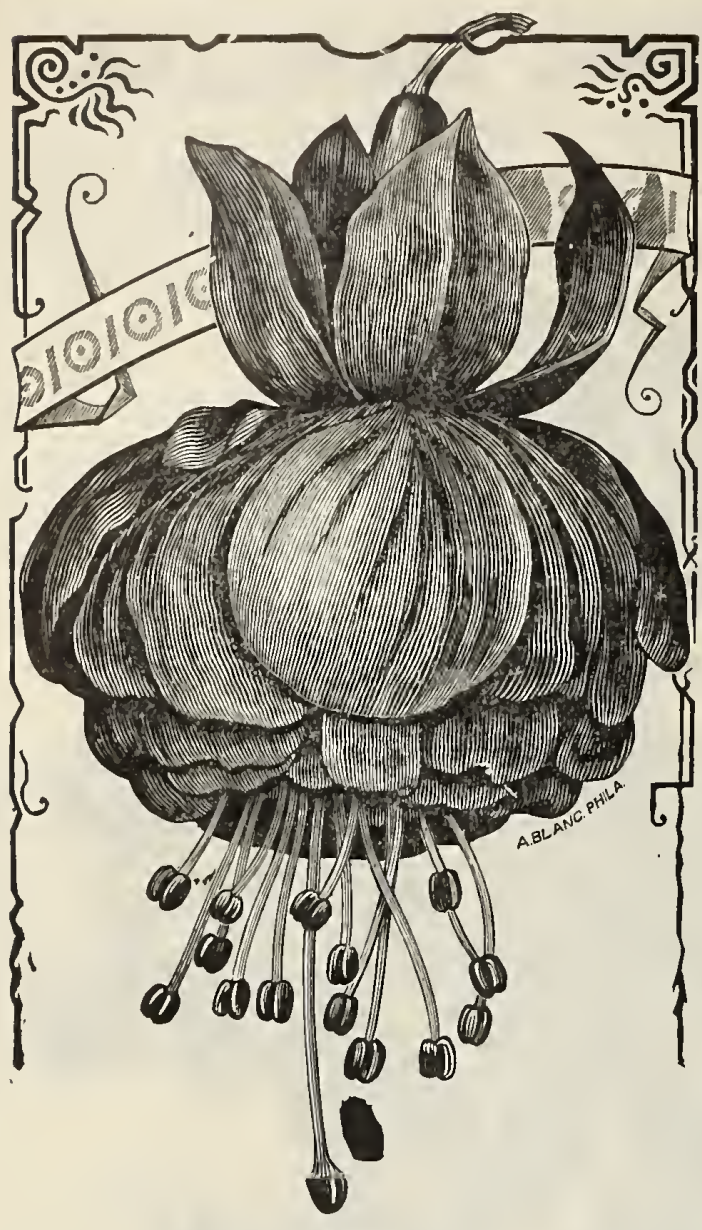

Fuchsia

\section{IMPATIENS}

BEAUTIFUL NEW EVERBLOOMING HOUSE AND BEDDING PLANTS

ALWAYS IN BLOOM. FLOWERS AS LARGE AS SILVER DOLLARS. THESE ARE GRAND NEW VARIETIES. NEVER OFFERED BEFORE.

Price, 15 cents each; any four for 50 cents.

VARIEGATA. Beautifully Striped.

ALBA RUBRA MACULATA. White with red center. ATROVIOLACEA. Deep purplish violet.

CARMINEA. Bright carmine.

DELICATA. A delicate, light rosy pink, with a dark colored center.

HOLSTII HYBRIDA AURANTIACA. Orange vermillion.

HYBRIDA ROSEA. ROsy white.

\section{FORGET-ME-NOT}

Handsome and popular flowers of exquisite sky.blue with white center on long, stiff stems. The plants con. tinue blooming from quite early until frost-or in fact. throughout the winter if potted and carried into the house. Provide a good, rich soil with plenty of moisture and some shade. Price, 10 cents each; $\$ 1.00$ per dozen.

\section{FUCHSIAS}

Price for the following Fuchsias-10 cents each; any three for 25 cents.

PHENOMENAI. Phenomenal is the largest flowered Fuchsia in cultivation. The plant is a tall grower branch. ing like a tree; the leaves are dark, glossy green, with veins of dark crimson. The flowers are of enormous size; sepals bright scarlet, with rich violet purple corrollas, very double.

BLACK PRINCE. It makes a shapely bush, is robust in growth, free from disease and insects, and is probably the freest in blooming. I have seen specimen plants six feet in height and four feet across, loaded with thousands of blossoms of a beautiful waxy carmine or pink color.

MRS. E. G. HILL. A variety unsurpassed among all the Fuchsias with white corolla. Free growing habit: strong and bushy, beginning to bloom quite early in the spring. Tube and sepals are brilliant, deep scarlet, thick and leathery in texture; corolla is very large, double, pure white.

SPECIOSA. Habit is erect and compact, presenting a decidedly neat and attractive appearance as a pot plant. The fine star shaped flowers are produced in profusion. The flowers are four inches or more in length; tube and sepels bright rose; corolla brilliant carmine.

TROPHY. This is really one of the most charm. ing and desirable Fuchsias in cultivation. Vigorous grow. ing and desiable Fuchsias in cultivation. three inches in length and of great substance. Tube and sepals are a light rosy-carmine; corolla deep carmine.

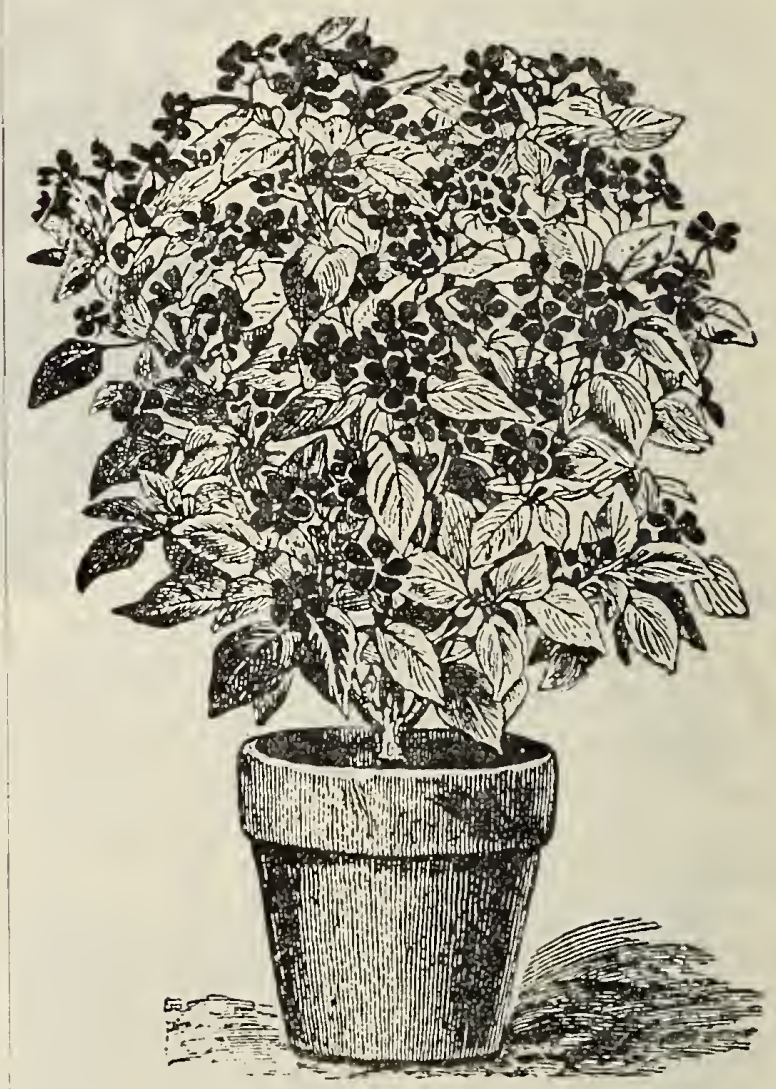

Everblooming Impatiens

\section{BEAUTIFUL WINDOW GARDEN COLLECTION}

SIX CHOICE HOUSE PLANTS F OR ONLY 75 CENTS, POSTPAID

Lovely Parlor Fern.

Elegant Palm.
1 Splendid Begonia.

1 Timerald Feather Asparagus.

SET OF SIX, POSTPATD, ONLY 7ó CENTS.
Geranium.

1 Climbing Asparagus. 


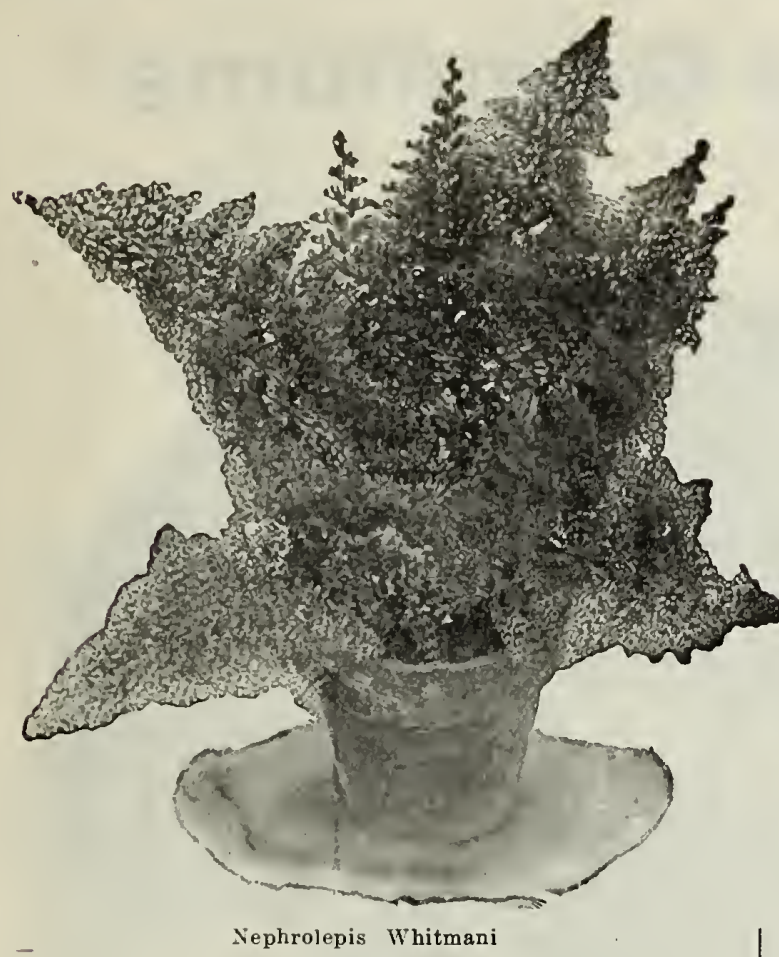

\section{NEPHROLEPIS WHITMANI}

OUR IMPROVED TYPE-MOSS CURLED

This is an aristocrat among all the Nephrolepis, and when well In this we have unquestionably the most valuable fern of the Ostrich Plume type yet introduced. Not only is it of dwarfer and more compact habit than the Elegantissima. but the leaves being more deeply divided, gives the plant a much more graceful appearance, while another important point in its favor is the fact that not a single frond has ever reverted to the common Boston Fern. We offer strong young plants, 15 cents each; four for 50 cents. Strong handsome four inch pot plants, 35 cents each.

\section{NEPHROLEPIS SCOTTII}

It is in essence condensed form of the Boston Fern with valuable characteristics added which are not evident in the parent, an average plant in an eight-inch pot having 200 fronds. It has crispness and hardiness gbout it which is superior to the parent, and because of the fact that its character is established in the smallest size, it should find ready sale at all grades. Price, nice young plants, 15 cents each; larger size, 25 and 50 cents each.

\section{NEPHROLEPIS SCHOLZELI}

\section{THE PLUMED SCOTT FERN}

It is a sport from Scotti, possessing the merits of that most popular variety, but with the pinnae sub-divided, giving it an airy feathery appearance. The fronds, like in Scotti, stand erect, with a graceful arch forming a plant of ideal shape, and they never break down giving the plant a ragged appearance as is so often the case with other plumed forms; furthermore, the loose, elegant arrangement of the fronds, allowing a free circulation of air through the foliage, prevents the center of even the largest specimen from becoming defective or yellow, which is one of men from becoming defective or yellow, which is one of plants, 15 cents each; larger, 25 and 50 cents each.

\section{COMPACT SWORD FERN}

(Nephrolepis Cordata Compacta.)

A fitting companion for the Boston; dwarfer and more erect in growth, a much darker sbade of green, and very gracefully arched. As $a$ house plant it is very desirable. Price, 15 cents each; larger, 30 cents each.

\section{TRAILING MOSS FERN}

(Selaginnella or Lycopodinm.)

Much used in fern dishes or grown up in four or five inch pots. Its foliage is always freslı green, very delicate and beautiful, lacelike. A bright green creeper that in a short time completely covers the pot, and will spread on to anything within reach. Price, 10 cents each.

\section{THE UPRIGHT MOSS FERN}

\author{
(Selaginella Emiliana.)
}

A new upright growing Moss with numerous feathery stems branching from the base and forming a dense tuft. Well grown plants attain a height of twelve to fifteen inches. We know of no Moss superior to it. Price, 10 cents each.

\section{THE BOSTON FERN}

For hanging baskets or single specimens in pots or baskets it is superb. We know of no other plant that withstands ill treatment better, or thrives so splendidly under good care. It does equally well in sun or shade outdoors during summer, and presents an imposing ap pearance indoors during winter. It forms an immense number of gracefu] drooping fronds varying in length from two to five feet, which arch over like plumes in every direction, and which are always of althy and beautiful green color. Price, strong plants, is cents each; larger, 30 cents each. Extra large, 50 cents each.

\section{THE CRESTED SWORD FERN}

(Nephrolepis Exaltata Cristata.)

A grand decorative plant, with the ends of the fronds and pinnae curiously divided and crested $A$ magnificent subject for a jardiniere. Price, 20 cents each.

\section{DWARF SWORD FERN}

(Nephrolepis Pectinata.)

This fern only grows to about a foot or less in height. Very pretty and desirable. Price, 20 cents each.

\section{NEPHROLEPIS DUFFI}

A tufted dwarf fern with branched fronds, growing to be a plant of about two feet high. Rare and choice. Price, 20 cents each.

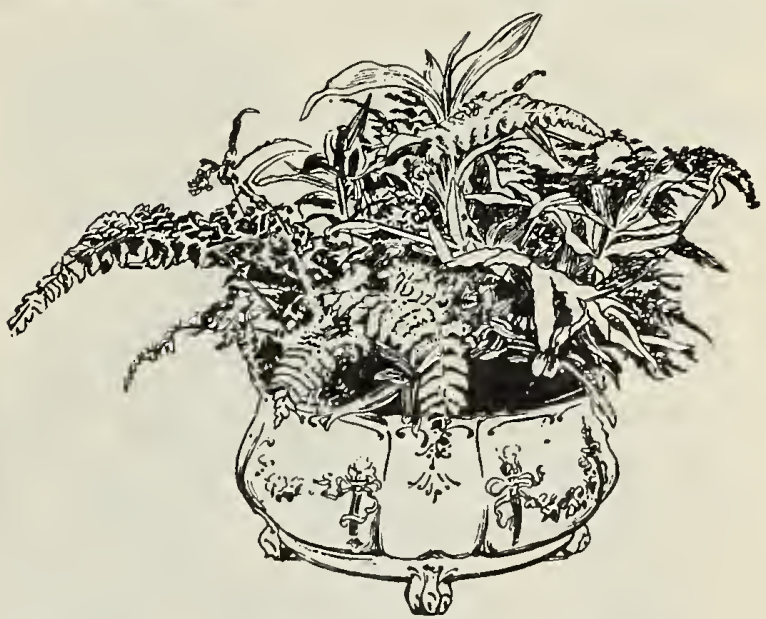

\section{SPECIAL FERN DISH COLLECTION}

COLLECTION No, $1-50$ CENTS POSTPAID

For a fern dish five to six inches in diameter, we will send you six Ferns, all different, the kinds most suitable for this purpose.

COLLECTION No. 2-75 CENTS POSTPAID

For a fern dish six to seven inches in diameter, we will send you nine Ferns, all different.

COLLECTION No. $3-\$ 1.00$ POSTPAID

For a fern dish seven to nine inches in diameter, we will send you twelve Ferns, all different. 
PRICE : Small Size, 10 Cents Each; 16 for $\$ 1.00$

A Larger SIze, 15 Cents Each; 8 for $\$ 1.00$

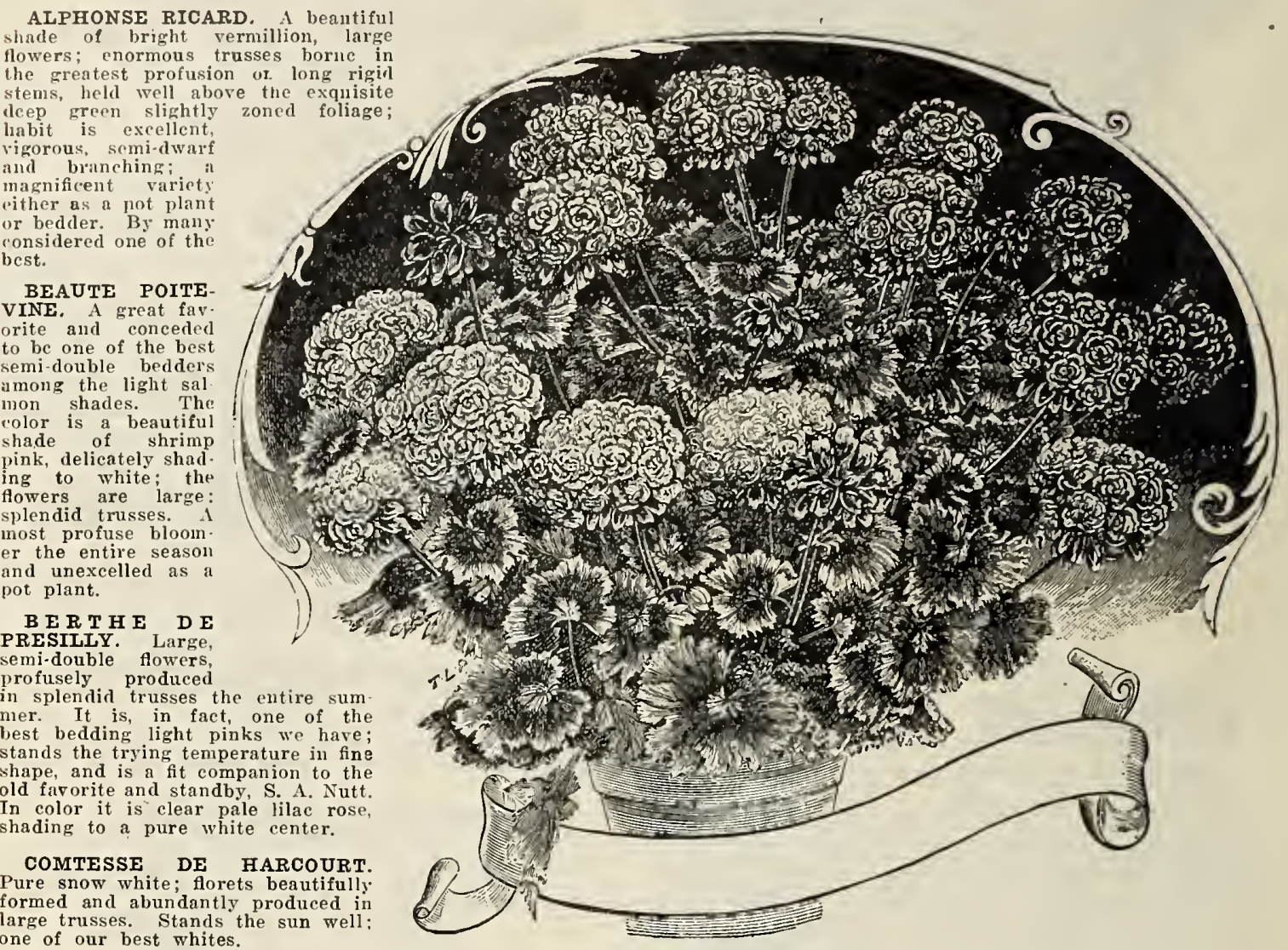

DECORATOR. Strong grower, dwarf and branching. and producing flowers in great masses. Both floret and truss are of enormous size; single or slightly double: color brilliant shade orange red.

JEAN VIAUD. The grandest pink Geranium. Of a beautiful, clear, rosy pink color, with distinct white blotch at the center. The plant itself is a vigorous grower, yet compact and shapely.

LA FAVORITE. One of the finest double whites in this class; pure in color; flowers of cnormous size; a continuous bloomer, the plant being covered with flowers the entire season; las beautiful foliage and finest habit. Unsurpassed as a white bedder.

MADAME LAPORTE BISQUIT. A very strong, vigorous, robust, semi-dwarf and compact grower. The foliage is large, handsome and deeply zoned; flowers large: trusses immense, aud freely produced; color, an exquisite shade of rich, light salmon rose, sliading lighter to an almost white margin at the edge of petals. A variety which we are confident will win a place in popular favor.
MME. LANDRY. A distinct salmon pink with a slight searlet shading, enormous trusses, and florets borne on long stems; semi-dwarf and vigorous habit. With its noble, upright nature, it is capable of standing the ex. treme heat.

MME. BUCHNER. Snow white; strong, vigorous grower, with broad fluted foliage, slightly zoned; flowers abundantly produced in large trusses.

S. A. NUTT. This is the standard dark red Geranium, more generally used than any other, both as a pot plant and for bedding. Brilliant deep scarlet, with maroon ceptionally large, strong, healthy stock of this sort.

THOMAS MEEHAN. A very notewortlyy variety. Color, distinct cochineal carmine, shaded lighter at the base of upper petals: very large flower and extremely large trusses; dwarf, compact, vigorous grower and abundant bloomer.

\section{Our Popular Bedding Collection OF DOUBLE AND SINGLE GERANIUMS}

This is probably the most popular collection we offer. Many wish to procure Geraniums for a bed in the yard and do not care for named varieties, but want just as many bediling varieties as they can get for the money. To all such we would recommend this collection. It will contain such rarietics as are most suitable for bedding. Unless ordered otherwise, cach collection will contain all different varieties, about half each of double and single varieties, but they will not be labelcd. Order early and pot them so that yon will have good, strong, well established plants by the time the ground is in condition for bedding out, all you will be rewarded hy an abundance of flowers throughout the season. Remenber, these are not rooted cuttings, but are all strong, well established plants, that have been grown in pots. 


\section{Four Fine Single Geraniums}

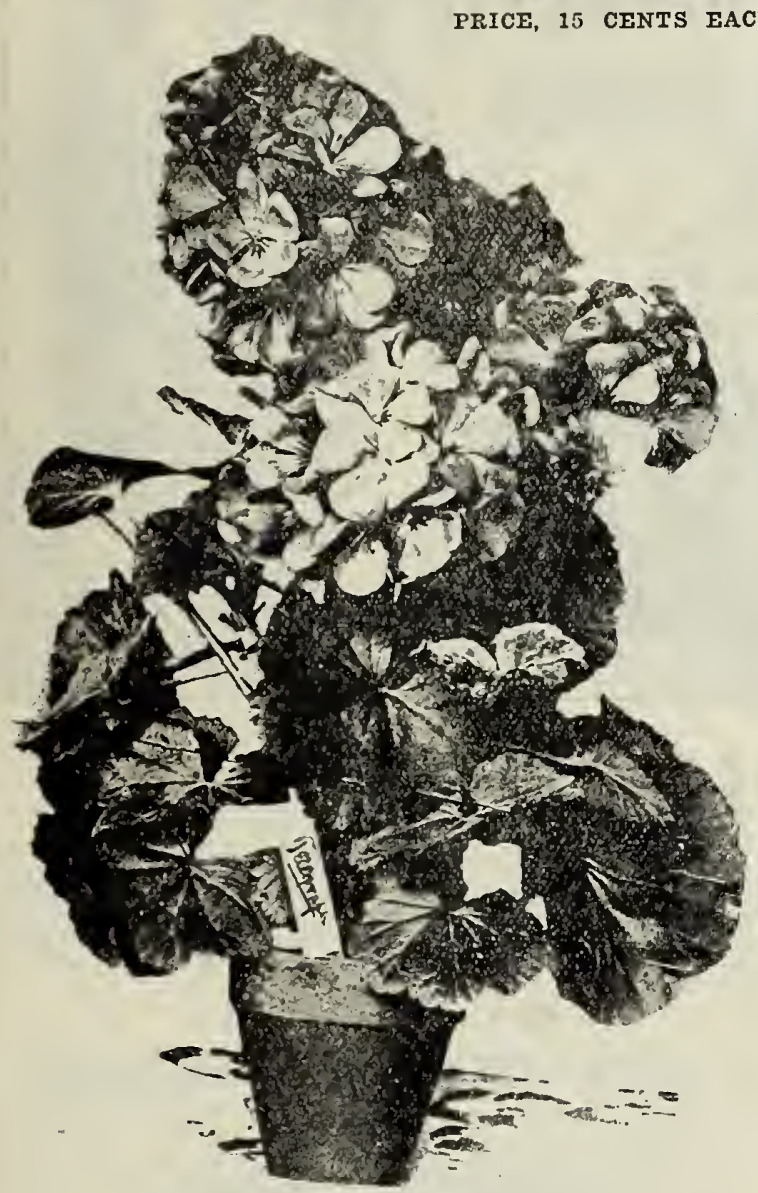

DAGATA. The flnest bodder extant; the freest grower among free-flowering sorts that we have ever met; habit perfect; freedom, wonderful; attracts attention among a hundred other sorts. 'The color is bright pure pink with large plume of white at base of upper petals; a most effective bedder, often throwing the sixth and seventh petal.

GRANVILLE. One of the finest of all the single pinks for bedding or pot culture. The plant is a prolific bloomer, and of strong, robust habit of growth. The flowers are held higli above the foliage by good, long stems, forming a mass of soft, clear pink.

L'AUBE. Pure snow wlite, retaining its purity the entire season. large round florets. magnificent trusses. Its freedom of bloom, excellent habit of clad constitution make it a most satisfactory variety cither as a bedder or a pot plant. One of the best single whites.

MRS. E. G. HILL. A magnificent variety; enormous trusses of large florets; the center of each petal is a soft licht salmon bordered with rosy salmon; habit exceptionally strong and vigorous; attractively zoned; semi-dwarf: stands the sun perfectly. An old lavorite bedder and pot variety.

\section{APPLE SCENTED GERANIUMS}

There are few, indeed, who are not acquainted with this grand old favorite. A plant of it will fill a room with its delicious apple fragrance. Price, 20 cents each.

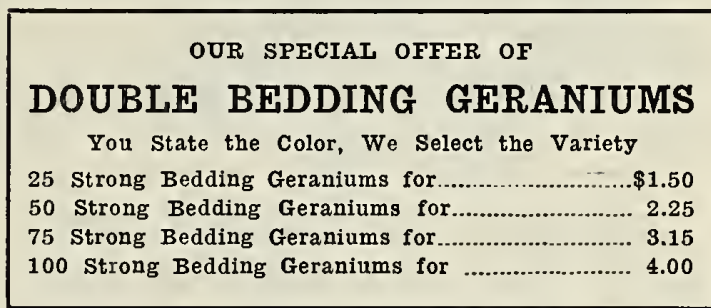

\section{IVY LEAFED GERAMIUMS}

Price, 10 cents each, except where noted.

INCOMPARABLE. Trusses are very large, florets immense and very regular form; full color; an exquisite shade of rosy carmine. Perhaps the finest Ivy to datc.

JOAN OF ARC. New Double White Ivy Geranium. The flowers are perfectly double, white as snow, and cover the plant when in full bloom.

FLOURENS. Flowers very large and double; petals large; salmon, heavily shaded rose.

LA ROSIERE. Flowers of perfect shape, double and of good size; rich, glistening rose color.

MRS. HAWLEY. This fine new Ivy Geranium is a much improved Souv. de Chas. Turner, with more vigorous habit. The flowers are large in fine trusses on long stcms. Price, 15 cents each.

\section{VARIEGATED LEAF GERANIUMS}

Price, 15 cents each; two for 25 cents.

MADAME SALLEROI. It makes a round, pretty plant. about one foot high and wide; foliage bright green, edged with pure white.

MARSHAL MCMAHON. Large, handsome, golden ycllow leaves, broad, dark, bronzy red zone.

SILVER-LEAVED S. A. NUTT. Green, edge white; very similar to Ime Salleroi: much stronger grower: flowers large, produced in fine trusses; very free bloomer; flowers large, produced in fine
collor brilliant crimson scarlet.

MOUNTAIN OF SNOW. A fine, strong grower; center of leaf bright green, with a broad silvery white margin; flowers a scarlet, well above the foliage.

MASTERPIECE. Golden yellow foliage, with broad very dark zone, variegated rich blotches.

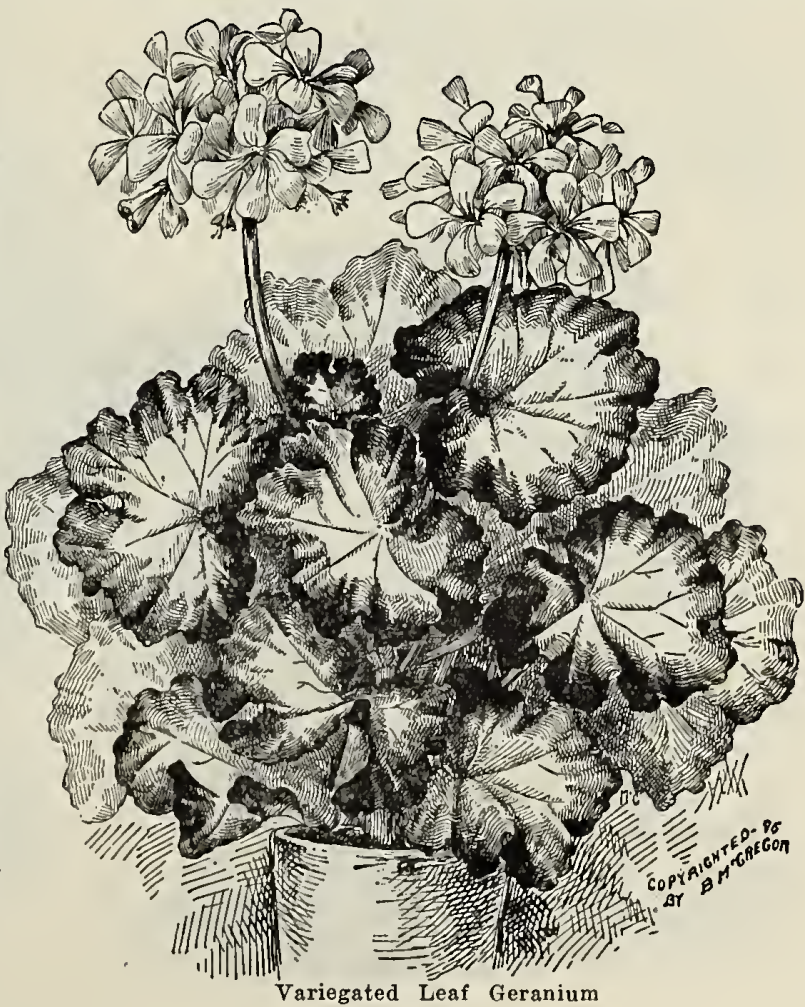




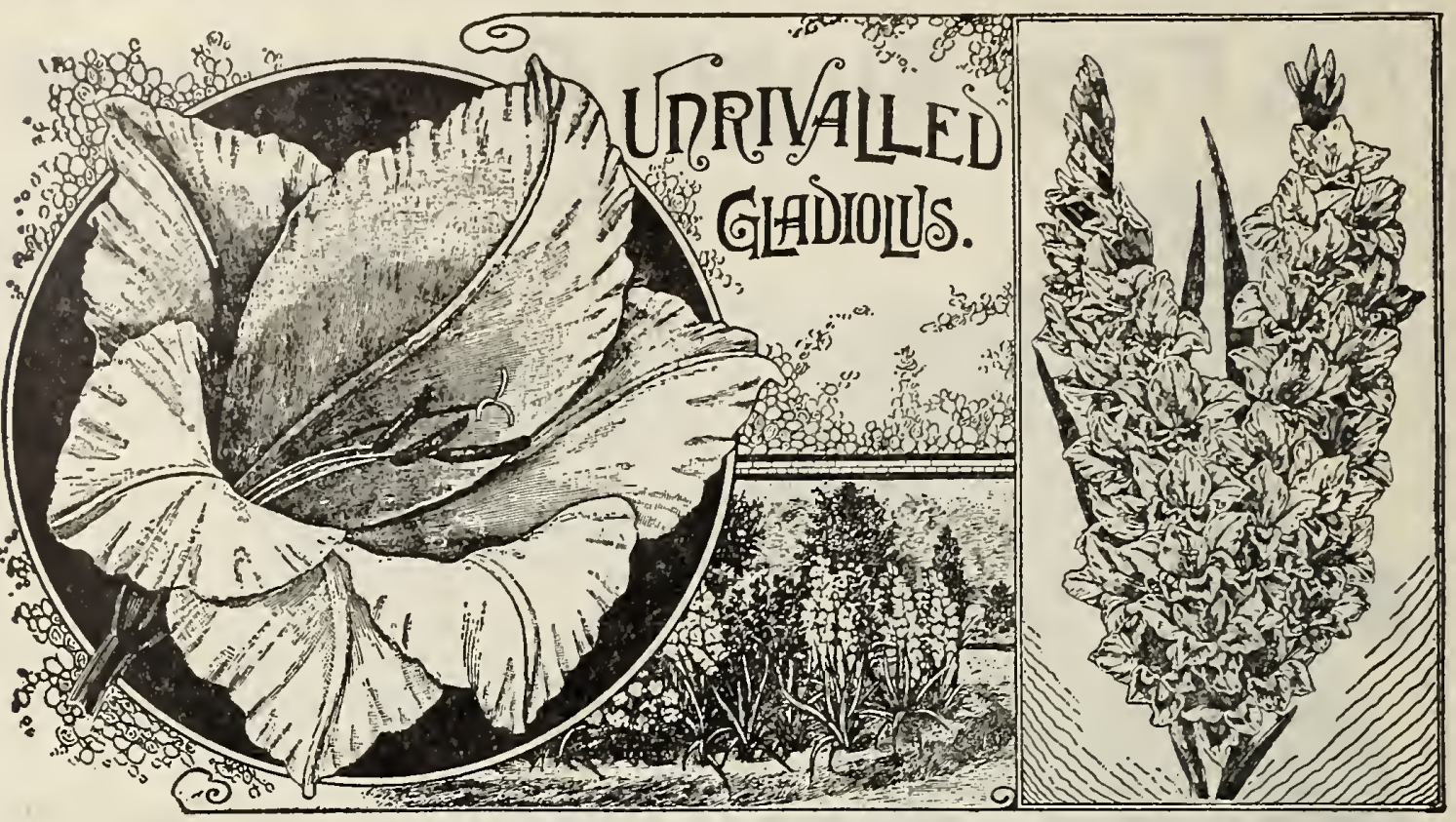

\section{GLADIOLUS}

NOTE.-This illustration shows a single spike and part of a bed of our large floyering Gladiolus as they appear when in bloom. Our splendid Gladiolus are among the brightest and bandsomest of all summer fiowering bulbs. They cost but little, are no trouble to grow, and are absolutely sure to bloom. Tbey do well everywhere. The bulbs will keep dry till wanted, and by planting at different times you can have a succession of grand flowers from June till October. When killed down by frost, lift tbe roots, eut off the tops and store in cellar; they will keep perfectly till time to plant again next season. Remember, we send choice selected bulbs only, sucb as are sure to produce large flowers of greatest beauty. Price, all colors mixed, sis for 25 cents; 40 cents per dozen; forty for $\$ 1.00$.

\section{GERMAN OR PARLOR IVY}

A strong growing climber, suitable for large baskets or vases, well adapted for covering trellis work quickly or trailing in the parlor. Leaves glossy green and flowers yellow in clusters. Price, 10 cents each.

\section{GYNURA AURANTIACA VELVET PLANT}

Telvet Plant seems an appropriate name, the leaves being always taken as artificial. Tbey and the stems are entirely covered witb purple hairs: sbining. glistening, reflecting many new colors. Any change of position appears to alter the color of the foliage. Price, 10 cents

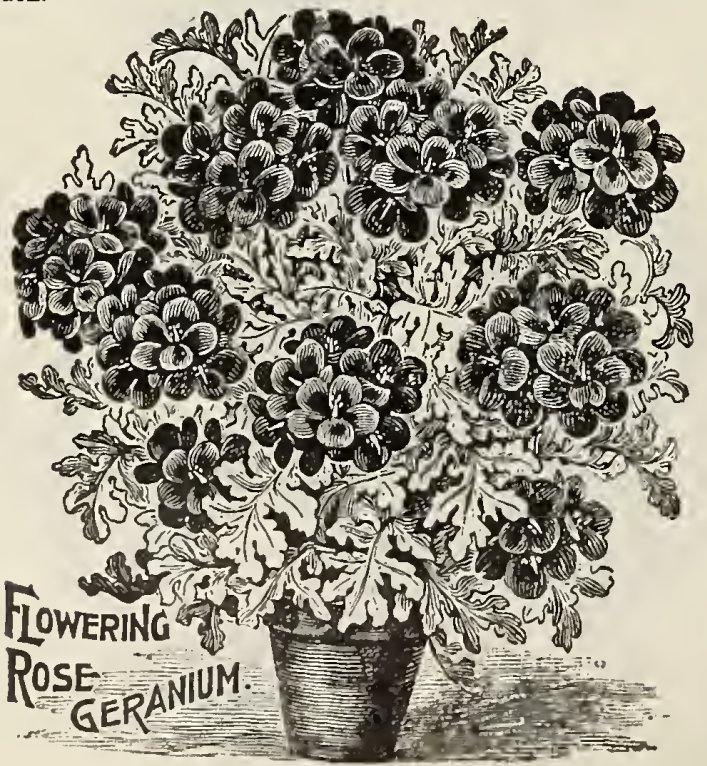

\section{NEW IMPERIAL GLOXINIAS}

Words cannot describe the rare beauty of these flowers to one who has never seen them. The flowers often measure three inches in length and two in width, and are npright and pendulous. They succeed well with ordingry care and should be grown in a moderately shady plscen. as the sun burns the foliage when wet, causing brown spots to appear. Plant bulbs in a mixture of light loam, manure and sand, equal parts, giving but little water. until signs of life appear. You will hare a succession of bloom from June to September. When done bloominz dry gradually, and keep in pots orer winter in a warm place.

GRAND SPECIAI OFFER. 15 cents each; four for 50 cents.

\section{GERANIUMS}

WITH FRAGRANT FOLIAGE

Price, 10 cents each; three for 25 cents, except where noted.

The fragrant Geraniums are a treasure. Tbeir leares are beautiful, as well as fragrant. Some are more finely cut and rariegated, as will be seen in the descriptions buttonhole flowers, they are indispensable.

DR. LIVINGSTON. A skeleton leaved, rose scented, with finely cut foliage.

MRS TAYLOR. A distinet rariety of the scented Geranium, with a strong rose fragrance and large, deep scarlet flowers.

MRS. KINGSBURY. Fuchsia red, shading lighter to white eye; upper petals veined maroon; large flowering.

TRANSIT. An elegant new variety of the Rose Geranium, with gracefully cut foliage.

LEMON.

NUTMEG SCENTED.

BALM SCENTED

ROSE SCENTED 
3OS.W.VESTAL \& SON

\section{tour}

PRICE, 15 CENTS EACH; FOUR SORTS FOR 50 CENTS.

Heliotropes are universal favorites on account of their delightful fragrance and fowering equally as well as bed. ding plants in the Sum ding plants in the summer, or as pot plants in the house during tbe Winter. A bed filled witb them produces a mass of color that can hardly be equalled by any other
kind of plants. Indeed, there is nothing tbat will give so many sweet-scented flowers all through the Summer as Heliotropes, They can be potted up in the Fall and will flower more or less all Winter.

ALBATROSS. Elegant dwarf bushy growing, new var iety of great merit, large panicles of pure white flowers in great profusion all season; the best white variety to date.

HEAVENLY BLUE. Large, close panicles of exquisitc light blue flowers, witb white eve Grows vigorously and fowers abundantly very fiue for bedding out for and fowers abundantly: very fille for bed

LAVENDER QUEEN. Enormous florets, very large trusses of bloom; color, a beautiful shade of lavender, suffused with rosy mauve. A dwarf, robust grower and very free and continuous bloomer.

ROYAL PURPIE. Very large and fragrant, color deep violet purple, witb white eye, very floriferous, and cannot be too bighly recommended for bedding out, for which pur. pose we offer it at $\$ 1.00$ per dozen.

\section{GOLDEN GLOW}

\section{RUDBECKIA LACINIATA, FL. PL.}

A hardy perennial plant growing eight feet bigh, branching freely and bearing by the hundreds, on long, graceful stems, exquisite double blossoms of the brigbtest golden color, and as large as Cactus Dablias. Mr. Wm. Falconer says of it: "When I saw tbe double flowering form of Rudbeckia Laciniata in bloom last year I was amazed, for notwithstanding my long and intimate acquaintance with plants, I bad never before seen a double flowered Rudbeckia." Price, 15 cents each.

\section{HOLLYHOCKS}

Extra large flowers; petals finely curled and fringed; colors shell-pink, rose and ruby-red. Entirely different from all other Hollyhocks. Price, 15 cents each; eight for $\$ 1.00$

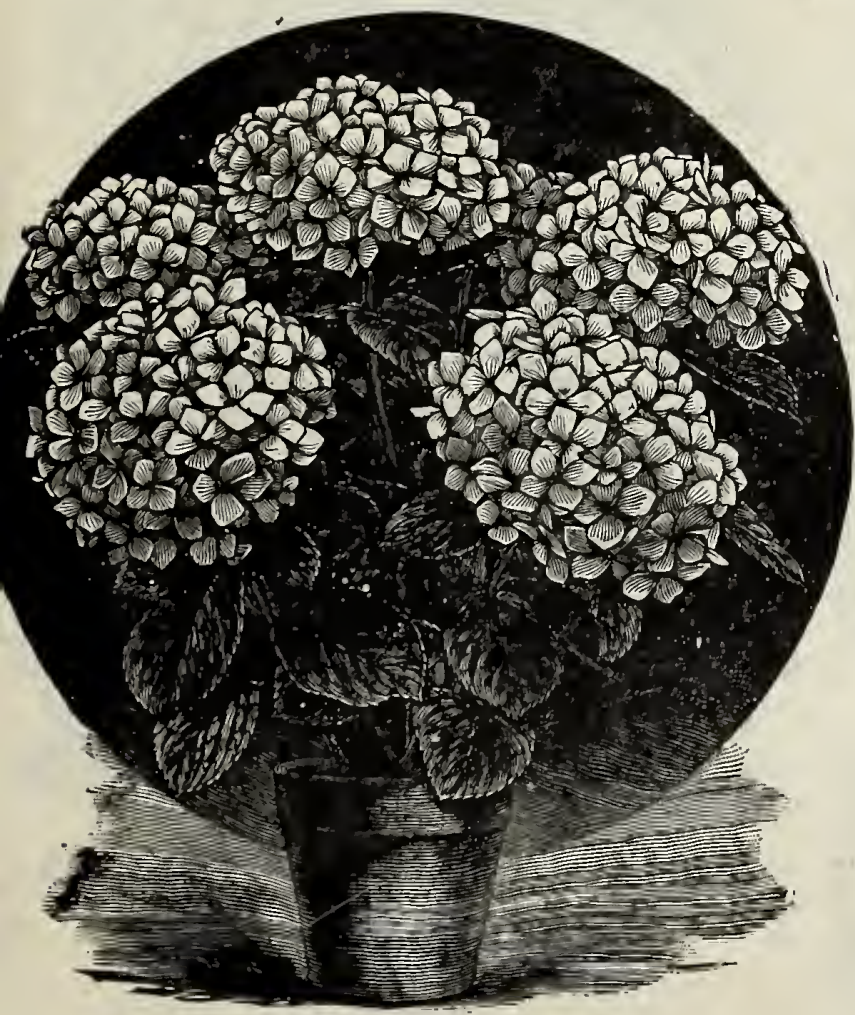

GAILLARDIA GRANDIFLORA

\section{(BLANKET FLOWER.)}

Makes one of the most gorgeous and prodigal displays of all perennials. Flowers often measure tbree inches in diameter, on clean two feet stems. A hard center of deep maroon is thickly bordered by petals of orange and yellow, strikingly ringed by circles of crimson, red and maroon. Poor soil will do, and a constant show is assured from June till frost. Price, 10 cents each; $\$ 1.00$ per dozen.

\section{HYDRANGEAS}

Did you ever see a well grown specimen of Hydran gea growing in a tub on the porch? Do you know of any plant easier grown that is more showy and attrac tive? The old ITortensis is the variety generally grown

HORTENSIS. A well known favorite old plant, pro ducing large heads of pink flowers in great profusion. It thrives best in a shaded situation, with a plentiful supply of water. Price, small plants, 10 cents each: large, 25 cents, 50 cents, $\$ 1.00$ and $\$ 2.00$.

THOMAS HOGG. This is the finest of all Hydrangeas. The flowers are produced in immense trusses of the purest white, of very fine texture, and continue in fower for a great length of time. Quite hardy in open ground. Price, small plants, 10 cents each; large plants, 25 cents each.

RED BRANCHED. A valuable Hydrangea, with dark red branches that brighten to a clear crimson color as they ncar the flower trusses. The plant is of robust habit, and produces freely immense heads of deep rose colored flowers. A novelty of sterling merit that is sure to become very popular. This is by all odds the prettiest Hydrangea. Price, small plants, 25 cents each.

JEANNE D'ARC. A new variety of exceptionally gond merits, It is a variation of the old favorite Thomas Hog, but having the dark reddisl-brown stem of Ramus Pictis. The plant is more vigorous in growth than eitler, and the foliage and flower much larger. The flower is pure white and very effective against the dark green foliage. Price, 15 cents each; large, 30 cents each. 


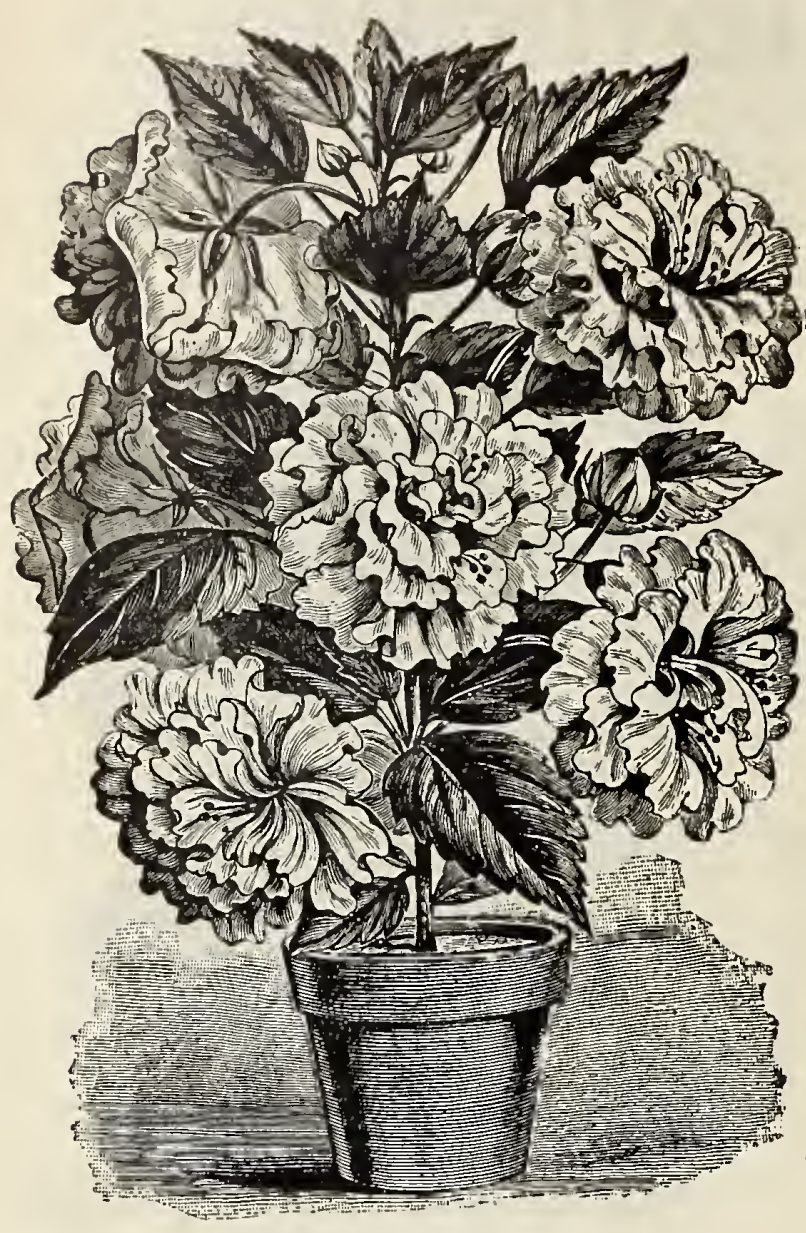

Peachblow

\section{WONDER LEMON}

THE LARGEST AND FINEST EDIBLE LEMON IN THE WORLD.

May be used anywhere that ordinary Lemons may be used, and one of these is equal to eight or ten common Lemons. Has very thin rind for such large fruit, and its acidity is unsurpassed. Highly recommended for lemonade and all culinary purposes. The dark green foliage is very large and handsome, and the waxy white flowers, with yellow stamens, are nearly as large as Tuberose blossoms and as fragrant as Orange blossoms. We guar. antee every tree to produce the same large fruit. No bud. ding or grafting necessary. It is of the easiest culture, flowering and fruiting in any good ordinary soil. Price, for very strong young plants from $2 \frac{1}{2}$ and 3 inch pots, 15 cents each. Strong handsome plants from 4 inch pots, 15 cents each. Strong handsome plants from 4 inch pots, 25 cents each. Large two year old plants, fruiting size, 8 inch pots, exceptionally fine fruiting size, $\$ 1.00$ each.

\section{OTAHEITE ORANGE}

A grand pot plant of great beauty and novelty. It is a dwarf orange, which grows, blooms and fruits freely in pots, even when only a foot or two high. The fruit is about one-half the size of ordinary oranges, and very sweet and delicious. The blossoms are produced in great abundance, delicate and beautiful in color, and rich in delicious pefume. As a pot plant this lovely dwarf orange is one of the most novel and beautiful that can be grown. It blooms most freely during winter, though it is likely to bloom at nny and all times a year. Price, young plants from 3 inch pots, 15 cents each. Plants from 4 inch pots, 25 cents each. Fruiting size, $\$ 1.00$ each.

\section{HIBISCUS \\ CHINESE}

Large growing tropical shrubs, with large glossy, dark green foliage, blooming freely in our hottest sun, pro ducing their enormous bright colored flowers in great numbers during the entire summer. Succeeds admirably bedded out during the summer, producing a very tropical effect, the blooms averaging five or six inches in diameter and are gorgeously colored. The plants can be wintered over in a warm cellar or pit, and again bedded out in summer. We have reduced the price, bringing them within reach of all. Price, first size, 10 cents; second size, 20 cents.

AURIANTICA. Large, double, orange colored flowers; an early and profuse bloomer.

BRILLIANTISSIMA. The largest flowered of all the single varieties. Color a brilliant crimson scarlct, flushed with orange, the base of petal stained deep crimson; an extra fine variety.

COLLERII. Double; yellow, with maroon center; very fine; free flowering; best of this color.

GRANDIFLORA. Rich, glossy foliage, blooming pro. fusely throughout the summer, literally covering the plant with scarlet crimson flowers.

LAMBERTII. Flowers large, of deep crimson color; very fine.

SINGLE ROSE. Of a rose color.

SUB VIOLOCEA. Flowers enormous, semi-double; clear carmine tinted with violet. Probably the largest fiower in the Hibiscus Chinensis family. An unusual free bloomer.

\section{Peachblow}

\section{NEW PINK HIBISCUS}

This Hibiscus is a sport from the double red Hibiscus Rosea Sinensis; the flowers are double and from four to five inches in diameter; of a charming, rich, clear pink color. Price, 10 cents each; larger size, 20 cents each.

\section{NEW DOUBLF Blue Lobelia}

KATHLEEN MALLARD. This beautiful and distinct Lobelia is a variety of $L$. Speciosa which originated from a chance seedling. The color is the most beautiful and intense blue; the flowers reach three-fourths inch in diameter and literally cover the plant. Price, 15 cents each; $\$ 1.25$ per dozen.

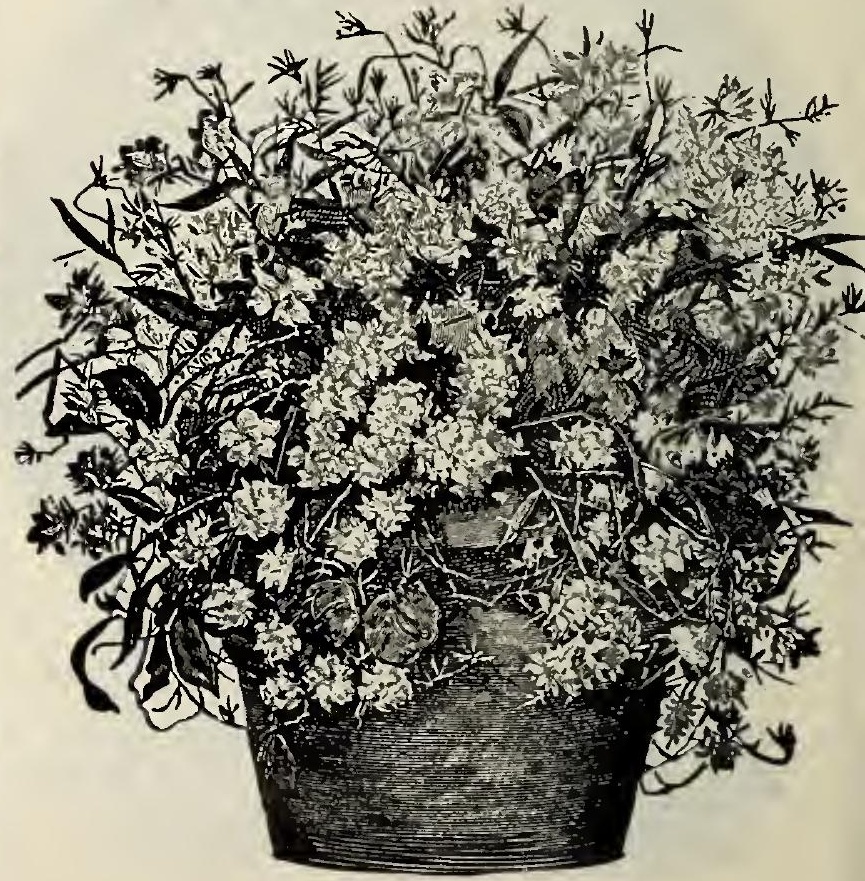




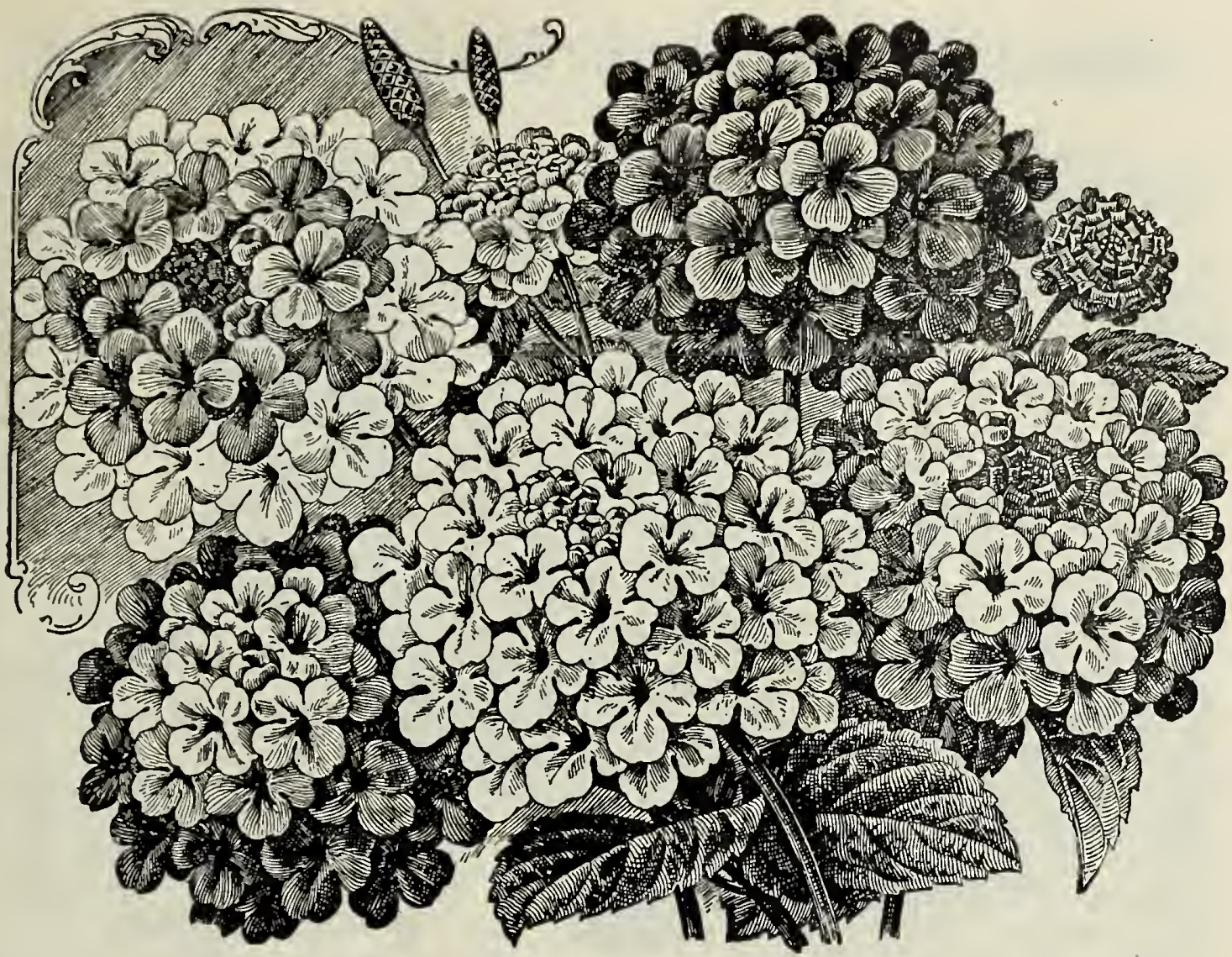

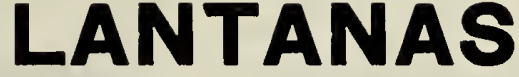

Try a few Lantanas this year for bedding. They stand sun and drouth remarkably well, and are never out of bloom. Grown in pots or tubs, they make splendid specimen plants for porch or lawn, and can be kept in a light cellar during the winter. Price, 10 cents each; three for 25 cents.

A COOK. Dwarf; opens orange and yellow; chenges to bright rose; a free bloomer; foliage and florets small; very pretty.

ALBA PERFECTA. Pure white. A gem among white bedders.

FRANCINE. Quite dwarf; flowers large; rosy lilac.

FARFADET. Golden yellow florets at the center; next of orange with orange red at the circumference.

JAVOTTE. Center bright yellow; light border; very free bloomer; a good variety.

JACQUES MINOT. Plant vigorous but compact in growth: flower at first opening is deep orange red, chang ing to deep vivid crimson; very fine, and briglitest Lantana we have.

LEO DEX. Opens bright yellow to orange scarlet, changing to a bright crimson; dwarf.

RADIATION. Opens orange yellow, changing to brilliant red florets, very large; a good bloomer, showing both colors until in full bloom.

SUNSET. Bright golden yellow of immense size, chang ing to orange and yellow, with brilliant red center.

PINK BEAUTY. Covered with flowers of silvery rose with center of sof yellow; a beautiful contrast.

THAIS. Blush, shading to cream.

ULTIMA. Magnificent pure golden yellow.
VIOLET KING. The buds and umbals extra large, or light yellow and pink; opens yellow and golden center, and as they open changing to pink and orange. When about one-half in full bloom the first florets change to a beau. tiful violet maroon shade and show all of those colors until in full bloom.

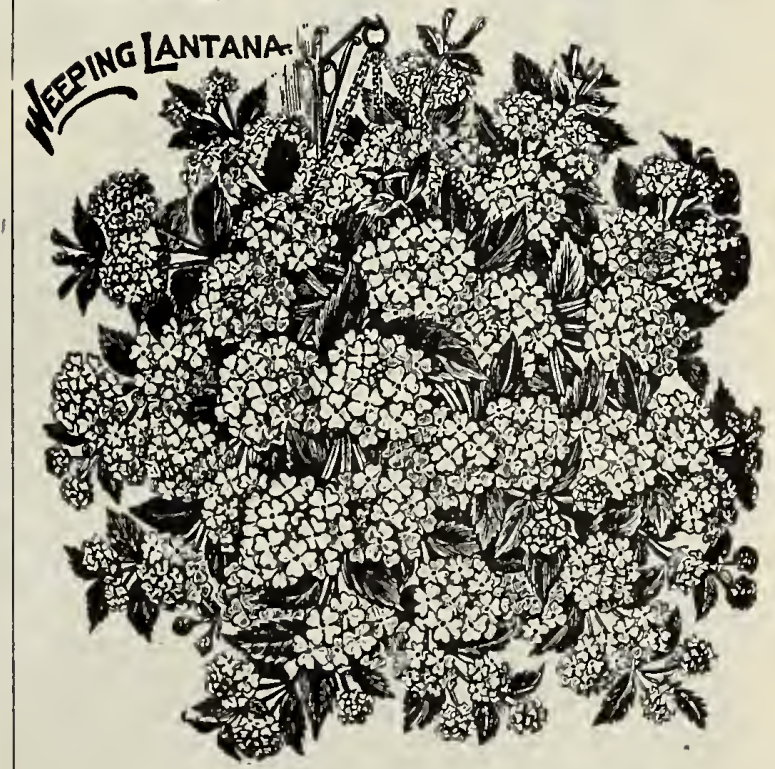

WEEPING LANTANA

This plant is of very rapid growth, and graceful droop ing habit, with lovely dark green foliage, producing a cluster of fiowers at each leaf. The flowers are a most delicate, clear, brilliant, rosy lilac color. Price, 10 cents each; three for 25 cents. 


\section{Beautiful Hardy Garden Pinks}
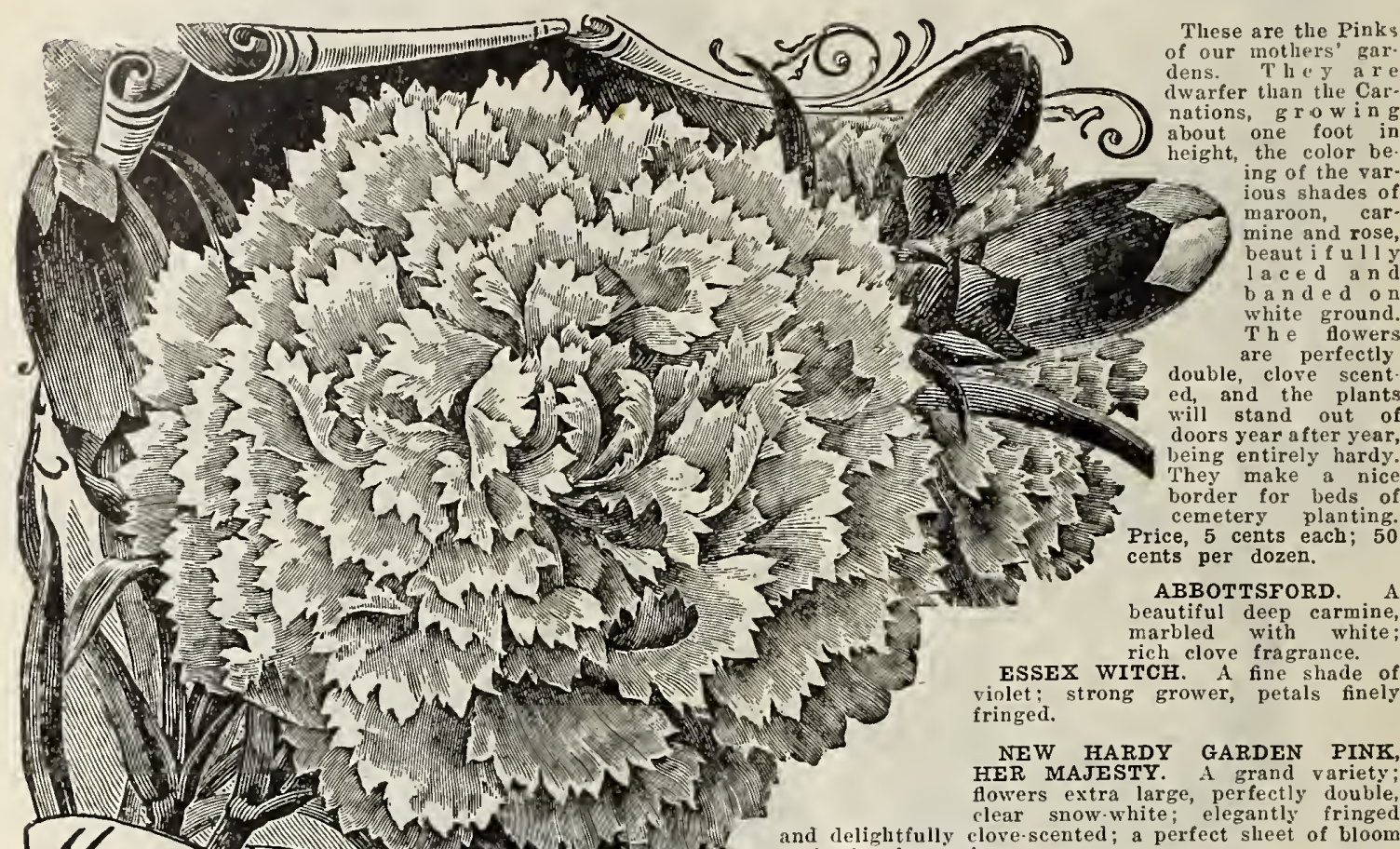

beautiful deep carmine, marbled with white; ESSEX WITCH. A fine shade of violet; strong grower, petals finely fringed.

NEW HARDY GARDEN PINK, HER MAJESTY. A grand variety;

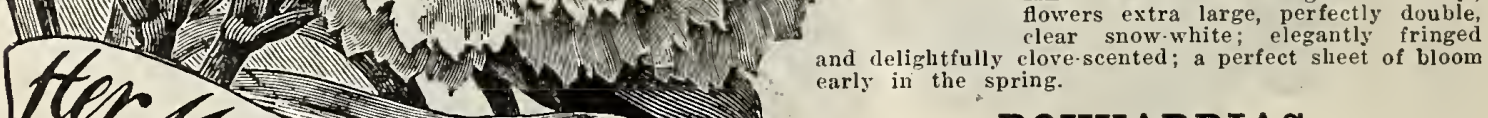

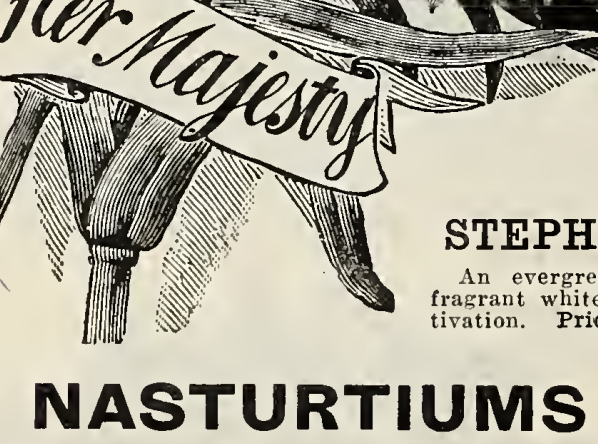

DOUBLE YELLOW. The flowers are three inches or more in diameter and are perfectly double of a bright yellow, with a rich' crimson feathered blotch at the base of each petal. Price, 15 cents each; $\$ 1.50$ per dozen.

DOUBLE CRIMSON. Similar to the above in growth: rich fiery crimson. Price, 15 cents each; $\$ 1.50$ per dozes.

\section{MANETTIA "BICOLOR"}

$A$ beautiful free growing vine, with small tubular shaped flowers of a rich, fiery scarlet color, shading off into a bright yellow at tip of flower. It commences to bloow when very small and flowers continually. A valuable
plant for small trellises, vases or baskets. Price, 10 cents each.

\section{MAGNOLIA FUSCATA}

A most desirable greenhouse slirub, succeeding admir ably as a window plant. It produces its brownish yellow fragrance, similar to a ripe banana. Price, strong plants, 40 cents each.

\section{OLEA FRAGRANS}

An old favorite greenhouse slirub, succeeding admirabl as a house plant, producing small wlite flowers which are the entire winter. Price, strong plants, 35 cents each.

\section{BOUVARDIAS}

Shrubbery plants, with corymbs of white rose, crim. sund scarlet flowers, blooming during the autumul and winter. Their dazzling richness of color makes them one of the most useful of our winter blooming plants. Price, 15 cents each.

\section{OTIS FLORIBUNDI

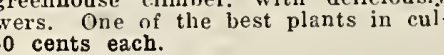

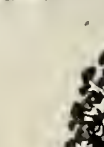
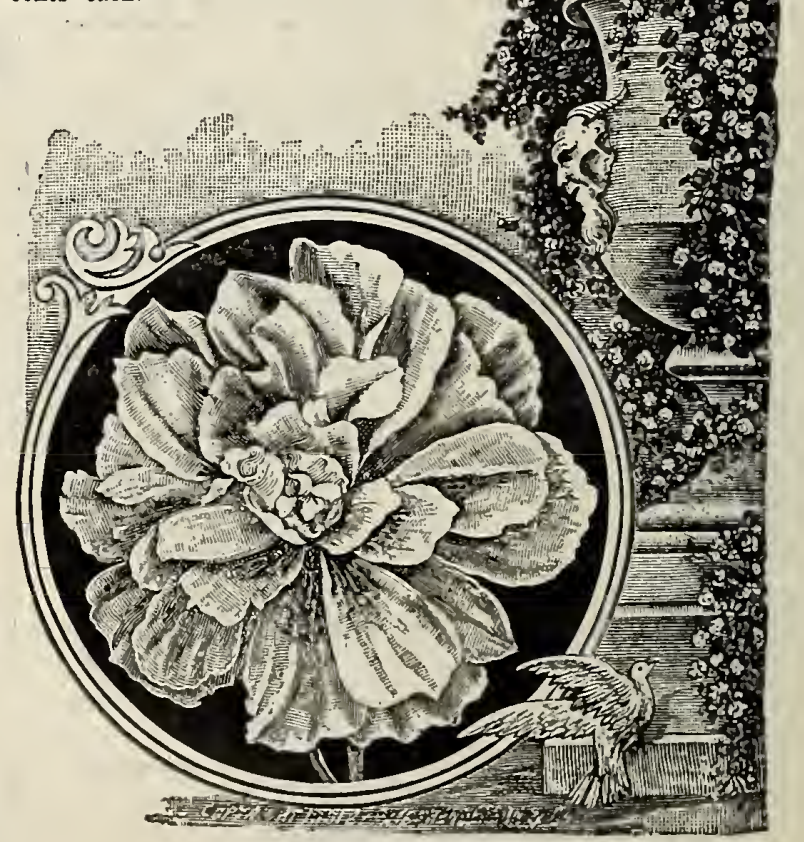


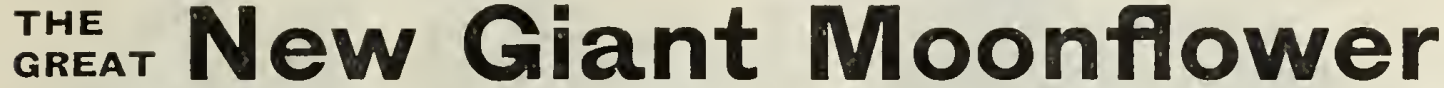

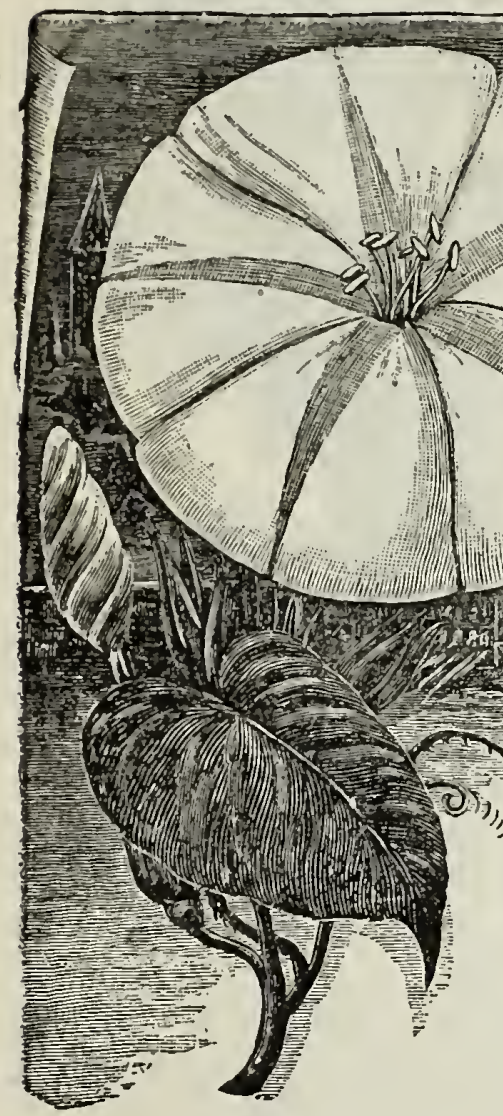

IPOMEA MAXIMA

\section{MADAGASCAR PERRIWINḰLE} OR VINCA

This is a most attractive plant, blooming the entire summer season, forming a handsome shrub two feet in height and diameter. Color, rose, white, and white with height and diameter, Color, rose, white, and white
crimson center. Price, 10 cents each; $\$ 1.00$ per dozen.

\section{MADEIRA VINE}

(Mignonette Vine.) The glossy, waxy leaves of this dainty vine from the Andes makes it, perhaps, the most liked of all climbers. The leaves are light green above and rosy chocolate underneath; flowers white and deliciously fragrant. Grows well in garden or pots, hanging baskets or vases. In fall take up the roots, if in garden, and keep warm and dry over winter. Give tubers same rare as dahlias. Price, 5 cents each; 40 cents per dozen.

\section{NIEREMBERGIA}

RIVULARIS. A charming dwarf creeping Alpine plant, bearing large creamy white, cup shaped flower's from June until Septemher; most desirable plants for the rockery and succeeds equally well in the border. Price, 15 cents each; $\$ 1.50$ per dozen.

\section{OLEANDERS}

These old fashioned shrubs are becoming immensely popular again. No plant makes more handsome specimens in tubs for the veranda or yard. Can be wintered in the cellar.

ROSEA. Has double pink flowers. The old favorite. Very sweet. Price, 15 cents each.

LILIAN HENDERSON. HIas double white flowers of the largest size. Fragrant like the old double pink. Scarce. Price, i5 cents each.
1 giant in prowtle and fiowcr's and exquisitely fragrant. We were the first to give great "Moon Flower," the name also originating with the founder of our firm. No plant within our knowledge, hrought from obscurity, has achieved more wide popularity or given more satisfaction to millions of people. It is with pleasure of people. It is with pleasure therefore that we offer

The flowers are more than twice the size of the old variety, selected flowers reaching seven and one-half inches, and are produced in such wonderful profusion that they com. pletely cover the vine with a veil of glistening white, On moonlicht nights and cloudy days the effect is charming in the extreme. It forms a perfect sereen of rich green foliage and there is nothing to equal it for porches. Add to these qualities its delightful sweet magnolia fragrance and prosaic fact or poetic fancy could not ask more. (See cut.) Prico 10 cents each. Or we will send five each of these two handsome climbers. or ten of one kind, for only 60 cents.

THE BLUE MOON FLOWER profuse bloomers and delightful ly fragrant. A handsome, quick growing, rennial climber. It often flowers in bunches of a half dozen. The flowers are frows about twenty-five feet in one season. Price, 10 cents each; three for NEW MARGUERITE MRS. F. SANDER

Unlike all other Marguerites, its color is of the purest glistening white throughout; in size it frequently measures five inches across; the center of the flower is a mass of closely arranged fringed florets; these are surrounded or edged by the broad, shining white ray petals, forming a flower which reminds one forcibly of a glorified double Pyrethrum. These are produced on long stems with a freedom not known in other varieties of the Marguerite. Price, young plants, 10 cents each.

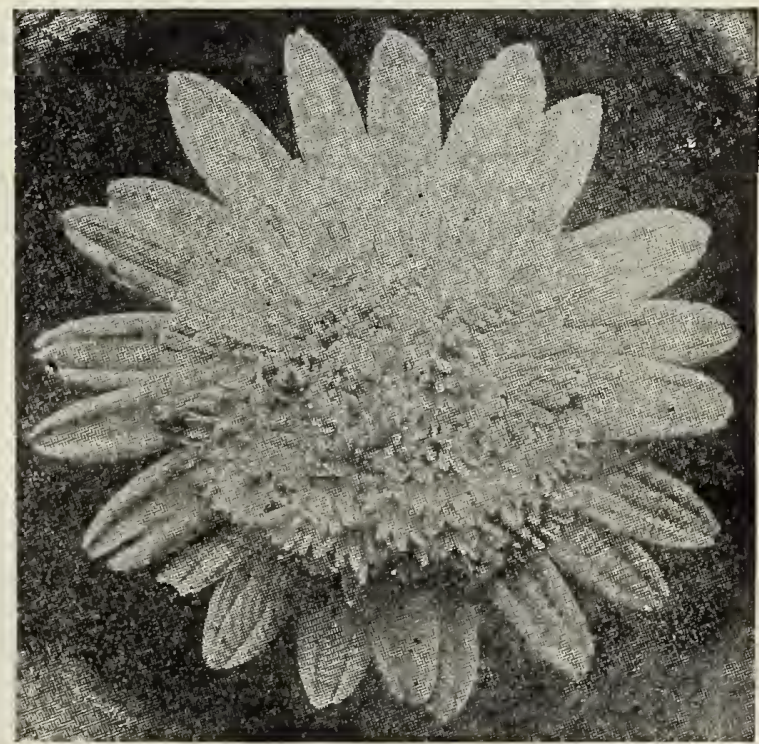




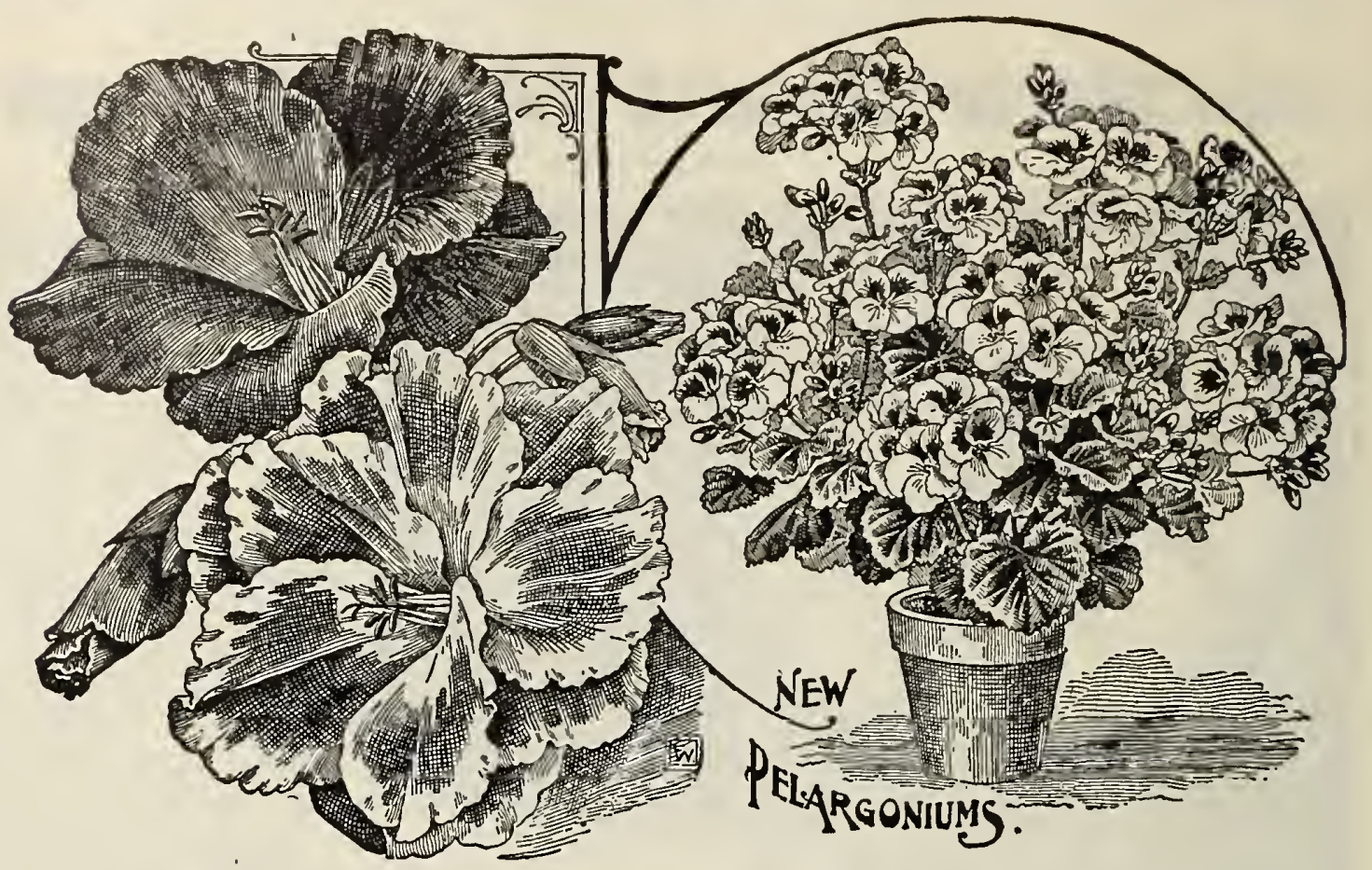

\section{Lady Washington or Pansy Geraniums}

The flowers of these Pelargoniums are bright cherry red, with white at the base of each petal; the two upper petals are dark crimson maroon. The flowers are of immense size and very freely produced. It is this combination of coloring with blotches which obtained for it the title of "Pansy Geranium." Price, 15 cents each; four distinct varieties for 50 cents.

\section{Parrot's Feather}

An aquatic hang ing plant is a novelty indeed, and we have it to perfection in this dainty little jewel. Its long, trailing stems are clothed with whorls of tho most exquisite foliage as finely cut as the leaves of the cypress vine, and much more delicate.
Planted in a water. tight hanging basket, so water can be kept standing on the sur. face, it will trail finely. Price, 10 cents each.

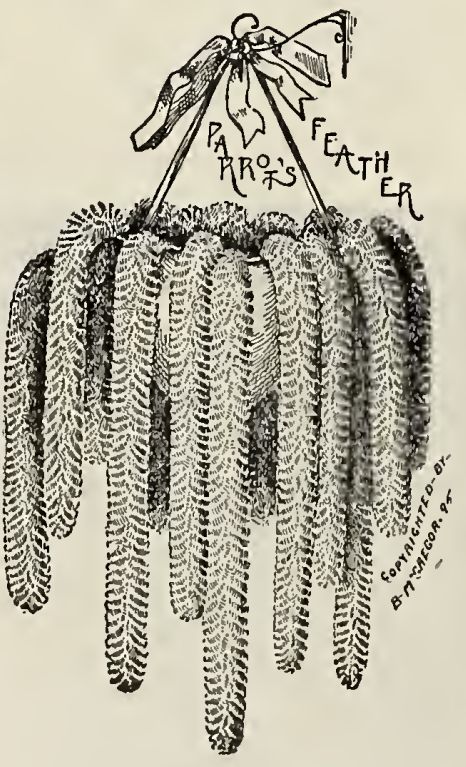

\section{POINSETTIA PULCHERRIMA}

This is the plant which produces the large clusters of red leaves or flowers which are seen in all the flower stores at Christmas. Price, plants from three inch pots, 15 cents each.

\section{PLUMBAGOS}

The Plumbagos are always satisfactory plants, either for pot culture or for the garden. They are constant bloom. ers, and their delicate and graceful ftowers are very useful for cutting.

CAPENSIS. A well known favorite. Sky blue flowers. Price, 10 cents each.

LADY LARPENT. Hardy Plumbago. Grows in compact clumps, and from the middle of July until severe frosts are covered with lovely, rich, violet blue colored flowers, borne in close terminal heads. The foliage is unique, finely serrated and fringing the stems. We heartily recommend this fine variety for edging walks, beds or borders. Price, 10 cents each.

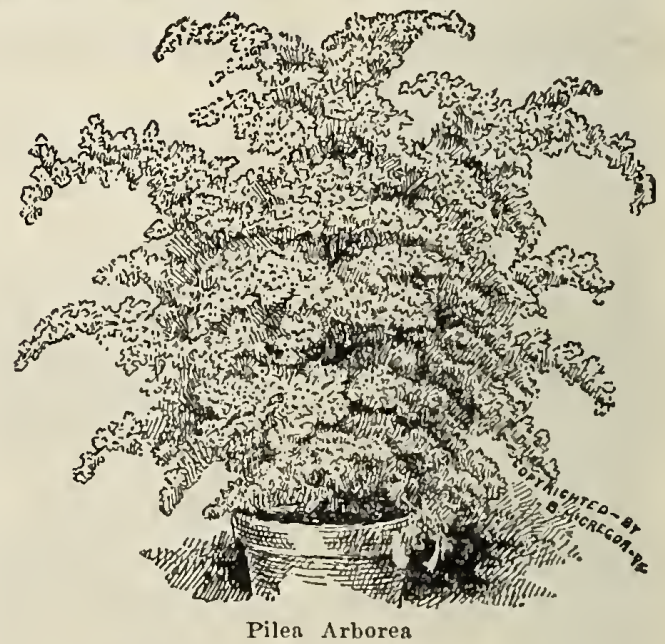

\section{Pilea Arborea}

\section{(Artillery Plant)}

A pretty little plant of drooping, graceful liabit and fern like foliage, literally covered with very small, pretty flowers, giving the plant $a^{\prime}$ pleasing effect; fine basket or pot plant. Price, 10 cents each.

OUR GIIARANTEF We guarantee all plants to reach condition. 
JOS.W.VESTAL \& SON OY TITLE ROCK,ARK.

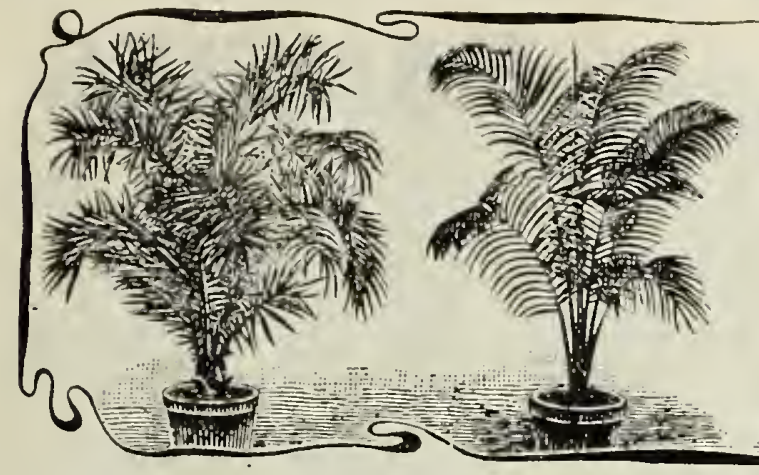

Phoenix Reclinata

\section{PHOENIX RECLINATA}

$A$ fine large growing, graceful Palm of easy growtl, and one that will stand much neglect without injury. Price 50 cents each; larger, 75 cents each.

\section{ARECA LUTESCENS}

Its graceful, recurved and pinnatified, glossy green frouds make it a most pleasing object. The trunk or stems become more or less yellow with greenisl spots, an added feature of beauty. Price, 50 cents each; from five inch pots, 75 cents each.

\section{LATANIA BORBONICA}

The well known favorite Fan Palm. It is easily grown. and is rery tenacious of life, enduring the dust, the cold and heat from open windows, and gas heated air of our dwellings. It has fan slaped leaves, split into divisions at the apex. It is a strong, vigorous plant, and makes a fine appearance. Price, four inch pots, 35 cents each; larger sizes, 50 cents, $\$ 1.00$ and $\$ 2.00$ each.

\section{CYCAS REVOLUTA}

The Cycas makes a magnificent specimen plant and is one of the most valuable plants grown for decoration of the lawn or house; their heavy glossy deep green fronds resist alike the alike the gas, dust and cold to which decorative plants are
frequently exposed. Fine shapely plants. Plant with frequently exposed. Fine shapely plants. Plant with leaves, $\$ 1.50$. plants with ten to fifteen leaves, $\$ 2.50$.

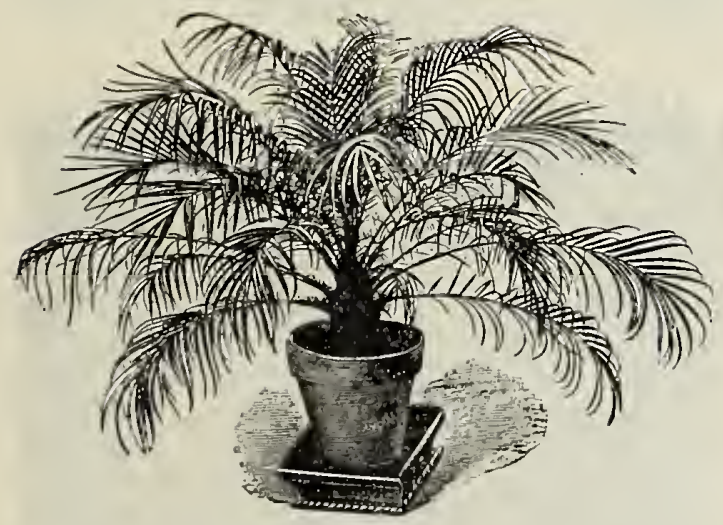

Phoenix Roebelini

\section{PHOENIX ROEBELINI}

A new Palm is always interesting, but when the new comer is easily the most graceful and withal the hardiest, it is little short of sensational. The horticultural world has enthused over this beautiful Palm. It has the grace and lightness of Cocos Weddelliana, but is more robust in growth, and has tenfold the foliage of that fne robiety. It is essentially different from it foliage from the variety. up gracefully recurved and spreading in habit. It will be most popular for house decoration. Price, 50 cents each; large plants, $\$ 1.00$ each.

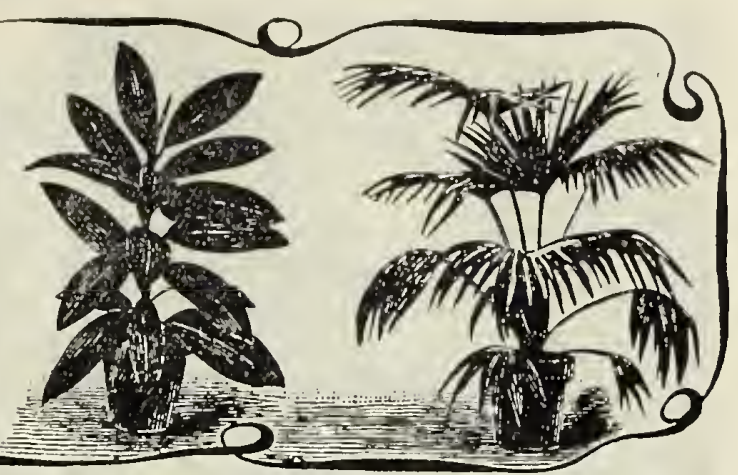

Ficus

Latania Borbonica

\section{FICUS ELASTICA}

INDIA RUBBER PLANT.

Very large, smooth, leathery leaves; evergreen foliage. The plant attains a large size and tree shape. Each new lcaf is inclosed in a long coral red envelope, looking like a great red flower bud. Price, 40 cents each; large plants, 75 cents each. We can also supply Ficus Elastica Varlegata and Ficus Pandurata at $\$ 1.00$ each.

\section{COCOS WEDDELLIANA}

This is one of the most elegant and graceful of all the smaller palms; its slender, erect stem is freely furnished with its graceful arching fronds and fine deep green leaves. The Cocos is quite hardy and easily grown and is highly valued as a very choice table and parlor orna ment. Price, nice plants, 50 cents each.

\section{KENTIA BELMOREANA}

Best in its elass-graceful habit, bright green foliage, gracefully disposed. Price, elegant plants out of four inch pots, 50 cents each. Beautiful specimens from six inch pots, $\$ 1.00$ and $\$ 1.50$ each.

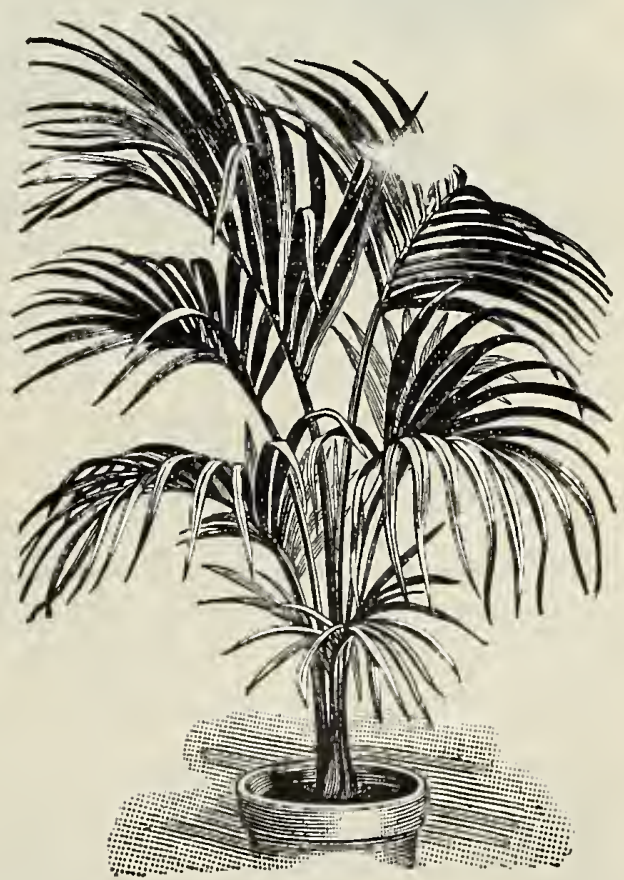

Kentia

\section{KENTIA FOSTERIANA}

It is not injured by slight changes in tcmperature, and its stiff, glossy leaves enable it to stand the dry, hot gir of the living room without injury. The leaves are deep glossy green, fan shaped, split dceply into segments. Price, handsome plants from four inch pots, 50 cents each. Nice specimens from five and six inch pots, $\$ 1.00$ and $\$ 1.50$ each. 


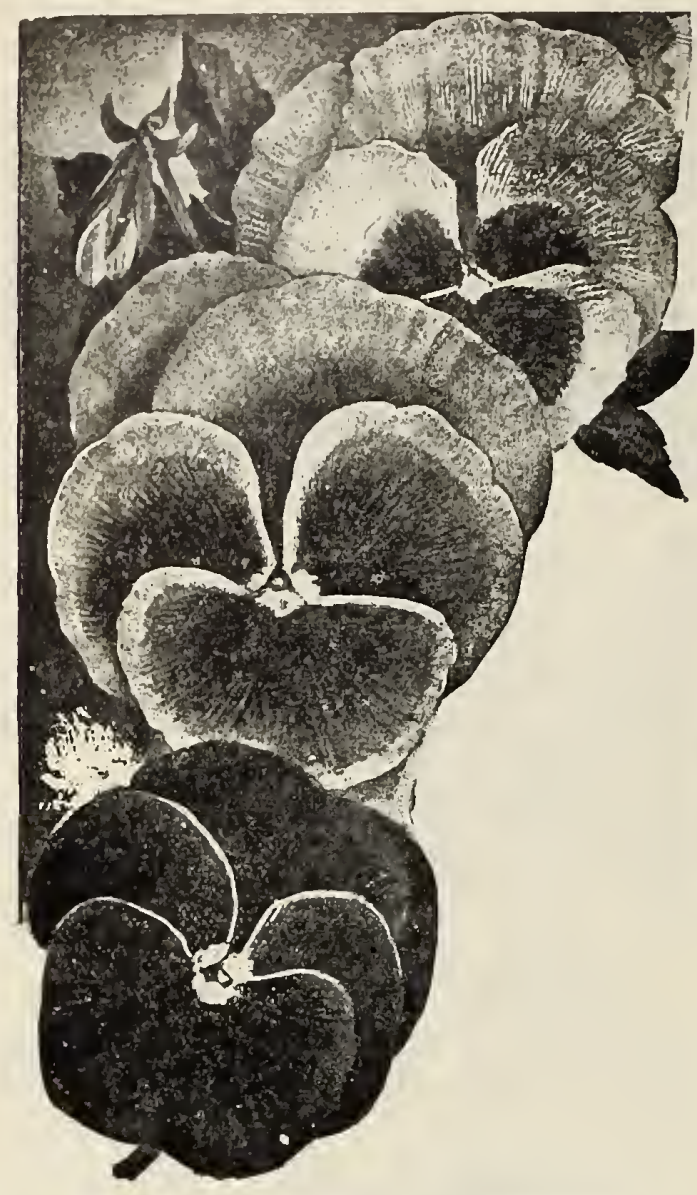

\section{TWO SPLENDID SETS OF TUBEROSES}

SET No 1. For fifty centa, we will send by mail, postpaid, 10 Tuberoses, selected as follows: 6 Excelsior Pearl, 2 Armstrong and $2 \mathrm{New}$ Variegated Leaved, 10 in all, for 50 cents.

SET No. 2. For one dollar, we will send by mail, postpaid, 22 Tuberoses, selected as follows: 12 ExLeaved, 22 in all, for $\$ 1.00$

\section{Hardy Phlox}

(Early Flowering.)

PRICE, 10 CENTS EACH; $\$ 1.00$ PER DOZEN.

These we consider the most desirable of all hardy per ennials, flowering abundantly from June until late in autumn

AURORA BOREALIS. Clear pink, erimson eye. AQUILLION. Carmine rose, shaded salmon; crimson

ALCESTE. White, shaded lilac; blush center. ALICE PEARSON. Clear pink with crimson eye. BERNICE. Pure white; compact heads. BRIDESMAID Pure white; large crimson center. COQUELICOT. Fine orange scarlet with deep carmine

CHAMPS ELYSEE. Rich dark Crimson,

ECLAIREUR. Purplish crimson with white halo. HENRI MURGER. Pure white; bright rosy eye JEANNE D'ARC. A fine free flowering white. PANTHEON. Deep salmon rose; very fine. PROF. SCHLIEMAN. Salmon rose; carmine eye. PEARL. Large, perfect, pure white flowers. The im. mense flower heads are in breadth almost equal to the lieiglit of the plant.

\section{OUR

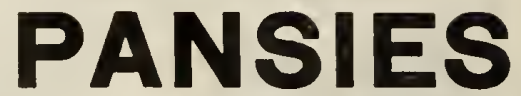

Price, 5 cents each; 50 cents for ffteen; $\$ 2.50$ for 100 .

Pansies have been one of our specialties for a number of years. The combination of colors in the same flowers is exquisite and wonderful, and yet so delicate that no description can convey an adequate idea of thcir beauty. embracing so many varieties-striped, spotted, bordered and fringed: in rainbow colors, with rich, velvety textures; some light yellow with deep violet spots, the upper petals carmine, edged with white; yellow with crimson maroon spots and blue rims i deep blue with yellow center, edged black; violet with white center and carmine cdges; brown and golden bronze; jet black; ultramarine blue; pure white; intense yellow.

Pansy plants planted in the spring as soon as the frost is out of the ground will begin to bloom at once, and afford daily pleasure for a month before Coleus or Ger. aniums could be even planted. If snow should fall after planting they would not be hurt. In fact, to get the best results from Pansies, they should be planted just as early as they can be. To get best results and extra large flowers, the soil must be extremely rich-we use equal parts well rotted manure and soil.

\section{DOUBLE DWARF \\ "PEARL" TUBEROSE}

Pure white; perfectly double; delightfully fragrant; invaluable for boquets. Manure, heat and water are essential to its perfect development. Grows only 24 inches high, and flowers are nearly twice the size of the double sort, imbricated like a Camellia. Price, 5 cents each; 50 cents per dozen.

\section{"SILVER LEAF" TUBEROSE}

Showy and effective, even when not in bloom, the foliage being distinctly striped white and green. Each bulb frequently throws up two or more spikes, three to four feet high, each bearing from twenty-five to forty pure white, waxy flowers, much like an orange flower or Stephanotis, with a delicate and enchanting perfume. They flower several weeks earlier than double Tuberoses, and the bulbs bloom year after year. Price, 5 cents each; 50 cents per dozen.

\section{ARMSTRONG'S BRANCHING OR}

\section{MEXICAN EVERBLOOMING TUBEROSE}

A single white Tuberose. It begins to flower in July and August throwing from two to five flower stems from a single bulb. The petals recurve gracefully. The odor is less heavy than that of the ordinary Tuberose. Price, 10 cents each; $\$ 1.00$ per dozen.

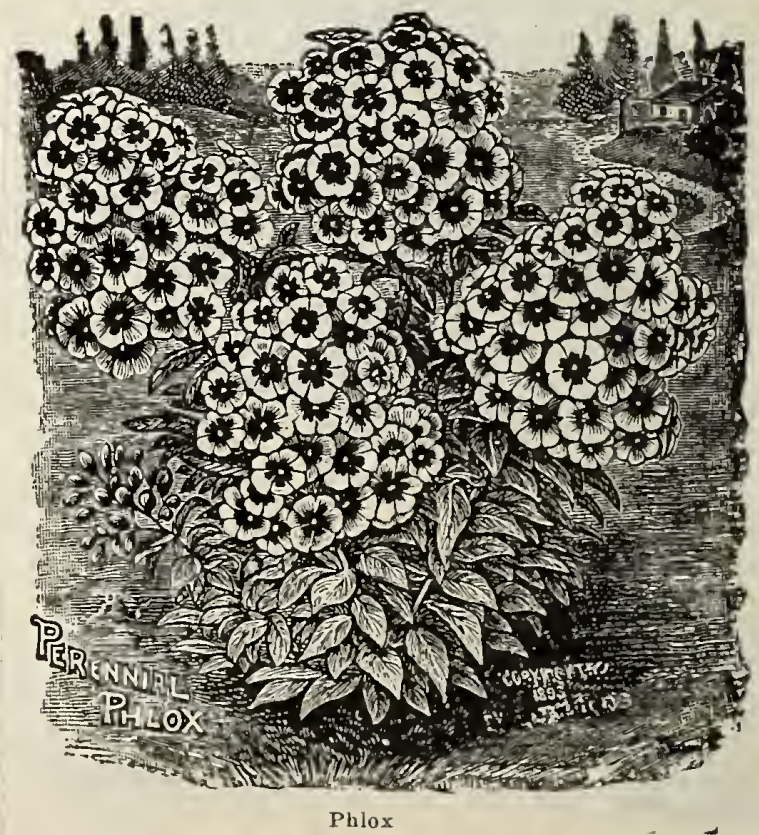




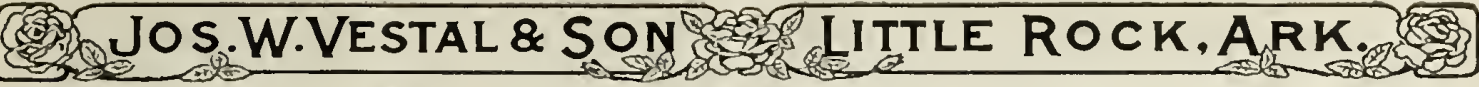

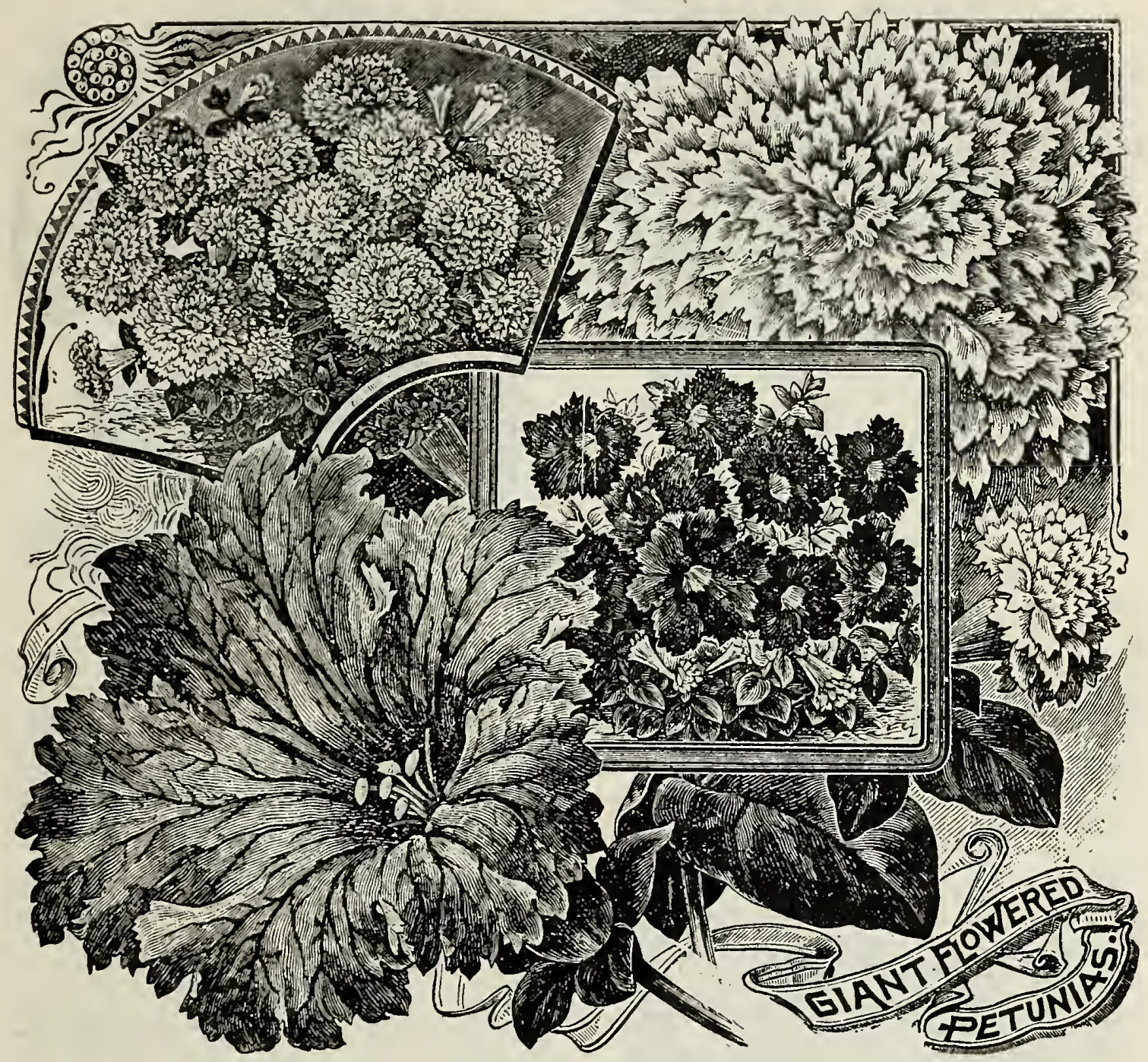

GIANT DOUBLE

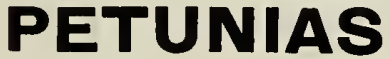

Are as large as Hollyhocks; as double as double can be, with edges finely fringed, petals fluted and crinkled, intensifying and varying the colors with high lights and dark shadows, bringing out a richness and effect uninatched by crumpled velvet, which the flowers resemble. There is a variety of colors-selfs, blotched, veined margined, etc, in short, these double Petuniss are unsurpass. ed by any other strain in the world. Price, 10 cents each; $\$ 1.00$ per dozen.

\section{SANTOLINA TOMENTOSA}

A most neat and effective white border plant, forming dense, compact bunches, not over six inches high, and crom six to ten inches in diameter. This is a fine companion to the Alternantheras, growing the same height and contrasting finely. Price, 5 cents each; 50 cents per dozen.

\section{SMILAX}

This handsome and eraceful climber is a great addi. tion to our basket plants, possessing the rare qualities of delicate and tolerably dense folising the rare qualities of mirably adapting it to climbing or drooping. For using as a green for cut flowers it has no equal. Price, 5 cents each.
LARGE FLOWERING SINGLE FRINGED PETUNIAS

The Single Petunia is one of the finest bedding plants for massing, mixed borders, or for vases. The brilliancy and variety of its colors, combined with the duration of its blooming period, render it invaluable for garden decoration. Our collection is unsurpassed for brilliancy of color and size of bloom. It includes all the brightest shades of pink, purple, rose, white, etc. Price, 5 cents each; 50 cents per dozen,

\section{STEVIA}

SERRATA. A pretty flowering plant. Largely grown by florists in pots for blooming in the fall and winter. Plants are of upright growth, producing numerous sprays of small white florets of delightful fragrance. Not hardy and therefore should be potted in the fall for winter blooming. Price, 15 cents each.

\section{SANSEVIERA ZEYLANICA}

Too much cannot be said in favor of this docorative plant. There is none so beautiful in foliage, and fow that will stand neglect so well; leathery, sword like leaves. elegantly marked with bars of silvery gray. Price, 16 cents each; larger, 30 cents each. 


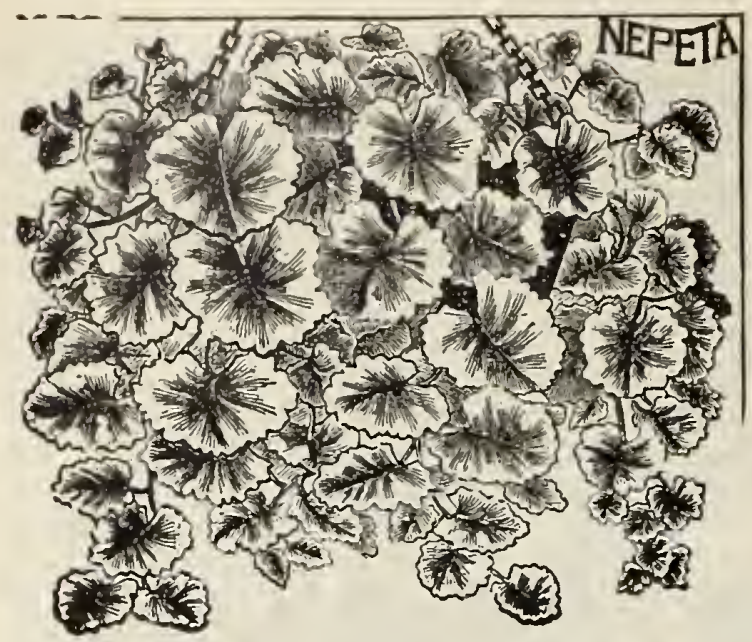

\section{NEPETA GLECHOMA}

\section{VARIEGATED GROUND IVY}

This new Nepeta is hardy, fragrant and pretty, its small round leaves finely marked with white. Very fine for hanging baskets, standing any abuse and looking cheerful under it. One of the prettiest things in the world with which to carpet graves, as it roots wherever it touches the ground and forms an impenetrable network of vines, through which weeds and grass cannot creep. It will grow in any kind of soil, in sun or shade, hot or cold location, and is ever a mass of green and white, refreshing to the Price, 10 cents each; three for 25 cents.

\section{RUSSELIA ELEGANTISSIMA}

New. A rery striking, semi-trailing plant, expressly adapted for hanging baskets, vases or window boxes, where a delicate, graceful effect is sought. The plant is skeleton like in growth, throwing long spikes of rush like branch. ing foliage, two or three feet long, which are literally covered with brilliant coral red florets. Well grown of delicate coral blossoms. Price, 10 cents each.

\section{TRADESCANTIA}

Tradescantia (called Wandering Jew) have beautiful marked foliage, and are fine for hanging baskets and vases, or for house culture, as they will endure most any hardship if liberally supplied with water. Price, 5 cents each.

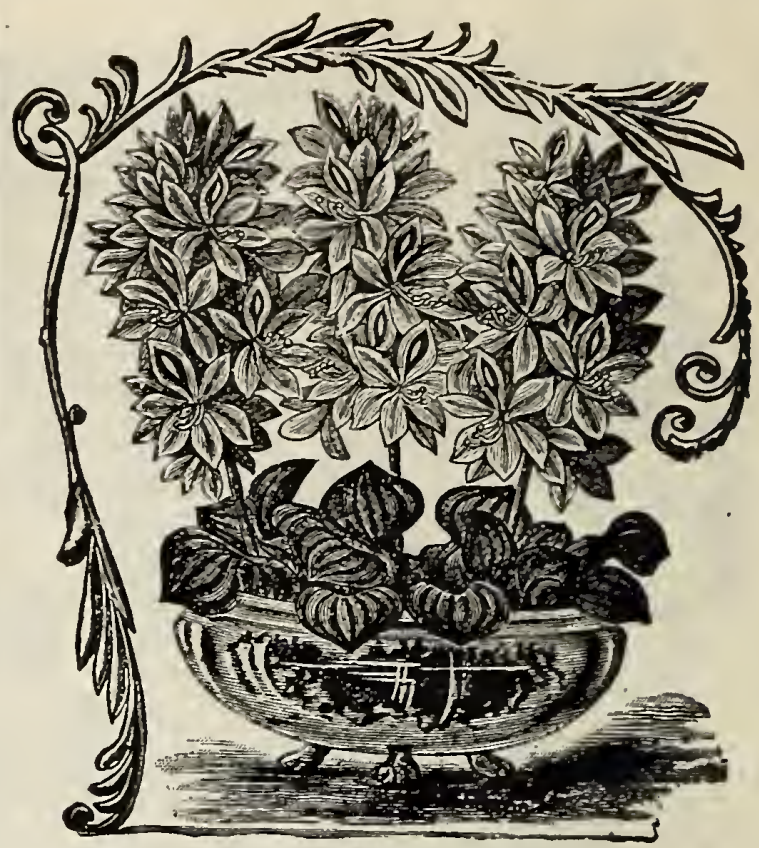

Water Hyacinth

\section{WATER HYACINTH}

Easily grown; floats on the water by means of curious inflated leaves, a mass of feathery, blue roots growing downward in the water. The flowers, as large as a silver dollar, are borne on spikes six to eight inches long, re. sembling hyacinths, and are as handsome as an orchid: of a beautiful sparkling, rosy lilac color. Price, 10 cents each.

\section{VIOLETS}

PRINCESS OF WALES. New single violet. This variety is far ahead of any other single violet known. Of hardy, vigorous growth, the plants are wonderfully free flowering, with stems from ten to twelve inches long; lawe grand single fowers of a true riolet blue color that does grand single fowers, of a true violet blue color that does not fade, are of round, symmetrical form, almost as large as pansies and of the richest, most delicious fragrance. will cover a silver dollar. Price, 10 cents each; fifteen for $\$ 1.00$.

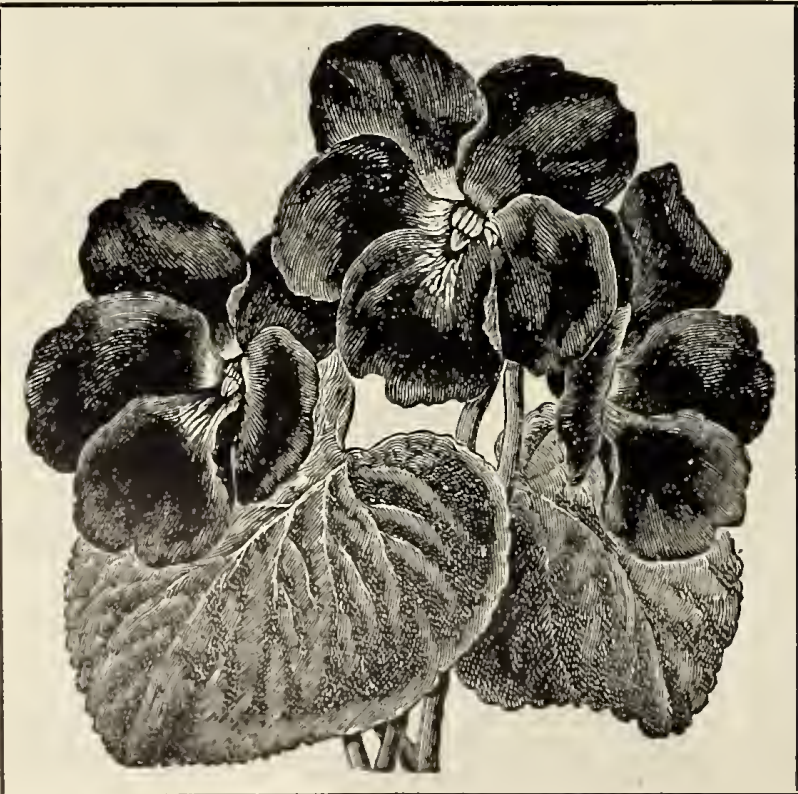

NEW SINGLE VIOLET

\section{Governor}

\section{Herrick}

This variety is far ahead of any other single violet known. Of lardy, vigorous growth, the plants are wonderfully free flowering. with stems from ten to twelve inches long; large green leaves of a thick leathery texture. The grand single flowers, of a true violet blue color that does not fade, are of round, symmetrical form, almost as large as pansies, and of the richest, most delicious fragrance. So large and circular are the flowers that some blooms will cover a silver dollar. Price, good strong plants from 3 inch pots, 15 cents each; 4 for 50 cents; $\$ 1.00$ per dozen. 


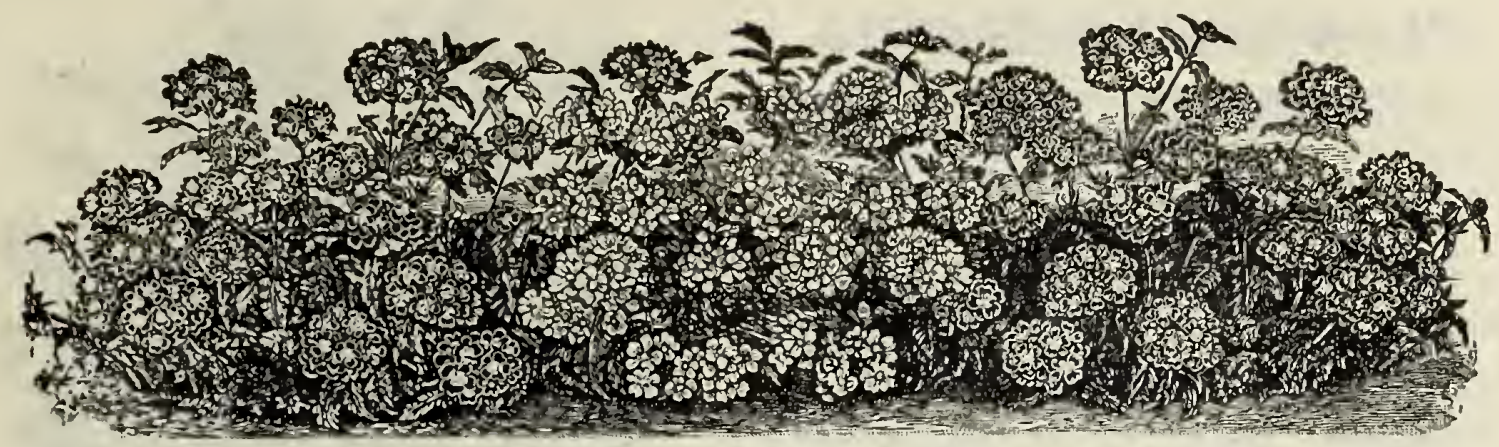

OUR UNRIVALED

\section{MAMMOTH VERBENAS}

Next to the Geranium tbe Verbena is the most popular and useful of bedding plants. The collection we offer is as fine a collection as could be found on this continent, containing the most brilliant colors and some right fragrant varieties. In order to keep the plants in the best blooming condition, cut all faded flowers off, and even a severe trimming or In order to keep the plants in the best blooming condition, cut all faded flowers off, and even a severe trimming or
clipping tends only to strengthen the plants and keep them in better shape for late flowering. The demand we bad the past season for this popular flower was enormous.

PRICE, 5 CENTS EACH; TWELVE FOR 50 CENTS; THIRTY FOR $\$ 1.00$

AMETHYST. Rosy lilac; very free bloomer; one of the very best.

BLUE BOY. As the name implies, it is a magnificent, large flowering blue variety. It is indeed a beauty.

BEAUTY OF OXFORD. Large pink; well known favorite.

BRIDESMAID. Pink. A magnificent Verbena; extremely large; soft glowing pink with white eye.

BLACK HAWK. Very dark maroon.

CRIMSON KING. Blood red. This is without doubt the most brilliant colored of any flower that grows. It is very large and such a vivid red that it really dazzles the eye to look at it.
DAISY DAIE. Carmine; very large.

LE PILOT. Most brilliant scarlet, large bold eye, foliage dark green.

MODIST. Beautiful large flowers of exquisite heliotrope sbade.

MONSTRosUM. Very large red; large white eye; one of the best.

PINK STAR. Extra large flowers of clearest bright rosy pink; one of the most admired varieties.

SNOW STORM. Pure white. This is tbe most beauti ful of all the white large flowering verbenas.

SPECIAL OFFER FOR FIFTY CENTS WE WILL SEND FIFTEEN CHOICE MAMMOTH VERBENAS IN SPLENDID

\section{VINCA}

VARIEGATED LEAVES.

An elegant low growing, climbing vine; brigbt, glossy green leaves, widely bordered with creamy white; extra nice for pots, vases, baskets, window boxes and rockeries: good everywhere; always wanted. Price, 10 cents each: six for 50 cents; twelve for $\$ 1.00$

\section{VINCA HARRISONI}

A variety of strong growth; margin of leaves rich, dark green, with the central portion light green, furnishing an abundance of star sbaped, light blue flowers. Price, plants suitable for hanging baskets, 15 cents each; extra large, for vases, 25 cents each.

\section{TRAILING MYRTLE}

An evergreen trailing vine, with small green leaves, and small sky blue flowers. Price, 10 cents each; $\$ 1.00$ per dozen.

\section{GOLDEN MYRTLE}

It is a golden variegated sport from the green trailing Myrtle. Tbe leaves are larger than the green Myrtle, margined with beautiful rich golden yellow. It is ver desirable for cemetery work, rockeries, slopes, banks borders for sbrubbery, window boxes, etc. Price, 15 cents each; $\$ 1.50$ per dozen.

\section{MONEYWORT}

A beantiful trailing vine witb small green leaves, suitable for hanging baskets, vases or covering graves. Price, 5 cents each; 40 cents per dozen.

\section{ENGLISH IVY}

A splendid evergreen climber, with dark glossy green leaves; clings firmly to stone or brick walls, without trellis or support, covering them closely with its splendid foliage: very desiralle. Price, 15 cents each; large size, 25 cents each.

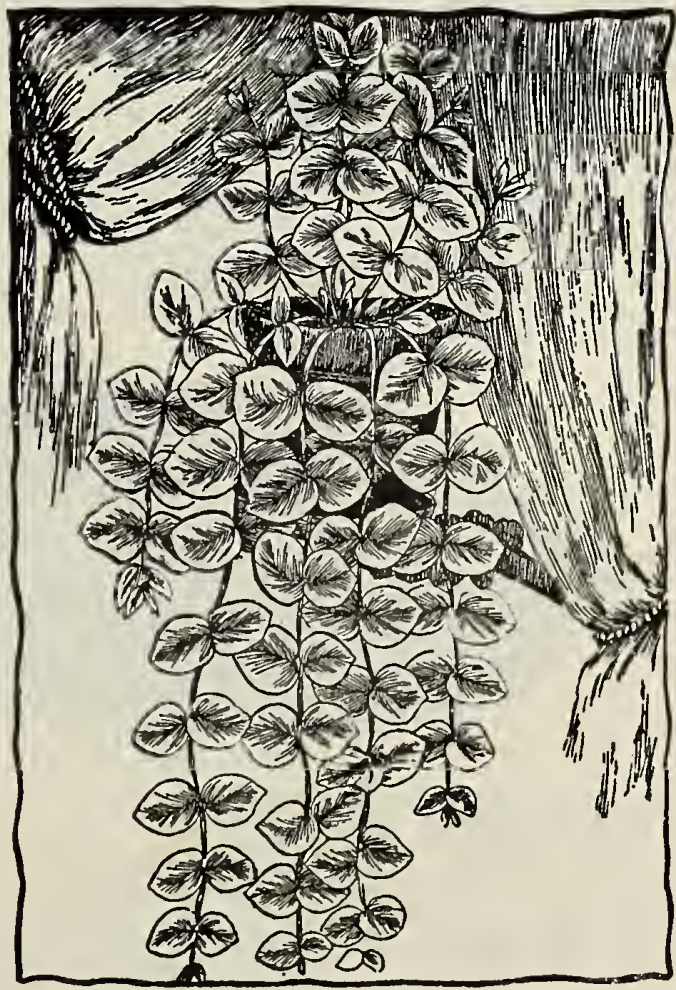

Vince 


\section{New Dwarf Salvia}

ALBERT RAGNEAU. This variety we consider the best of the dwarf varieties of late introduction, and in fact the only true dwarf one. The flower and foliage is the same as the old rariety Splendens, but in growth it is much dwarfer, making it more valuable for bordering beds, etc. Price, 5 cents each; 50 cents per dozen.

SILVERSPOT. The distinctive feature of this splendid novelty is its strikingly handsome spotted foliage. The leaves are rich, soft, lark green, with light sulphur or cream colored spots of rarious sizes liberally sprinkled over them. The intense, bright scarlet flowers are very large. Price, 5 cents each; 50 cents per dozen.

FIREBALL. This grand new Salvia retains its bright. ness and profusion of bloom as well in July and August as in September and October. Its height is about eighteen to twenty-four inches. One well known gardener of Little Rock described it as a Salvia, Geranium and Coleus all in one, as it always makes a show. Priee, 10 cents each; three for 25 cents; 75 cents per dozen.

\section{SAXAFRAGA SARMENTOSA}

A very handsome plant of low habit, leaves nearly round and striped freely with silver bands; blooms white, of great beauty and borne in spikes nearly twelve inches high. Fine for hanging baskets, vases, etc. Price, 10 cents each.

\section{Holt's Mammoth Sage}

A single plant will yield more than a dozen plants of the common sage. It is perfectly hardy. Rarely flowers; never runs to seed. Príce, 10 cents each; three plants
for 25 cents; seven for 50 cents; fifteen for $\$ 1.00$.

\section{MINT}

New English variety with three times the aroma of the old variety. A useful herb for flavoring. This is the variety used in making the famous Mint Julep. Price, 5 cents each; 50 cents per dozen.

\section{CATNIP}

Leaves and young shonts are used for seasoning. Also used as a mild nervine for infants. Price, 5 cents each; 60 cents per dozen.

\section{ROSEMARY}

A popular herb. The aromatic leaves are used for seasoning soups, etc. Price, 5 cents each.

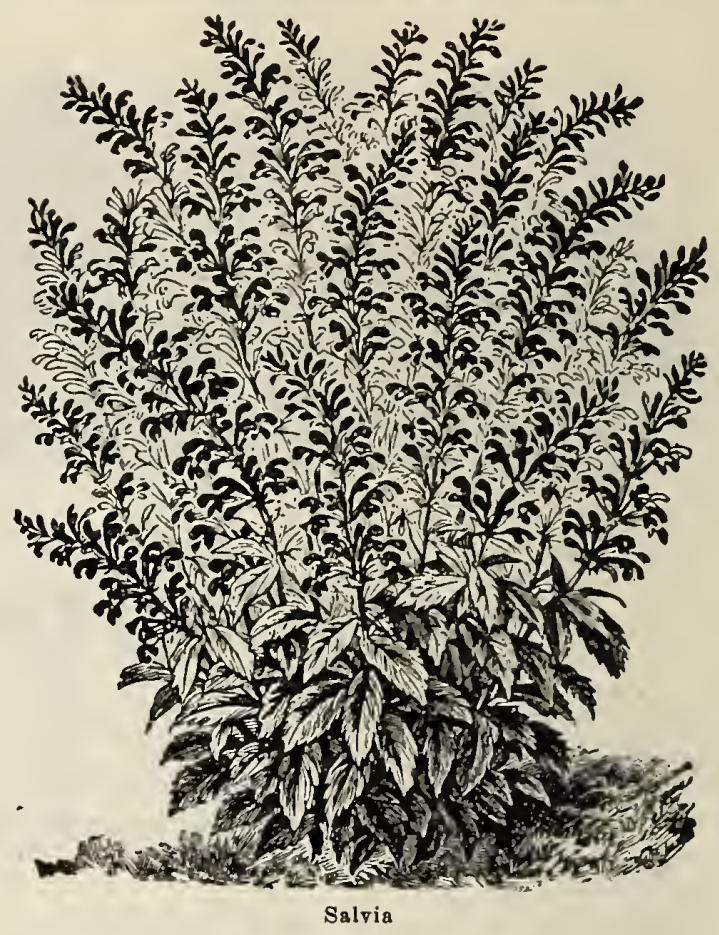

\section{THYME}

Variegated gold and silver leaved, pretty rariegated varieties of the common Thyme, equally fragrant and ornamental; is perfectly bardy. Price, 10 cents each.

\section{A PLEASANT SURPRISE $\$ 3.00$ WORTH OF PLANTS FOR}

AFTER MAY 1st and until June 1st we will send, to any address, $\$ 3.00$ worth of plants, of our selec tion, at regular catalogue prices, for only $\$ 1.00$.

How can we afford to do it? To make sure of having enough plants and not become sold out before the end of the season, we are compelled to grow great quantities, and often have some left over. Of course we can not tell in advance what these will be, but we will make you up a nice assortment, entirely our selection, of good strong plants.

P. S.-Please ask for the "Pleasant Surprise Collection" and send us $\$ 1.00$ now, or any time before June 1st, and your order will be carefully booked and shipperl as soon as its turn can be reached beginnins May 1 st.

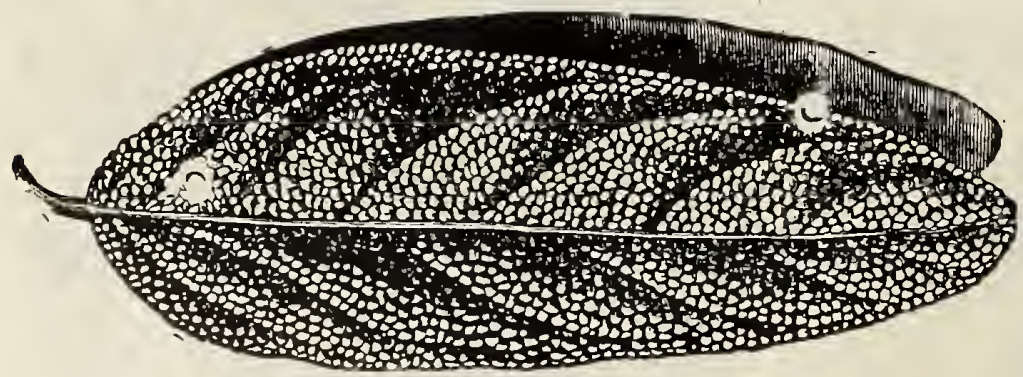

\section{CORCHORUS JAPONICA}

\section{KERRIA}

A slender, green branching shrub, four to six feet high, with globular. yellow flowers; blooms from June to October. Price, 15 cents each.

Holt's Mammoth Sage

NEW EUSTOMERS As this Catalogue will reach many who have never had our plants, we would urge such to send HEW UUJ IMERS us a trial order, no natter how small, and although you may be satisfied with plants bonght elsewbere, we believe our special strains of many of the newer varieties will make them as profitable to you as they have been to thousands of others who are now regular customers.

IN BUYING ROSES Buy them as you would anything else-keeping in mind that the cheapest is often the dearest in you are safe, both as regards prices and quality. Our stock for this season's trade was never in better condition or larger supply. 


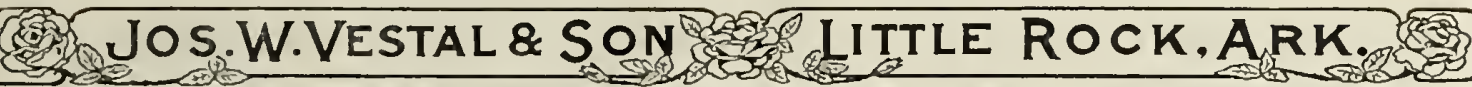

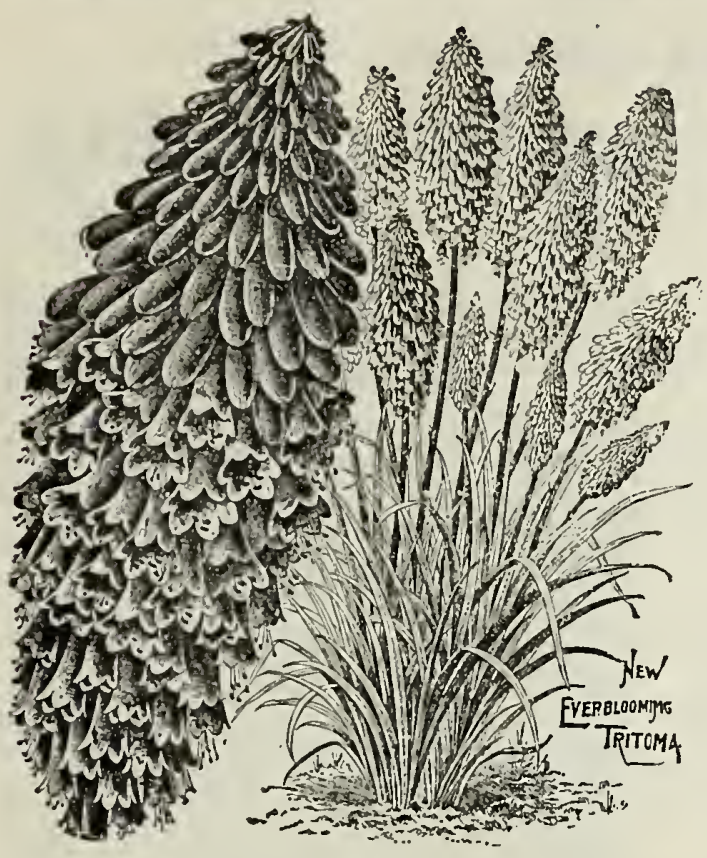

\section{Tritoma Pfitzerii}

The best variety. The flower spikes, which are produced with considerable more freedom than in the old variety are of gigantic size, frequently four and one-half feet high, with heads of blooms over twelve inches long of a rich orange scarlet, shading to salmon rose on edge. Price, 25 cents each; five for $\$ 1.00$.

\section{Funkia \\ Day Lilly}

The roots should be set out in the autumn to become well established, and they will bloom the following spring. They need not be disturbed for many years, and will always be welcome for tbeir graceful beauty and fragrance

ALBA. (White Day Lily.) Price, 20 cents each; $\$ 1.00$ per dozen.

BLUE. Price, 20 cents each; $\$ 1.00$ per dozen.

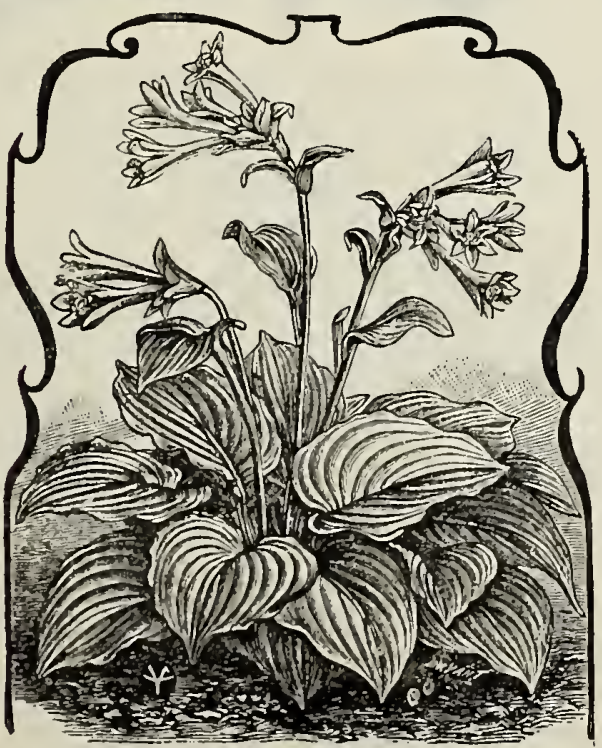

Funkia

\section{PAEONIES}

Once planted they will last a lifetime with little carc. They cent blooms, which sometimes almost surpass the besuty of the Rose. Another point which is largely in tbeir favor, is the fact that the plants are never attacked by either in sects, animal or fungal disease. Paeonies will succeed in most any kind of soil, but give best results when planted n a deep rich and somewhat moist loam.

FIRST PRIZE WHITE. Has immense pure white blos soms, with carmine flaked tips to a few center petals. It begin to fade by the First Prize pink.

FIRST PRIZE PINK. Blossoms immense, on long stiff stems, and in color almost identical to a La France Rose.

FIRST PRIZE RED. This beautiful variety resemble the American Beauty Rose in color, succeeds the First Prize Pink, extending the flowering period for Paeony blossoms almost two months.

Price, double white, 35 cents each; double pink and red, 30 cents each. One each of the three varieties, 85

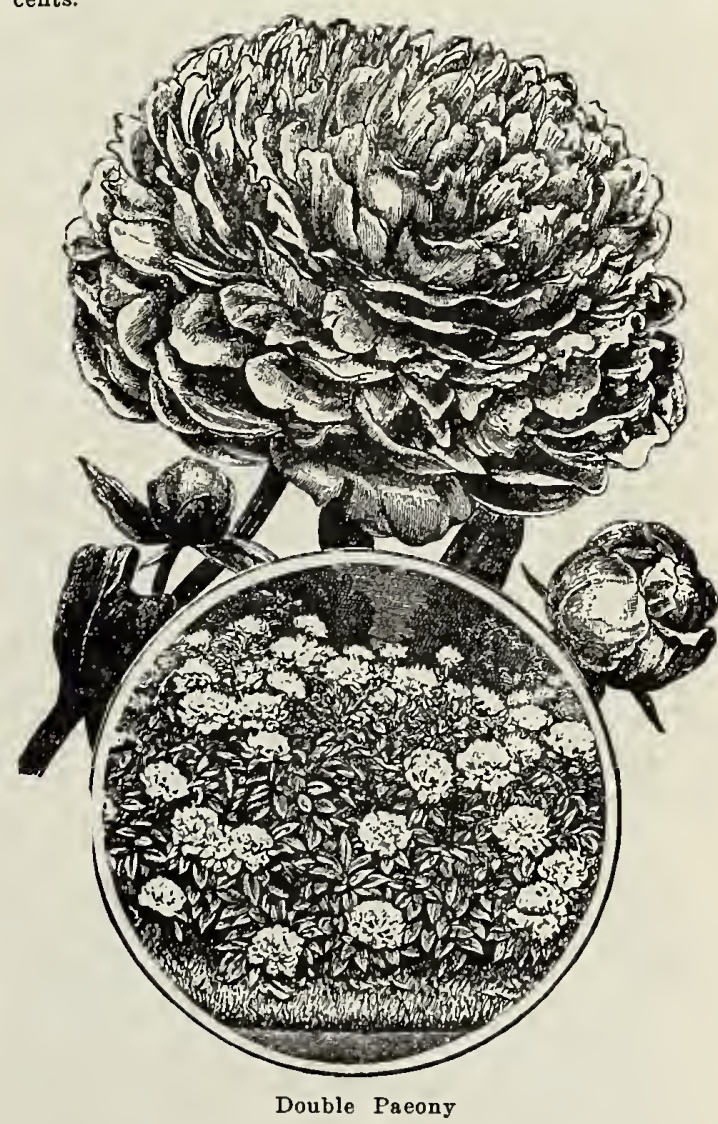

JAPAN IRIS

The magnificence of these new Iris surpasses description The flowers are of enormous size, averaging eight to ten inches across, and of indescribable and charming hues and colors, varying like watered silk in the sunlight, the prevailing colors being white crimson the sunlight, the violet and blue being white, crimson, rose, lilac, lavender, violet and blue; each hower usually representing several sbades, while a golden yellow blotch, surrounded by a halo of blue or violet, at the base of the petals, intensifies the wealth of coloring. The Japan Iris is perfectly hardy 15 cents each; four for 50 in

\section{GERMAN IRIS}

Blooms earlier than Japan Iris. This variety is the true "Fleur de Lis," the national fiower of France. They are perfectly hardy, thrive anywhere, deliciously fragran and fine for cutting. In beauty the flowers rival the finest Orchids, the colors ranging through richest yellow, intense purples, delicate bulbs, soft mauves, white and bronze of every imaginable shade. We offer five distinct colors. Price, 15 cents each; two for 25 cents. 


\section{ORNAMENTAL AND FLOWERING}

\section{Shrubs, Vines, Hedge Plants, Etc.}

The best investment a lome owncr can make is in a judiciously selected order for shade trees, shruhs and plants to embellish and beantify the lome, no matter how humble and plain it may be. There is no other kind of improvement where a little money goes so far and adds so much rcal value in a few years.

Whether you have a lawn of many acres or a humble door yard, we commend this class of plants as indispensable to the real beauty of your lome. If you select with care you can have a succession of hloom from April to November, to, say nothing of the beautiful color, form and shadow effects of flowers, foliage and bright berries. For planting along horder lines, filling in or rounding off angles, or for screens to hide fences or other unsightly objects, you will find nothing more permanently pleasing than varieties listed below. They may be planted with equal success, either individually or in groups.

SELECTION AND ARRANGEMENT. In selceting and arranging ornamental trecs and shrubbcry, the character and style of growth of each tree and plant slould be noted and considered. The larger and more rapid growing kinds should be planted sufficient distance apart and from buildings to prevent crowding and growing into unshapely forms. Deciduous and Evergreen Shade Trees should be intcrspersed so that you will get the henefit of the additional shade in summer and light in winter, but with Evergreen Trces so placed that the yard or grounds will not look bare when leaves are off the deciduous kinds. Small trees and slurubs are best grouped in open spaces bctween the larger and near building. Small growing evergreen trecs, especially those adapted to shaping into fancy heads, can be utilized to advantage either singly or in groups.

Conform to nature as closely as conditions will allow, avoid straight rows and square setting unless for street planting, and occasionally for hedges, borders and avenues. Graceful curves winding between the larger growing specimens is more pleasing and artistic than straight drives, walks and rows.

The kind we offer are limited to those that, with moderate carc, give the best results in the South. While we do not offer many of the new introductions, novelties and untried kinds, yet you will find in our list sufficient sorts for beautifying most magnificent grounds, parks and estates. We are adding to this list as tests how the adaptability of other orts. With such a list to select from, and with the knowledge from years of experience, we can please you.

\section{Magnolias}

MAGNOLIA GRANDIFLORA. In its southern home this grandest of broad leaved evergreens grows to 75 or 100 feet high and displays hundreds of its great white flowers for two months or more of spring. Their rich, flowers for two months or more of spring. Their rich, established trees the blossoms are from 9 to 12 inches across, and sometimes the profuse spring bloom is succeeded by an aftermath of splendid flowers in August or October. The leaves vary in width, but are always large and lustrous, vying with those of the palm and rubber tree when used in winter decorations. The hardiness of this Magnolia is underestimated. Good specimens are found on Long Island and in northern Pennsylvania. We have had temperatures of 17 degrees below zero, which did not injure it. With this evergreen, as with many other beautiful trees now grown everywhere, it will be found that, in cold climates, protection given while it is young helps to form a fine tree that may prove hardy when established. The roots need wide room and rich soil to bring out the fullest beauty of the tree, which soil to bring out the fullest beauty of the tree, which should be transplanted carefully in early spring.
one foot high, 35 cents each; three to four feet, $\$ 1.00$ one foot
each.

\section{EUONYMUS}

BROAD LEAVED JAPAN EUONYMUS. (Euonymus Japonicus.) It is not generally known that in warm climates this handsome foliage shrub bears a profuse crop of pink capsuled herries, which are reflected over and over in its broad, mirror-like leaves. It is perfectflowering, too, so that it does not necd to be planted in guantity to insure a hright winter crop. Price, one foot quantity to insure a hright winter crop.
high, 25 cents each; $\$ 2.50$ per dozen.

EUONYMUS AUREA-VARIEGATA. (Varicgated Eunymus, Leaves beautifully variegated with golden yellov. Valuable where lively effects are desired, or for jardinieres. Price, one foot high, 40 cents each.

E. ARGENTEA VARIEGATA. Variegated variety, with leaves conspicuously margined with white, and constant in its colorings. Price, one foot high, 25 cents each.

PULCHELUS. A very dwarf plant with small leaves. scarcely ever exceeding eight to ten inches in height. Price, 15 cents each.

We can supply any of the above Euonymus, eight to ten inches, for hedging, at $\$ 5.00$ per 100 .

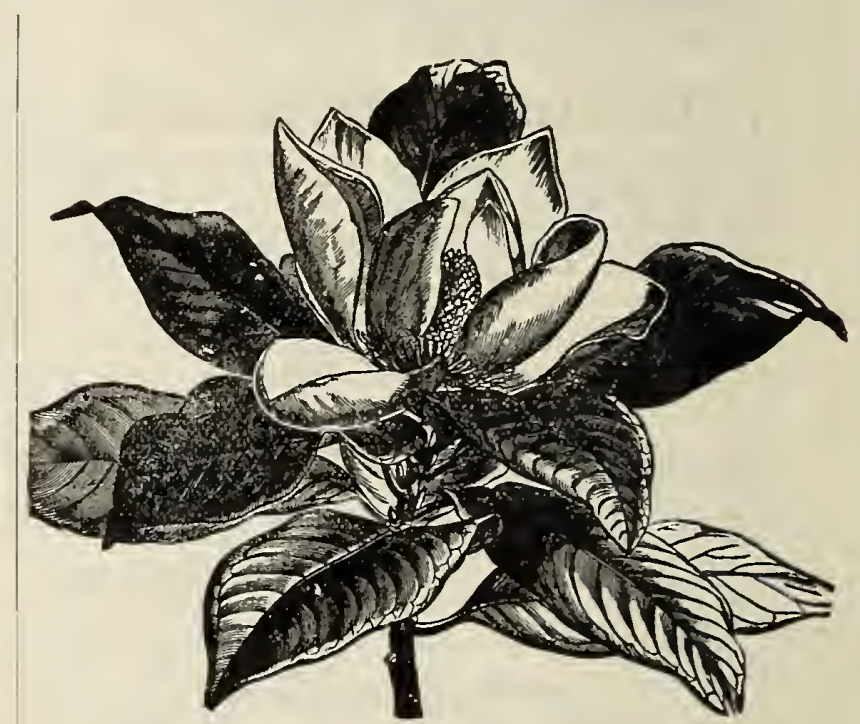

Magnolia Grandiflora

\section{BUXUS}

The Boxwoods

Thesc beautiful shrubs have been extcnsively used for hedges in formal gardens, and as specimen plants for lawn and landscape. They are justly popular, hardy evergreens that thrive in all save the extreme northern portions of the country. A well-drained loamy soil is best adapted to their requirements, and for specimen plants it is advisable to select a situation in partial shade. This species is used for single specimen plants, and is often trimmed into architectural or fantastic shapes. Price, one foot, 25 cents each; six to eight inches for edging, $\$ 5.00$ per 100 .

\section{Six Hardy Shrubs for Only $\$ 1.00$ \\ EXCELLENT FOR LAWN DECORATION}

ALTHEA. " "Rose of Sharon."

SPIREA. "Anthony Waterer."
HONEYSUCKLE. Swcet scented.

DEUTZLA. Tsemoineii.
WEIGELIA. "Pink."

WISTARIA. Magnifica.

THE QUALITY OF THESE SIX PLANTS FOR \$1.00 WILL SURPRISE YOU. 


\section{THE FEATHERY RETINOSPORAS}

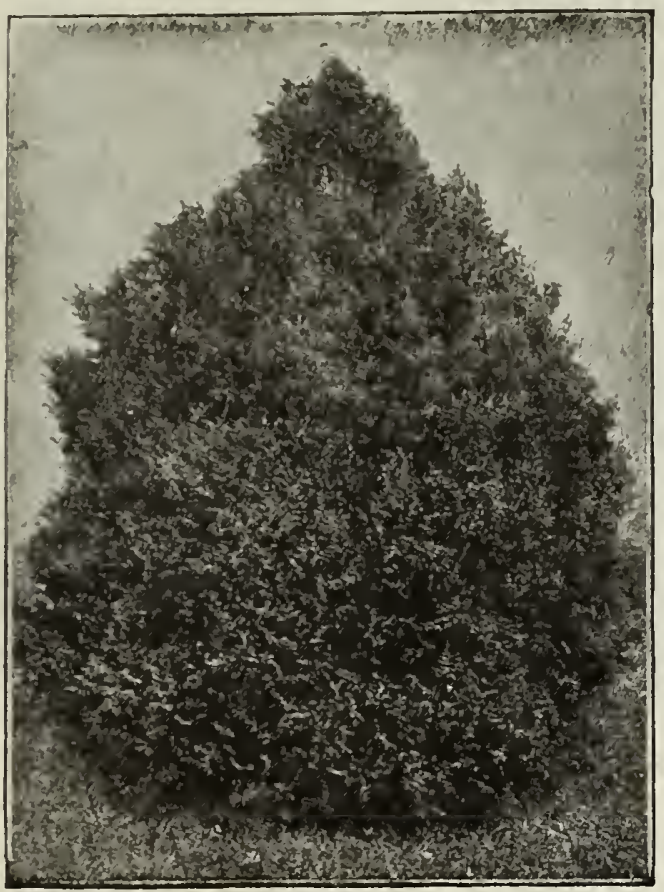

Retínosporas Plumosa
(CHAMAECYPARIS, OR DWARF CYPRESS)

As miniature trees for grouping in the small city or suburban garden these are umequaled They liave softer and more feathery outínes than other dwarf conifers Their colors, too, are so delicately lríglt and varied a to make contrast of the different sorts in bcdding tastefu rather than violent. They have exquisite shadings of white, green and yellow that are merciy intensified by shearing and a constant source of pleasure. Close shearing gives the foliage a moss like effect: when left to grow more freely, it is featlicry fronded and haif drooping. The demand for Retinosporas indicates that tlicy are by far the most satisfactory small evergreens for ail purposes.

VEITCH'S SILVER CYPRESS. (Retinospora Squar rosa.) Exceptionally dainty and distinct in both form and color of foliage, which shows three beautifully blended shades in spring. The older foliage is a soft moss-green, brichtening to silvel toward the feathery spirals of young growth which are aimost white unsurpassed by any evergreen yet sent us from Japan It is bright and happy in expression, sparkling with silvery rolor, dense, graceful, elegant Price, 1 foot, 25 cents each; 2 feet, 75 cents each.

PLUMOSA. (Plume-iike Cypress, A small, dense tree of conical outline. Folíage bright green, disposed in numerous feathery branehes. One of the most popular varieties. Price, 1 foot, 25 cents each; 2 feet, 75 cents each.

PLUMOSA AUREA. (Golden-plumed Cypress,) Ter minal growths and foliage bright golden yellow. De eidedly the best of the variegated forms. Price, 1 foot 25 cents each; 2 feet, 75 cents each.

GOLDEN PEA-FRUITED CYPRESS. (Anrea) O even brighter color than the former, looking, in a winter landscape, like a splash of sunshine on a dull day, More open and upright in outline than Veiteh's, with pendulous branchlets having all the delicacy of seaweed in a full, rich golden hue. In demand for all sorts of deeorative work in house and garden. Price, 1 foot, 25 cents each. 2 feet, 75 cents each.

\section{GREEN AND GOLDEN ARBOR VITAES}

Huge trees and hedges of Box and Arbor Vitae sheltered the old time gardens-nothing helps more in creating again their sheltered restfulness, The compact growth and lively green color of the taller-growing sorts, together with their patience under all sorts of shearing and training, give them special ralue for hedging and formal uses, Some of the dwarfest and hardiest small shrubsreal iandscape buttons of gold and green-are found in this family, Their great usefulness for ornamental pur poses is scarcely less to be considered than their value as hedges

CHINESE GOLDEN. (Bíota Aurea) Really a golden bail results from the planting of a good speeimen of this charming evergreen, which is of dwari and compact habit, and of a rich yellow tone. It is fine, not only when planted on the lawn, but in boxes or tubs, either in or outdoors, While of frec growth, it nerer reaches a great heicht, kceping well under fire feet Price, to 1 feet grade, 40 cents each; $1 \frac{1 / 2}{2}$ to 2 feet grade, 75 cents each.

BIOTA AUREA NANA. (Dwarf Golden.) A new, attractive variety. Very popular, Of rather dwarf habit. with exceedingiy compact, weil rounded heads; beautiful golden-tipped foliage, A perfect gem for garden or grounds where trees of only shrub-like dimensions are wanted Very desirable for planting in pots and tubs for porch, office or house decoration. Price, 1 to $1 \frac{1 / 2}{2}$ feet grade, 40 cents each; $11 / 2$ to 2 feet grade, 75 cents each.

BIOTA ROSEDALE. (Steel Blue.) A handsome va riety originated in Southern Texas. Tery compact growth, syminetrical. rounded head, Foliage fine and feathery, of dark, bluish-ereen cast, making it unique and dis tinctive in appearance. Rapid growth while young. Makes a most attractive border for roadway or yard. If only a few Arbor Vitaes are to be ordered, include some of these They will surely pleasc. Price, 1 to $1 \frac{1}{2}$ feet grade, 40 cents each; $1 \frac{1}{2}$ to 2 feet grade, 75 cents each.

BIOTA PYRAMIDAL. (Pyramidal Golden Arbor Vítae.) Erect, syinmetrical growth, close and compact. Grow to $n$ considerable height. Makes most pleasing effect. Price, 1 to $1 \frac{1 / 2}{2}$ feet grade, 40 cents each; $1 \frac{1 / 2}{2}$ to 2 feet grade, 75 cents each.

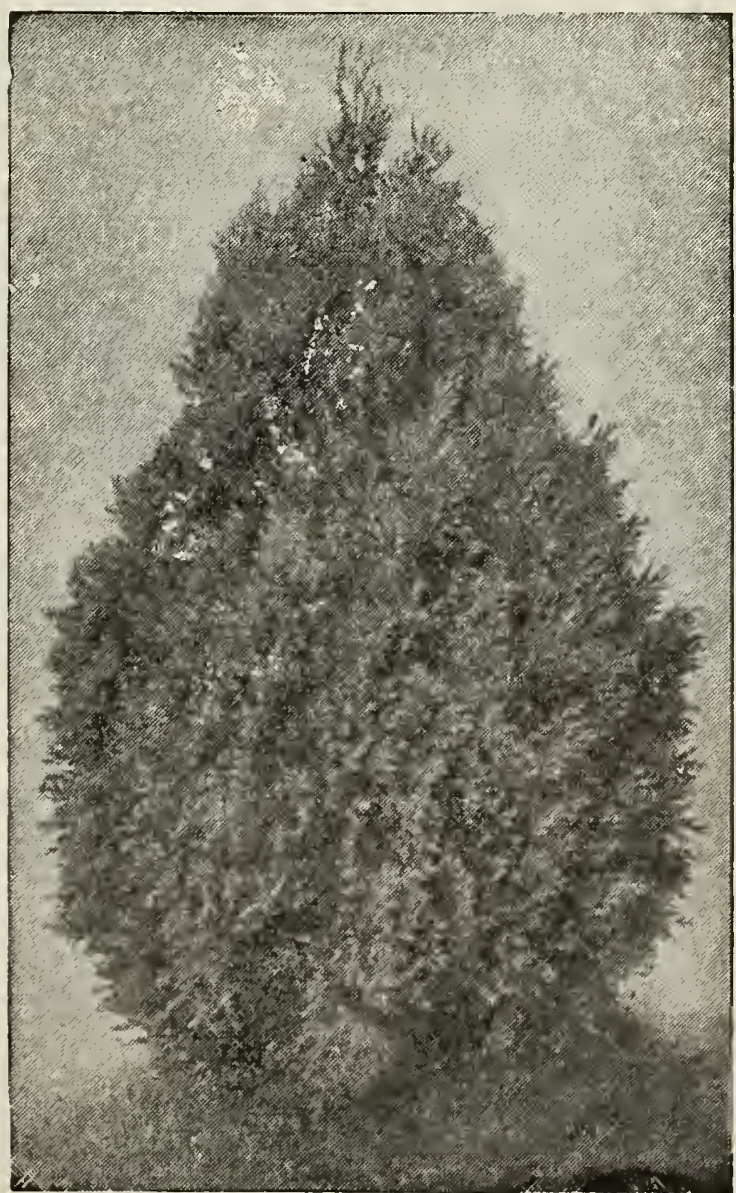

Rosedale Arbor Vítae 


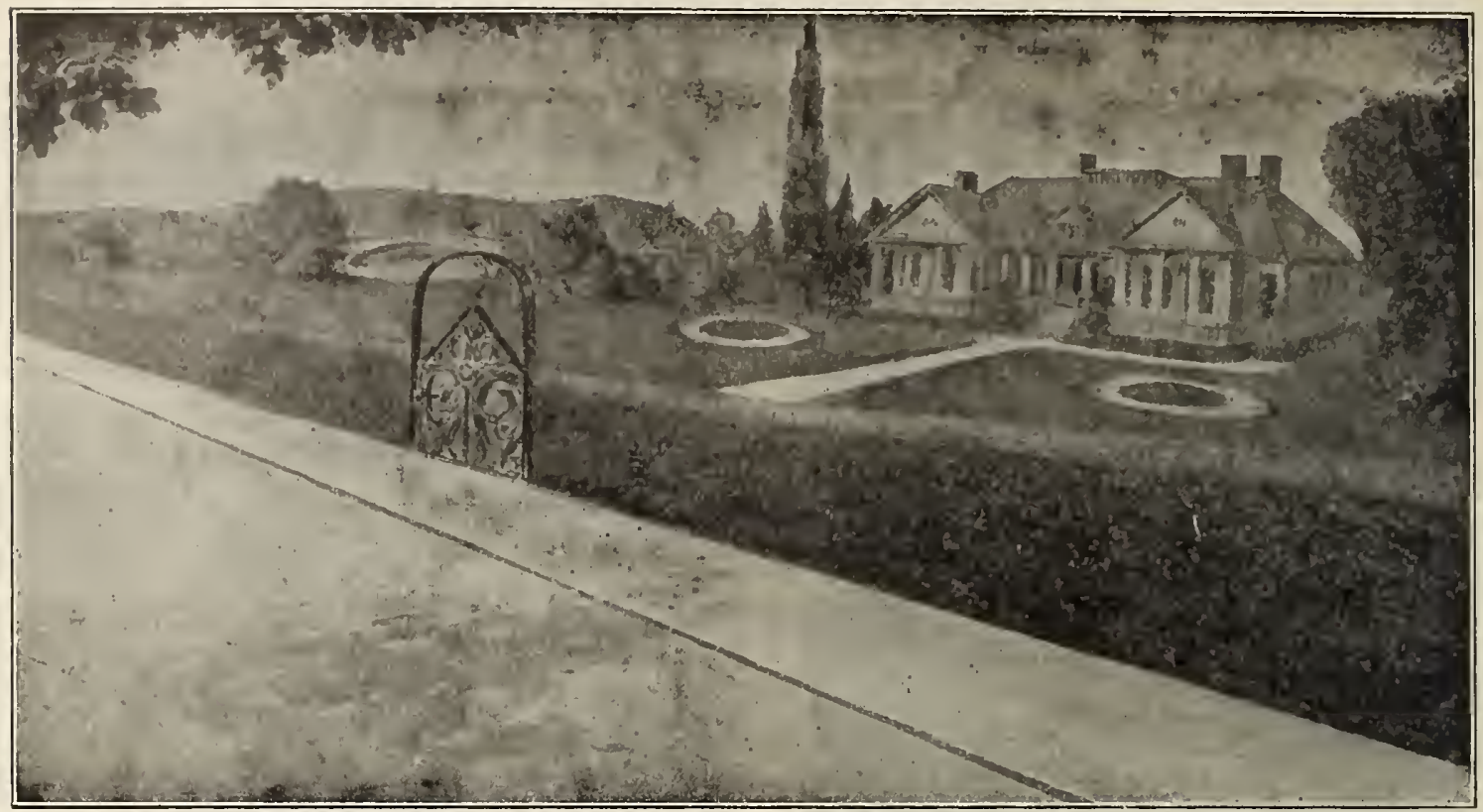

A HEDGE OF CALIFORNIA PRIVET

\section{CALIFORNIA PRIVET THEGREAT Mant}

Conceded to be the best plant for hedging purposes. Remarkable for tbe beauty of its evergreen foliage and stroug. regular, symmetrical growtb. The foliage is dark green, very glossy and wax-like; hardy everywhere. Remove the un sightly fence and increase the value of your property hy planting a California Privet bedge. Does well in all situations and under all conditions.

Privet can be pruned at any time, and tbe more tbis is done tbe better it will look and thicker it will grow. Insects never attack it, and it does not grow dull, but holds its beautiful green foliage througbout the season. We have a fine lot of good strong, well rooted plants, well branched, to offer. They sbould not be compared to tbe tall spindling tbings often offered.

Price, first size, fifteen to twenty-four inches, 10 cents each; six for 50 cents; $\$ 4.50$ per hundred, by express or freight. Second size, two or three feet, 15 cents each; five for 50 cents; $\$ 1.00$ per dozen; $\$ 6.00$ per hundred, by express or freight. Orders for fifty filled at one hundred rates.

\section{NEW GOLDEN PRIVET}

A most ornamental bedge or pot plant. It is like the common Privet except most of the leaves are golden yellow, or variegated green and yellow. It is bardy and robust and as its leaves remain on all winter it is doubly useful and gives fine color effects. As a pot plant, or specimen for the lawn, it is also fine and surpasses all other golden leaved plants. It is certainly a beauty and will greatly please everyone. Price, 20 cents each; 3 for 50 cents; 10 for $\$ 1.50$.

\section{TAMARIX}

Fine feathered foliage like that of the Juniper; valuable in sand or soil where most shrubs will not do well.

AFRICANE. Handsome featbery foliage; uprigbt growth; small pink flowers on long spikes. Price, 15 cents each.

\section{IRISH JUNIPER}

A columnar tree reacbing a beigbt of fifteen or twenty feet. Leaves bearing two white lines above, bright green beneath, thickly clothing the closely ascending branches which droop perreptibly at the tips. Quite hardy and of great value in formal gardens. Price, 1 foot, 25 cents; 2 feet, 50 cents each; 3 feet, $\$ 1.00$ each.

\section{CUTTING DOWN A PRIVET HEDGE}

There is many a hedge of Privet to be seen too bare at the base, caused by improper trent ment wben first planted. The plants were not cut back sufficiently at that time. In some case the owners have declared tbat the object was, when planting, to get a screen and get it quickly, not to make a hedge, just as trees or shrubs are often seen planted for the same purpose. In cases of this kind there is no need to bave a tbick, uniform mass of twigs and leaves from the ground to tbe topmost growtb.

But when a hedge is wanted then we do look for uniformity, and the bareness at the base must be remedied. We bave seen cases where sucb hed es have been cut down too near tlie ground to get a good growth from the base, the cutting back being performed in early winter. It is much better to leave the work until spring. Sometimes tbis Privet will be a trifle injures in severe winters, and when cut back in autumn there would be more liklihood of harm in such weather than if unpruned, so it is the better plan to let all the growtb stand as it is, cutting it back in early spring.

No matter how tall or how large the bedge, it will sprout afresb and give satisfaction if cut back, even to the ground. But a good way is to cut it down to four inches. The new shoots are then so close to the ground that it is one's own fault if a model hedge does not result. As soon as the new shoots are six inches in length, the shapening of the hedge should commence, by pincbing off their points until the whole is a bushy, uniform mass. When this is accom. plished, the future forming of the hedge is no trouble; the whole is a matter of good judgment

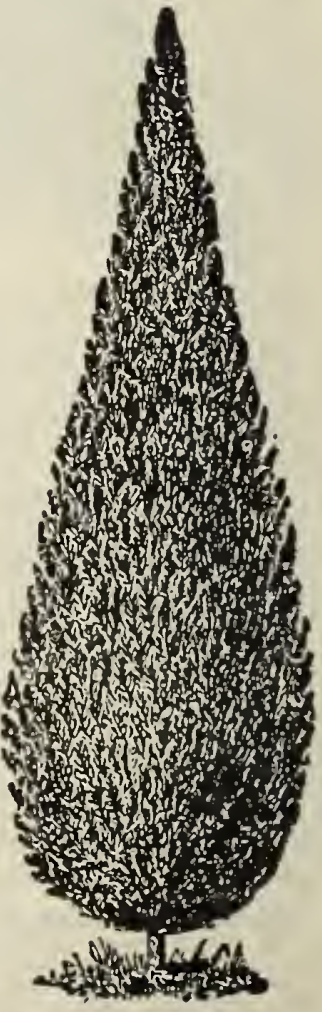

Irish Juniper 


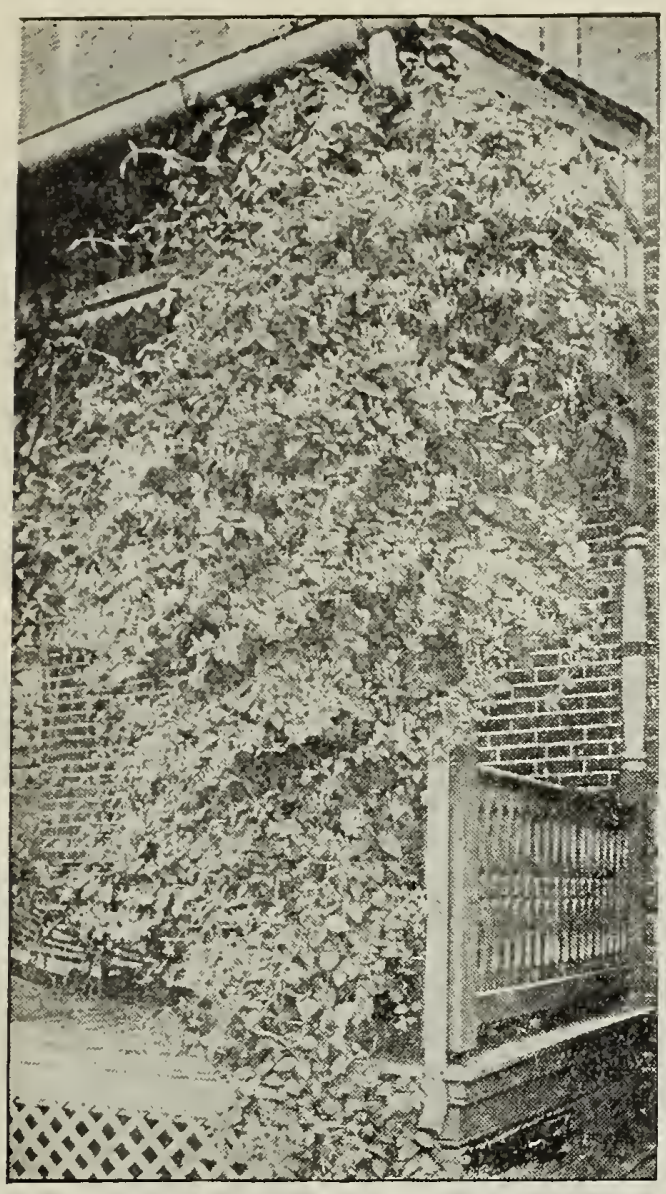

Honeysuckle

\section{BOSTON IVY}

A beautiful, hardy climbing plant, of Japanese origin. This is one of the finest climbers we know of for corering walls, as it clings firmly to the smoothest surface covering it smoothly with overlapping leaves, which form a perfect mass of foliage. mass of foliage. The color is a fresh, deep green in summer, changing to the brightest shade of crimson and
yellow in autumn. It is quite hardy, and becomes more popular every year. Price, strong plants, 15 certs each; four for 50 cents.

\section{CLIMBING EUONYMUS}

\section{(Euonymus Seiboldi.)}

By some authorities this is considered a better evergreen vine than even the English Iry. For the first few years it elings closely to walls in a mat of small glossy leares, but when established it becomes more shrubby in character, throws out strong branches and has broad, glossy leaves similar to those of the Japan Euonymus shrub. Fertile plants have many pink fruits with showy scarlet arils amid these handsome leaves, and their effect is fine beyond description. It will grow 20 or more feet high. price, strong plants, 25 cents each; $\$ 2.50$ per dozen.
Prond dill

\section{ENGLISH IVY}

The grand high-climbing old English vine, with dark green leaves of classical outline and beauty. One of the most beautiful vines for walls, pillars, tree trunks, ground covers, etc., that can be used. The ivy of literature and nld European ruins. Price, strong plants, 15 cents each: $\$ 1.50$ per dozen; extra strong plants, 25 cents each; $\$ 2.50$ per dozen.

\section{CLEMATIS}

JACKMANI. The well known type, with flowers of rich, deep royal purple. Price, 50 cents each.

HENRYI. Pure White. Price, 50 cents each.

MAD. ED. ANDRE. Crimson red. Price, 50 cents ach.

CLEMATIS PANICULATA. Bears great clusters of pure white deliciously scented flowers. Price, 15 cents

\section{HARDY VINES}

We are all beginning to realize what wonderful grace and beauty well-placed vines may add to home and garden - that besides porch and window draperies and soft wallcovers, vines will quickly make for us enchanting pergolas and shady arbors that are more enjoyable in summer than conventional apartments.

\section{Honeysuckles}

\section{OLD AND NEW.}

GOLDEN JAPANESE. Flowers creamy white, fragrant, scarcely more beautiful than the golden netted leaves. Price, strong plants, 15 cents each; $\$ 1.50$ per dozen.

HALL'S. Even in cold climates this vine holds its leaves until January; in the South it is evergreen. It is the freest anowing; and blooming it is erert showing fragrant flowers of buf and white from flowers of buficand white from May until December in our
latitude. Price, strong plants, 15 cents each; $\$ 1.50$ per latitude.
dozen.

SCARLET TRUMPET. This most beautiful and brilliant of all Honeysuckles is also the hardiest and most vigorous. The stems often twine about second story windows, wreathing them in early spring with large, inodorous clus. ters of long, tubular scarlet flowers. The foliage is bluish green, the berries scarlet. Also called Coral Honeysuckle. Price, strong plants, 15 cents each; $\$ 1.50$ per dozen.

\section{JASMINE}

YELLOW. (Jasminum Nudifiorum.) This is entirely evergreen in the South and much farther north than is commonly supposed. The stems, too, are a dark shining green and during mild winter months, regardless of the calend ar, its sunshiny vellow flowers appear thickly along calendar, its sunshiny yeilow friers the branches. Each petiole carries three small leaves similar, to those of the "Boxwood, "Climbing Evergreen Clostrong plants, 15 cents each; $\$ 1.50$ per dozen.

JASMINE PRIMULINUM. A new species; foliage small and pretty; flowers yellow, as large as a half-dollar, opening flat, scented, blooming in long sprays in winter, and keeping when cut, in water, indefinitely. An exceedingly valuable small shrub. Price, 25 cents each.

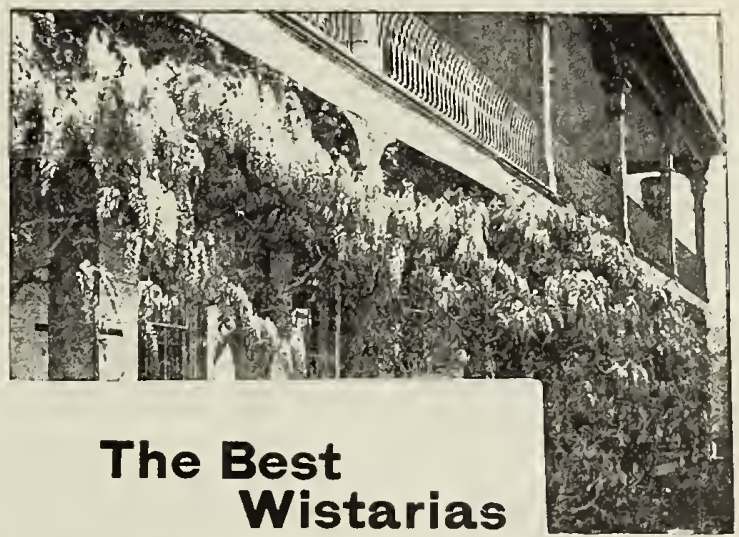

CHINESE BLUE. There is no vine more decorative in its effect than the Wistaria. Its long, twining branches bearing great sprays of compound foliage, climbing graceful, artistic curves, even to the top of a tall building, while its charming racemes of dainty light purple or blue flowers in May sway with every passing bree\%. For porch decoration without too much shade they have no superior. Price, 20 and 35 cents each.

CHINESE WHITE. The white variety, in all respects same as purple, except in color. Price, 40 cents each.

\section{PLANTS AND SEEDS}

Can now be sent by Parcel Post in packages up to 11 pounds in weight to any point in the United States at 8 cents per pound. We prepay packages up to four (4) pounds, but on larger packages charges must be paid by the purchaser, unless you take advantage of our 10 per cent delivery offer. 


\section{Hardy Deciduous Shrubs}

The various uses for shrubs in every scheme of planting lave multiplied fast. More than with any other class of plants is the nurserman taxed to meet the demand for them in quantity and rariety. With shrubs alone a garden can now be kept gav all the season if a good selection is makle. Besides the important uses of providing flowers for all the spring and summer months, for specimens and for grouping, shrubs are now used for bedding, sereens, hedges, grading steep banks, covering house foundations, rounding angular house or drive lines, covering bare spots where grass will not grow, filling in hollows on rough hillsides, etc. The plants wa send out are all strong and vigorous. WEe pay particular attention to having theu true to name, correctly labeled anl packed in the lyest possible manner.

A WORD ABOUT PRUNING AND PLANTING. Slurubs need not be prumed at all unless it be to shorten them if they grow too straggly; if they nust be pruned, the best time to do it is just after they luave blonmed, but individuality of habit and foirage should be preserved. The pruning of a'l shrubs into one shape, or into different formal shapes, gives a monotonous effect and shows a lack of appreciation fir natural beauty.

\section{Double Altheas}

(Rose of Sharon.)

They grow neat and compact, and uake nice shapely trees, four to six feet high. They bloom in Alugust and September, when other flowers are scarce, and are literally covered with large, perfectly double flowers, like roses, of differ

JOAN d'ARC. This is entirely new, and the finest Double white Althea ever introduced. grows regular and compact, and is literally covered with lar re, perfectly compact, and is literally covered with large,
double pure white flowers, three inches across.

BANNER. Large double flowers; clear bright pink.

LUCY. Large, double rose red flowers; rery handsome. BUIST'S VARIEGATED LEAVED. Beautif $u l$; leaves green, broadly margined silver white; flowers double.

DOUBLE PURPLE. Double flowers; reddish purple.

TOTUS ALBUS. Finest single pure white.

\section{MAGNOLIA PURPUREA CHINESE PURPLE MAGNOLIA}

The Magnolias as a class are valuable trees. Their broad leaves, large showy flowers, and perfect hardines make them desiralle in many ways. This variety is on of the best and most widely known. It is shrubbery and branching, while young, but later becomes a fair-sized tree. Before the leaves appear, it bears large cup-shaped flower five inches in diameter; purple with a deep pink center. Price, 40 cents each.

\section{DEUTZIAS}

Price, 20 cents each.

PRIDE OF ROCHESTER. Grows strong and upright, four to six feet high; flowers rery double and full; pure white, tinged with blush.

CRENATA. Single. Pure white flowers,

FLORA PLENA ROSA. Flowers double white tinged with pink, in racemes four or five inches long; one of our finest hardy shrubs.

LEMOINII COMPACTA. Much dwarfer and more bushy than the D. Lemoinii. Flowers pure white, the thryses numerous and closely set.

GRACILIS. A cliarning species of dwarf habit; flowers pure white, very graceful and pretty. A valuable plant for winter blooming.

GRACILIS ROSEA. New, A grand inprorement on the above. with much larger flower, which is faintly the above, with
tinged witl pink.

\section{DEUTZIA LEMOINII}

Price, 20 cents each.

Without doubt one of the best hardy slurubs offered in many years. It is a hybrid between D. Gracilis and D Paryifora and has the advantage orer the former of paving flowers nearly three times as large which are having flowers nearly three times as large. Which are iwenty to thirty flowers each, and are of purest white, which open out rery full.

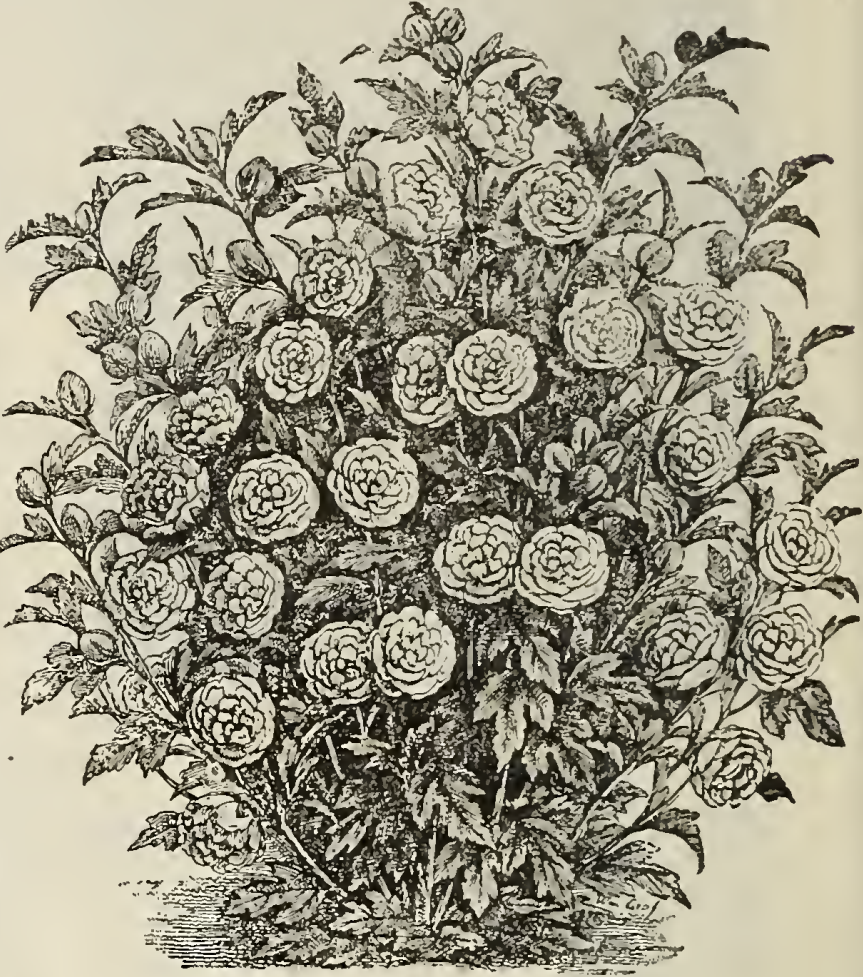

New Double Pure White Althea, Joan d'Arc

\section{FORSYTHIA}

OR GOLDEN BELLS

This is one of the urost useful shrubs for the permanent decoration of buildings. It can be easily traiued over a wall, fence or tree trunk. The flowers are bell shaped, of a clear yellow, and there are no green leares. It is the earliest shrub' to bloom. It will thrive under trees, at the north side of houses, or between honses where almost anything else will perish, or in open sunlight. Price, nice strong plants, 25 cents each.

\section{CALYCANTHUS}

(Sweet Scented Shrub.) Flowers chocolate color, rery double and deliciously fragrant; remains in bloom for a long time; very desirable. Price, 25 cents each.

\section{TIME TO PLANT PRIVET}

For years you have plauned to set a hedge of California Privet, sometime. Don't put it off any longer. You call buy the choicest stock to a splendid advantage right now. To be sure of getting what you want, ORDER FROMI A CALIFORNIA PRIVET SPECIALIST. 


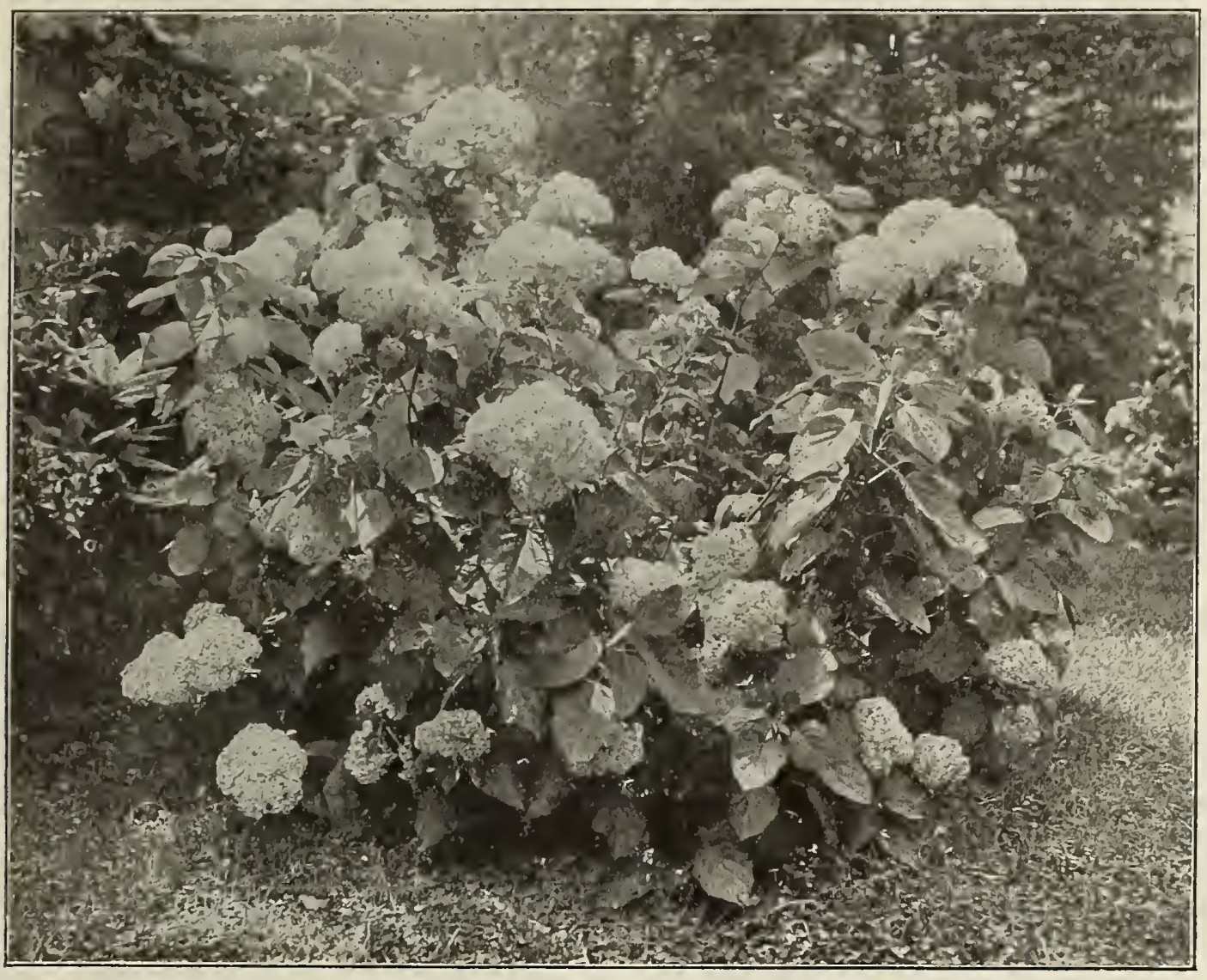

FROM A PHOTO OF A THREE.TFAR OLD PLANT TAKEN JUNE 18th.

\section{AMERICAN EVERBLOOMING}

\section{HYDRANGEA ARBORESCENS GRANDIFLORA}

This is beliered to be the most beautiful hardy flower ing slirub introduced during the last fifty years. It was found growing wild on the rock hills of Western Pennsyl vania several years ago. The old and well known $\mathrm{Hy}$. drangea Paniculata Grandiflora, which, up the the intro. duction of the new form, has been one of the most popular fiowering shrubs, blooms only in this latitude during August, while the new sort blooms continuously from early Jume until the end of the growing season. The size of the flower is one of the striking features of this shrub. Blooms twelre inches across are frequent in young plant, while the arerage size on mature plants is usually six inclies or more. The color of the flower is a pure, dazzling white, without the creamy and later pink tints of the old H. Paniculata Grandiflora. The length of time this white. ness is retained depends somewhat on local conditions, but usually from four to five weeks, when the flowers begin to change gradually to a light green color, and by October the flowers and foliage are of a similar shade of green.

The flowers, when cut, possess remarkable keeping qualities, remaining in good form and color many days. This feature renders it specially valuable for florists' use.

This Hydrangen is also one of the very best shrubs for forcing under glass, equal to any other used for that purpose: easily brought into bloom for Easter sales, as well as for later events.

This Hydrangea gives every promise of becoming even more popular than the well known H. Paniculata Grandi. flora. as it does not have the coarseness and stiffness of that variety: it is refined in tone and effect, and, with its abundant and handsome foliage, it lends itself readily to landscape effects. It is a comely, handsome shrub at all tiues. Price, nice young plants, strong and healthy, 25 cents each, or five for $\$ 1.00$.

\section{HYDRANGEA PANICULATA GRANDIFLORA}

THE PLUMED HYDRANGEA

This popular hardy shrub needs no description from us It is easy of cultivation, growing rapidly, and produces showy flowers in late July and early August, at a time when other shrubbery bloom is scarce. The bloom lasts into the autumn, when it changes from white to shades of pink. To produce tle best effects, it should be planted in masses or with a background of other shrubbers. When mrown in beds or groups, they should be planted about two frown apart in very rich soil, which should be liberally feet apart in very rich soil, which should be liberally
enriched annually with some old, well-decayed fertilizer. Early in the spring, before the shrubs begin to grow, cut them back so as to leave only two or three inches of new growth. Price, 25 cents each; five for $\$ 1.00$.

\section{EXOCHORDIA GRANDIFLORA}

A vigorous growing shrub, forming a neat, compact bush ten to twelve feet high. The flowers are borne in slender racemes of eight to ten florets each. It is perfectly liardy; racemes of eight to ten florets each. It is
flowers pure white. Price, 25 cents each.

\section{CRAPE MYRTLE}

(Lagerstroemia)

INDICA. Very beautiful shrub. A profuse and con. tinuous bloomer; flowers bright rosy pink, with curiously crimped petals. Price, 25 cents each.

NEW CRIMSON. Vivid crimson. Price, 25 cents each

PURPUREA. Of a peculiar purplish erimson color. Price, 25 cents each.

WHITE. Flowers purest white and beautiful; of recent introduction and a general favorite where known; of rigorous and symmetrical growth. Price, 25 cents each. 


\section{COMMON SNOWBALL}

A well known shrub, attaining the height of 8 or 10 feet; produces it snowy white flowers in large balls or
masses in April. Price, 25 cents each.

\section{WEIGELIA}

ROSEA NANA VARIEGATA. One of ROSEA TATA VARIEGATA. Slurubs. Leaves beautifully margined creamy white: flow ers pink. Price, 25 cents each.

CANDIDA. Very fine light green foliage and handsome pure snow white 25 cents each.

EVA RATHKE. We certainly have a rand acquisition in this variety. a remarkable free bloomer and entirely dis. tinct color being a rich reddish purple. Price, 25 cents each.

\section{POMEGRANATE}

Price, double flowering, 15 cents each; truit bearing, 15 cents each.

\section{LILAC}

NEW DOUBLE NAMED LILACS. We offer only large sized plants, distinct varieties. Price, 40 cents each; ten for $\$ 3.00$.

PURPLE. Grand new variety; flowers deep purple; fragrant; blooms second year. Price, 25 cents each.

WHITE. Rare and beautiful. Very sweet. Price, 25 cents each.

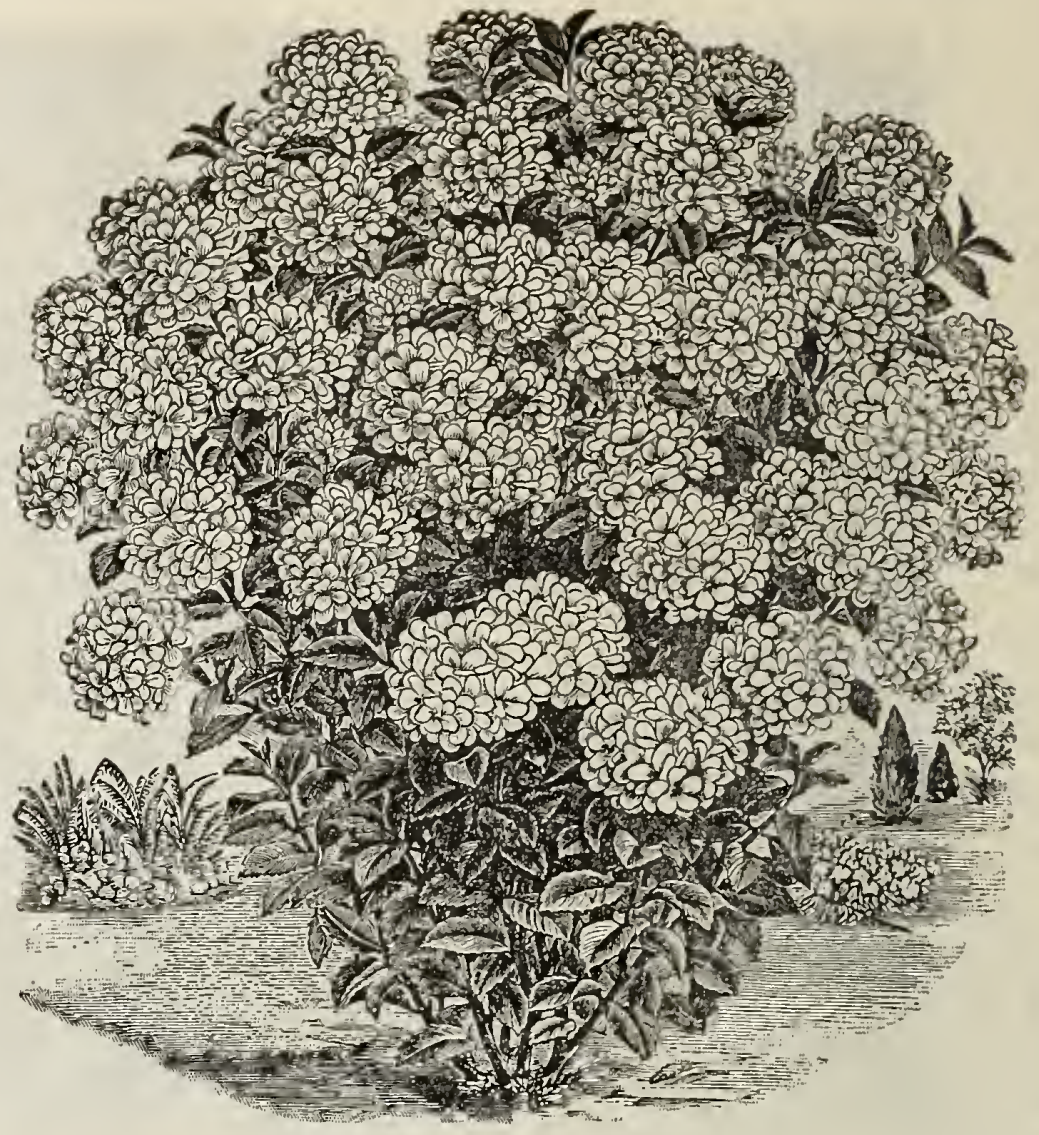

Snowball

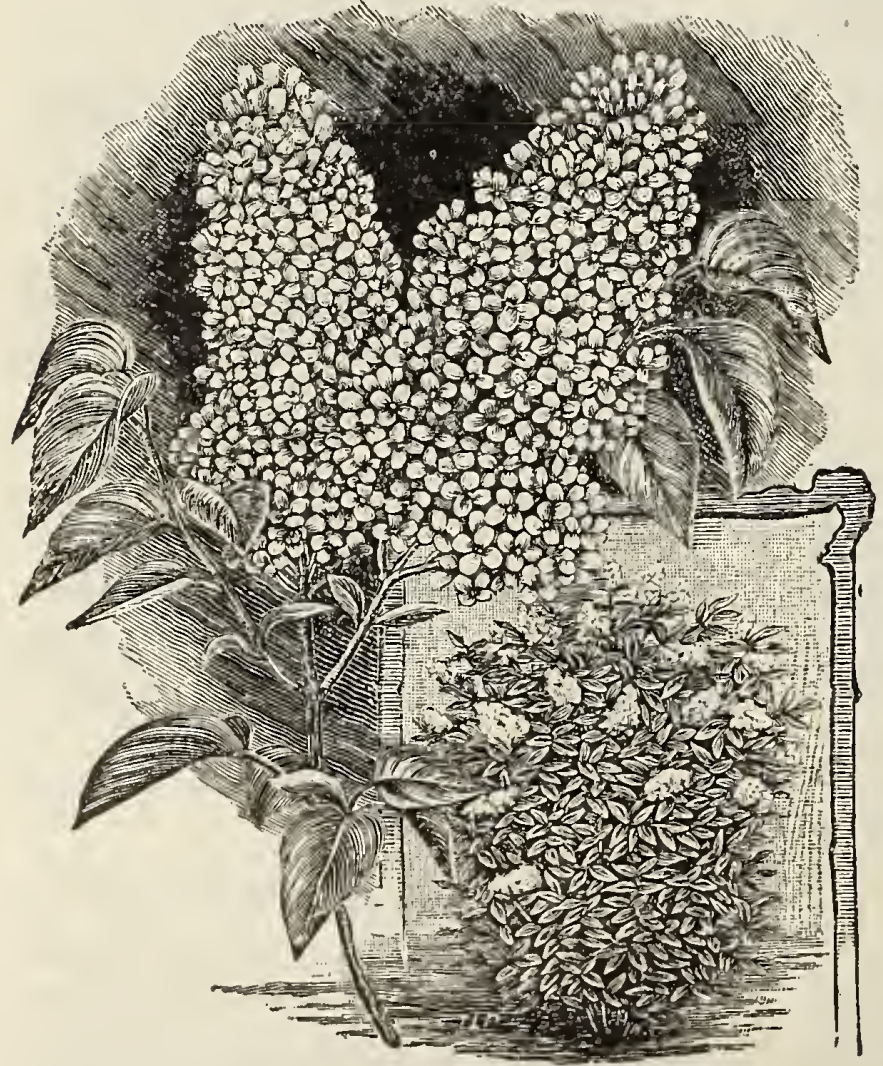

\section{SPIREA ANTHONY WATERER}

A fine hardy perpetual blooming shrub, particularly desirable for the door yard and lawn, or wherever fine, hardy flowering shrubs are wanted. IIakes nice round bushes only 15 to 18 inches high. begins to bloom almost as soon as planted continuing all summer and fall rich rosy red flowers. If lifted and taken indoors will bloom all winter. Strong plants that will bloom this season, 15 cents each; two for 25 cents; eight for $\$ 1.00$. Two year size, 20 cents each; six for $\$ 1.00$; $\$ 1.75$ per dozen, by express.

\section{SPIREA VAN HOUTTEI}

The grandest of all the white Spireas; it is a beautiful ornament for the lawn at any season, but when in flower it is a complete fountain of white bloom, the foliage hardly showing. Clusters of twenty to thirty flat white florets make up the raceme, and are set close along the drooping stems. Price, 25 cents each; five for $\$ 1.00$.

\section{SPIREA COLOSSA ALBA}

Pure white flowered, dwarf growing variets; very good for edging beds of taller growing shrubs. Price, 25 cents each.

\section{NEW JAPANESE BLUE SPIREA}

Irakes neat compact bushes, eighteen inches to two feet high: begins to bloom in August and continues loaded with lovely sky blue flowers till frozen up or covered with snow; sweet and much sought after by bees; hardy here. Strong plants to bloom this season. Price, 15 cents each. 


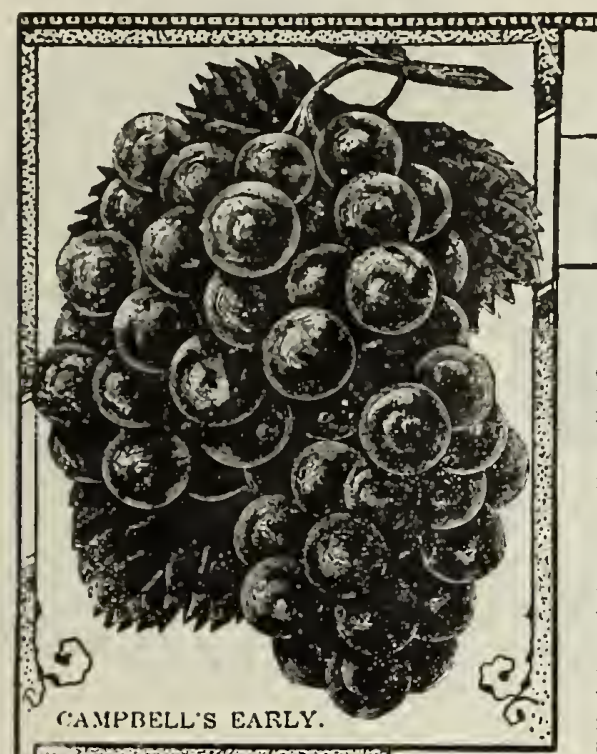

\section{"WONDER' \\ BRAPE COLLETTION.}

There is scarcely a yard so small, either in country or city, that room for one to a dozen or more grape vines cannot be found. They do admirably trained up by the side of any buildinc, or along the garden fences, occupying but little room and furnisling an abundance of the healthiest of frvits mellow, and plant the vines somewhat deeper than they stood in mellow, and plant the vines somewhat deeper than they stood in
the nursery. Plant about eight feet apart, by the fence or huilding. For vineyard, make rows eight fect apart, six to ten feet in rows.

\section{POSITIVELY THE BEST COLLECTION EVER OFFERED}

We have selected what our grower considers the best twelve varieties grown for general use, including some of the newer ligh priced varieties. The collection contains six Black, three White and three Red varieties, as follows:

WYOMING. Vine very hardy, healthy and robust, with thick, leathery foliage; color of berry similar to Delaware, but brighter, being one of the most beautiful of the amber or red grapes, and in size nearly double that of the Delaware; fiesh tender, juicy,
sweet, with a strong native aroma.

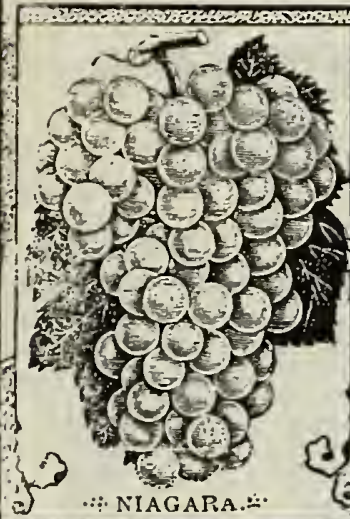

CONCORD. Too well known to need description. We include it in the collection because it is one of the best and should be in every garden.

DIAMOND. Like the Concord in vigor of growth, foliage and hardiness, but ripens two weeks earlier. Color, delicate greenish white, tinged with yellow; size same as Concord and quality of the very highest, being very juicy and sweet.

DELAWARE. Bunch small, compact and shouldered; berries small; skin thin, light red; very juicy, sweet and delicious. Unsurpassed in quality.

BRIGHTON One of the best red Grapes for table use Color, red or amber; bunch' large, well formed; berries above medium in size. Most excellent in flavor and quality. Early.

MOORE'S EARLY. Bunch large; berry large, round, black, with heavy blue bloom; very tender and sweet. Quite early. Very hardy, vigorous and productive.

NIAGARA. A grand Grape Very hardy and vigorous in habit; bunch large and compact. Berry large, greenish white changing to pale yellow. Quality excellent, melting and sweet. One of the best.

WORDEN. A splendid Grape of Concord type, but earlier, larger in bunch and berry, and of decidedly better quality; vine hardier and in every way as healthy. Exceedingly fine.

MARTHA. Bunches and berries of medium size; greenish white, with a

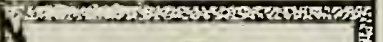
thin bloom; flesh tender, witb very little pulp; juicy, sweet and rich; hardy and productive. Ripens with Concord.

CATAWBA. Berries large, round; when fully ripe of a dark copper color, with a sweet, rich, musky flavor. Requires a long season to arrive at full maturity.

EMPIRE STATE. Very large bunch; medium size berries, juicy, rich, sweet and sprightly; continues for a long time fit to use.

IVES. Bunch medium to large, compact, often shouldered; berries medium, slightly oblong, of a dark purple color.

Price, two year old vines, 15 cents each; twelve vines for $\$ 1.50$.

WE WILL FORWARD THE ENTIRE COLIEC TION OF TWELVE STRONG VINES TO ANY ADDRESS FOR ONLY $\$ 1.50$.

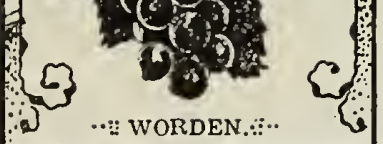
E.

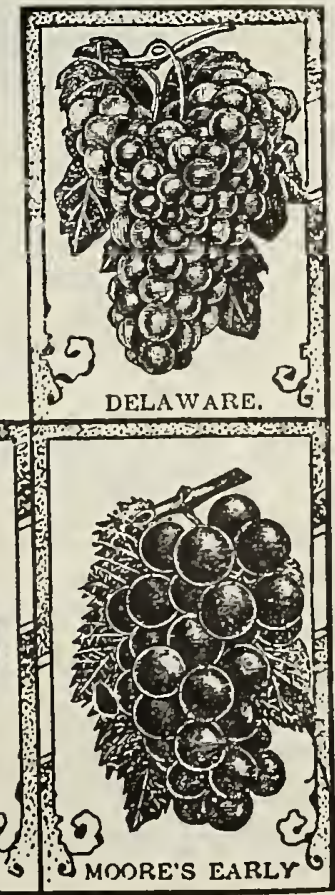




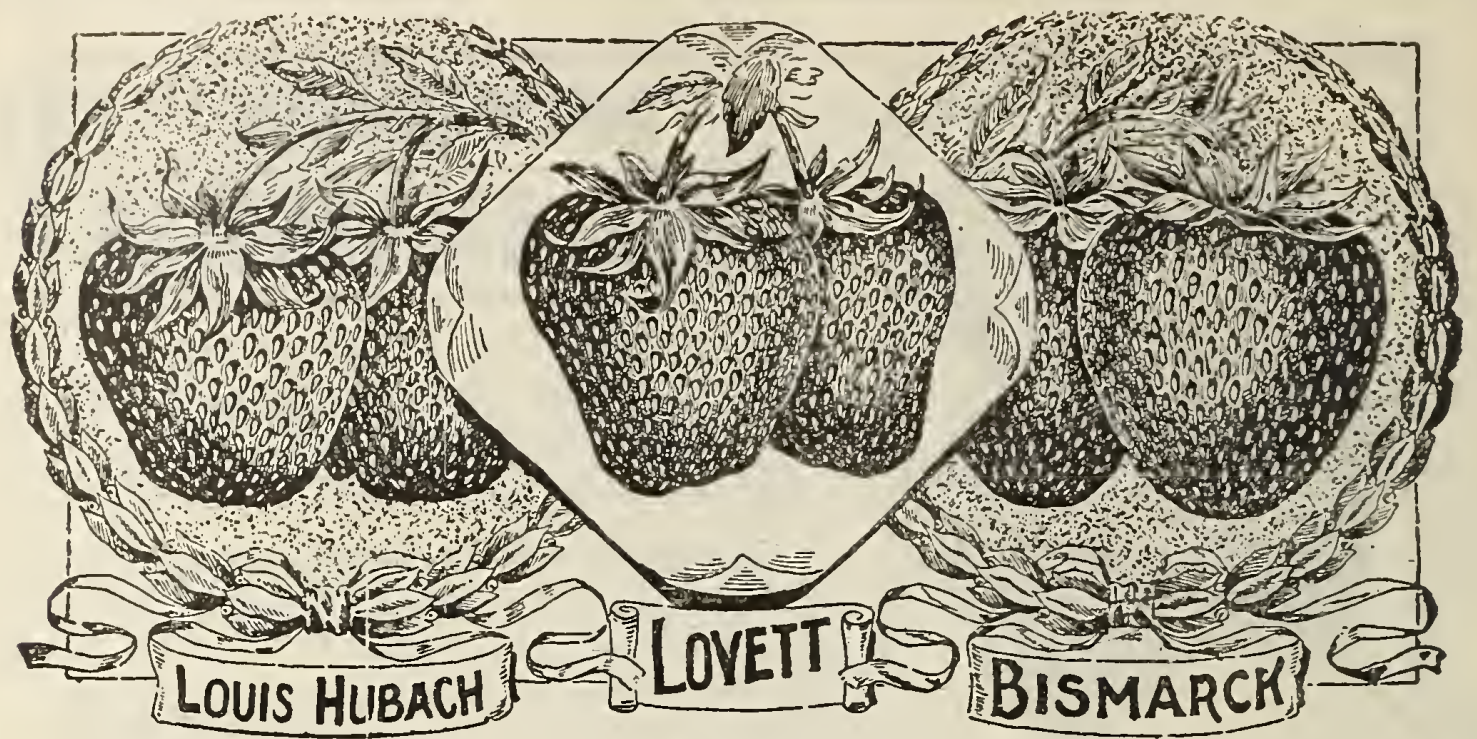

\section{Selected Strawberries}

NOTE.-When setting out Strawberry plants be careful not to let the roots get dry. It is a good plan to dip the roots in water, taking care not to wet the crowns, and then "heel in' in moist, shady ground until you are ready to plant. Press the earth down firmly on the roots, so as to exclude the air and hot, drying winds. This is important.

Kinds marked (Per.) are perfect flowering. Kind marked (Imp.) is imperfect flowering and needs a (Per.) kind planted near to make it productive.

Price, except noted, 25 cents per dozen; $\$ 1.00$ per 100 , postpaid; or by express, 75 cents per $100 ; \$ 5.00$ per 1,000 . Not less than 25 of a sort at 100 rate, or 500 at 1,000 rate. (Ready at planting time.)

AROMA. (S.) Large; glossy red; productive and profitable; midseason to late.

BRANDTWINE. (Per.) This variety is well known. and has been quite thoroughly tested. It is now regarded as one of the best late sorts known.

BISMARCK. (Per.) To those familiar with the Bubach, nothing further can be said, since Bubach has been a favorite berry, and more plants have been planted than any other. We have in Bismarck an extraordinary large berry, glossy, fine color, good shape and good quality, with vigorous plants full of vitality.

BLAINE. (Per.) In this variety we have a variety which is much more productive than Gandy, of which it is a seedling; is very much like the Gandy in plant growth, and a more thrifty grower. Berries large and more productive.

BRILLIANT. (Imp.) A new and promising variety; midseason in ripening; berries even shaped and productive; plant a good, healthy grower.

CLYDE. (Per.) This is perhaps the most popular New Strawberry equer introduced seeming to do equally well in all parts of the country. The clyde ripens early, is large as Bubach and much firmer.

CLARK'S EARLY IDAHO. (S.) A variety well adapted ChA extreme South; season medium rearly; an enormous bearer of large, round, well-shaped berries of a beautiful bright scarlet color.

COOPER. New. A seedling of Pan American; not a fall bearing variety, erect healthy foliage. A prolific bearer, of good size and fine flaror; color, red clear through. Season medium to late; a good shipper.

EXCELSIOR. The earliest berry in existence. Good : strong grower; firm, and a good color.

EVENING STAR. (Per.) A promising midseason to ate. Berries are as large as Aroma; has the shape of Gandy, of which it is a seedling; is more productive. Plants of healthy growth, and a No. 1 variety.

FENDALL. (Pistillate.) A productive rariety, of large and delicious flaror: early and long bearing season. Plants make clean, liealthy growth.

GANDY. Its season is very late, and it is in its prime hen other sorts are gone. The fruit is large, ndsome and uniform

HOFFMAN. The handsomest of all berries. In the llurial soil of the South is a raluable extra early, firm, rilliantly colored, fancy market berry. It is too sour for
HAVILAND. A grand berry; early and immensely productive. Berry large, somewhat long and pointed in shape.

KLONDYKE. (S.) This berry has gained a greater reputation in the South than any other variety we have here. The berry is large in size and very regular shape. The color is bright red.

LOUIS BUBACH. Remarkably vigorous, and one of the best to withstand drouth; very productive. The fruit is large, dark red, somewhat rough, and will bear shipping to a distant market.

LOVETT. (Per.) It is certainly a raluable acquisition to the list of good berries. Fruit large, solid and firm; excellent for market.

LADX THOMPSON. (S.) Large, even sized: good flavor; good color; early and productive; good shipper: strong, healthy growth; one of the best.

MTCHELL'S EARLY. (Per.) As large and firm as the Crescent, and ten to twelve days earlier.

MARSHALL. (S.) Heavy foliage: vigorous growth; fruit large and showy; popular hoine berry.

NORWOOD. (S.) New. Claimed to be of larcest size. Prolific bearer and fine color; stands our hottest seasons well; healthy foliage.

NICK OHMER. Of largest size, a giant among straw. berries; robust, healthy habit; dark, glossy red fluit; firm and productive.

PARKER EARLE. (S.) Robust, strong growth; makes ut few runners: enormously productive. large liglit, glossy, scarlet berries; regular conical slape.

SENATOR DUNLAP. (Per.) Thorouglily tested and proved one of the best standard varieties wherever tried: prong hards, deep-rooted plants; a great bearer of bright, glossy red berries of first-class quality.

ST. LoUIS. (S.) In size it is larger than Lady Thempson and has produced berries of suficieut size for twelve to fill a quart. Plants are thrifty and without rust and rell rooted.

SUCCESS. (S.) A new variety of much merit; strong healthy growth; berries large; dazzling crimson; of fine flavor.

TEXAS. A medium sized, well filarored, very early berry. Good for home use.

WARFIELD. (Per.) Its size. while not of the largest is good, and it is exceedingly firm. 


\section{A New Race of Everbearing Strawberries}

PAN AMERICAN. Ever-benring Struwbery. A straw herry plant that produces a continuous rop of fine, large strawberies from midsumuncr until winter. Pick off all fruit stens uneil July; after that date allow them to llowm till early August. It fruits well on the current year's young plauts as well ns on the old ones. The first lerries ripening on the old plants while the younger plants sre in bloom. Price, 25 cents each; $\$ 2.50$ per dozen.

SUPERB. The Superis is the largest fall strawbery I lave ever seen, is mlossy, dark red, and very attractive, as well as of the finest flavor. The plants are strong, healthy growers, with long rumners which stretch orer a grcat sur. face of ground. It loes not make such large roots as Productive, but the folinge is rery strong and lienlthy. Productine, but the folinge is rery strong and lo brines The beries are lare strong point in a thll strawberry. The beries are large and attractire and, like the old Ridgeway Strawbery, look as if each berry was turned ont in a lathe. The flaror is excellent. Price, 25 cents each; $\$ 2.50$ per dozen.
KEVITT'S WONDER. Berries long, egg-shaped, with distiuct, neck-sliaped berries. The greatest strawberry of the age-nature's wonderful gift to mankind, New creation, the most distinct and individual of all American strawberries. Unlike any other, this new type has never been drenmed of before; nothing like it has ever been introduced. Price, 10 cents each; $\$ 1.00$ per dozen.

AUTUMN, The Autumn is a seedling of the Pan tuerican, and is a genuine fall-bearing berry plant. Set in the spring, with fruit stems remored, will crown up and bear fruit in August, and will continue to bear unti cold weather. It is a Pistillate, and requires Pan Auerican plauts or some other fall-bearing stanimate set with them to pollinate them. The fruit is medium size, dark red clear through, and of fine shape and quality. The plants make runners more freely than the Pan American; it is a good grower, with dark green foliage, and think it will please you. Price, 15 cents each; $\$ 1.00$ per dozen.

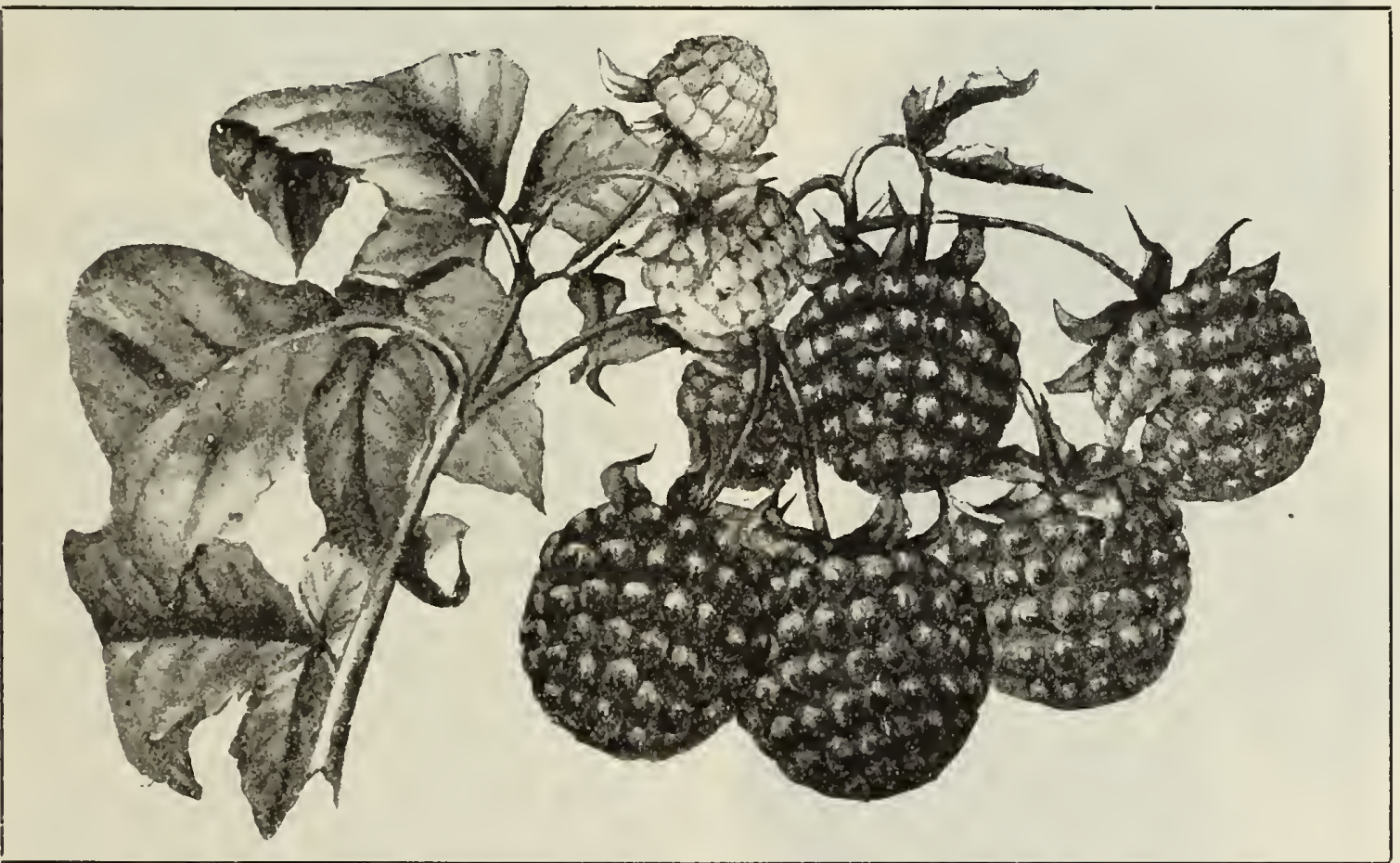

NEW CONTINUOUS FRUITING

\section{Red Raspberry St. Regis}

\section{Fruits From June to Frost}

We have pleasure in offering this fine, new, almost sensational fruit, destined, we beliere, to be the most popular ever introduced. It is the earliest of all red Raspberries, beginning to ripen from Mray 15 th to 20 th-just as the strawberry crop is waning. It is wonderfully prolific, the first or main crop being far greater than that of any other red rariety known.

It fruits on the old canes in generous quantities until late in August. By that date berries begin to ripen upon the young canes, which continue to produce berries in increasing numbers until serere frost.

The berries are a bright crimson, of large size and surpassing quality-rich, sugary, with full raspberry flavor. They are of exceedingly meaty, firm texture, and keep in good condition longer after being gathered than any other red raspberry. The canes are of stocky, strong growth, with a great abundance of dark green leathery leaves, that never seald or sunburn. 


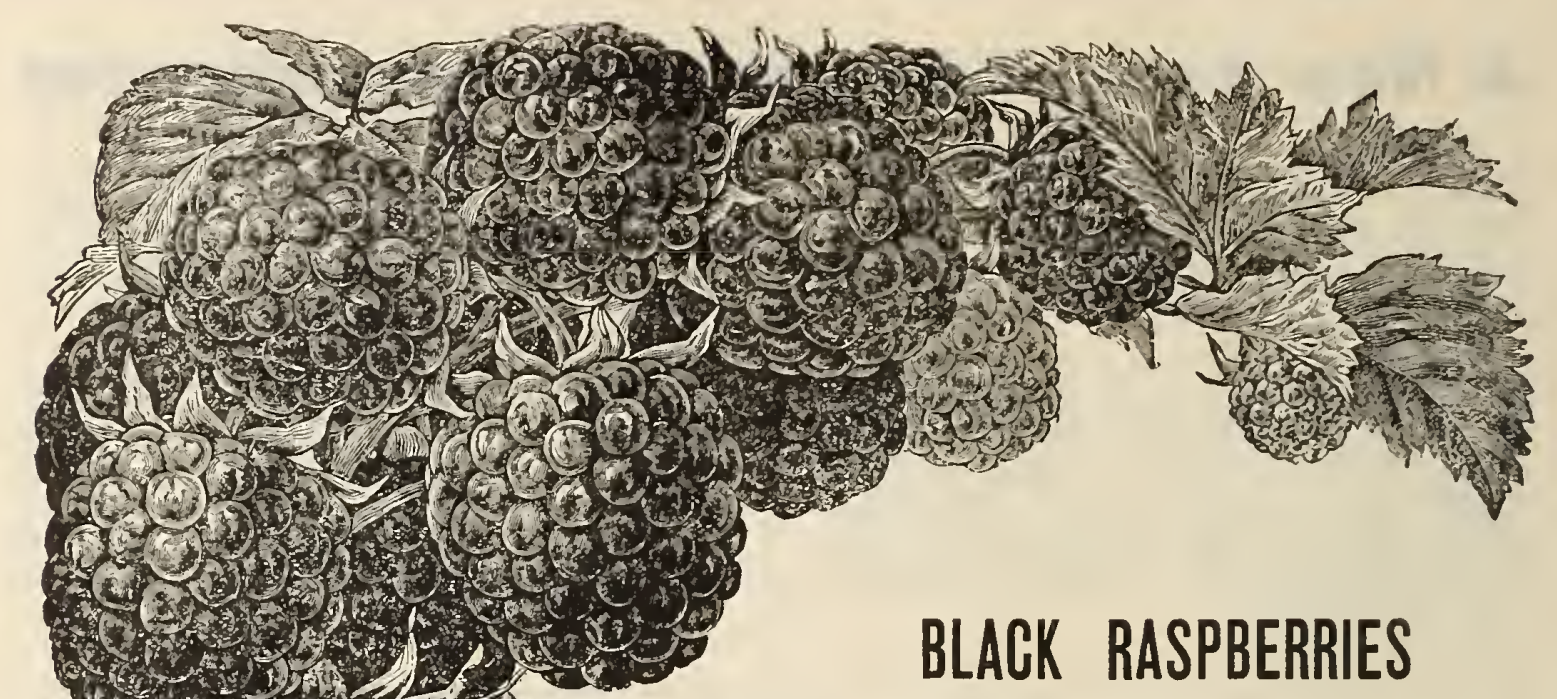

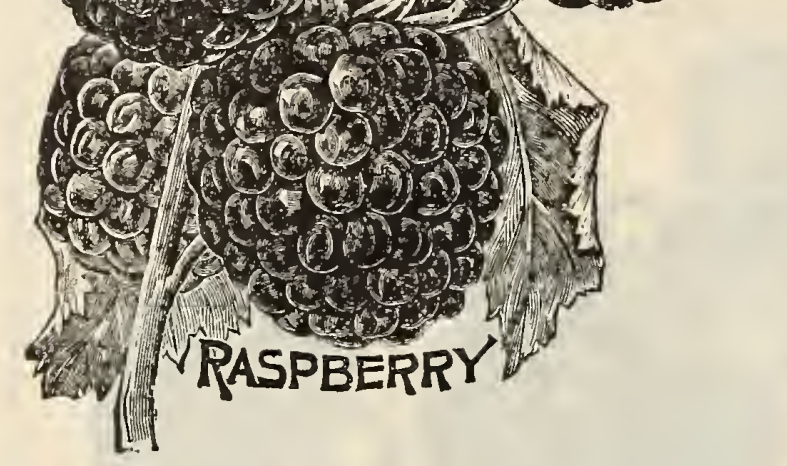

\section{RED RASPBERRIES}

Price, except where noted, 5 cents each; 50 cents per dozen; $\$ 3.00$ per 100 . If wanted by mail, add 10 cents per dozen to prepay postage.

BRILIIANT. New red Raspberry, noted for its productiveness and hardiness; ripens its fruit early and quick. Berries large, beautiful brilliant, just as the name implies.

CARDINAL. This wonderful berry is a surprise in the fullness of its merits-great growth, extreme hardiness and wonderful productiveness. It will produce rich, red, pure flavored fruit in marvelous abundance.

CUTHBERT. Canes hardy. Berries large, dark crimson; good flavor.

MILLER. An early variety, large fruited and profuse bearer: vigorous grower, with large and abundant foliage; color, brilliant red; sweet, luscious flavor.

PHENOMENAL. This new red Raspberry is one of Burbank's latest productions; claimed to be.much larger than the average raspberry. A cross of the California dewberry and Cutbbert Raspberry.

RUBY. A grand variety; ripens rery early, with the King. Its fruit is very large, bright red in color, exceedingly firm and of good flavor.

SHAFFER COLOSSAL. Will revolutionize raspberry growing in the South, as it succeeds on all kinds of soil It neither the South, as it succeeds on all kinds of soil. wither and produces more to the acre than any we know. It is the largest of all raspberries. The color is purplish red; after canning better than any other.

TURNER. (Southern Thornless.) It is extremely hardy and desirable as an early sort for the home garden, bnt too soft for market pnrposes. The canes make a strong. healthy growth, and are very productive. Berries of good size; bright crimsols color; soft and of honeyed sweetness.

THE KING. The earliest red Raspberry. Large fruit, light crimson; quality excellent. Price, 60 cento per dozen; $\$ 4.00$ per $100 ; \$ 35.00$ per 1,000 .
Price, except where noted, 5 cents each; 50 cents per dozen; $\$ 3.00$ per 100 . If wanted by mail, add 10 cent per dozen to prepay postage.

BIACK DIAMOND. A healthy, vigorous grower Berries about the size of Gregg. Ripens early. The sweetest berry known. Fine flavor; few seeds.

CUMBERLAND. In size the fruit is simply enormons, the berries measuring seven-eighths and fifteen-sixteenths of an inch in diameter; but in spite of this, the fruit is unnsually firm.

COLUMBIAN. Most desirable for garden. A seed ling of Cuthbert, which grew near a Gregg. Vigorous, hardy, productive: fruit of large size and great excellence. Dark purple.

EARHEART EVERBEARING. One of the best of everbearing Raspberries, producing a moderate crop on last year's canes at the usual season and a second crop in September upon the new canes.

GREGG. This is the extra big, late, blue-black fellow.

HAYMAKER. A purple Raspberry, not so dark as Columbian; larger and firmer than that fine sort.

KANSAS. A new variety of superior merit; nearly as large as Gregg, and several days earlier; very firm handsome and excellent quality.

MUNGER. The fruit is black and resembles Gregs very much. It is better flavored and a better shipper. In size it excels Gregg.

PIUM FARMER. A variety from northern New York, and and a few days later than Palmer, maturing the entire crop in a very short period, making one of the most profitable early market sorts. The berries are thick meated, firm with a bloom similar to Gregg. Berry large and rery attractive when picked ready for market.
of trial in the home garden and commercial field.

STONE FORT. Extra early, ripening with the late strawberries; large, firm, jet black and of delicious flavor.

\section{DEWBERRIES}

AUSTIN'S IMPROVED. The berries are much larger than any other dewberry; ripens a week or ten days ahesd of any other variety; productive. Price, 10 cents each; 50 cents per dozen; $\$ 2.00$ per 100 .

ABBINO WHITE DEWBERRY. Very productive; large size and of extra fine quality, without any hard core. Price, 10 cents each; 50 cents per dozen; $\$ 2.00$ per 100

IUCRETIA. The fruit is richer and far more proliflc than any known variety. Price, 10 cents each; 50 cents per dozen; $\$ 2.00$ per 100 .

NEW DEWBERRY PREMO. Much like Lucretia, but very distinct and exceedingly early; of excellent quality: $\$ 2.00$ per 100 . 


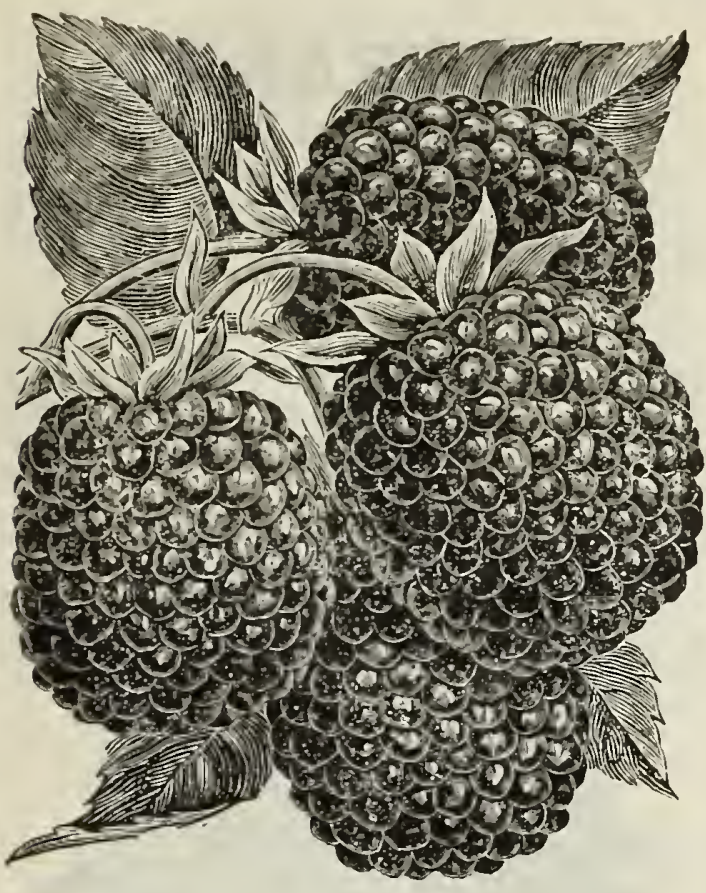

Blackberries

Price, 50 cents per dozen, except where noted; thirty for $\$ 1.00$, except where noted. Six sold at dozen rate. Will quote special low rates on 1,000 lots. If wanted by mail, add 25 cents per dozen to prepay postage.

AGAWAM. Medium size; jet black; very sweet; no core; raluable, especially for home use.

ANCIENT BRITON. Very vigorous, healthy and hardy, producing large fruit stems, loaded with good sized ber. ries of fine quality.

BLOWERS. The berries are very large, equal in size to any blackberry we have seen: luscious and rich in quality; winter never kills; a prolific heavy cropper; ro. quality; winter nev
bust, healthy habit.

CRYSTAL WHITE. A true Blackberry, hardy and prolific; berries medium in size; pure white and of sweet luscious flavor. Truly a great novelty and a surprise to everyone.

EARLY HARVEST. Berries uniform glossy black. Very early.

EARLY KING, A grand, very early variety. Its delicious sweetness renders it especially valuable for the home garden.

ERIE. Canes of ironclad hardiness, strongest growth; free from all diseases, and wonderfully productive. Berry largest size; excellent quality, handsome and firm; early.

HONEY CORELESS. The berry is large in size, sur. passing the Erie or Minnewaski in size; color, jet black: rery firm, sweet, tender, and melting to the very core when fully ripe.

KENOYER. This new variety originated in Kansas, a cross between Early Harvest and Kittatinny; one among the best of the earliest varieties, ripening several days in advance of Early Harvest, and twice as large; of excellent flavor and quality; rich glossy.

KITTATINNY. Once the most popular of all blackberries.

IAWTON. An old favorite esteemed for its productiveness and large size; delicious when fully ripe.

MERSEREAU. A mammoth, early, ironclad hardy berry. Exceptionally sweet and melting, being without core. An enormous yielder.

MAXWELL EARLY. Very large, sweet, rich and luscious; no core whatever; very productive; ripens before strawberries are gone.
MINNEWASKII. One of the largest. Very productive; fruit tender; without core; glossy black, with fine flavor.

NICK OHMER. Large, late and profitable. In both cane and fruit it is all that can be desired.

RATHBUN. The fruit is very large and handsome, intense black, with a very high polish and without any hard core; juicy, high flnvored: of so supcrior a that it is in a class by itself. It ripens early, about with the Wilson.

ROBINSON'S WONDER. Claiming it to be the best and most valuable variety that has appeared since the advent of the Wilson berry; large to very large, of flnest flavor when fully ripe. Ripens early to midseason; valuable for home use and a good shipper; a prolific bearer and as hardy as Snyder. Drouth seems to affect it less than any others. Stout, healthy growth, free from rust or disease. Price, 25 cents each; $\$ 1.00$ per dozen; $\$ 4.00$ per 100 .

SNYDER. Wonderfully productive; sweet and juicy.

STONE'S HARDY. Very hardy, sweet and productive, weighing its strong canes low with its burden of fruit; very suitable for a cold climate.

TAYLOR. One of the largest; fruit of the best quality, melting, and without core; hardy as Snyder berries much larger; one of the most productive; ripens late.

WARD. Is a good shipper; perfectly hardy; no super. fluous sprouts; a great yielder of large blackberries; rich and sweet; no hard cores; fruit all on outside; essily harvested.

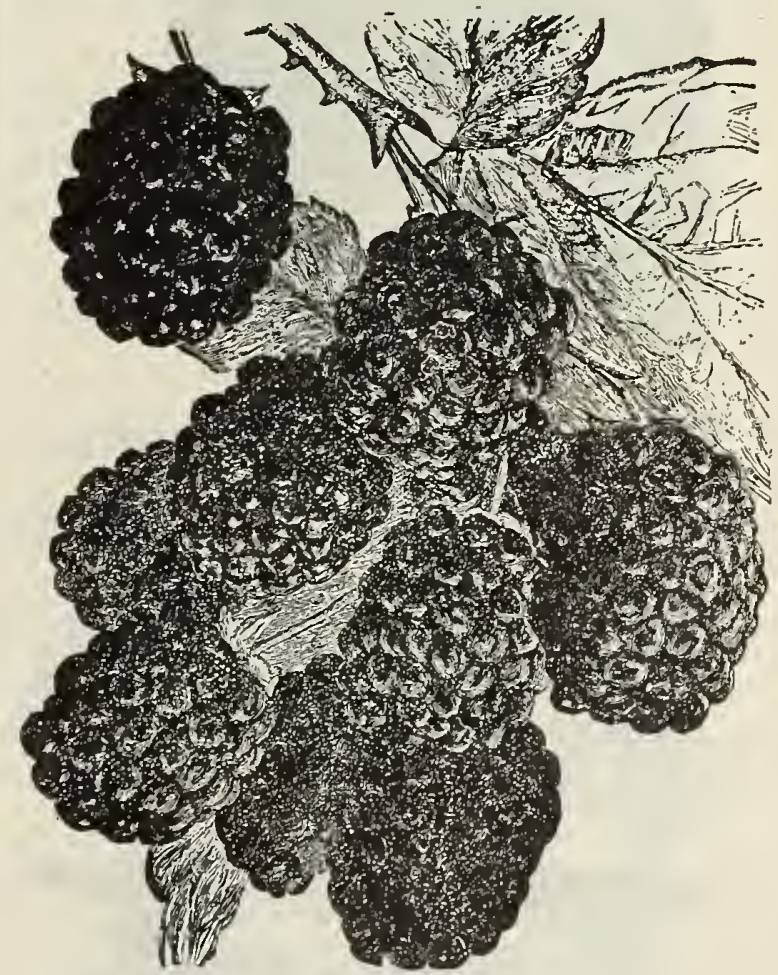

WILSON'S EARLY. Of larget size; very early; beau tiful dark color; of sweet, excellent flavor, and very pro ductive; ripens the whole crop nearly together.

WILSON'S JUNIOR. Isarge and productive; originated from seed of Wilson's Early, which it resembles.

WHITE ICEBERG. As productive, hardy, abundant handsome and delicious as black ones. Canes loadef with delicions snowy white berries.

TAKE ADVANTAGE OF

\section{OUR 10 PER CENT DELIVERY OFFER}

We will undertake to forward any order, prepaid, to any point in the United States and guarantee safe delivery for the small sum of 10 cents additional on each dollar to the total amount of the order. 


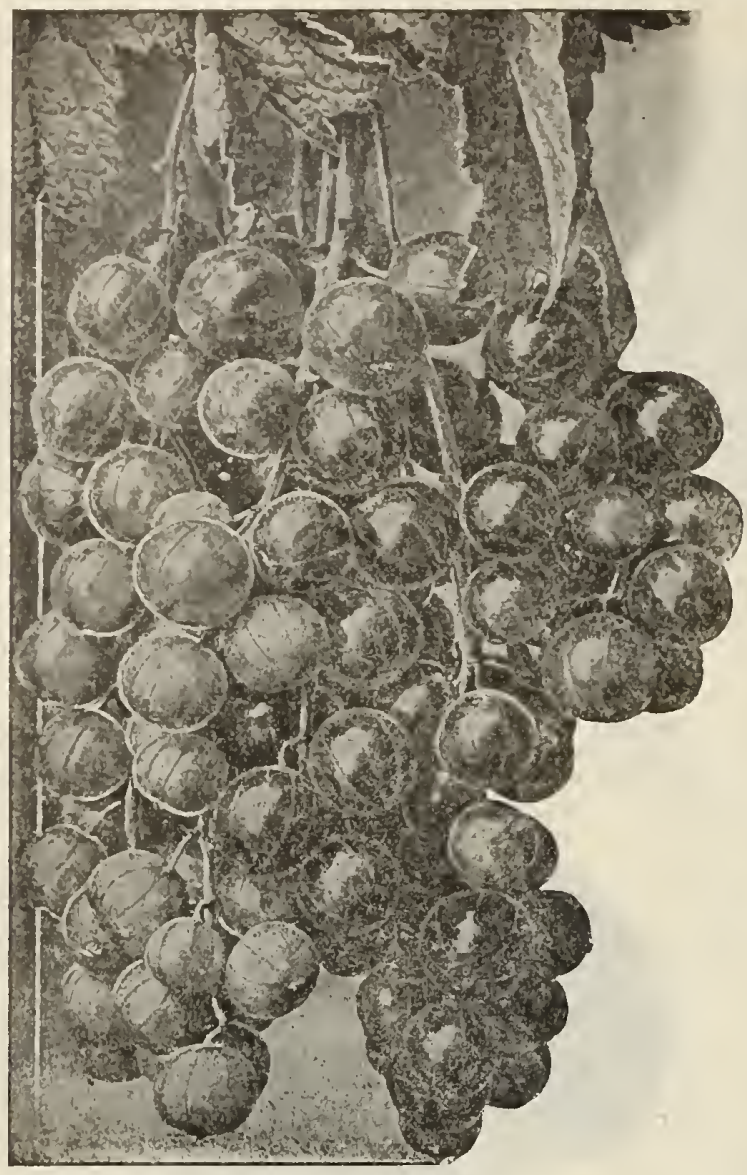

Fay's Currants

\section{SCUPPERNONG GRAPE VINES}

This rariety is purely Southern, and is of no value to the Northern or TVestern States. The vine is free from all diseases; fruit nerer decays. Plant twenty to thirty feet apart in rows. Train on arbor or trellis, and nerer trim. The product is very large and cultivation reduced to simple form. Price, one and two jear old vines, 25 to 50 cents each, according to size.

JAMES BLACK. Berries blueblack, large size, in clusters of from six to ten; skin rery thin; pulp tough, sweet and juicy.

SCUPPERNONG. Berries large, seldom more than eight to ten to a cluster: color, brownish white; skin thick: flesh pulpy; very vinous, sweet and of a peculiar musky aroma; a wonderfully prolific wine grape.

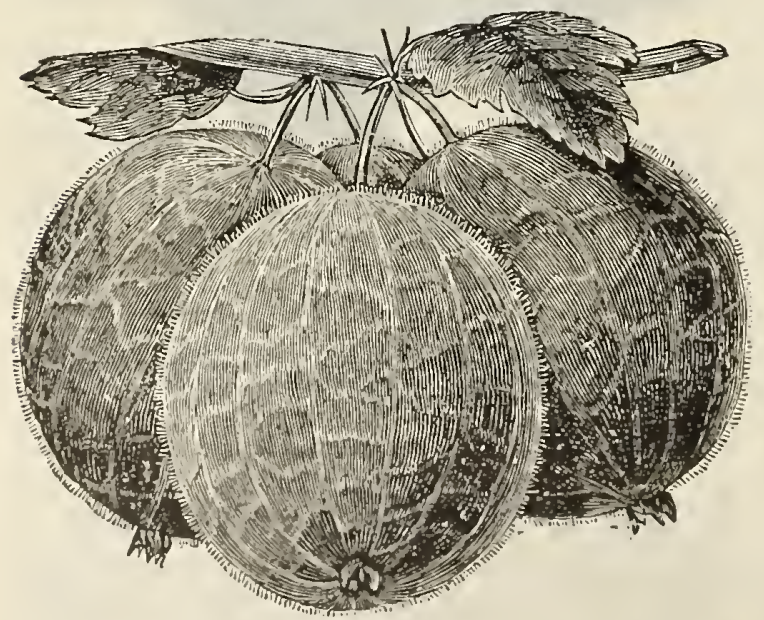

Gooseberries

\section{CURRANTS}

This fruit comes partly with the rasplerry lout follows it sereral weeks. Indeed none of the sunil fruits will remain so long on the bushes without injury as the Currant. Set four feet apart in rich ground: cultirate well or mulch heavily. shoot will have room to grow. If the currant worms appear, dust with hellebore; manure freely.

FAY'S PROLIFIC. Verer since its introtuction has there leen enourh plants to supply the d mand for this, one of the best red Currants: its quick jump into popular faror as soon as tested, the erer increasing demand show's that all claims made for it have heen more than fulfiled. Large stems and berries, uniform in size, rery productive easily picked. For home use or market, the leading va. riety. Price, 10 cents each; $\$ 1.00$ per dozen.

LARGE RED CHERRY. A popular market sort. Bunches large; berries rery large; bright. sparkling crimson: plants, \$1.00 per dozen.

WHITE GRAPE. The largest and deciledly the best white variety, and one of the best of any tor the home garden. Bunch large and long; berry large, landsome, translucent white and of the best quality being less acid than the others. Price, 10 cents each; two year old plants, $\$ 1.00$ per dozen.

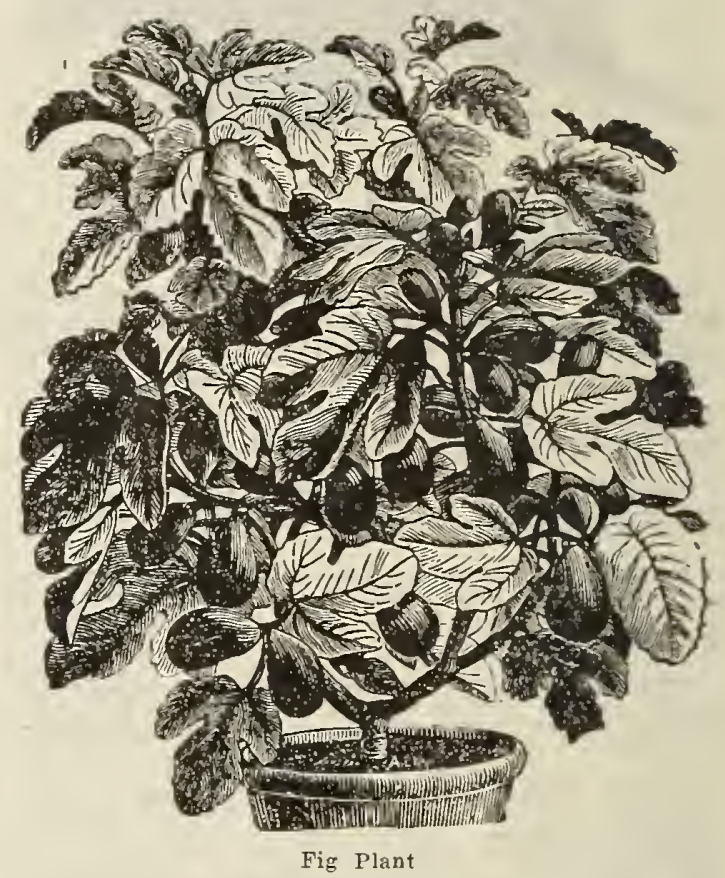

FIGS

The below named sorts succeed well here. Price, two to three feet size, 25 cents each; ten for $\$ 2.00$; three to four feet size, 50 cents each; ten for $\$ 3.00$.

BROWN TURKEY. Medium brown; sweet and excellent; very prolific and reliable.

BRUNSWIOK. Tery large riolet; quality good, and prodnctive.

CELESTIAL. Makes large trees; hardy farther north than most other varieties. Small, pale riolet fruit, fne fiarored, rery early, commencing to ripen in June and continuing two months.

\section{GOOSEBERRIES}

Plant three to four feet each way; manure well; after fruit is gathered prune out all old wood.

HOUGHTON'S SEEDLING. Small to medium; roundish oral, pale red, sweet, tender, rery good: plants spreading: shoots slender; enormously productire. Price, 10 cents each; $\$ 1.00$ per dozen. 


\section{ASPARAGUS}

Strong roots, 25 cents per dozen; $\$ 1.00$ per $50 ; \$ 1.50$ per 100.

COLUMBIAN MAMMOTH WHITE. It produces shoots that are white and remain so as long as fit for usc.

CONOVER'S COLOSSAL. A manmoth variety; of vigorous growth; color, deep grcen.

PALMETTO. A variety of excellent quality. Early, large and prolific.

EARLY FRENCH GIANT. Clained to be an improrc. ment on Palmetto.

CAROLINA QUEEN. A raricty largely planted in the Carolinas for the New Fork market; early, productive; strong grower; superb quality.

DONALD'S ELMIRA. Laree, tender and productive; rery late.

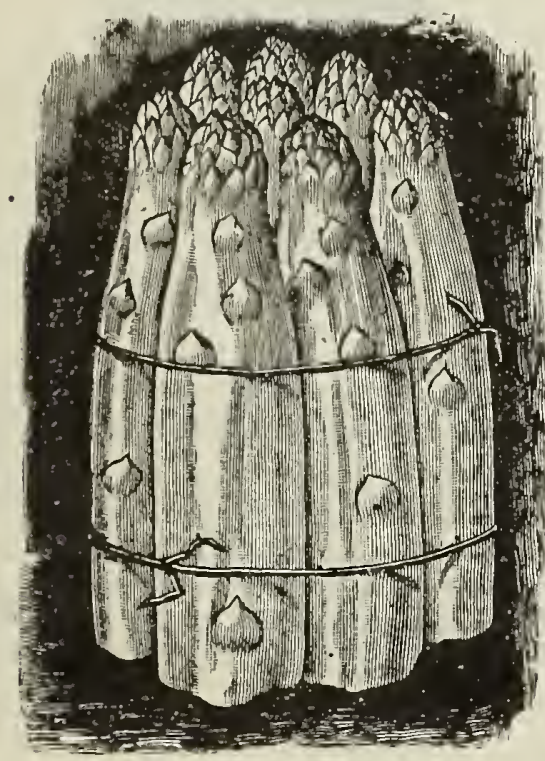

Asparagus

\section{JAPAN PERSIMMONS}

The fruit raries in color and shape. The dark fleshed varieties are never astringent, but the lighter fleshed varieties should never be eatcn until soft. The flesh also raries in color in the pointed rarieties, being usually deep orange. In these it remains solid and quite astringent until November, but becomes soft and edible when house ripened. Tarieties we offer are well adapted to this latitude, in four distinct named sorts. Price, 50 cents each.

\section{PAWPAW}

(American Custard Apple.)

Fruit resembles a small banana: yellow; pulpy; aromatic; relished by some people. Price, 25 cents each.

\section{ROCKY MOUNTAIN CHERRY (Improved Dwarf.)}

From the mountains of Cnlorado. Makes a bush four or fire feet high, usully fruiting in two years, producing larce quantities of jet black fruit about the size of English Morello and ripening after all other cherries are English Morello and ripening
gone. Price, 25 cents each.

\section{POPCORN}

Price, four sorts mixed or in separate colors, 25 cents per pound; four pounds for 75 cents. If wanted sent by mail, add 15 cents per pound to price.

SILVER IACE OR PEARL.

QUEEN'S GOLDEN.

BOY'S FAVORITE.

SPECKLED.

\section{DWARF JUNEBERRIES}

The Dwarf Junebcrry is an cxcellent substitute for the swamp whortleberry or luckleberry, but is of the easicst culturc. The fruit is borne in clusters reddish purple. changing to bluish black. In flavor it is of a mild, sub-acid, execllent as a desert iruit or canned. Price, 15 cents each; ten for $\$ 1.00 ; \$ 5.00$ per hundred.

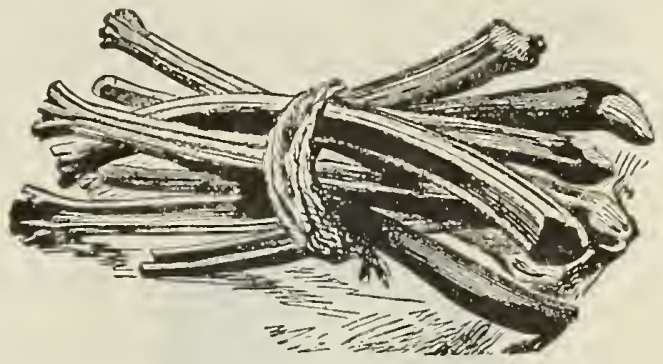

Rhubarb

\section{RHUBARB}

This deserres to be ranked among the best early fruits in the garden. It affords the earliest material for pies and tarts.

LINNAEUS. Large, early, tender and fine. The rery best of all. Price, large divided roots, frst class by express, 15 cents each; eight for $\$ 1.00 ; \$ 5.00$ per 100 .

\section{HORSE RADISH}

MALINER KREN. A new variety from Boliemia. The roots grow to an extremely large size, much larger than the common variety, producing on a given area a much larger crop, at least one-third more than the common variety. Price, 5 cents each; 40 cents per dozen; $\$ 1.00$ per 100.

\section{HORSE RADISH SETS}

Choice roots. Price, 25 cents per dozen; 75 cents per $100 ; \$ 6.00$ per 1000 .

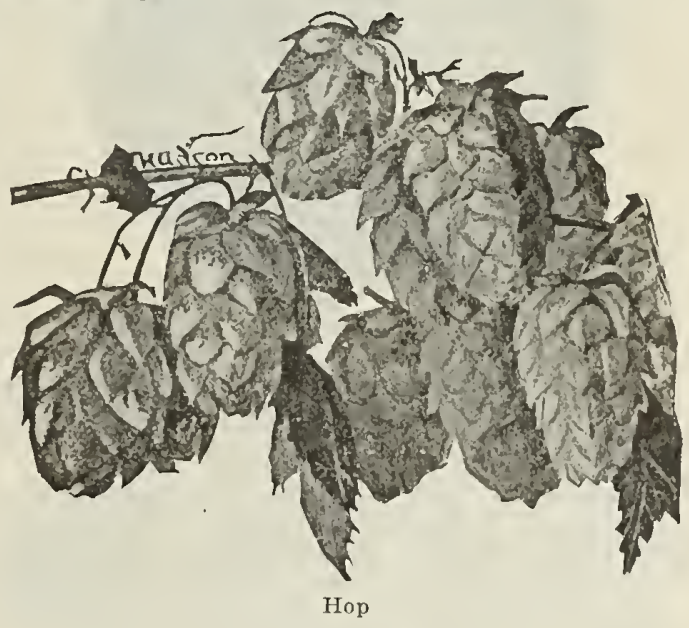

\section{HOP}

GOLDEN CLUSTER. Of rapid growth attaining a height of 20 feet if given support, with abundant or namental, deeply lobed foliage. Golden Cluster is an excedingly choice variety which bears largc clusters of yellow.green hops in such profusion as to completely envelope the plant in late summer and autumn. Price, 15 cents each; four for 50 cents; $\$ 1.25$ per dozen.

\section{PEANUTS}

Price, 25 cents per pound; five pounds for $\$ 1.00$.

IF WANTED SENT BY MAIL, ADD POSTAGE AT RATE OF 15 CENTS PER POUND.

VIRGINIA IMPROVED.

TENNESSEE RED.

SPANISH.

NEW MAMMOTH BUSH. 


\section{NUT BEARING TREES}

ALMONDS. Princess and Sultana. Both are soft sheli; very good. Price, 35 cents each.

ALMONDS. Hard shell. Price, 35 cents each.

AMERICAN SWEET CHESTNUTS. Seedlings. Our native variety. Price, 25 cents each.

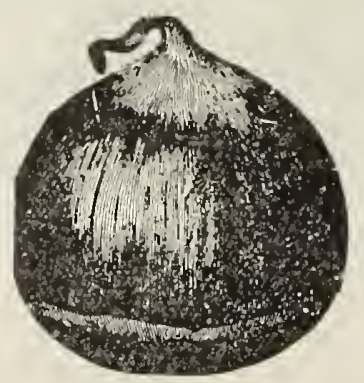

American Chestnut.

JAPAN SWEET CHESTNUTS. Very distinct from all other chestnuts; dwarf grower; hardy and productive; often bears in the nursery rows, trees three or four feet high, being heavily laden with nuts of enormous size; of superior flavor and sweetness when outside skin is re moved. Matures very early before frost. Distinct from moved. Matures very early before frost. Distinct from
European varieties. Price, one year old plants, 50 cents each.

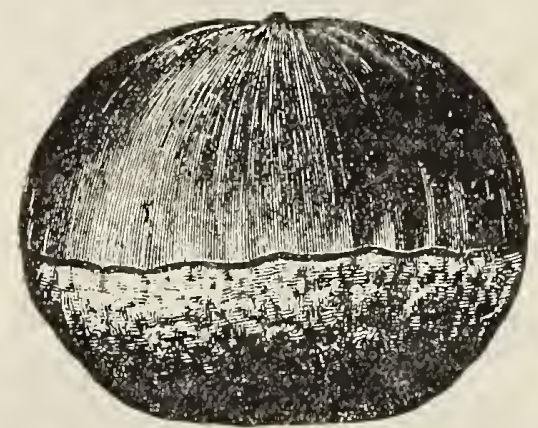

Japan Chestnut

LARGE SPANISH CHESTNUTS. Yields very large nuts. Not as sweet as the American, but their size and beautiful appearance command a ready sale. Price, 35 cents each.

CHINKAPINS. Rush, Hybrid. Price, 75 cents each.

FILBERTS. Of easy culture, growing six to eight feet. Bushy habit. Will grow in almost any soil, and require but little space. Price, 35 cents each.

HAZEL NUTS. Named sorts. Price, 35 cents each.

AMERICAN. Price, 25 cents each.

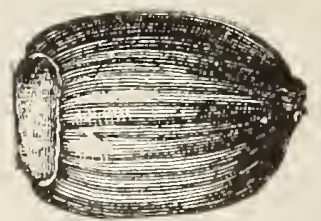

Filbert

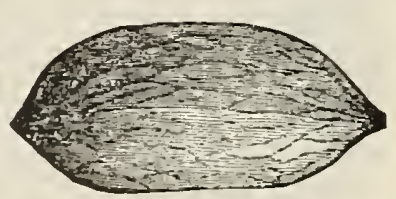

Pecsn
PECAN. Louisiana Soft Shell. Seedlings from solected nuts. Price, two leet, 25 cents each.

PECAN. Budded and grafted sorts in best commercial varieties, Price, $\$ 1.00$ each.
ENGLISH WALNUTS. Early bearing or Prae-parturicnsis. The most desirable variety of this class: tree of low growth; begins to produce nuts when four old. Nuts are good quality, and mature early in the fall. Price, 50 cents each.

ENGLISH WALNUTS. Thin shelled or Maderia. Nuts large, oblong; shell very thin; of excellent quality, and leep sweet for a long time. Price, 50 cents each.

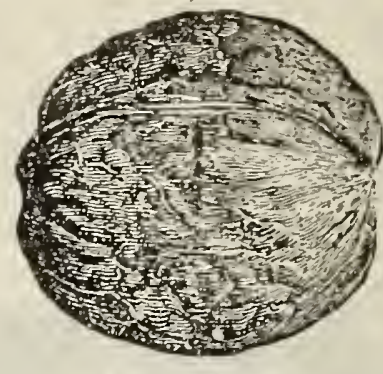

English Walnut

BURBANES SANTA ROSA ENGLISH WALNUTS. Price, 50 cents each.

BUTTERNUT WALNUTS. Well known and popular; low growing native American trees of spreading habit. The nuts differ from those of the Block Walnnt in being longer, and the kernels are of sweeter and more delicate flavor. Price, 50 cents each.

JAPAN WALNUT SIEBOLDIANA. Perfectly hardy; a rapid grower; handsome form; immense leaves; bears young and abundantly; one of the finest ornamental trees. Nuts produced in clusters; resembles Butternut in shape and quality, only smaller, with smooth thin shell, like English Walnut. Worthy of extensive planting. Succeeds well in this latitude; one tree in bearing for six years. As hardy as an oak. Price, 50 cents each.

JAPAN WALNUT CORDIFORMIS. Resembles in some respects Sieboldiana, but differs considerably in form of nuts, which are broad pointed and slightly flattened, somewhat resembling shell bark hickory nuts-if' cracked, longitudinally the kernal can be removed in one piece. Price, 50 cents each.

\section{FRUIT TREES}

We have to offer to the home retail trade a select list of fruit trees adapted to this locality, both early and late varieties, true to name. Price, Apple and Peach, 25 cents each; Pear, Plum and Cherry, 35 cents to 40 cents each; Apricots and Nectarines, 35 cents each. When packed for shipment an additional charge of 5 cents per tree will be added to cover cost of packing.

\section{DOUBLE FLOWERING PEACHES}

During March or April these trees are covered with a mass of beautifully formed and highly colored flowers. They cannot be too highly recommended for soring blossoming. We offer three distinct colors-Double Pink. Double White and Double Crimson. Price, 50 cents each; three for $\$ 1.00$.

\section{FLOWERING CRABS}

BECHTEL'S. Makes a medium sized tree; perfectly hardy; succeeds well in all soils not extremely wet. When in bloom it appears to be covered with delicate pink perfectly double small roses of delicious fragrance. The only sweet scented double crab. Price, 35 cents each; three for $\$ 1.00$.

PARKMANI. A fine companion for abore, with long stemmed semi-double flowers of deep rose color wreathing its branches. It makes a fine compact growth and its deep green leaves are retained qnite late. The buds are long and handsome. Price, 35 cents each; three for $\$ 1.00$.

\section{SPECIAL NOTICE}

We accept Stamps in amounts less than One Dollar, when Post Office IIoney Order cannot be had. Send the new Parcel Post Stamps and not the ordinary Postage Stamps. None but Stamps in perfect condition accepted. 


\section{Reliable Flower Seeds}

We inport our Flower Seeds from the most reliable growers in Germany, also securing some of the best stocka Frown by American specialists, and can conflently recommend them to our customers as being the beat that money can buy. Our Flower Seed List las bcen carefully revised; all inferior kinds cast out and many new kinda added, and it now includes only the most popular, desirable and easily grown varieties. There is nothing in the list but what is well worthy of cultivation, and, if reasonahly cared for, will give satisfaction. We find it almost the universal desire of our patrons to produce the greatest possible assortment in each packet. To fully meet this demand we purchase the different varieties of eacb class in separate colors, then mix them oursclves, so as to be positive what cach mixture contains. We could buy mixtures from the growers, hut they would be quite inferior to our mixtures. Of some kinds we offer separate colors and named varieties.

\section{BRIEF HINTS ON SOWING AND CULTIVATION}

THE SOIL.-A mellow loam, which is medium between extremes of clay and sand, enriched with a compost of rotted manure and leafmold, is adapted to the generality of flowering plants. Before planting flower heds or horders, be sure that they are a little elerated in the middle, that the water may run off and the plants show to hetter advantage.

SOWING THE SEED OUTSIDE.-Nine-tenths of the failures in flower culture come from improper treatment of the seeds and young plants. We urge every purchaser of our seeds to carefully study the cultural directions printed on each package, and the following general rules: Do not plant any seeds when the ground is wet. Make the surface as fine and smooth as possible. Cover each sort of seed to a depth proportionate to its size. The finest seeds, like Portulaca, Campanula, Digitalis, etc., should be mcrely sprinkled on the surface of the ground and harely covered with finely sifted light mellow soil. Press the soil down firmly over the secd with a brick or short piece of board. For larger seeds, the depth should be regulated according to the size of the aeed. Seeds the size of a pinhead should be sown half an inch deep, and those the size of a pea three-fourths of an inch deep. Procure a bit of lath-it is better if planed smoothabout two feet long; press the edge down into the soil evenly so as to make a groove as deep as the seed is to he planted; acatter the seed along this, allowing four or five of the larger and fifteen or twenty of the smaller seeds to the space one plant is to occupy when grown. Cover the seed by pressing the earth together over them; then turn your lath flatways, and press the soil down firmly and evenly.

BOXES.-When sown in shallow boxes, in the house, see that drainage is provided by boring holes in bottom of box, filling same ahout an inch deep with hroken earthenware, coal ashes, or any rough material that will furnish drainage.

HOW TO TRANSPLANT.-Wben the plants are large enough to handle, they should be tranaplanted to the bed or garden, where they are to hloom. Before taking up water very tboroughly; then, having the bed previously prepared, take the little plants up carefully, being very careful not to allow the sun to shine on the delicate roots. Plant in the bed or garden a little deeper than they were in the seed-bed. Firm the ground around the roots. Water freely at once and kecp well shaded for a few days, unless cloudy. If possible transplant only in the evening or on cloudy days. If shading is necessary on account of the sun is should be removed on cloudy days.

\section{ASTERS \\ (Select Varieties.)}

Astera have become won'derfully popular. We offer below the most distinct types, each of which is unique in style and colors. The seed we offer is grown by an Aster expert.

GIANT COMET. A beautiful and distinct class. Their very large, douhle flowers are often four to five inches across, with long, curling and twisted petals, forming loose half-globes, resembling Chrysanthemums. Plant of luxuriant growth, attaining a height of fifteen inches, each plant producing twenty to thirty magnificent fowera on long stems. We offer four of the moat distinct colors separate, also choicest mixed. Pure White, Light Blue, Dark Blue, Rose. Price per packet, 10 cents; three packeta for 25 cents; six packets for 45 cents. Mixed Colors. Including all of the above and many other colors. Price per packet, 10 centa.

SEMPLE'S BRANCHING. This is a grand new strain of American Asters. They are especially $\nabla$ aluable for cut flowers, because of their handsome double flowers and long stems. They bloom two to three weeks later than most sorts. We offer them in four separate colors. Pure White, Crimson, Lavender, Bright Pink; also Choicest Mixed. Price per packet, 10 cents each; three packets for 25 cents; six packets for 45 cents.

QUEEN OF THE MARKET. This ia a superb variety of graceful, spreading habit. Truly a queen among Asters. It grows ahout twenty inches high. This variety is about two weeks earlier than most other sorta. The flowera are quite large, very double, and are valuable for cut flower purposes. The following are the most distinct colors: Pure White, Rose, Dark Blue and Scarlet. Price per packet, 10 cents; three packets for 25 cents; six packets for 45 cents. Mixed colors, embracing all colors of this class. Price per packet, 10 cents.

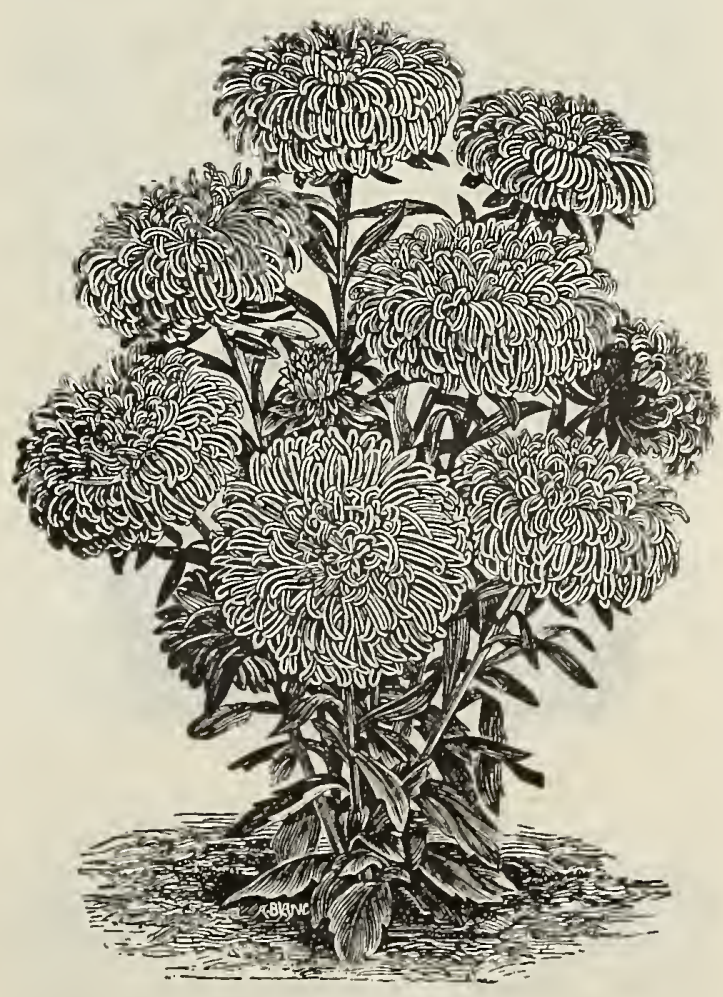

Comet Aster 


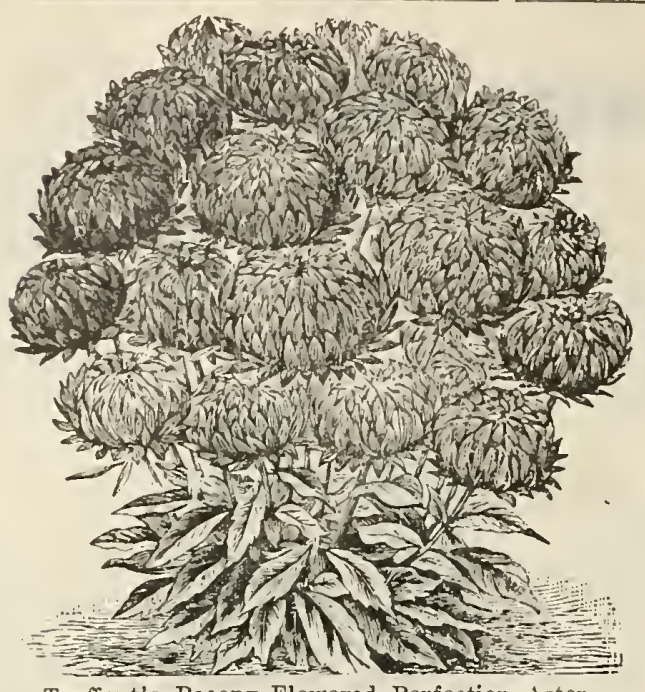

Truffaut's Paeony Flowered Perfection Aster

\section{ASTERS}

TRUFFAUT'S PAEONY FLOWERED PERFECTION. One of the best varieties in every respect. Flowers rery large, double and beautifully incurred; grow about eighteen in the splendid strain we offer. Mixed seed. Price, per packet, 5 cents.

CHRISTMAS TREE. A new type of Aster, of branching, pyramidal form of growth. Flowers range through many beautiful shades of color. Price, per packet, 10 cents.

NEW QUEEN OF SPRING. Of all Asters, it is the earliest. if the seed is started early it will flower in full perfection before the calendar months of spring have ended. The plants are vigorous and healthy, of low, dwarf growth, and produce their queenly white double flowers profusely on long stems, making them unsurpassed for cutting. Price, per packet, 10 cents.

NEW DIAMOND MIXED. The flowers are extremely beautiful two to two and one-half inches across, each petal being distinctly incurved. The plants grow eighteen to twenty inches ligh. The colors range from pure white
to blackisls.purple. and dark ricl crimson. Price, per packet, 10 cents.

NEW DWARF PAEONY PERFECTION, The plants do not grow over twelve inches high, and are of neat compact habit, blooming profusely. Flowers are large, of fine form, perfectly double; the colors are strikingly rich and bril liant. Nixed seed. Price, per packet, 10 cents.

NEW GIANT COMET MIXED. This is a new strain from France, with flowers of large size, closely resemblin curled Chrysantlemums. All colors mixed, Price, per packet, 10 cents.

MIXED ASTERS FOR GENERAL PLANTING. OUT own mixture, embracing niany choice varieties, Price, onefourth ounce, 75 cents.

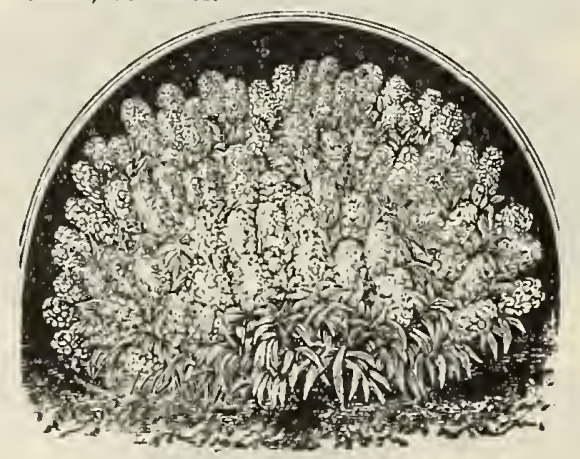

Sweet Alyssum

\section{ALYSSUM}

LITTLE GEM. Plants very dwarf, only three to four They soon become one mass of white, remaining in full bloom from spring to fall. Hardy annual. Price per packet, 5 cents.

SWEET ALYSSUM. Very fragrant; white, Hardy annual. Grows one-half foot high. Price per packet, 5

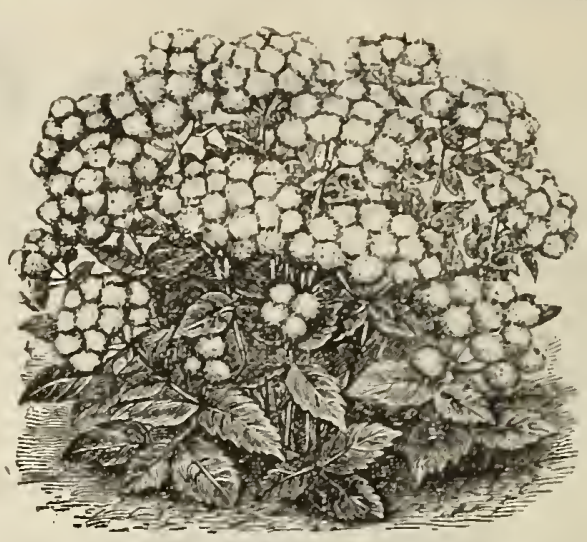

Ageratum

\section{AGERATUM}

(Floss Flower.)

BLUE PERFECTION. Color deep amethyst-blue. Price, per packet, 10 cents.

GRANDIFLORA WHITE. Pure white. Price, per fack-

MIXED. Consisting of white, light biue and dark blue. Price, per packet, 10 cents.

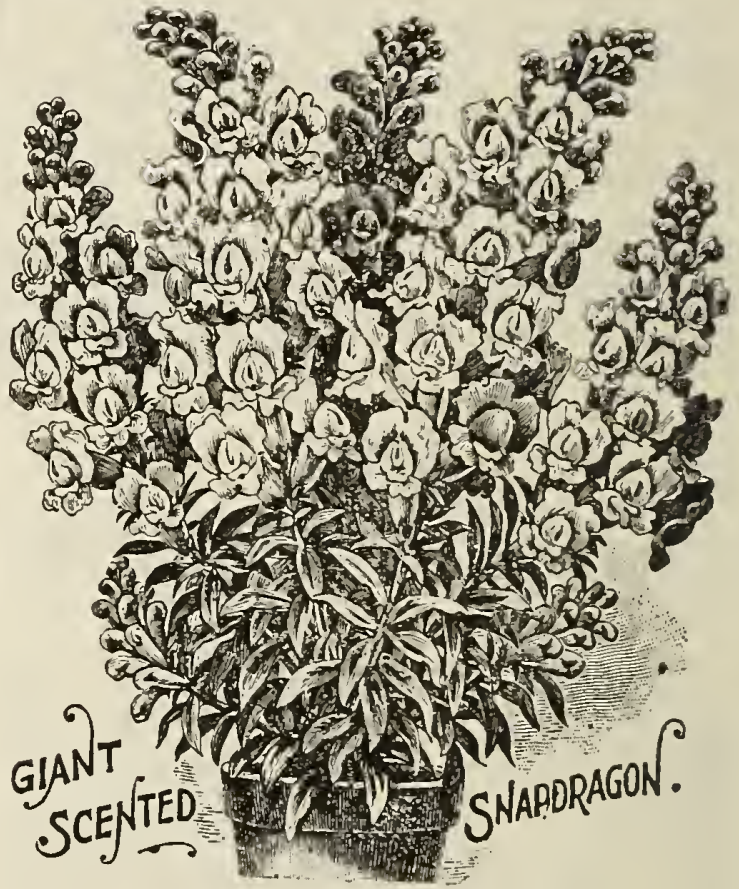

\section{ANTIRRHINUM}

\section{(Snapdragon.)}

Nothing has been more improved in the past few years than the Antirrhinum and they are now very popular and fashionable. Sown in spring they bloom from midsum. mer until frost. They succeed best in light soil in a sunny position. They are liardy perennials, but can be

QUEEN VICTORIA. Purest white. Price, per packot, 10 cents.

BLACK PRINCE. Dark crimson. Price, per packet, 10 cents.

LUTEUM. Sulphur yellow. Price, per packet, 10 cents. ROSEUM. Brilliant pink. Price, per packet, 10 cents. FIRE KING. Orange and scarlet. Price, per packet, 10 cents.

VENUS, Delicate pink. Price, per packet, 15 cents.

GLANT FLOWERED MIXED. A mixture of the newest arieties, having flower spikes nearly foot long of brilliant colors. Price, per packet, 10 cents. 


\section{AMARANTHUS}

Brilliant-folliaged annmals, growing from three to fivc fect ligh, snme of the varicties bearing curious racemes of flowers. They should not be grown too closely together. JOSEPH'S COAT. Foliage red, grcen and yellow. Price, per packet, 5 cents.

PRINCE'S FEATHER. Brilliant foliage, red feather-like flowers; fine. Price, 5 ccnts per packet.

SUNRISE. The most brilliant of this brilliant family. The foliage is bronzy crimson, cach branch terminating with a tuft of briglit senrlet-carmine leaves. Price, 10 cents per packet.

\section{AQUILEGIA.}

(Columbine.)

A hardy" plant, especially good for rockeries or shady corners. Seed should be sown early in the spring and thinned out to twelre inclies apart.

DOUBLE VARIETIES. Finest Mixed. Price, per packet, 10 cents.

SINGLE VARIETIES. Finest mixed. Price, per packet, 5 cents.

\section{ABUTLLON}

(Flowering Maple.)

Elegant flowering perennial slurubs of strong growth and easy cultivation, frce flowering, with rarious colored, beautiful drooping, bell-shaped flowers. Prize mixture producing all shades of fiowers, yellow, orange, white and scarlet. Price, per packet, 10 cents.

\section{ALEGHENY VINE}

ADLUMIA CIRRHOSA. A graceful hardy climber; the feathery foliage closely resembles that of the Maiden Hair Fern, the flowers are tube shaped, flesh colored, and completely cover the plant. The first year after seed is planted a bushy plant is formed witl a fleshy root, which is hardy. The next rear this root sends up vines, delicate and lacelike. Soak seeds in warm water before sowing. Price, per packet, 10 cents.

\section{BALLOON VINE.}

(Cardiospermum.)

A rapid growing plant. Succeeds best in light soil and warm situation. Flowers white. Half hardy annual. Five feet. Price per packet, 5 cents.

\section{BEAN RUNNER}

A rapid climber, flowering profusely; grows 10 to 15 feet high.

BUTTERFLY RUNNER. A new and distinct variety; the flowers are of larme size and borne in oreat profusion; color. pink and white. Price, per packet, 5 cents.

\section{SCARIET RUNNER}

One of the best climbers known. As easy to grow as a garden bean. Tines will run from fifteen to twenty feet in a season with good dark green foliage and long branches of brilliant scarlet flowers shaped like pea blossomis. A most showy bloomer as the scarlet flowers are succeeded by dark purple seed pods. Price, per packet, 5 cents.

\section{BRYONOPSIS IACINIOSA}

A beautiful annual climber of the ground species, with iry-like pale green foliage and showy fruit-first green striped white, turning, when ripe, to bright searlet striped white. Teh feet. Price, per packet, 5 cents.

\section{BROWALLIA}

One of our favorite bedding plants, producing beautiful lowers during the summer and autumn months; grows freely in any rich soil; blooms finely in the winter if sown in August; 18 inches. Seed may be started in the house from March until May, Large sky-blue flowers. Price, per packet, 5 cents.

\section{BALSAM APPLE}

MONORDICA BALSAMINA. A quick growing climber with ornamental foliage and curious yellow fruits which when open are brilliant scarlet. The fruits are used for medical purposes. Plant seed in light, rich soil when trees arc out in leaf. Price, per packet, 5 cents.

\section{BALSAM PEAR}

MOMORDICA CHARANTIA. The same as Balsam Apple in every particular except the fruits, whicls are six inches and over in length and beautifully colored. Fino medi cinally. Price, per packet, 5 cents.

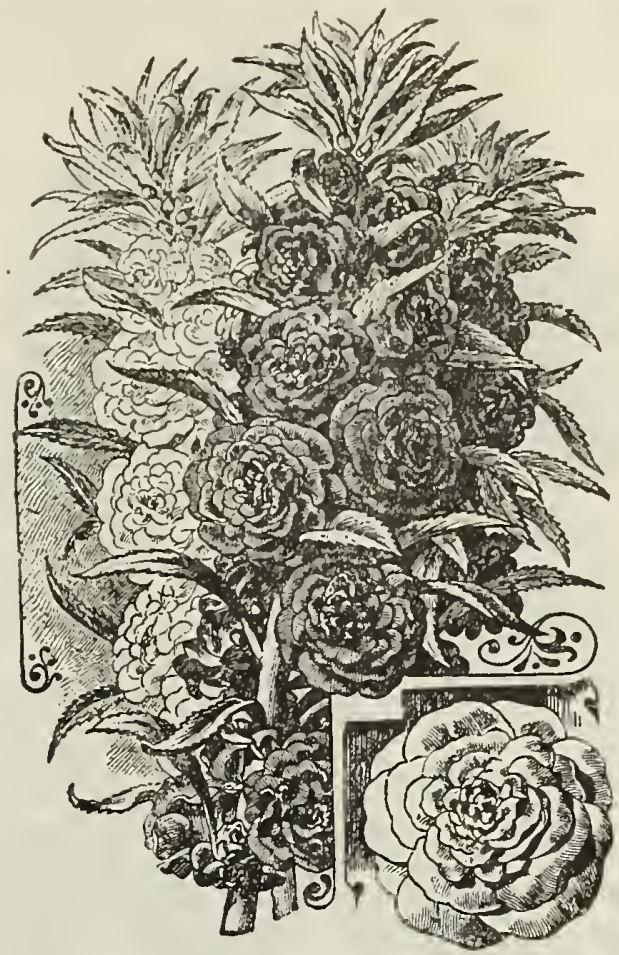

BALSAM

(Lady Slipper.)

An old favorite garden flower, producing its gorgeous masses of beautiful, brilliant colored double flowers in th greatest profusion; of easy culture; succeeds in a good rich soil; tender annuals.

THE ROYAL BALSAMS. These are a new strain of $\mathrm{Bal}$ sams of unsurpassed quality. Stroug, branching growth, and dense masses of bloom.

ROYAL BALSAM, "The King.' Intense glowing scarlet, very fine. Price, per packet, 10 cents.

ROYAL BALSAM, "The Queen."' Pure, bright, satiny rose, an exquisite shade of rich pink. Price, 10 cents per packet.

ROSE-FLOWERED BALSAMS. Improved Double RoseFlowered Mixed. Flowers of this variety are very per fect in shape, much like Roses. Of extra size and extreme ly double; very fine. In color including purple, bright red flesh color, pure white, yellow, lilac, crimson, etc. Price, per packet, 10 cents.

CARNATION STRIPED BALSAMS. A pretty class of Balsams with good double flowers in white, striped with crimson, violet, pink and red. Price, per packet, 5 cents

CAMELLIA.FLOWERED SPOTTED BALSAMS. Im proved Double Camellia-Flowered Mixed. This is an 8 pecially popular variety, having flowers and a great diversity of color, having white blotiles or spots. Price, 5 cents per packet.

NEW WHITE DEFIANCE. Without doubt the finps perfectly double pure white Balsam in cultivation $A$ bsolutely pure white. Price per packet, 10 cents.

\section{CYPRESS VINE}

A slender climber of quick growtl, with finely cu leaves and an abundance of slender, star-shaped flower in brilliant colors. Soak the seed in warm water, and plant when the leaves are starting out on the trees.

BCARLET. Price, per packet, 5 cents.

WHITE. Pure white. Price, per packet, 5 cents.

MIXED. Price, per packet, 5 cents.

\section{CANNAS}

The Canna is one of our most ornamental plants, and is of rery easy culture. Soak seed in warm water for a day or two before planting. Plant seeds onehalf inch deep, one inch apart, in shallow boxes of rich soil early in spring: place in warm, sunny window. When plants show two leaves transplant to pots. and do not set out till nights are quite warm.

EXTRA FINE MIXED. This mixture consists of best seed of named sorts in all colors, scarlet, pink, yellow and variegated. Price, per packet, 5 cents. 

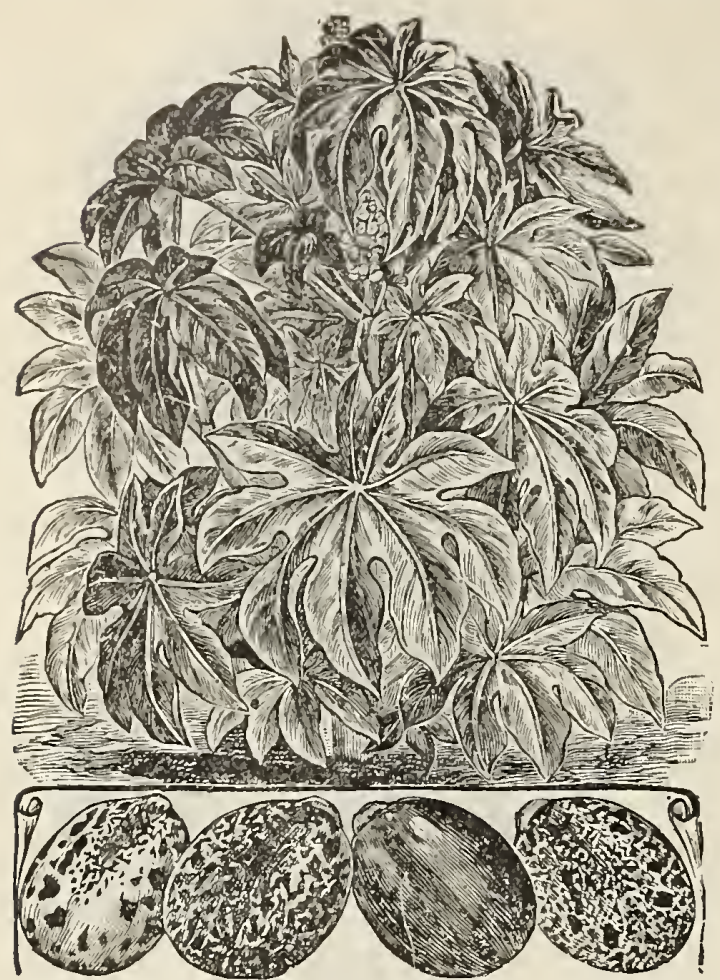

Castor Oil Bean

CATENDULA

(Pot Marigold.)

One of the best and showiest free-flowering hardy annuals, growing in any good garden soil, producing a fine effect in beds or mixed borders, and continuing in hloom until killed hy frost; valuahle also for pot culture, blooming freely in winter and early spring.

FAVORITE. Beautiful double giant flowers of lemon. yellow, striped white. Price, per packet, 5 cents.

ORANGE KING. New. Mammoth fiowers of rich orange-yellow; very fine. Price, per packet, 5 cents.

\section{COWSLIP}

PRIMULA VERIS. A beautiful hardy spring flowering perennial; flowers of different colors, such as yellow, brown-edged yellow, etc. Very fragrant; six inches high. Price, per packet, 5 cents.

\section{CLEOME PUNGENS}

The Giant Spider Plant.)

A robust plant, growing vigorously four to five feet high, unaffected hy wind or weather, and flowering profusely for months. The flowers are of a bright rose color. The long slender seed pods are carried upon still longer stipules, giving the effect of a many legged spider, with the bright hunch of flowers as the head. It grows freely from seed, thrives luxuriantly, and hlooms all summer. It is also one of the very hest honey-producing plants. Price, per packet, 5 cents.

\section{CLARKIA}

Planted in large groups they are very bright and effective, and the long graceful sprays are good for table decorations. cents.

SINGLE MIXED. All colors. Price, per packet, 5 DOUBLE MIXED. All colors. Price, per packet, 5 cents.

\section{CANARY-BIRD VINE}

(Tropaeolum Canariense.)

A heautiful rapid annual climber, the charming little canary-colored hlossoms bearing a fancied resemblance to a hird with its wings half expanded. Price, per packet, 5 conts.

\section{CASTOR OIL BEANS}

(Ricinus.)

This easily grown plant is one of the most tropical looking and handsomest annuals known. From seeds planted in the spring when the nirhts are warm and trees out in leaf, plants will grow to at least twelve feet before frost. The leaves are very large, handsomely cut and are often over two feet across. Blossoms are borne on tall spikes and seed pods ornamental.

CAMBODGENSIS. Large leaves, dark bronzy-maroon; stalk and stems nearly black. Price, per packet, 5 cents. GIBSONI. Branching hahit, decp red foliage. Price, per packet, 5 cents.

PHILLIPPIENSIS. A rariety from the Phillippines; gigantic purple foliage. Price, per packet, 5 cents.

SANGUINEUS. Blood red stalks and clusters of red fruit. Price, per packet, 5 cents,

ZANZIBARIENSIS, Enormous leares varying in color from light green to purplish red. Price, per packet, 5 cents.

MIXED. All sorts. Price, per packet, 5 cents.

\section{COLEUS}

The most beautiful Coleus can be easily raised from seed sown early in the spring, transplanted to pots when large enough to handle. Young plants must not be set out till nights are quite warm, and should be shaded from the sun till well estahlished.

FINE MIXED. This mixture will produce a fine variety of rich colorings in large fine foliaged plants. Price, ver packet, 10 cents.

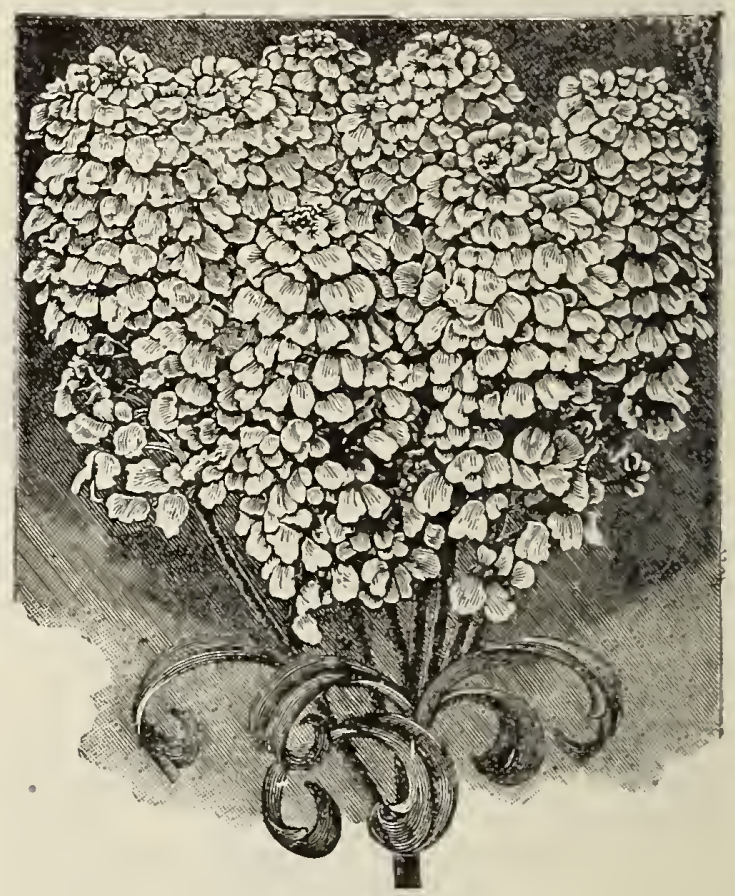

Candytuft

\section{CANDY TUFT}

Dwarf annuals, flowering profusely throughout the whole season. An excellent edging for heds or borders. The plants are covered with hlossoms, and are of the easiest culture. Sow in the spring as soon as the soil can be properly worked.

ROSE CARDINAL. A new Candytuft of very heautiful clear hright rose; flower heads unusually large. Price, per packet, 5 cents.

DARK CRIMSON. The richest dark shade; fine for borders or cutting. Price, per packet, 5 cents.

EMPRESS. Produces large trusses of pure white flowers; an abundant bloomer; fine for cemetery planting. Price, per packet, 5 cents.

MIXED VARIETIES. Including all colors known in Candytuft. Price, per packet, 5 cents.

\section{COBOEA SCANDENS}

(Cups and Saucers Vine.)

In sowing, place the seeds edgewise, and merely cover with light soil.

PURPLE. Price, per packet, 10 cents.

WHITE. Price, per packet, 10 cents. 


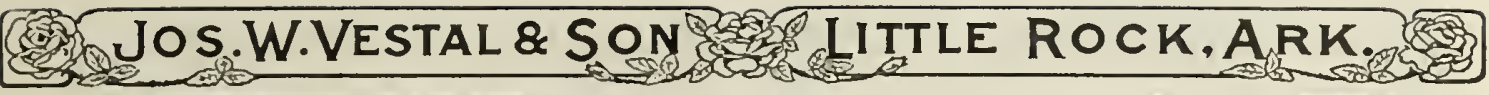

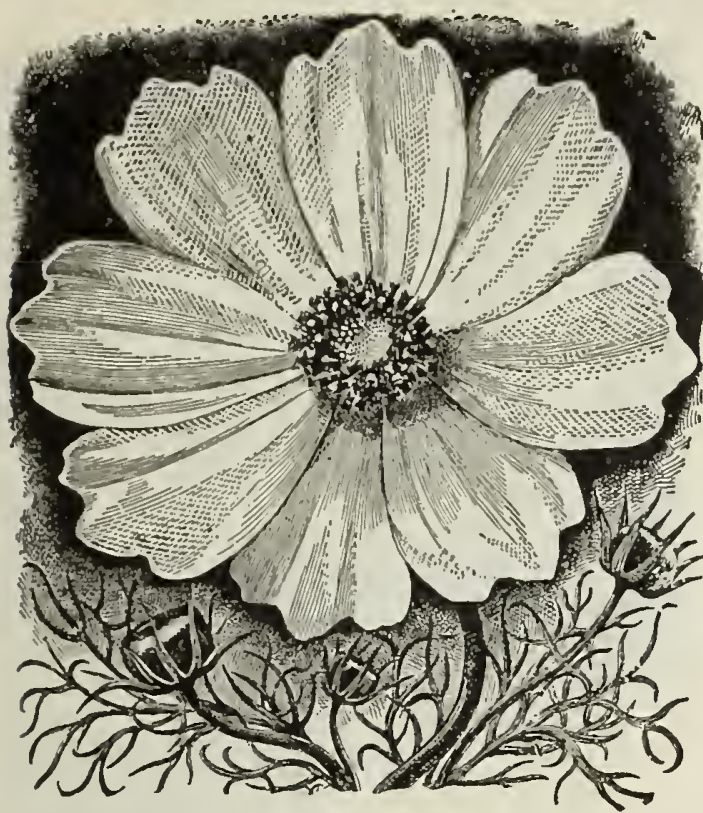

Cosmos

\section{COSMOS}

The new varieties of Cosmos have been so greatly im. proved that the flowers now resemble large single Dahlias. Plants grow at least five feet high, branch freely, covered with fine feathery folinge and a mass of bloom, borne well above the plants on long, slender stems. The flowers range in color from pure white to pink, rose and crimson. Sow the seeds early in the spring and thin out or trans. plant. In cold localities seeds may be started in the plant. earlier to insure grood blooms before frost. In most localities plants bloom from August to November.

MAMMOTH PERFECTION, White, This strain produces the largest flowers, perfectly white, beautifully shaped and in great masses. Fine for cutting. Price, per packet, 10 cents.

MAMMOTH PERFECTION, Pink, The largest flowers in rose-pink come from this seed. Color pure and bright $\rightarrow$ ery fine. Price, per packet, 10 cents.

MAMMOTH PERFECTION, Crimson. A rich velvety Crimson, very brilliant and striking. Price, per packet, 10 cents.

NEW MAMMOTH PERFECTION, Mixed. Flowers of unusual size in all shades of pink, crimson and white. Plants branch very freely, growing about six feet high, and are a mass of bloom above the fine green foliage. Price, per packet, 10 cents.

SUMOMER FLOWERING DWARF COSMOS. Dawn. This variety is of compact growth, growing four or five feet high, and blooming in July, much earlier than the taller varieties, Flowers very large, white shaded to pink in the center. Price, per packet, 10 cents.

SUMMER FLOWERING DWARF, MIXED. All colors. Price, per packet, 5 cents.

\section{CARNATIONS}

Perpetual-Flowering Marguerites,

These Carnotions produce flowers on long stiff stems, in areat and rich variety of colors. Large, double, fringed and fragrant. Sow the seed quite thinly in the garden when the trees are starting out in leaf; transplant or thin out so as to stand ten inches apart. Cultivate carefully, and they will bloom in about twelve weeks and continue to bloom until severe frost. Also will bloom in pots in the house during winter.

GIANT MARGUERITE CARNATION, "Snowflake." A new imported pure white variety; large flowers; very fragrant: excellent for cemetary planting. Price, per packet, 10 cents.

GIANT MARGUERITE CARNATION, Red. A fine rich red, very double and very fragrant. Price, per packet, 10 cents.

GIANT MARGUERITE CARNATION, Pink. An un usual color, very fine; a novelty. Price, per packet, 10 cents.

GIANT MARGUERITE CARNATION, Mized. A fine mixture of red, rose, pink, white and variegated. Price, per packet, 10 cents.

SPECIAL OFFER. One packet each of the three Marguerite Carnations for 25 cents.

\section{ANNUAL CHRYSANTHEMUMS}

\section{NORTHERN STAR}

New Annual Chrysanthemum.

The bloom of this Giant Flowering Chrysanthemum meas ures on an average three and one-lialf iuches across. The robust plants eighteen inches in height. The radiant white of the petals, passing toward the center into soft yellow shows up strikiurly against the bold black disk, and there is no doubt that this new Chrysanthemum will prove a real treasure to growers of flowers for cutting. Price, per packet, 15 cents.

\section{EVENING STAR}

Annual Golden Marguerite

A splendid variety for cutting; flowers three to four inches across, of pure golden-yellow; in general appear ance resembles the yellow Paris Daisy. Price, per packet, 10 cents.

\section{“'BRIDAL ROBE'”}

New Annual Chrysanthemum

Of very compact and upright habit, and not exceeding ten inches in height, the sturdy plants throw out their finely fenthered folinge from the base and deck themselres with a mantle of extra-double pure white flowers. Flowers are like large double Daisies and are massed on the plants; fine for cut flowers. One of the best bedding plants yet introduced. Price, per packet, 10 cents.

\section{CENTAUREAS}

CENTAUREA CYANUS. (Corn Flower, Blue Bottle, Ragged Sailor.) A well known annual growing two feet high and very early. Flowers blue, pink or white. Fine mixed. Price, per packet, 5 cents.

DOUBLE CENTAUREA CYANUS. (Double Cornflower.) Produces double globular heads of flowers of lore size, filled to the center with fringed tubular florets. Very de sirable. Price, per packet, 5 cents.

DUSTY MILLER. (Silver Leaved Centaurea.) A well known plant having a silvery-gray foliage beautifully cut The plants are compact and bushy and are much used for edging flower beds. Price, per packet, 5 cents.

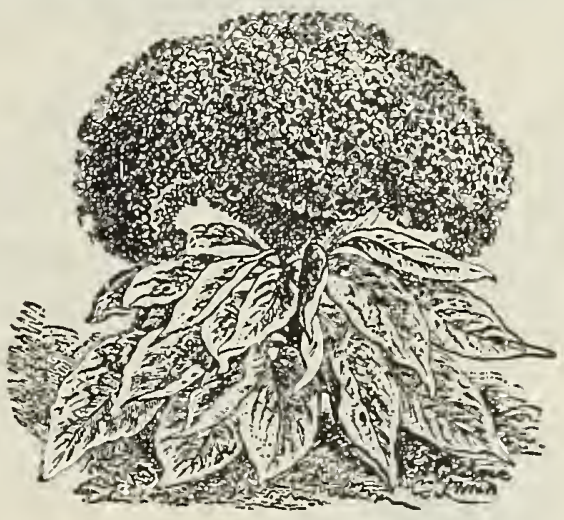

Cockscomb

CELOSIA

(Cockscomb)

Beautiful plants which now grow in two distinct varie ties, crested and plumed, and are fine for borders and massing in beds. Sow seed thinly in shallow drills when trees are starting out in leaf; thin out to give plants room to develop

CRESTED MIXTURE. A mixture of the best sorts in shades of yellow, rose, crimson, scarlet and purple; very fine. Price, per packet, 5 cents.

DWARF MIXED. Fine dwarf varieties of Cockscomb Price, per packet, 5 cents.

NEW PLUMED CELOSIA MAGNIFICENT. This grand plumed Celosia has been admired both for its compact growth and the rich, soft shades of coloring in the feathery plumes. The plants are of broad, rounded form from eigh. teen inches to two feet. Each branch is tipped with a pointed head of richly colored bloom, which later brosdens to a loose, plumy head of the most brilliant color. The colors embrace all shades of orange and yellow, salmon, scarlet and crimson. Price, per packet, 10 cents. 


\section{CAMPANULA}

(Canterbury Bells.)

Tery ornamentul garden plants of the easiest culture. They produce larke, nodding bell shaped flowers, of many beautiful shades-Blue, whitc, purple and spotted. DOUBLE MIXED. Price, per packet, 5 cents. SINGLE MIXED. Price, per packet, 5 cents.

\section{CALLIOPSIS OR COREOPSIS}

show and free flowering anuuals, blooming early and continuing until frost. The flowers are very showy, and excellent for cutting.

GOLDEN WAVE. A very showy sort with large yellow flowers, witl dark brown centers. Price, per packet, 5

IANCEOLATA GRANDIFLORA. Large golden yellow. Price per packet, 5 cents.

\section{DIGITALIS \\ (Foxglove.)}

beatiful class of hardy perennials of easy culture. Plants grow from three to fire feet high and are fine for planting among hardy shrubs. The flowers are orne on long spikes, are very handsome and showy.

GLOXINIA FLORA MIXED. This is the finest strain, rich in color and splendidly mottled. Price, per packet, 10 cents.

MONSTROSA MIXFD I splendid mixture of the large flowering type. Price, per packet, 10 cents.

\section{DIANTHUS}

or Sweet Clove Pinks.

Dianthus, or Sweet Pinks, are now among the most popular flowers cultivated, because the seed may be sown outdoors very early in the spring, and in a few weeks the plants will be a mass of sweet-scented blooms.

Single Annual Sweet Clove Pinks

DIANTHUS NOBILIS, ROYAL PINKS. Selected and improved rarieties of the popular single flowering Japan Pink producing fowers nearly four inches aross apdulated and twisted, and beantifully fringed or laciniated. the colors vary from white to dark red. Price, per packet, 10 cents.

Double Annual Sweet Clove Pinks.

DOUBLE SNOWBALL. A beautiful variety with large pure white, double fiowers, rery full and deeply fringed, like fine Carnations. Price, 5 cents per packet.

DOUBLE IMPERIAL PINK. Tery double flowers, full and finely formed; a good range of colors, very bright and showy. Price, 5 cents per packet.

DOUBLE FIRE BALL. A beautiful double sort with fine flowers in rich shades of scarlet, running to crimson; striking in color. Piice, per packet, 5 cents.

NEW DOUBLE FRINGED PINK "EXCELSIS"(Double Dianthus Liciniatus Mirabilis, A new double. flowering Japanese Annual Pink. Price, per packet, 10 cents.

NEW DOUBLE ANNUAL PINK, COUNT KERCHOVE. Dew double annual Diadem Pink is sure to please. It produces magnificent large flowers in great profusion, of the richest glowing color. The petals are dark blood red, marked with a relerty-black spot. An exquisite flower for cutting. Price, per packet, 15 cents.

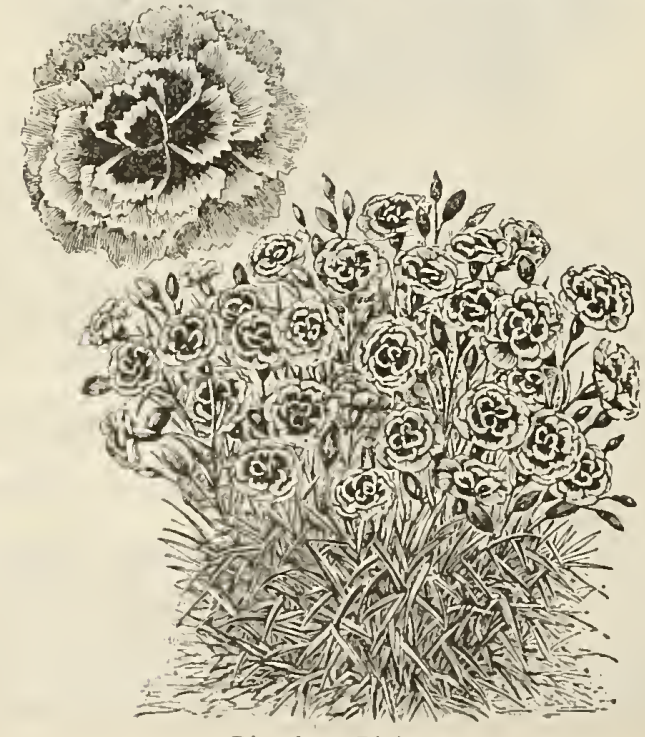

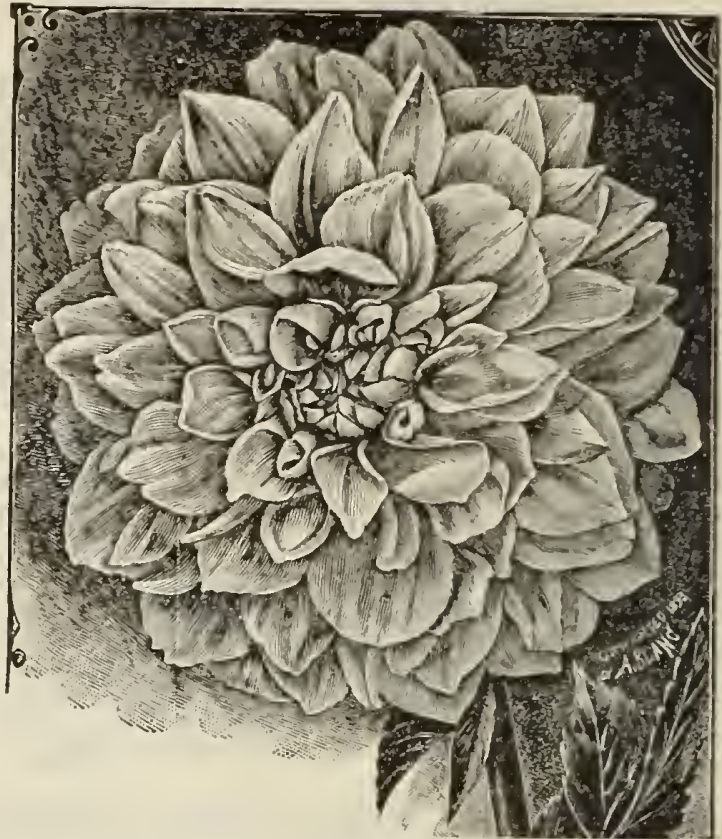

Dahlia

\section{DAHIIAS}

Dahlias are readily grown from seed, flowering freely the first season. Sow seed early in the spring in ricl soil in box, and keep in a sumny windour. Transplant io pots ond plant in the garden when trees are in full leaf. pots grow tall, tie the plants to stakes and trim off the side shoots to make the plants strong. Plant in a rich soil.

\section{Single Dahlias}

SINGLE GIANT PERFECTION. These single-flowered Dahlias are very large and perfect and are especially free bloomers. The colors are magnificent-White, cream-yel. low, salmon rose, searlet-crimson and deep maroon, many low, salmon rose, searlet-crimson and deep maroon, many of them with decided white disks
ter. Price, per packet, 10 cents.

SINGLE CACTAS MIXTURE. This trpe of Dahlia is now especially popular. The petals are curiously quilled, giring the flowers the look of Cactus blooms; all shades. Price, per packet, 10 cents.

SINGLE STRIPED AND SPOTTED. The flowers are very striking, being distinctly striped with bo:d splashes of contrasting color or thickly spotted with white or dark ground. Price, per packet, 5 cents.

\section{Double Dahlias}

PERFECTION POMPON. The flowers from this type of Dahlia are perfectly round and very double the petals in the center being very deep, giving it a very full form: colors are fine and the plants bloom rery freely Price, per packet, 10 cents.

DOUBLE CACTUS-FLOWERED. This is the most benuful class of Dahlias grown. The flowers are rery full perfectly double, and each petal bcing tubular end curiously rolled and twisted, gires them the unusual shapo of Cac tus bloons. The mixture contains a full assortment of colors. Price, per packet, 15 cents.

PREMIUM DOUBLE. This mixture is made from the largest-flowering double varieties and the colorings are magnificent; only the finest varieties are used in this mixture. Price, per packet, 15 cents.

DAHLIA, DOUBLE MIXED. Fine. Large flowering. Price, per packet, 10 cents.

\section{DOLICHOS}

\section{Hyacinth Bean}

A rapidgrowing annual clinber, flowering freely in clusters, followed by ornamental seed pods, for coverin arbors, trellises, etc. Sow the seed in the garden in April or May, where they are to remain; 10 feet.

DAYLIGHT, Purc white flowers, succeded by broad, white pods. Price, per packet, 10 cents. DARKNEsS. The flowers are larender-purple. Price,
per packet, 10 cents. 


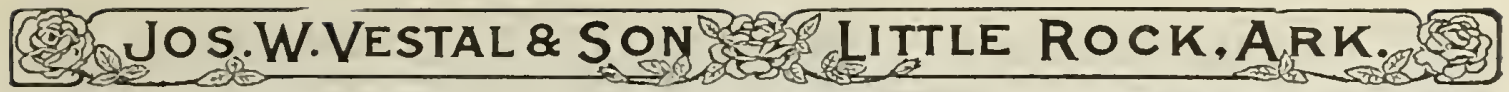

\section{DATURA}

(Trumpet Flower.)

Strougegrowing garden aunuals, three to four feet high, ith large, showy trumpet-slaned flowers.

CORNUCOPIA. ("Forn of Plenty.") A grand rariety. The flowers avernge eight inches long by fivc incles across, French white inside, purple outsicle; delightfully fragrant: Price, per packet. 10 cents

\section{BURBANK'S SHASTA DAISY}

In growith the plauts are as strong as a common field Doisy-very tall-well branched, with fine-cut foliage and huge white flowers, borne in profusion on long, stiff stenis. The flowers are pure white with gold center; petals rery long and center soft and velvety. When fully inches across. The bloams last a long timc on the plant, and nothing could be fincr for cut flowers.

Planted in the garden, the Slinsta Daisy will make n perfect sheet of dazzling white bloom, the flowers beiug so abuudant that the heads crowd closely together. Sow the seed in the garclen when the leaves are starting out on transplant. Price, per packet, 15 cents.

MARGUERITE DAISIES. The old faroritc variety of small white Marguerites. Price, per packet, 10 cents.

\section{ESCHSCHOLTZIA \\ (California Poppy.)}

Tery besutiful annuals of easy culture from seed sown early in the spring where plants are to remain.

Mixed. Flowers in all colors, resembling double Poppies. Price, per packet, 5 cents.

\section{BURBANK'S CARMINE KING.}

New Eschscholtzia or California Poppy.

A new and distinct color in this well-known annual. The color is such a surprise that it is hard to believe it to be a California Poppy. Mr. Burbank, the originator, says of it: My strain las been produced from one plant by most ricid stection from season to season, until now the fiowers are of a very clear carmine or rosy-crimson, freely produced. The plants grow about one foot high and a foot or more across, greatly admired by all who have seen them." Price, per packet, 15 cents.

\section{FEVERFEW}

A free-flowering plant growing eighteen inches high with fincly cut foliage branching in a tall obelisk form, each branch bearing many small, double white flowers about the size of a quarter.

GRANDIFLORA WHITE. This rariety bears quite large flowers and is very fine for cutting. Price, per packet, 10 cents.

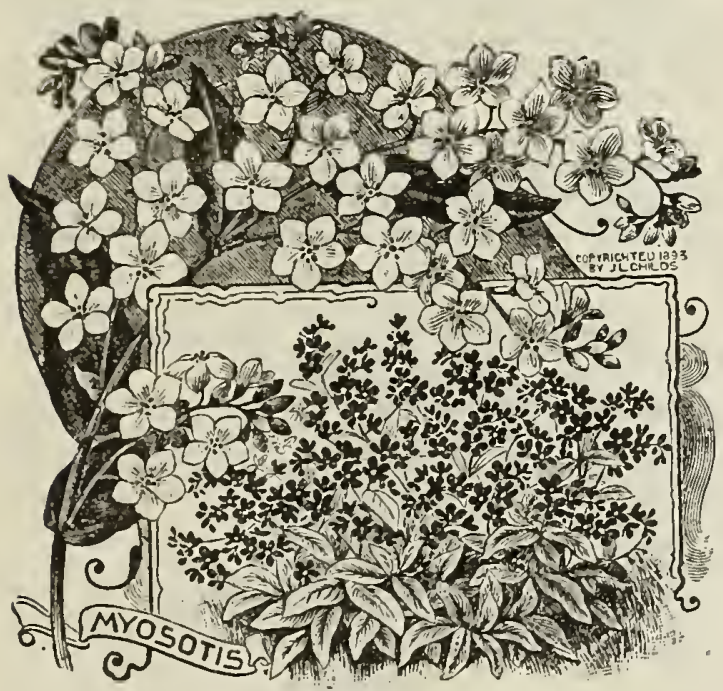

FORGET-ME-NOT

\section{Myosotis.}

A charming littlc plant, perfectly hardy and much priz. ed for its delicately colored flowers. Sow seed rerr early in spring, as soon as the ground can be worked, anc treat the same as a Pansy. New rarieties bloom the frst yenr and more profusely the second.

TURQUOISE. Large blooms in clear turquoise blue. Price, per packet, 10 cents.

MIXED COLORS. Containing white, pink, pale blue and deep blue. Price, per packet, 5 cents.

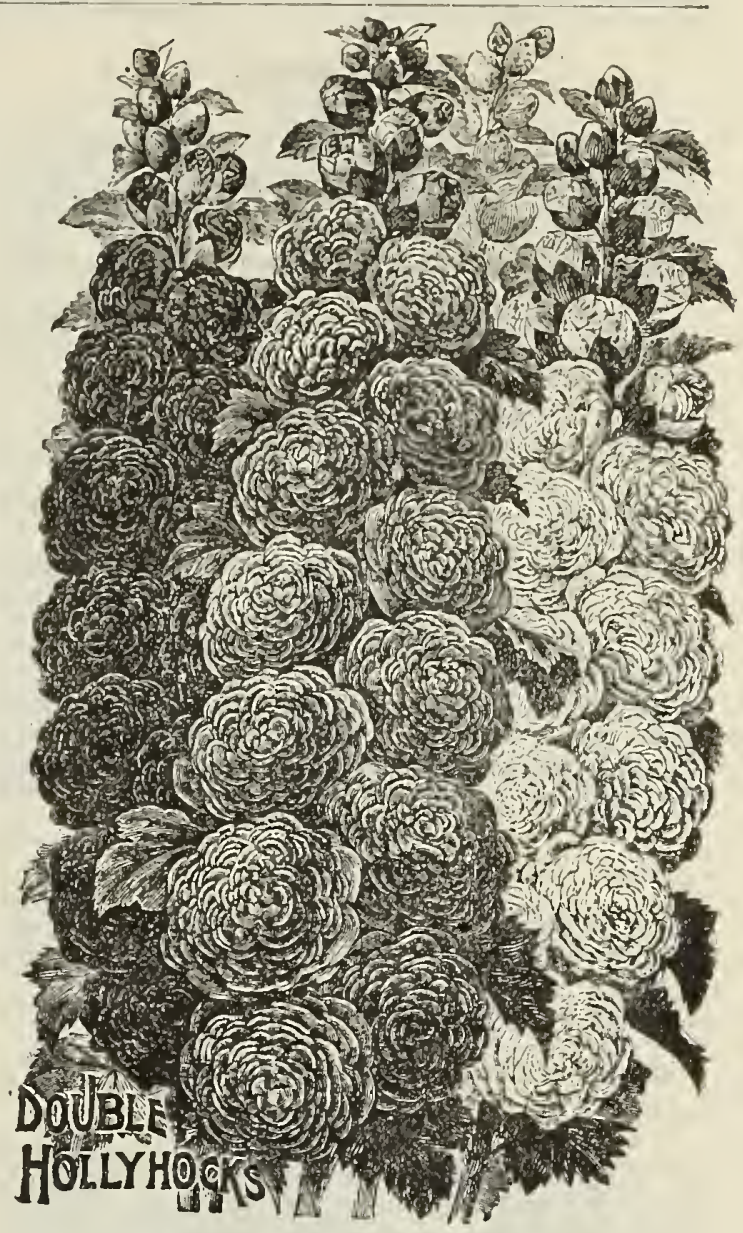

NEW ANNUAL HOLLYHOCKS

(Bloom from seed the first year.)

This new strain possesses the rirtue of the double old fashioned Hollyliock, with the additional adrantage of blooming from seed the first year. Plants started from seed sown in March or April, in the house or hotbed, transplanted in May in the permanent place, will bloom in August and continue until late in the fall. The plants are not easily attacked by the Hollyhock fungus. Flower are double, semi-double, or single. Price, per packet, 20 cents; three packets for 50 cents.

\section{FOUR O'CLOCK.}

(Marvel of Peru.)

Beautiful summer-blooming annuals of bushy habit, two feet high, each plant bearing throughout the sum mer hundreds of large flowers of white, yellow, crimson and striped.

MIXED COLORS. Price, per packet, 5 cents.

\section{GAILLARDIA}

(Blanket Flower.)

Very showy free flowering plants that are quite hardy and are very easily raised from seed. The flowers are of two types, double, wade of small florets and single, which are of large daisy form. Sow seed quite early in spring in shallow drills and thin out.

GAILLARDIA PICTA LORENZIANA. Double fiowers, in the gayest colors. Flower heads are round and beautifully formed Maroon, tipped with yellow and yellow and

GAILLARDIA GRANDIFLORA SINGLE. A mixture of the finest single varieties grown, many of them having beautifull $y^{\circ}$ marked petals in the most brilliant colors. Price, per packet, 5 cents.

\section{THE WONDER COLLECTION}

SIX PACKETS OF SEED FOR 10 CENTS. OUR SELECTION OF VARIETIES. In this collection, like all others the seed is fresh and true to name. The varieties selected from the most popular of the free. flowering annuals. We can only offer this collection at the price because it is made up of varieties we have an over-abundance of, and we therefore can give you this wonderful bargain for 10 cents. Try it Six packest of seed for 10 cents, our selection of varieties. 


\section{GYPSOPHILA}

\section{(Baby's Breath.)}

Dwarf branching plants of quick growth and great free dom of bloom. The flowers are small, starlike, and borne in feathery sprays which are highly esteemed for cut flowers, as thcy lend a most graceful effect when com bined in boqucts with Sweet Peas.

ELEGANS. White and rose, mixed. Price, per packet, 5 cents.

COVENT GARDEN. This is a greatly improved strain of Paniculata; the sprays can be cut with longer stems. Price, per packet, 5 cents.

\section{ORNAMENTAI GOURDS}

Fine clinbers, and especially interesting for children to plant.

NEST EGG. Oval white fruit like an egg. Price, per packet, 5 cents.

DISH RAG OR SPONGE GOURD (Chinese Luffa).

Yellow flowers followed by long green fruits, which form in seeds and shell are removed, is popular for bathing. Price, per packet, 5 cents.

SMALI, VARIETIES, MIXED. Gooseberry, apple, lemon, pear, shaped, etc. Price, per packet, 5 cents.

IARGE VARIETIES, MIXED. Dipper, sugar trough, club, bottle, etc. Price, per packet, 5 cents.

\section{GODETIA}

\section{(Satin Flower.)}

A most attractive bushy little plant with a host of bright flowers opening in the morning and closing at evening very efiective in gardens; not serviceable as cut flower height, 15 inches.

GLORIOSA. Blood red flower. Price, per packet, 10 cents.

CHOICE MIXED. Price, per packet, 5 cents.

\section{HELIOTROPE}

A well known and highly prized plant on account of A delightful fragrance of the flowers; excellent for pots, or for bedding; 18 inches.

CHOICE MIXED. Of many varieties. Price per packet, 10 cents.

\section{HIBISCUS}

(Marshmallow.)

CRIMSON EYE. Large white flowers with crimson center Flowers the first rear if sown early. Price, per packet, 10 cents.

\section{HYACINTH, OR JACK BEAN}

A rapid, compact growing vine, bearing a profusion of flowers, in clusters - white, pink, purple, etc.

MIXED COLORS. Price, per packet, 5 cents

JAPANESE VARIEGATED HOP

A splendid strong growing climber that is very showy on verandas. Leaves variegated green and white, strongly marked and shaped like maple leaves. Price, per packet, 5 cents.

\section{KOCHIA SCOPARIA}

(Summer Cypress or Mexican Burning Bush.)

This is a newly introduced plant which has become very popular and fashionable the past summer, being used extensively for hedges, borders to Canna beds, etc. I grows quickly from seed in the open ground. The plants should be thinned out to stand twelve or fifteen inches apart as they form a complete globe of thread-like light green stems and leaves. Early in the fall the whole bush turns a brilliant crimson, and is covered with tiny crimson star flowers. Very fine. Price, per packet, 10 cents.

\section{KUDZU VINE}

\section{(Peraria Thunbergiana.)}

This splendid hardy Japanese vine is the most rapid growing climber known. It has a tuberous root which is perfectly hardy everywhere, and in the spring sends up vigorous shoots which will quickly shade an entire piazza front; will grow 50 feet the first summer from seed sown in the open ground in May. Has large thick foliage and bears elegant clusters of pretty rosy-purple, pea shaped blossoms and unequalled for making a quick and durable shade. Price, per packet, 10 cents.

\section{IANTANA}

Well-knnwn slurubly phants, with elusters of rerbena.like flowers, mate a urand display the first season. In ful flowers all suminer; much admired.

HYBRIDA MIXED. This mixture is coinposed of the tall growing varieties and will flower in all the shades -yellow, orange, mandarin, scarlet and rose. Yery profuse blosmers. Price, per racket, 5 cents,

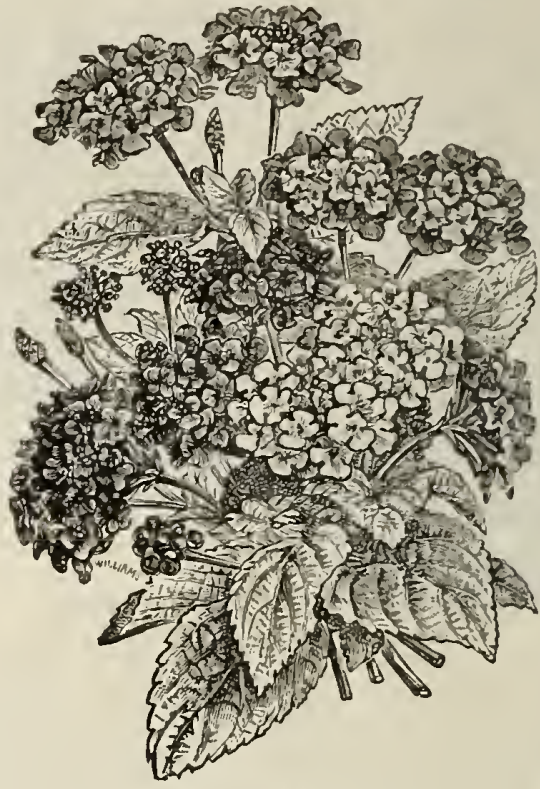

Lantana

\section{LAVENDER}

An annual bearing a very fragrant flower, used to lay among clothing to impart its sweetness. Every woman should have a few plants in her garden. Price, per packet, 5 cents.

\section{LOVE IN A MIST} (Nigella.)

Compact, free-flowering plant, with finely cut foliage, curious looking flowers and seed pods; of easy culture, growing in any garden soil; hardy annuals; one foot.

MIXED VARIETIES. All colors. Price, per packet, 5 cents.

\section{IINUI \\ (Flax.)}

COCCINEUM. (Scarlet Flax.) One of the most effective and showy bedding plants; of long duration having fine foliage and delicate stems, with brilliant scarlet-crimson flowers; hardy annual. Price, per packet, 5 cents.

\section{LARKSPUR}

A quick-growing, free-flowering annual, with fine feathery foliage and tall spikes of odd-shaped flowers in purple, blue, pink, rose and white. Sow seed quite early in the spring and thin out.

CANDELAZRUM MIXED. A class of Larkspurs which throw out branches, each branch bearing a spike of bloom much as a candle is held in a candelabra. The plants are dwarf and compact and flower in all shades of purple, blue, maroon, pink and rose. Price, per packet 10 cents.

GIANT HYACINTH FLOWERED. New from Germany. Mixed, all colors. Price, per packet, 10 cents.

DOUBLE TALL STOCK FIOWERED. Spikes of double flowers eighteen inches long; rery benutiful. Several of the brightest and best colors. Price, per packet, 10 cents.

\section{IOBELIA}

Splendid bushy little plants, with fine foliage and masses of bright, wing-shaped flowers. They are of two types, the weeping and the compact growth. The weep ing is fine for hanging baskets and window boxes, and the compact is excellent for bordering flowerbeds. The smallest plants are covered with bloom so that the folinge is scarcely noticed. The color of the flowers is from deep indigo blue to white.

LOBELIA COMPACTA. Fine mixed, all colors. Bush form for border. Price, per packet, 5 cents.

LOBELIA GRACILUUS. Fine mixed, all colors. Fine vine for hanging baskets or vases. Price, per packet, 


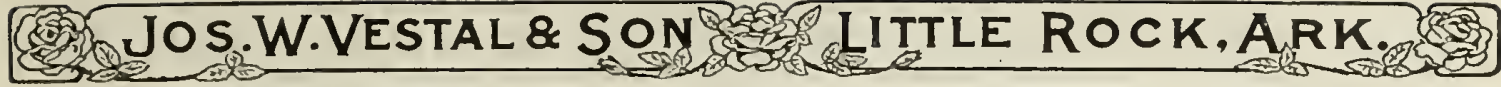

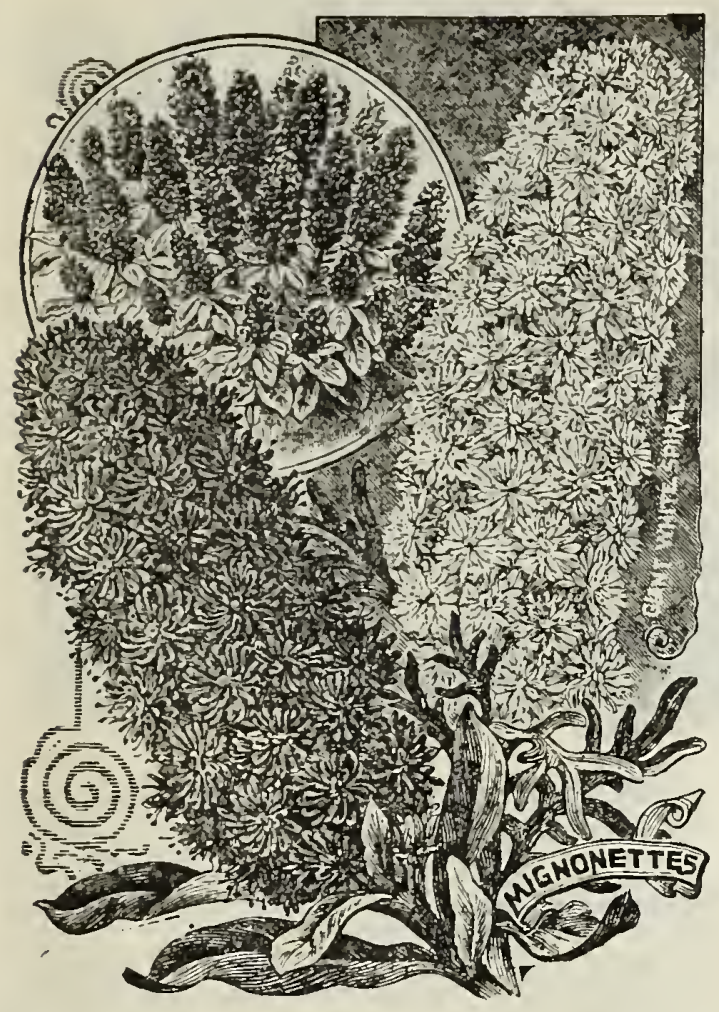

\section{MIGNONETTF}

Quick growing plants, grown for their delicious fragrance. Sow early in the spring in the garden where the plants are to remain. But for winter flowering sow in August and pot before frost.

SWEET MIGNONETTE. (Reseda Odorata.) The good, old-fashioned, sweet Mignonette. Price, per package, 5 cents.

MIGNONETTE MATCHET. Stout flower stalks, bearing massive spikes of deliciously scented red flowers. Price, per packet, 10 cents.

\section{NEW GIANT MIGNONETTE, RED GOLIATH}

This new variety is claimed by experts to be the most berutiful Mignonette in existence. Plants of compact habit; giant trusses of flowers, surpassing all others in brilliancy of color, which is decidedly red in effect; fragrance deliciously rich. Price, per packet, 15 cents.

\section{NEW GIANT WHITE MIGNONETTE WHITE PEARI}

This variety is of strong, robust growth, producing in great abundance large conical heads of pure white flowers of exquisite fragrance. Price per packet, 10 cents.

\section{MIMULUS}

(Monkey Flower.)

Admirable pot plants, and equally adapted for the garden. The color and markings of the large Gloxiniashaped flowers are rich in the extreme, ranging through crimson, maroon, yellow, white and pink, beautifully spott. ed and bloched.

FINE MIXED. Price, per packet, 5 cents.

\section{MUSK}

A small plant easily orown whose leaves are used as a perfume. Price, per packet, 5 cents.

\section{MIMOSA PUDICA \\ (Sensitive Plant.)}

Curious annual; the leaves instantly close up when touched. A neat plant for either pot or garden culture. Two feet. Price, per packet, 5 cents.

\section{MOONFLOWERS}

(Ipomcas.)

TRUE WHITE MOONFLOWER. Fine strong.growing climbers that will reach a hcight of twenty feet in one season. Foliage is large and very dense, making a fine shade for porches plant seeds in rich soil in spring where vines are to grow. Immense, pure white, sweetscented flowers, measuring from four to six inches across and borne in clusters. Price, per packet, 10 cents.

HEAVENLY BLUE MOONFLOWER. Immense flowers of pale sky-blue of an cxquisite shade; very beautiful, es pecially when planted with White or True Blue. Price. per packet, 10 cents.

SCARLET STAR. This is a very beautiful climber, bearing star-shaped clear scarlet flowers in clusters very profusely; vine is a splendid grower, and is fine to use among the blue and white flowered varieties. Price, per packet, 5 cents.

\section{JAPANESE IMPERIAI} Giant Morning Glories.

Wherever climbers can be grown these should have a prominent place. They are beyond question the liand. somest of all Morning Glories. Of the easiest culture: can be sown in the open ground in a warm and settled climate. The foliage is luxuriant, distinct and varied, green silvery and yellow leaves; many are mottled light and dark oreen, white and rray. The giant flowers are beyond description; the self or solid colors range from snow-white to black-purple, an endless number having flowers spotted, marbled, striped, flaked, splashed, etc.

IMPERIAI JAPANESE MIXED. Price, per packet, 10 cents.

\section{NEW SEMI-DOUBLE JAPANESE MORNING GLORIES}

Though not really double the flowers often appear like one blossom thrust within another, the inner one being crinkled and cut Very attractive. Many colors mixed. Price, per packet, 15 cents.

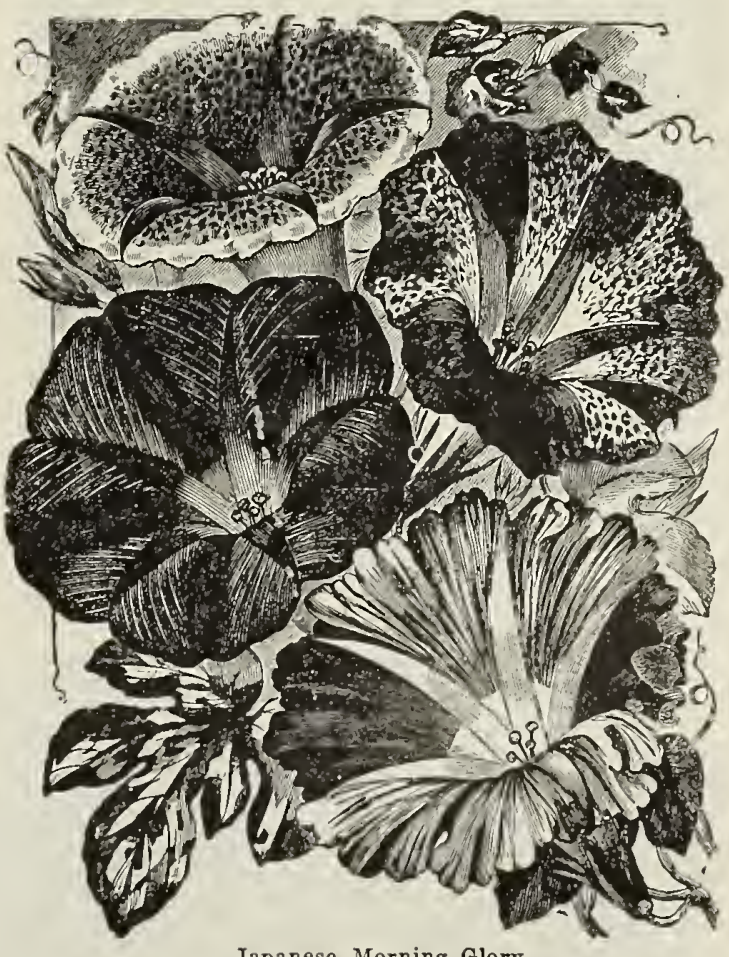

BRAZILIAN MORNING GLORIES

A very rampant grower, the stems and under sides of the leaves being thickly covered with soft reddish hairs. The flowers are of very satiny texture of a beautiful redviolet shade. A splendid sort. Leaves gigantic and flowers equally so. The best vine known to cover a large space quickly. Price, per packet, 10 cents. 


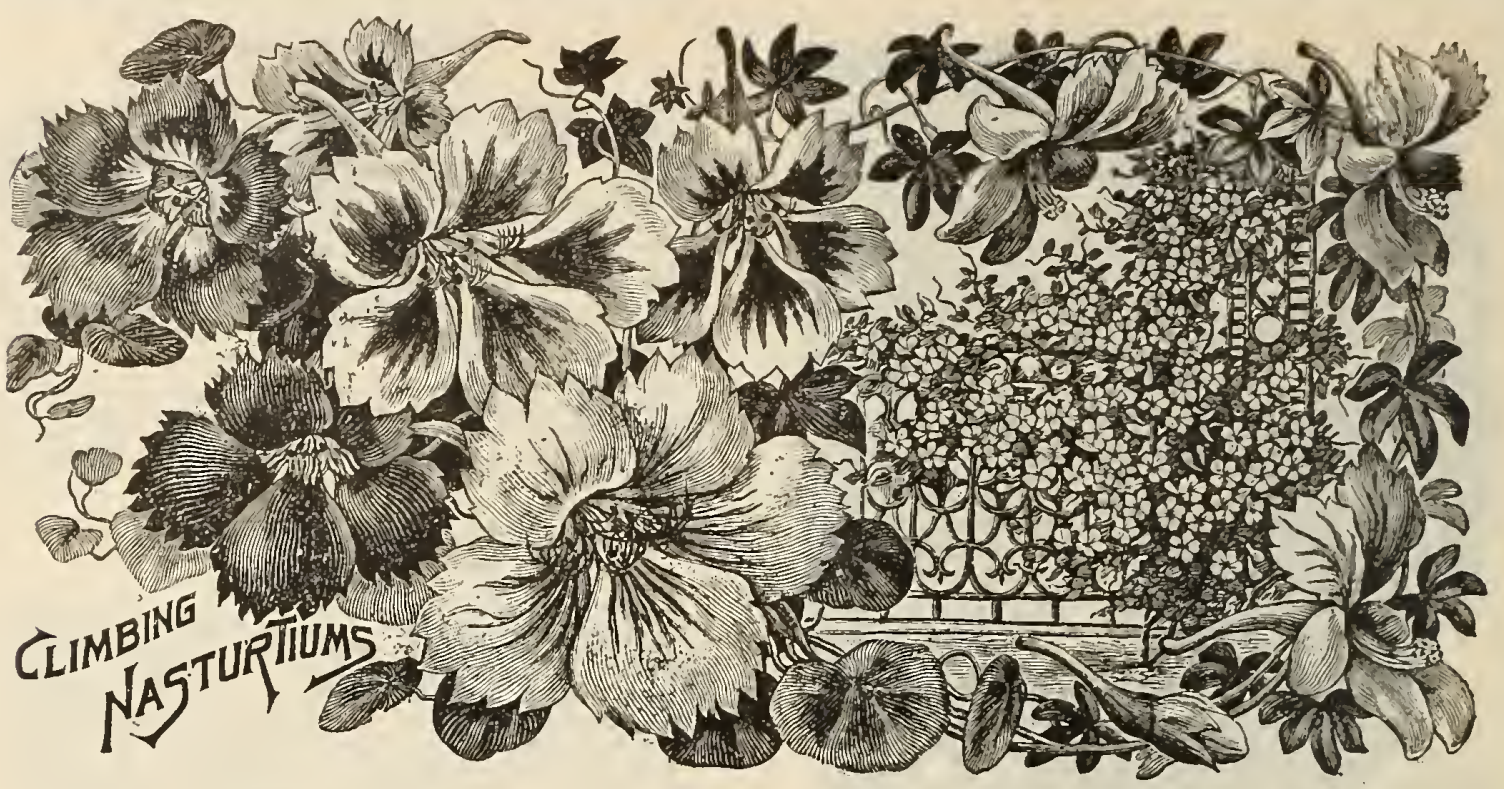

\section{NASTURTIUMS}

Few flowers impart such rich "bits of beauty" to the garden as the different types of Nasturtiums. In addition to their use in the garden and on trellises, we would etc., or wherever it is desired to have bright colors in profusion.

\section{SELECT GIANT FLOWERED TALL NASTURTIUMS}

BUTTERFLY. The flowers are very large, measuring three inches across and have a crepe like texture. The color is a light lemon yellow, marked on the lower petals with a blotch of ricl terra cotta l'ed. The two upper petals marked bright red. Price, per packet, 10 cents; per ounce, 30 cents.

CAPRICE. Beautifully mottled and blotched fiowers large and brilliant. An interesting and charming variety. Price, per packet, 10 cents; per ounce, 30 cents.

CHAMELON. Flowers of various colors. On the same plant are found self colored flowers, some curiously stain ed, while others are banded with light or dark shades. Price, per packet, 5 cents; per ounce, 20 cents.

DARK CRIMSON. Deep velvety red. brown and brown ish crimson. Price, per packet, 5 cents; per ounce, 20 cents.

FLAMMEUM. A heavy rich scarlet flower with brown markings and shadings. Price, per packet, 5 cents; per ounce, 20 cents.

FASHION. The flowers are truly gigantic in size and an entirely new color in Nasturtiums. A pure ecru, over laid with a deep veining of old rose. Price, per packet, 10 cents; per ounce, 30 cents.

HOT SPUR OR RED SPUR. Some are deep orange, spotted with blood red, others with creamy white, bloched with orange-scarlet, while they are also bright flowers of brilliant red splashed with yellow. Each with a red spur: dark colored handsome foliage. Price, per packet, 10 cents; per ounce, 30 cents.

KING THEODORE. The deepest crimson variety.

Flowers very rich, like thick red velvet. Price, per packet, 5 cents; per ounce, 20 cents.

SALMON QUEEN. A magnificent variety with dark SAl solvety shade of salmon. Price, per packet, 5 cents, per ounce, 20 cents.

SUNLIGHT. Flowers large and crepe-like in form Color a clear, beautiful yellow. Solid color with no mark ings. Price, per packet, 5 cents; per ounce, 20 cents.

TWILIGHT. The flowers are extra large and full expanded form. Color faint salmon or buff tint, heavily suf fused with a rosy-salmon. The three upper petals are beautifully veined with crimson. Price, per packet, 10 cents; per ounce, 30 cents.

MOONLIGHT. Pale straw-colored flowers with large, crepe-like petals, very delicate and beautiful. The flowers are of unusual size. Price, per packet, 5 cents; per ounce, 20 cents.

MIDNIGHT. Plants of extreme dark green foliage. The flowers are a deep brownish-red or crimson, shaded darker. Petals like crumpled relvet. Price, per packet, 10 cents; per ounce, 30 cents.

\section{TOM THUMB OR DWARF NASTURTIUMS}

These are of dwarf, compact, rounded growth. Fine for borders or mixed with foliage plants in ribbon beds. As with all Nasturtiums, they succeed best on light, well-drained soils or in slightly raised beds where any surplus mois. ture will rapidly drain away.

KING. Dark foliage and flowers of a rich relvety crimson. Price, per packet, 5 cents; per ounce, 15 cents.

VESUVIUS. Dwarf, compact, neatly rounded bush, growth eight to ten inches ligh with small dark-green leaves. The flowers are large, of fine form. The broar petals are salmon-orange, flushed and striped with brownish-red. Price, per packet, 5 cents; per ounce, 20 cents.

QUEEN OF TOM THUMBS. The light green leave: grow so closely together as to overlap each other, and each leaf is showily variegated or marbled with silvery. white. They produce rather small but ricb purplish-crim. son flowers. Price, per packet, 10 cents; per ounce, 30 cents.

NEW DWARF GOLDEN MIDNIGHT, nne of the most heautiful novelties yet produced. The contrast between the clear golden yellow foliage and extrenely dark flower is most remarkable. The foliage is liglit yellow while the flowers are such intensely deep maroon as to seem almost black-hence the name "Golden Midniglit." "Price, per packet, 5 cents; per ounce, 20 cents.

CARMINE KING. Dark foliage, rich relerty carmine flowers produced profusely. Price, per packet, 5 cents; per ounce, 20 cents,

PRINCE HENRY. Straw yellow, heavily suffused with rose, one of the most distinct and charming. Price, per packet, 5 cents; per ounce, 20 cents.

PEARL. Clear lemon yellow shading to faint primrose. Price, per packet, 5 cents; per ounce, 20 cent 3.

NEW FRENCH CHAMELEON. Flowers of most diversified coloring and many brilliant markings on a single plant. Plice, per packet, 5 cents; per ounce, 20 cents.

IVY-I.EAVED NEW DWARF MIXED, "Brilliant Beauties." The plants are of strong rigorous growtl : the leaves on different plants range from pale green to a rich purplish tint; they begin to bloom quite early in the summer and continue to flower profusely until frost. The fiowers are wonderfully brilliant. In some flowers the texture is that of delicate silk or crepe, others have the gloss of satin, and still others are of rich relrety $a p$. pearance. Price, per packet, 15 cents; per ounce, 30 cents.

\section{SPECIAL MIXTURE OF DWARF NASTURTIUMS}

This mixture contains eighteen different varieties of Dwarf, of "Tom Thumb" Nasturtiums. Their handsome foliage shows a variety of green shades, including both light and very dark blue green leaves with distinct veins, as well as the old well known tints: and the flowers are also greatly improved in coloring and in marking. Both also greatly improved in coloring and in marking. Both this mixture and the Special lixture of new to the species, and some showing odd colors heretofore unknown. Price, per packet, 10 cents; per ounce, 20 cents. 


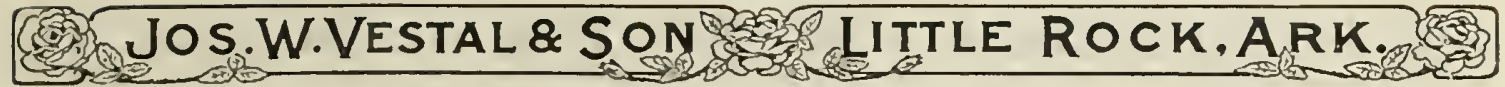

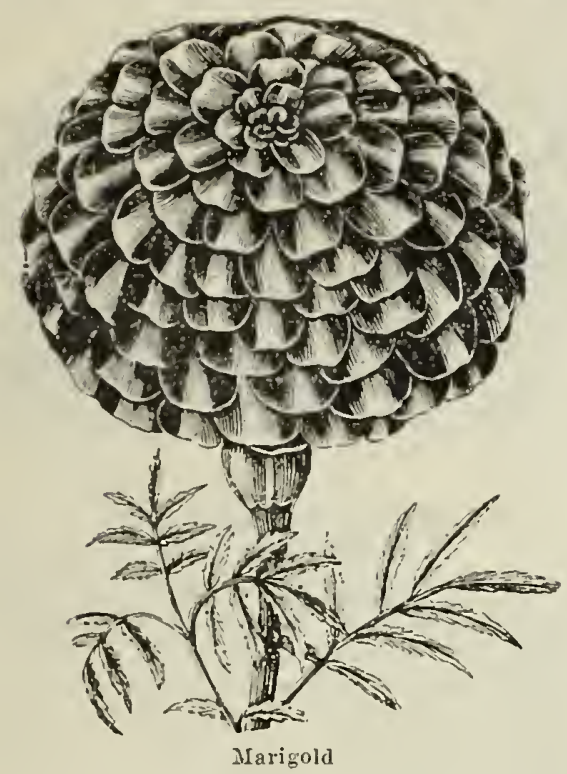

MARIGOLD

4 swift-growing annual that will make a great show of flowers of all shades of yellow, orange, red and copper, for little care and small expense.

\section{AFRICAN MARIGOLD}

ORANGE PRINCE. Immense double flowers of bright rich orange color; very fine. Price, per packet, 10 cents|

LEMON QUEEN. Large, very double flowers of light lemon-yellow: a new and rery fine rariety. Price, per packet, 10 cents.

AFRICAN MIXED. All colors. Price, per packet, 5 cents.

\section{FRFNCH MARIGOLD}

GOLD STRIPED. Beautiful coloring. Price, per packet, 5 cents.

DWARF FRENCH MIXED. Many colors, Price, per packet, 5 cents.

\section{NICOTIANA SANDERAF}

New Carmine Tuberose-Flowered Tobacco.

A new rariety of great merit, growing about two feet high; flowers of the most handsome carmine-red color; rery fragrant; harly annual, easily grown. Price, per packet,

\section{PORTULACA}

(Sun Plant.)

One of our finest annual plants, of easy culture, thriving best in a rich, light sandy soil, sunny situation Flotvers are the form of small roses, and come in rellow, scarlet. white, crimson, rose orange-rery brilliant.

SINGLE MIXED. All colors profuse bloomers. Price, per packet, 5 cents.

DOUBLE MIXED. Flowers perfectly double, of the most brilliant scarlet, crimson, white, pink. rose, yellow and orange. Very fine for bedding. Price, per packet, 10 cents.

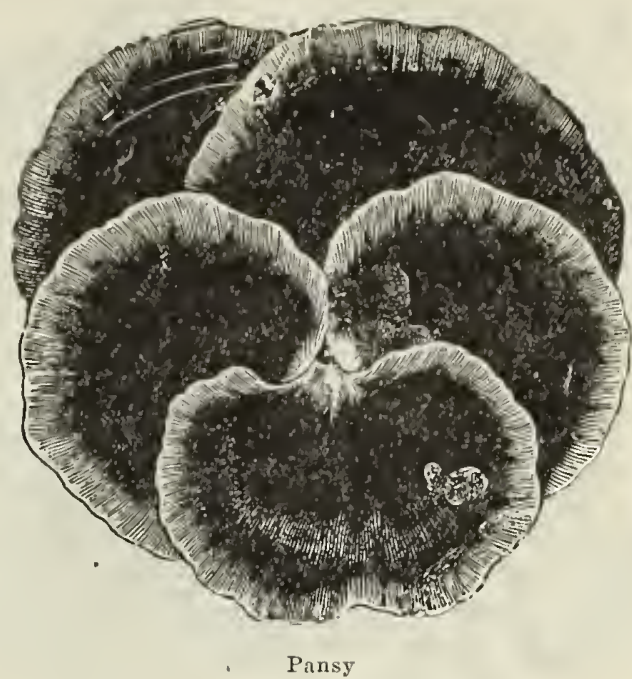

PANSIES

FINE MIXTURE OF GIANT PANSIES. (Maxima Mixture.) In this we offer you the finest mixture of pansies ret produced. The flowers are all giant, exquisitely veined, shaded and bloched, embracing all the colors known in Pansies and many new shades just produced by the European growers. The variety is endless, so that in a large hed no two plants have flowers alike. Price, per packet, 25 cents.

GIANT GERMANIA, MASTERPIECE CURLED. This strain comes nearer to "Double Pansies" than any thing ever introduced under that name. Petals are crimpled and curled in such a fashion that the flowers appear double. Flowers are often three inches across, and the colors are odd and striking. Price, per packet, 20 cents.

GIANT FRENCH PANSIES, PARISIAN STAINED. The Parisian Pansies are distinguished by their magnificent and varied colors and strong markings. There is usually a large "blotch" on each of the five petals, with a sur. rounding band of some strikingly contrasting color, over all of which is thrown a cobweb-like netting of yet another hue. Flowers mammoth, Price, per packet, 20 cents.

NEW ENGLISH PANSIES, ENGLISH PRIZE. The pansy is continually being improved, and English German and French seedsmen are constantly vying with each other to produce the finest. This mixture is saved from the finest prize collection of Pansies in England. The size of flowers and brilliancy of coloring cannot be described. None are finer. Price, per packet, 25 cents.

NEW MAMMOTH MIXTURE. Our own mixture of the best varieties, and in it you will find every color, in flowers of good size and most prolific in bloom. Each year this mixture is improved by having newer imported varieties added. Price, per packet, 10 cents.

THE INTERNATIONAL PANSY COLLECTION. One packet each of Maxima Masterpiece, Parisian Stained and English Prize, for 75 cents. Over 1000 seeds of the finest Pansies known.

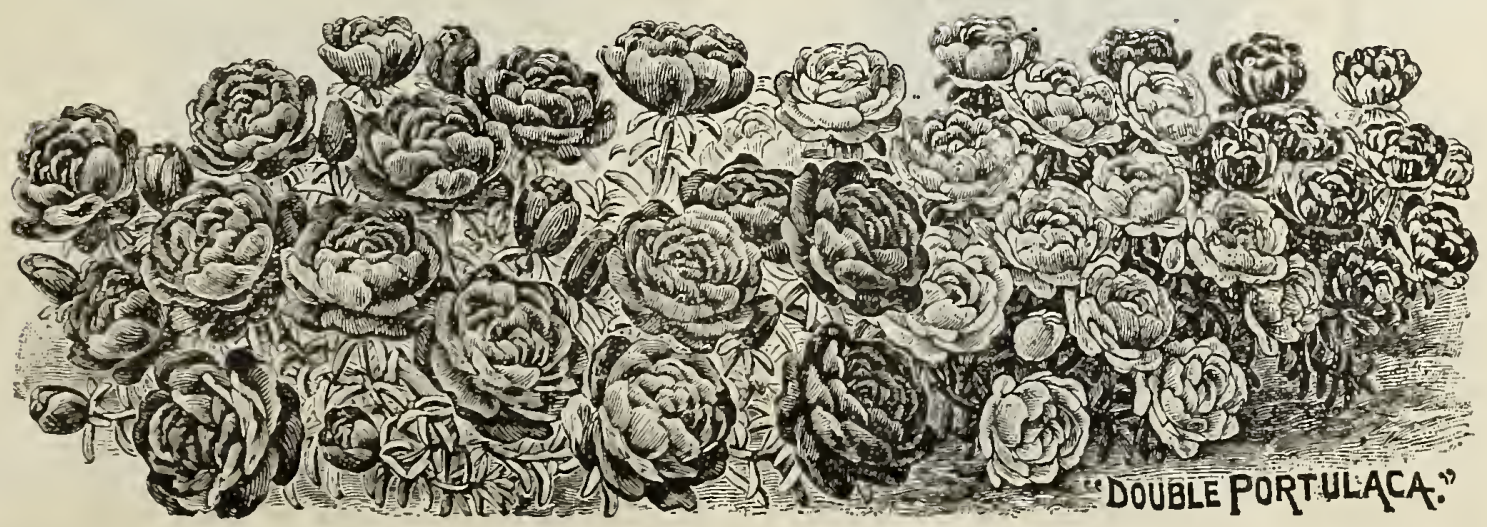




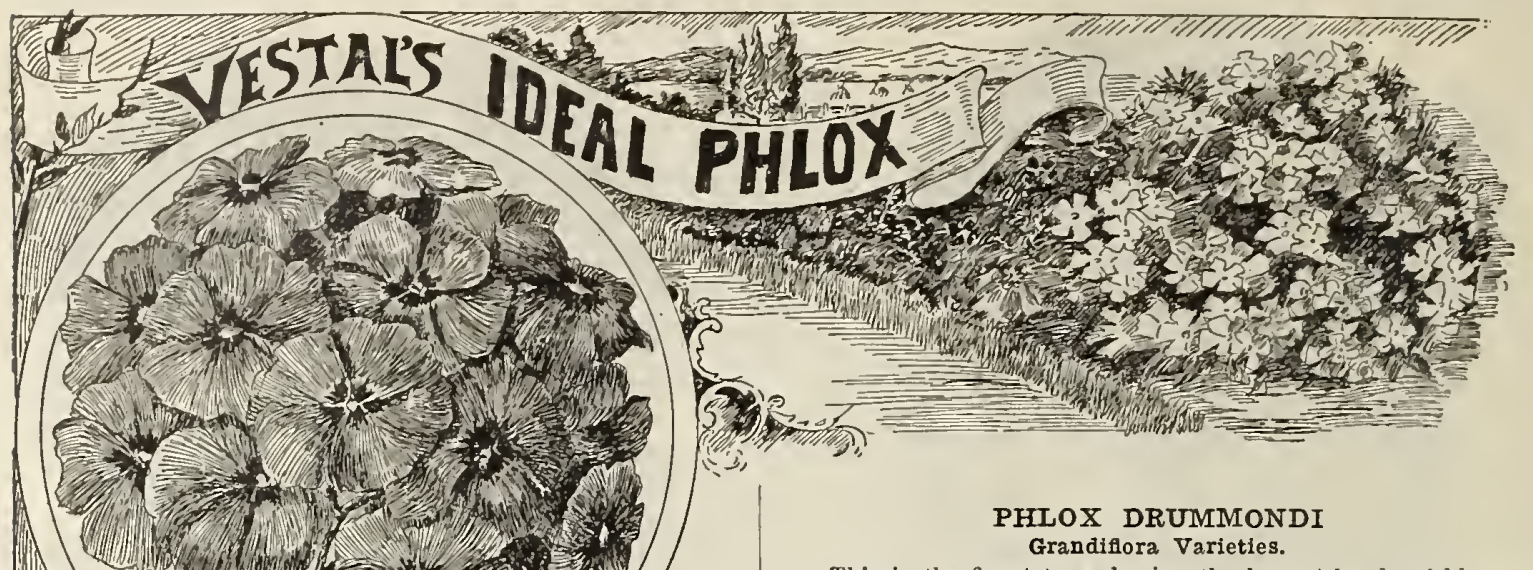

This is the finest type, haying the largest heads of bloom as well as the largest individual flowers. Price, per packet, 10 cents; two packets, 15 cents; five packets, 30 cents.

CARNEA. Delicate rosy-flesh color.

SNOWSTORM. Large flowering, pure white.

GLOWING CRIMSON. Beautiful shade of brilliant crimson.

BRILIIANT ROSE. A true bright pink.

COCCINEA. Bright scarlet.

GOLDEN GLOW. Beautiful rich yellow.

VIOLET. Dark violet or purple.

NEW PHLOX "SALMON STAR-EYED" (Salmanea

A very beautiful flowering vine, easily raised from seed. Flowers are most intricate in form, either white, blue, pur ple or crimson, tinged with green on the under side. Price, per packet, 10 cents.

\section{PYRETHRUM}

Foliage plants used for edging of ornamental beds: leaves are finely cut and of a golden yellow color.

AUREUM. (Golden Feather.) Bright golden foliage. Price, per packet, 10 cents.

SELAGINOIDES. Leaves very finely cut. Price, per packet, 10 cents.

\section{PLATYCODON}

(Hardy Chinese Bell Flower.)

A beautiful class of hardy plants, producing showy flowers throughout the summer. They form large clumps and are fine for planting among hardy shrubs. The flowers are very large, bell-shaped, and come in rich shades of dark blue, light blue, violet and white.

GRANDIFLORA MIXED. Fine shades of blue and white. Very large flowering. Price, per packet, 5 cents.

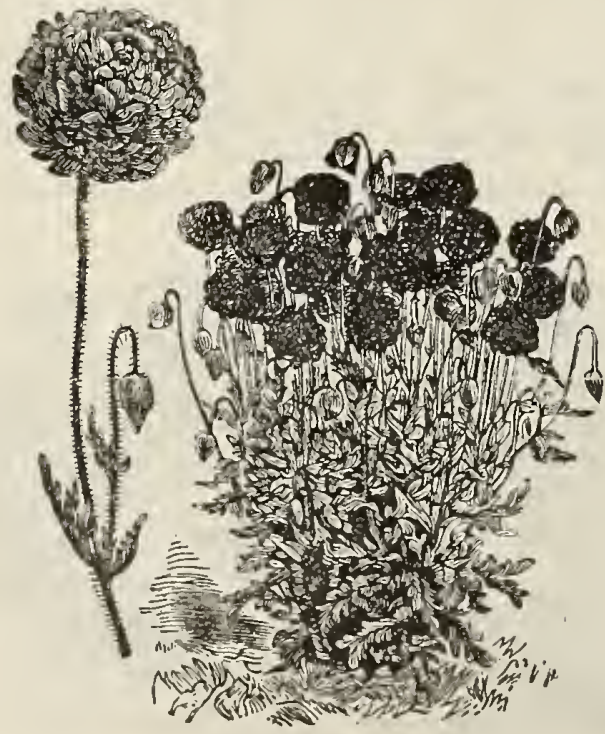

Poppy
Stell versally liked for their vigorous growth and abundant blooms. The flowers borne in immense trusses are unusually large and of a most pleasing rosy-salmon with a clear white eye. Price, per packet, 15 cents.

STAR-EYED (Stellatas), mixed colors. Grand large flowers, beautiful colors, each flower having a white star eye. Price, per packet, 10 cents.

STRIPED MIXED. Pure white, with brilliant colored stripes. Price, per packet, 10 cents.

STARRED AND FRINGED PHLOX. MOst distinct and striking. The flowers have a star-like appearance, white margins border the edges of the petals. Price, per packet, 10 cents.

\section{PHLOX GRANDIFLORA MIXED}

We believe the Grandiflora Mixed Phlox to be the grandest strain ever introduced. Its habit of growth is neat and compact : the flowers are of uniform size and are produced in the oreatest profusinn. The colors embraced in this mixture show a wonderful dirersity, comprising twenty-eight distinct shades and markings. Price, per packet, 5 cents; seven packets for 25 cents.

\section{POPPIES}

SNOWDRIFT, Beautiful heads of snowy white flowers. Price, per packet, 5 cents.

FAIRY BLUSH. New variety; delicate blush color. Price, per packet, 5 cents.

GOLDEN GATE. Large flowers of every conceivable form and color. Price, per packet, 5 cents.

NEW CARDINAL. Fnormous; double; cardinal-scarlet flowers. Price, per packet, 10 cents.

SHIRLEY MIXED. Double and single flowers, fre. quently measuring over four inches in diameter; all colors. Price, per packet, 5 cents.

IMPROVED DOUBIE CARNATION MIXED, An im. proved stain, embracing a wide diversity of distinct shades and colors. Exceedingly double, with beautifully fringed petals. Price, per packet, 5 cents.

PAEONY FLOWERED MIXED. Immense double flowers, resembling a peaony. Price, per packet, 5 cents.

THE SET OF SEVEN POPPIES FOR 25 CENTS.

\section{HARDY PERENNIAL POPPIES}

GIANT ORIENTAI POPPIES. A charmin summerflowering plant, producing numerous leafy stems about two and a half feet high, with deep crimson flowers, having a conspicnous black blotch on each petal. This is one of the most showy and useful of this interesting and popular family. Price, per packet, 10 cents.

ICELAND POPPIES. They are perfectly hardy and produce an endless profusion of flowers. They are of a very graceful neat habit, with bright green, fern-like foliage, formed in tufts, from which issue slender stalks about twelve inches in hight, surmounted by yellow, white or orange-scarlet flowers. Price, per packet, 5 cents. 


\section{PETUNIAS.}

Petunias grow readily from seed, sown thinly, and lightly covered early in the spring when trees are starting out in leat. They are exceedingly easy to grow, are always cov. ered with bloom and are fine for bedding, window boxes and vases.

DOUBLE PETUNIAS. Seed of the double varieties of Petunias is very hard to obtain. We have secured some fone imported seed which will produce a large percentage of double.flowers of the largest varieties in bright colors and tints. Price, per packet, 25 cents.

\section{NEW GIANT FRINGED PETUNIAS}

GIANT FRINGED SCARLET, MRANDA. This is a rery beautiful and rare Petunia, as it is a solid colored flower of brilliant scarlet with a fringed edge of delicate rose. The blossoms are immense and of surprisingly rich coloring. Price, per packet, 20 cents.

GIANT FRINGED MHXED. Flowers rery large, in great variety of color and with deeply fringed and ruffled edges. Price, per packet, 15 cents.

\section{SINGLE PETUNIAS.}

BLOTCHED AND STRIPED. A fine strain, producing a great profusion of crimson and white flowers beautifully blotched, striped and marked. Flowers very large. Price, per packet, 10 cents.

VENOSA, OR VEINED VARIETIES. Flowers of delicate shade of pink and white, veined from the throat to the edge of the petals with wavy lines of dark crimson. Price, per packet, 10 cents.

FANCY STAR. A beautiful new strain of Petunias of which bloom in all shades of rose, crimson and magenta, strikingly marked with a bold, clear-cut white star. Price, per packet, 10 cents.

COUNTESS OF ELLSMERE. A beautiful flower not so large as the giant.flowered sorts, but of a most exquisite color, pure glistening pink like a La France Rose, with white throat. Price, per packet, 10 cents.

PURE WHITE. Fine, pure white flowers, profuse bloom. ers. Price, per packet, 10 cents.

\section{PENNESETUM RUEPPELIANUM (Purple Fountain Grass.)}

A beautiful annual ornamental grass, growing about two and one-half feet high, producing long, graceful cylindrical, purplish plumes. An excellent ornamental plant for all bedding purposes and the most appropriate we know of to use as an edging to a bed of Cannas. Price, per packet, 5 cents.

\section{PENNESETUM LONGISTYLUM} (Silver Plume Grass.)

Like the Purple Fountain Grass, with the exception of the plumes, which are of glistening silver-white. Price, per packet, 5 cents.

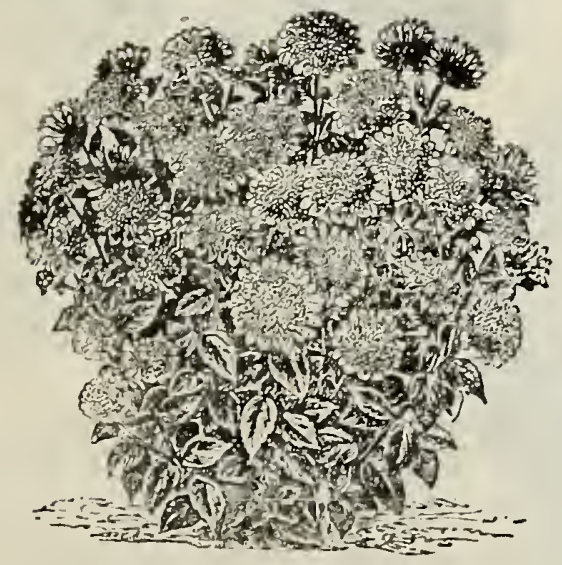

Sunflower

\section{PACKET DISCOUNT}

We sell six 5 cent packets of seeds for 25 cents. Thirteen 5 cent packets for 50 cents. Ten cent packets count as two 5 cent packets. We pay postage, thus our seed store is practically at your own door.

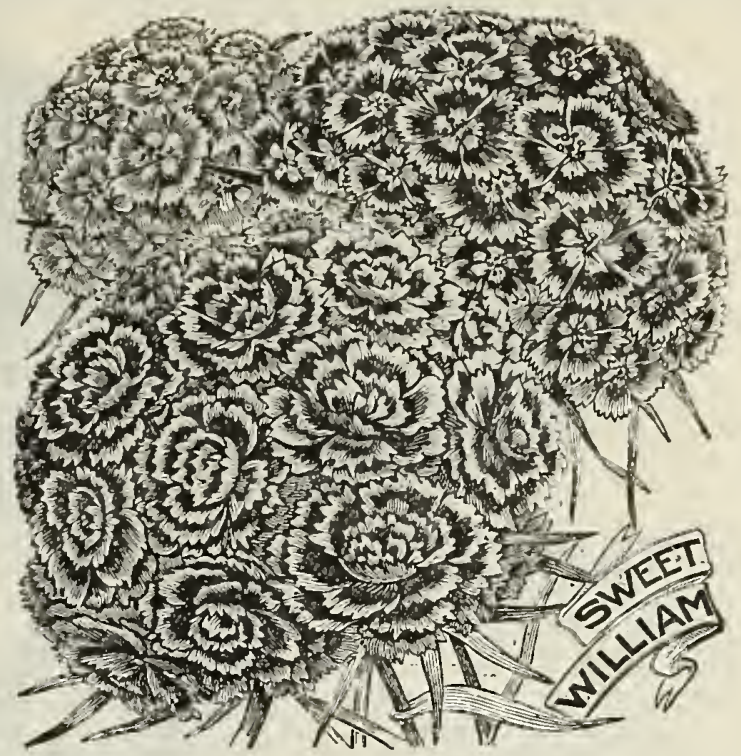

SWEET WILLIAM

(Dianthus Barbatus.)

A very beautiful class of plants of extreme richness and diversity of color. They have greatly improved of late years. One and one-half feet, hardy, perennial. DOUBLE MIDNIGHT MIXTURE. A mixture of the darkest, richest crimson shades, very beautiful, and splendid bloomers. Price, per packet, 10 cents.

DOUBLE GRANDIFLORA MIXED. Fine mixture of all shades and color from white to deepest crimson, very double. Price, per packet, 10 cents.

SINGLE MIXED. All shades of fine single varieties. Price, per packet, 5 cents.

\section{SUNFLOWERS}

Splendid for massing at the back of garden, where tall plants are needed. Sunflowers now come in a great number of varieties and many of them are very beautiful for cutting.

ORION. A new variety of Sunflower which resemble very much the handsome Cacti Dahlias. The petals are crisped or quilled, making it a fine variety for cutting. Price, per packet, 10 cents.

RUSSIA GIANT. Enormous, very double fiowers of a deep golden yellow. The petals are fine, and set so closely together it resembles a thick golden plush. Price, per packet, 5 cents.

DOUBLE MINIATURE. Produces short plants with hundreds of perfectly round, extra double flowers, pom pon shaped. Price, per packet, 5 cents.

VESTAL'S MIXTURE. In this mixture are double and single, tall and dwarf, and all shades of color. Price, per packet, 5 cents.

NEW DOUBLE CHRYSANTHEMUM-FLOWERED SUNFLowER, Grows seven feet high; perfectly double; the color is the brightest golden-yellow: the flowers are so perfect in form that they resemble very double Chrysanthemums six or eight inches in diameter and densely double, each petal being deeply fringed; blooms profusely. Price, per packet, 15 cents.

\section{STOCKS.}

Sometimes called Gilliflowers. These popular flowers are easily grown and are so highly fragrant and of such great beauty, and have so many good qualities, that they deserve alace in every carden. They should be given cood, rich soil to grow in and will reward good treatment with re markable pyramids of bloom.

PERPETUAL WHITE. (Princess Alice or Cut no Come Again.) Strong growth; of fine branching habit, and if sown early will bloom from May to November. Flower very large and pure white; the more they are cut the bet ter they like it. Deliciously fragrant. Price, per packet. 10 cents.

PERPETUAL MIXED. A mixture of colors of the con tinuous blooming types of perpetual stocks. A splendid selection of geed from the choicest strains. Price, por packet, 10 cents.

LARGE FLOWERING DWARF GERMAN. Most popular flower with our German customers. Our mixture contains a great variety of colors. Price, per packet, 5 cents. 


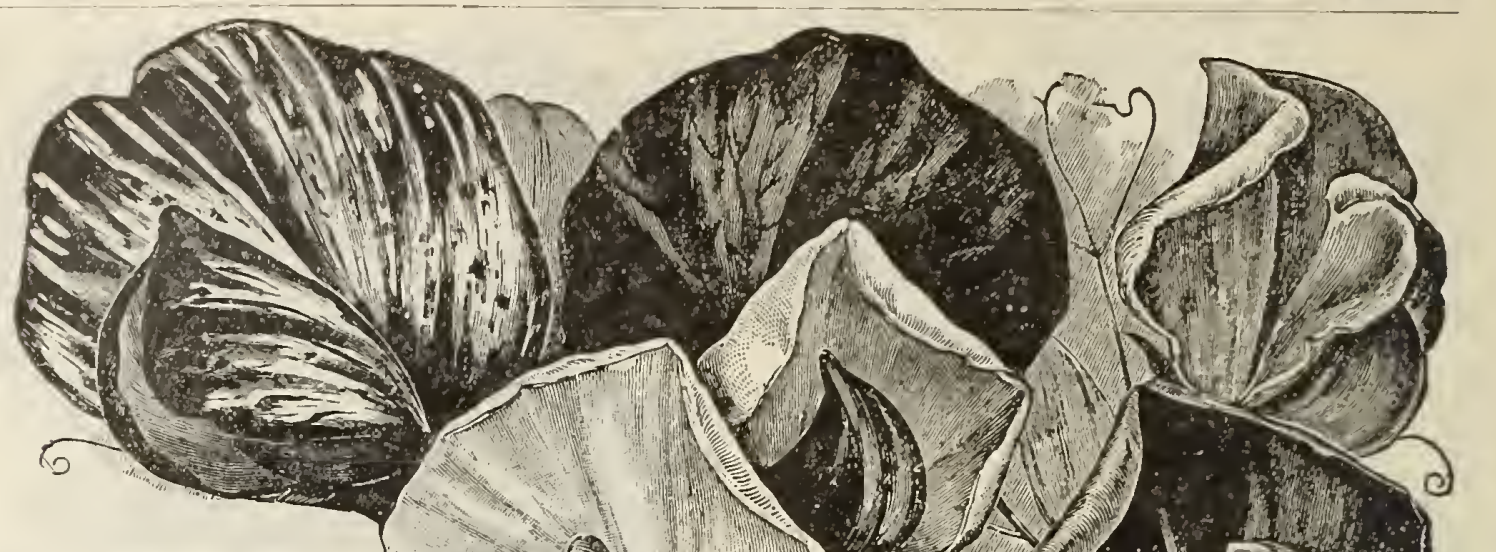

\section{OUR NEW MIXED} SWEET PEAS

This surpassing mixture includes the rery finest and most distinct varieties now in ccultivation. No strain offered will give better re sults.

\section{VESTAL'S "PRIZE" MIXTURE}

This mixture contains the ver. cream of the newest and stan. dard sorts, including all the best hew Sweet Peas in existence. It is made up entirely of separat named sorts, carefully, proportion. ed as to its composition, and we san safely say. There is no better mixture in existence." no matter at what price or under what name it may be offered. Price, per packet, 5 cents; one-half ounce, 10 cents; one ounce, 15 cents; one pound $\$ 1.50$.

\section{SELECT IIST OF IMPROVED LARGE FLOWER- ING SWEET PEAS}

We offer below a list of the hest varieties of Sweet Peas now grown. In our selection we have the clearest, most distinct shades-that stand in the sun-and do not fade quickly when cut. Get a splendid supply of new seed, as nothing can be more satisfactory. Sow seed as early in spring as grnund can he worked, so that plants get an early start. Cut blooms as fast as they apnear. which pre. vents them seeding. Seeding stops the hlooming. Price, per packet, 5 cents, seven packets for 25 cents.

DOROTHY ECKFORD. The grandest pure white yet produced, Extra large flowers, beautiful shell shape and purest white. Vines produce an enormous amount of bloom.

JANET SCOTT. This might almost he called a now shade of rich pink. The unusual size of the wings give the flower an enormous size.

SUNPROOF SALOPIAN. Finest, most brilliant scarlet, never changing colors.

KING EDWARD VII. MIost gorgeous large flowers; rich blnod-scarlet: new and unrivaled.

BLACK MICHAEL. Large flowers of the finest texture a bright shining reddish-maroon, very striking. It is a erv desirable color.

SYBIL ECKFORD. Delicate hlush pink and lemon yellow, changing to pink.

ST GEORGE. Rich salmon-nrange: very brilliant. MAID OF HONOR. Large blossoms, shaded light blue on white ground, edged purple; new.

FLORA NORTON. A heautiful rich lavender; one of the most pleasing shades; very large flower.

DAVID R. WILLIAMSON. A grand fiower of bright indigo-hlue: the wings are a lighter shade of blue, extra large fiowers.

AURORA. Extra large flowers; creamy-white, flaked with orange-salmon.

NEW ORCHID-FLOWERED SWEET PEAS

This new type of Sweet $P e a$ is quite disfinct from the old standard sorts. The flowers are enormous in size usually over two inches across, with elaborately fluted wings and standard, and very delicately tinted. Bearing four of these immense blooms to a stem which is long and strong, they are truly all that could be desired in Sweet Peas.

ORCHID-FLOWERED. MIXED. This is a mixture of all the new varieties of this type of gigantic Orchid. Fowering Sweet Peas; exquisite tints which blend harmoniously. Price, per packet, 10 cents; per ounce, 20 cents.

\section{“SUPERB SPENCER" MIXTURE}

A grand, large flower of finest form and most beautiful coloring. The flowers are not only of extremely large size, but are distinct in having the outer edges of the standard and wings beautifully crumpled or wared. The coloring is a silvery white, suffused with soft rose pink. which deepens at the outer edges. In size form and color ing, Countess Spencer is simply exquisite, beyond power of words to describe. Price, per packet, 15 cents; four packets for 50 cents.

\section{TRUE "'SPENCER' SWEET PEAS}

Price, per packet, 10 cents; per ounce, 35 cents, for anJ named Spencer Sweet Pea.

COUNTESS SPENCER. Soft rose-pink; outer edges deeper pink.

PRIMROSE SPENCER. Delicate soft yellow or prim. rose color.

OTHELLO SPENCER. The popular shade of deep maroon, very rich and unusual, immense flowers much crinkled.

HELEN LEWIS. Rich orange with shadings of crimson. WHITE SPENCER. Purest white.

BEATRICE SPENCER. Pink.

KING EDWARD SPENCER. Scarlet.

ASTA OHN. Lavender 


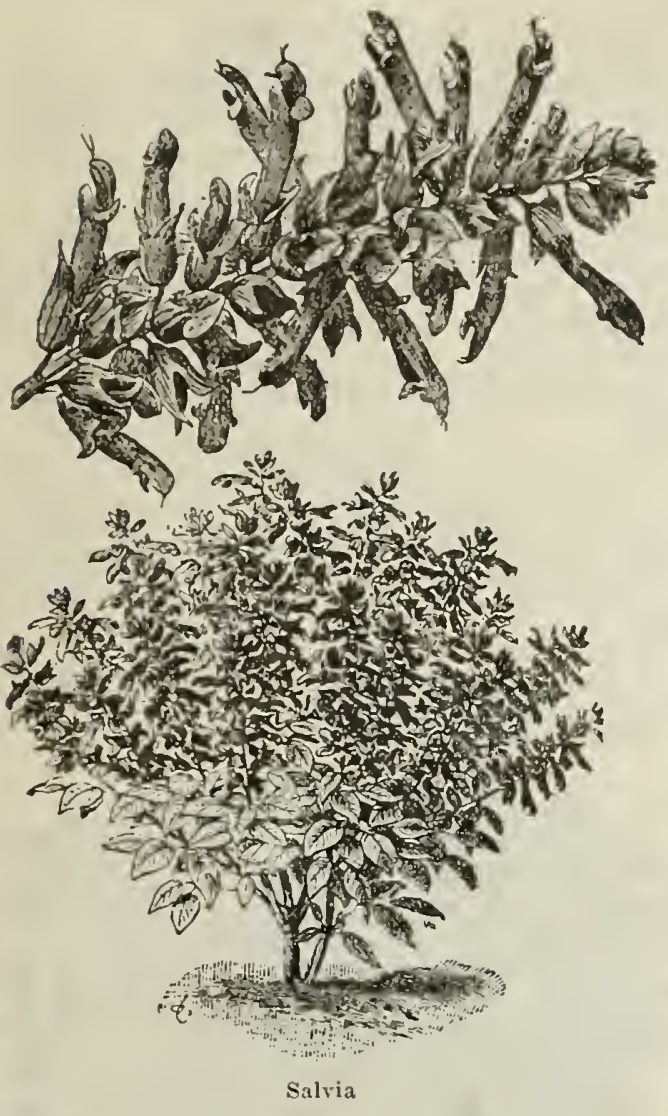

SALVIA

The Salria is now a standard bedding plant and well does it deserve its honor. Seed is best started under glass, though self-grown seed frequently comes up in great numbers where a bed of these plants had been the previous year.

SPLENDENS. Large, scarlet; exceedingly showy and useful for cutting and for ornamental beds. Price, per packet, 10 cents.

NEW SALVIA, "BALL OF FIRE", $A$ new dwarf, extra early fiowering variety. The plantitself rarely grows over a foot high, while the erect spikes of brilliant scarlet flowers average a font in length, making the total height of the plant when in full bloom between twenty and twenty-four inches by about the same in diameter. This new variety is most highly valued because it begins to bloom many weeks before the older sorts, and continues a veritable "ball of fire",
tliroughout the summer and fall. Price, per packet, 20 cents. cents.

\section{SALPIGLOSSIS}

(Velvet Flower.)

Tery showy bedding or border plants; erect, large funnel shaped flowers, The colors are beautifully marbled and penciled, purple, scarlet, crimson, yellow, buff, blue and almost black; bloom from August to October.

GRANDIFLORA, MIXED. Price, per lacket, 5 cents.

\section{SCABIOSA}

A free flowering tall annual, round full double flowers simitar to small double Dahlias. A feathery appearance. Sow early in the spring where plants are to remain.

DOUBLE MIXED. Large flowered and very double. Color's white, cherry, lilac, purple and rose. Price, per packet, 5 cents.

\section{STRAW FLOWERS Everlasting.}

The everlasting or "Straw Flowers", with their rich, bright colorings, arc most valuable for winter decorations. Plants grow readily from secd sown in the open ground when the trees are starting out in leaf.

BATCHELOR'S BUTTON. (Glole Anaranth.) Flowers are perfect globe-shaped, very double, and come in white, piuk, rose, purple and stripcd; rery good bloomers, Price, per packet, 5 cents.

HELICHRYSUM. (Straw Flower.) Showy, easily grown annuals for the border; fine for winter boquets; cut bctore the buds expand. Mixed colors. Price, per packet, 5 cents.

RHODANTHE. A lovely everlasting, either in the gar den or for winter boquets; flowers white, rose, crimson. Price, per packet, 5 cents.

\section{THUNBERGIA}

Beautiful rapid-growing climbers, thriving in a light, rich soil; in warm situations in the garden it blossoms very profusely all the season; fine for vases, rustic work, or for twining among heavy growing vines. Flowers are very bright in color coming in white cream yellow and orange with a heavily marked deep black eve. Price, per packet, 10 cents.

\section{MAMMOTH FLOWERED VERBENAS}

MAMMOTH WHITE. Flowers of unusual size, of snowy whiteness, excellent for cercetery bedding. Price, per packet, 10 cents.

MAMMOTH SCARLET DEFIANCE. A variety witl very small leaves and large heads of brilliant fiery scarlet. Price, per packet, 10 icents.

MAMMOTH COERULEA. Beautifun deep blue, very large florets marked with white eye. Price, per packet, 10 cents.

MAMMOTH PINK MIXTURE. Beautiful shades of pink, cerise and cherry, in very large heads of handsome bloom. Price, per packet, 10 cents.

MAMMOTH ITALIAN STRIPED. We offer here a mixture of the best striped Verbenas, which will come in a great variety of colors, such as white and red, white and pink, white and purple, etc. Price, per packet, 10 cents.

VESTAL'S MAMMOTH MIXTURE. This is a fine mix. ture of the mammoth flowered Verben a wich will produce heay trusses of bloom in which the individual florets are of unusual size. The colors are all that are known in the Verbena family. Price, per packet, 10 cents.

SPECIAL OFFER. One packet each of the Six Mam. moths" for 50 cents. 


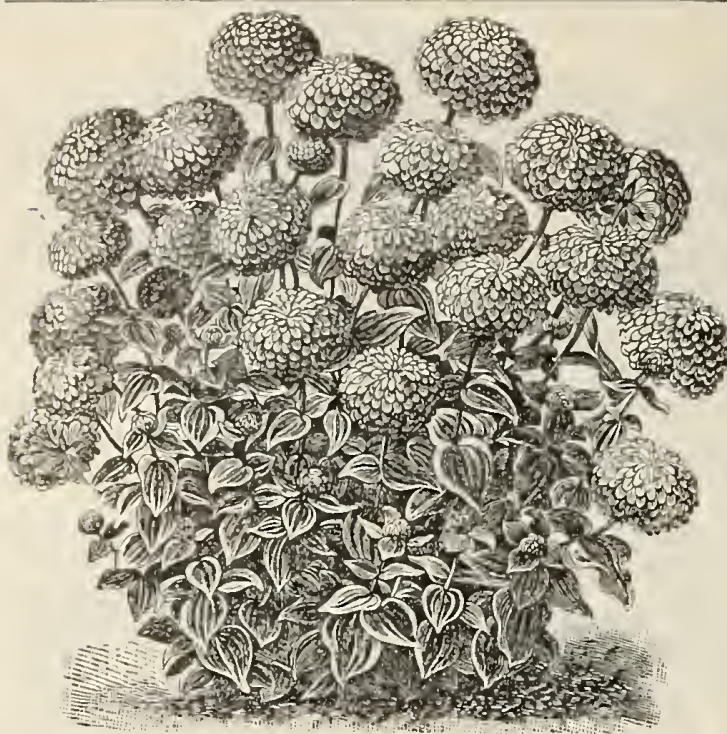

Zinnia

\section{ZINNIAS}

No flowers are more easily grown from seed in the open ground, and few bloom so continuously throughout the entire summer. Dhose acquainted only with the old-time Zinnias will be surprised at the perfection to which the newer strains have attained.

\section{MAMMOTH FLOWERED ZINNIAS}

MAMMOTH SCARLET AND GOLD. The largest anci handsomest Zinna known; flowers are pure gold, striped with vivid scarlet; very striking. Price, per packet, 10 cents.

MAMMOTH SNOW QUEEN. Very large pure white flowers, which are fine for cemetery planting. Price, per packet, 5 cents.

MAMMOTH GOLDEN QUEEN. Large flowers of pure, clear lemon-yellow. Price, per packet, 5 cents.

MAMMOTH CRIMSON JACQUIMINOT. Large Flowers of velvety texture and rich crimson shade; extra fine. Price, per packet, 10 cents.

MAMMOTH MIXTURE. A mixture of the large-flowering type, in which are the white, yellow, gold, scariet, crimson and purple. Price, per packet, 5 cents.

SPECIAL OFFER. One packet each of the Five Mam. moth Zinnias for 25 cents.

\section{OTHER TYPES OF ZINNIAS}

CRESTED AND CURLED. Curiously twisted petals, giving the flower the appearance of a small Japanese giving the flower the appearance of a small
Chrysanthemum. Price, per packet, 5 cents.

ZEBRA MIXTURE. A fine mixture of all the striped sorts; very unique and interesting. Price, per packet, 5 cents.

LILLIPUT MIXTURE. A fine class of free-flowering, Zinnias, with small, perfect flowers; fine for cutting, as they bloom most abundantly. Price, per packet, 5 cents.

BUTTON, RED-RIDING-HOOD. This little gem grows but a foot high; of compact form, and covered the entire season with little button-like, intense scarlet, very double flowers not over an inch across; as a border it is highly effective. Price, per packet, 10 cents.

SPECIAI OFFER. One each of the above four types, Orested and Curled, Zebra, Lilliput and Button, for 20

\section{WILD CUCUMBER}

A rery rapid growing climber which reaches a height of 30 feet in one season. It is covercd with beantiful clusters of white sweet-scented fiowers, followed by an abundance of ornamental prickly seed pods. Will repro. duce itself from self-sown seed every year. Price, por packet, 5 cents.

\section{WALL FLOWER}

The large, massive spikes of the Wall Flower are ver conspicuous in beds or borders, and are very useful in making boquets. They are deliciously fragrant, and com bine many shades of color-the orange, purple and choco. late predominating; tender perennial.

SINGLE MIXED. Price, per packet, 5 cents.

DOUBLE VARIETIES MIXED. Price, per packet, 10 cents.

VINCA ROSEA

(Madagascar Periwinkle.)

Ornamental free blooming plants. Seed must be sown early and then the plants will bloom the first summer. They can be taken up in the fall like Chrysanthemums, then potted and kept in bloom through winter.

ALBA. White with rose eye. Price, per packet, 10 cents.

ALBA PURA. Pure white. Price, per packet, 10 cents. ROSEA. Rose with dark eye. Price, per packet, 10 cents.

MIXED. Price, per packet, 10 cents.

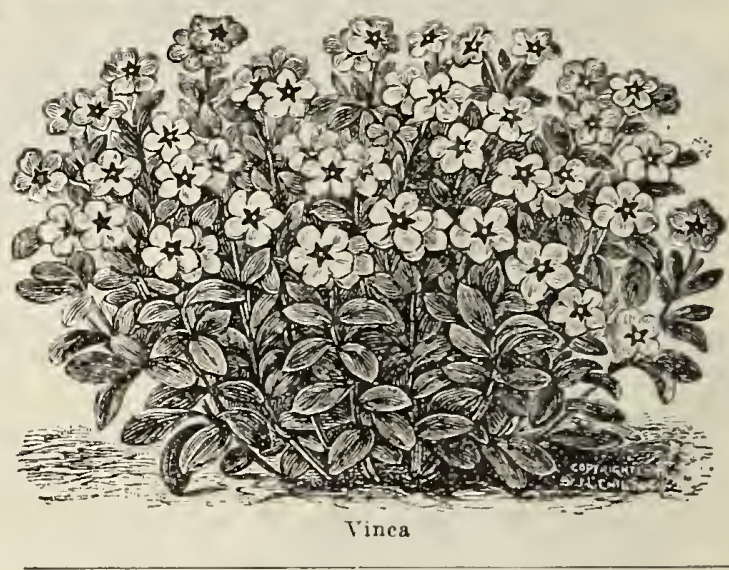

\section{QUICK GROWING VINE COLLECTION}

\section{Seven Packets for 25 cents}

ORNAMENTAL GOURDS, SMAII VARIETIES. The children's favorite. Rapid climbers, having small, brilliant colored fruit.

BALSAM APPLE. (Momordica Balsamea.) A quick growing climber, with ornamental foliage and curious yellow fruits, which, when open, are brilliant scarlet.

TRUE WHITE MOONFLOWER. The most rapid growing of all annual climbing vines. Large fragrant white flowers.

COBEA SCANDENS. A fine, rapid growing climber, with handsome, large bell-shaped flowers.

JAPANESE VARIEGATED HOP. Leaves variegated green and white.

HEAVENLY BLUE MOONFLOWERS. A rery popular vine for covering large spaces.

BALLOON VINE. (Love-in-a-Puff.) A rapid climber; seed vessels look like miniature balloons.

A SUITABLE VINE FOR EVERY PURPOSE. TRY THIS FINE, LARGE COLLECTION.

\section{SURPRISE COLLEOTION FLOWER SEED}

\section{TWENTY PACKETS FOR 50 CENTS.}

In this collection we have included all of the most popular and best flowering annuals. The seeds of each flower are of the best varieties, and will give a fine array of flowers for a little money.

SWEET PEA. A big packet. LARKSPUR. Beautiful purple. ALYSSUM. Very sweet. SCABIOSA. Mixed double. CLOVE PINKS. All shades. COSMOS. Mammoth blooms. MIGNONETTE. Sweetest scented.
MORNING GLORY. A large packet. ASTER. Largest flowering. NASTURTIUMS, Rich shades. PHLOX. Brightest colors. POPPY. Very showy. PETUNIA. Best mixed. GAILLARDLAS. All shades.
PANSY. Mammoth flowers. ZINNIAS. Giant flowered. CANDYTUFT. Every shade SWEET WILLIAM. Richest colors. CENTAUREA. Largest flowering. VERBENA. Fine flowered. 


\section{SOUTHERN STATES \\ EVERGREEN LAWN GRASS SEED}

For the convenience of those of our customers who object to the Bermuda Grass, we have decided to offer them this year

\section{SOUTHERN STATES EVERGREEN LAWN GRASS MIXTURE}

A mixture of tlie best grasses that exist for general planting in the Southern States. Most lawn grass mixtures are of little use in the South, as they burn out in dry summers. For those who have shady yards or can give the grass an abundance of water during a prolonged dry spell, we believe the Southern States Lawn Grass Mixture answers every purpose.

PRICE, 25 CENTS PER QUART. IF SENT BY MAIL, 35 CENTS PER QUART

In seeding down a lawn or grass plot, three things are necessary to insure success: First, to prepare the ground so as to have a fine, smooth seed bed; second, to put on plenty of seed-never lcss, but rather more than the directions call for; third, to start the lawn mower as soon as the weeds (which are always in the ground and sure to start first) are tall enough to catch the machine, and keep them mowed off close till the grass has time to start and become well established. The seed should be lightly raked in and finished with a roller. Fertilize when needed.

\section{QUANTITIES TO USE}

$1 \mathrm{lb}$. for 350 square $\mathrm{ft}$. 5 lbs. for 1750 square $\mathrm{ft}$. $10 \mathrm{lbs}$. for 3500 square $\mathrm{ft}$. 25 lbs. for one-fourth acre

\section{BERMUDA GRASS R00TS}

The most beautiful lawns in the South are made with Bermuda Grass Sod. It is praised from Florida to Texas. With it a grassy carpet of unrivaled emerald may be produced in six weeks time, maintaining its verdure throughout the season. There is nothing more charming than a well designed house surrounded by artistically treated grounds; and for the essential features of home grounds none is so important as a beautiful lawn-the rich, velvety green turf of the smooth, well-kept lawn being the heart and life of all.

Bermuda Grass is well suited for planting on terraces, railroad embankments and hillsides, thus preventing heavy rains from washing them out.

Bermuda Grass will withstand drought and exposure, thrive on shallow soils, and at the same time produce a rich, velvety green turf throughout the season.

This grass is not recommended for shady situations, but will thrive on the hottest and sunniest slopes. We offer clean roots of the genuine fine-leaved Bermuda Grass at the following prices. These roots mas be cut into lengths of two to three inches and planted about one inch deep, when they will start to grow and produce a thick, permanent sod in about six weeks' time.

PRICE, PER ONE-HALF BUSHEL SACK, ENOUGH FOR FIFTY SQUARE FEET, 75 CENTS; ONE BUSHEL SACK, ENOUGH FOR 100 SQUARE FEET, \$1.25; PER THREE BUSHEL BARREL, ENOUGH FOR 300 SQUART FEET, \$2.00.

\section{BERMUDA GRASS ROOTS CANNOT BE SENT BY MAIL}

When more than a bushel is wanted, we advise shipping by freight, purchasers in all cases paying transportation charges.

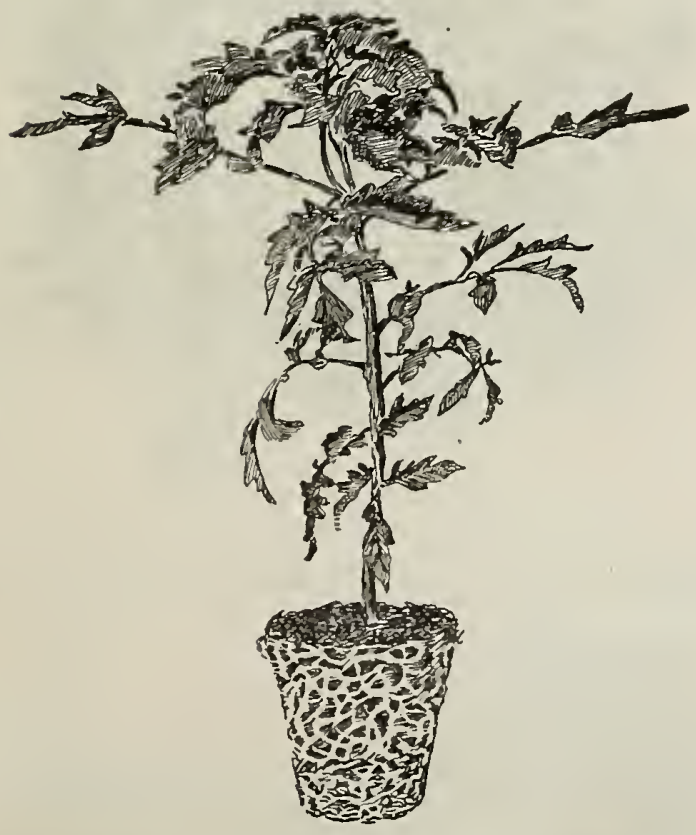

Pot Grown Tomato Plant.

\section{VEGETABLE PLANTS}

\section{CABBAGE PLANTS}

Early varieties, ready March and April. Price, 15 cents per dozen; 50 cents per $100 ; \$ 3.50$ per 1000 .

\section{EGG PLANTS}

May and June. Price, 25 cents per dozen; $\$ 2.00$ per $100 ; \$ 12.00$ per 1000 .

\section{TOMATO PLANTS}

Best named leading sorts, ready April, May and June. Price, 15 cents per dozen; 50 cents per $100 ; \$ 3.50$ per 1000 .

\section{PEPPER PLANTS}

Large Mango, ready May and June. Price, 25 cents per dozen; $\$ 2.00$ per $100 ; \$ 10.00$ per 1000 .

\section{POTTED VEGETABLE PLANTS}

To meet a demand for vegetable plants grown in pots for people who want only a few for early table use, we offer pot grown plants of the best varieties of Tomato. Pepper and Egg plant. These plants being sturdy and Pepper and Egg plant. These plants being sturdy and leave all the soil on the roots, a great advantage, as there is practically no loss in transplanting. Price, 5 cents each; 50 cents per dozen; $\$ 3.00$ per 100 . 


\section{VERANDA BOX COLLECTION}

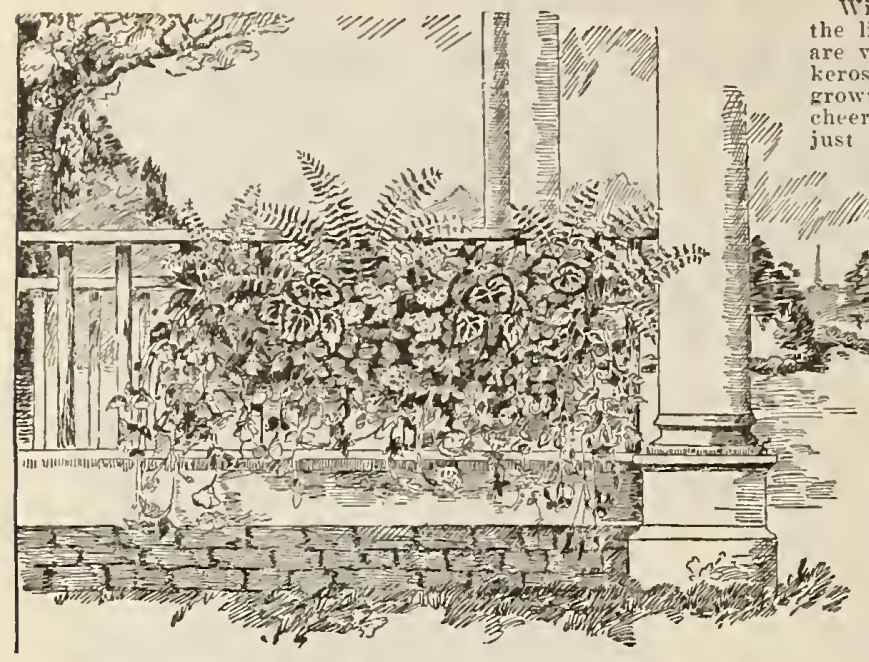

TWO GERANIUMS. The best scarlet rarieties.

ONE ABUTILON. Beautiful weeping variety.

ONE VINCA VARIEGATA. Foliage green, margined white.

ONE WEEPING LANTANA. A wonderfully profuse

ONE TRADESCANTIA.

and bronze foliage.
Window gardens hare alway been popular, but within the living room the plants contend against conditions that cerosene and coal stoves are pery injurious to purning growth. The interior window garden adds much to the cherfulness of the room, but a window or veranda box st outside of the window adds almost as much to the interior effect withont taking up the room, and adds very materially to the attractireness of the exterior. The plants grow mucl The box may be made of a great ariety of noterials, and quite atactive, bint since it is only a remale of pine will answer as well as made of pine will answer as well as
an expensive one, as the sides will on be covered up with the dronping and creeping plants. In length the loox should equal the width of the window, and eight to
twelve inches wirle by four to six inches deep with numerous holes in the bottom for drainage.

NOTE.-We have selected the following plants because they are the most satisfactory for the purpose. This collection contains enough plants for a three foot box, or an ordinary window We will supply this Veranda Box Collection of fifteen plants for 75 cents, or we will supply two collections, enough for a six foot box, or a large or twin window, for $\$ 1.25$

TWO BEGONIAS. Brilliant flowers; handsome foliage. ONE RUSSELIA. Fine grass like foliage and small

ONE PARLOR IVY. Climbing habit; rellow flowers,

ONE ACALYPHA. Beautiful ornamental foliage.

ONE NEPETA VARIEGATA. Trailing growth; leaves ONE PILEA. Fine moss like foliage: small flowers.

\section{HANGING BASKET COLLECTION OF PLANTS}

The basket may rary nuch in size and form: and in kind almost as much as the plants. Avoid a small ressel, and gire good drainage. Those most extensively used, or other forms, and lined with moss before filling and planting. The most satisfactory article we have ever used is an ordinary nail $\mathrm{keg}$, having both heads in; cut off two or three staves near the end and remore; bore sereral one and one-half inch holes in the ends and sides
in which plants can be inserted when filling and planting. We have selected the following varieties as being the most satisfactory for the purpose mentioned. They are plants of widely different growth; being of upright, climb. ing and trailing habits. We know they will give satisfaction. Should our stock of any of them become exhausted. "e reserve the right to send you others of cqual rasue. we will furnish you five choice plants, our selection, for 30 cents.

ASPARAGUS SPRENGERII. Trailing habit.

CUPHEA. Pretty; dwarf habit; brilliant flower

GERMAN IVY. Rapid grower, drooping habit. Flower's RUSSELLIA. Fine slender drooping foliage.

NEPETA VARIEGATA. Foliage green, margined white. VERNON BEGONIA. Always in bloom. Flowers green, turning bronze red in the sun.

MANETTIA VINE. Prettiest little climber.

PARROT'S FEATHER. Lovely drooping plant.

SWORD FERN. Fine louse basket plant.

WANDERING JEW. Drooping; foliage green and bronze.

HOW TO PLANT. The soil should be such as you can find in any good garden, with a liberal supply of thor. oughly rotted manure added. A common mistake in ar rnnging the plants in a hanging basket is that of erowding, and filling too full. Fewer plants will appear more grace. ful, and growth will be more vigorous if not crowded. well established and the plants the roots have become an occasional watering with weak liquid manurc will be

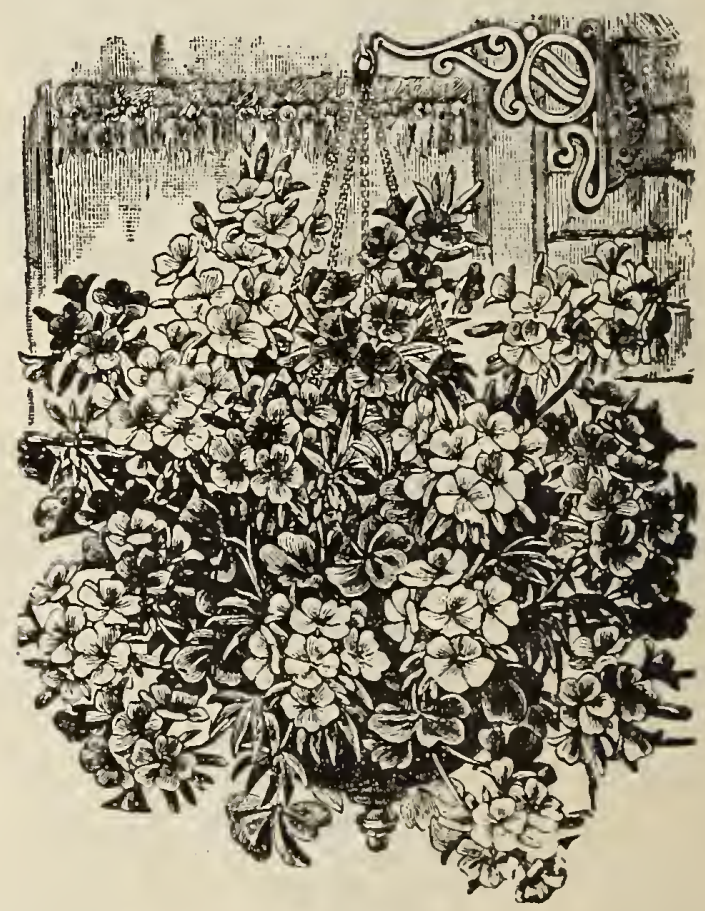

BEDDING PLANTS These plants are used for ornamental beds of foliage and flowers. We grow immense quantities charges. Selection of and are in a position to execute the largest orders. Sent by express only, purcha:er to pay iety may be ordered at the hundred rate.

AGERATUMS, Best white and blue.........................\$3.50

ALTERNANTHEAS. Yellow and red foliage............ 3.00

ACHRYANTHUS. Yellow and red foliage............... 3.00

COLEUS.

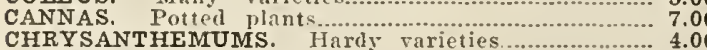

DAHLIAS. All C................ 4.00

DUSTY MILLER.

GERANIUMS. Double and single ................................. 4.00

HELIOTROPE. Purple and white

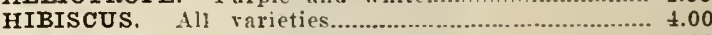

LANTANAS. Bush Verbenas.................................... 4.00

SALVIA SCARLET. …..................................... 3.50

PANSIES,

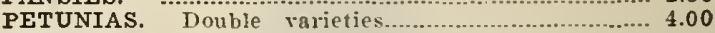

PETUNIAS. Single rarieties. ….................................. 3.00

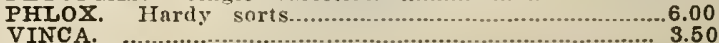

2.50 VERBENAS. All splendicl hinds................................. 3.50 


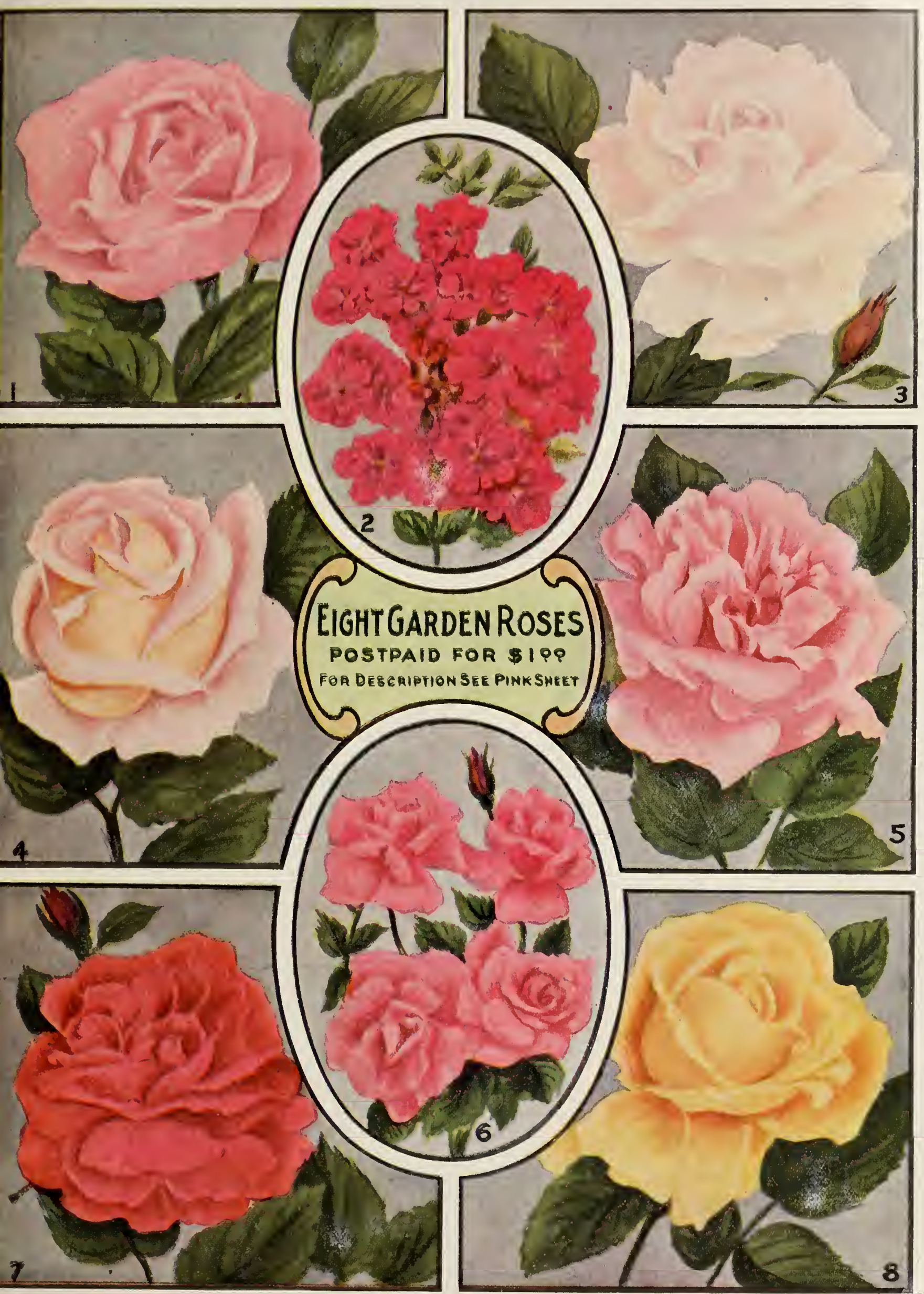




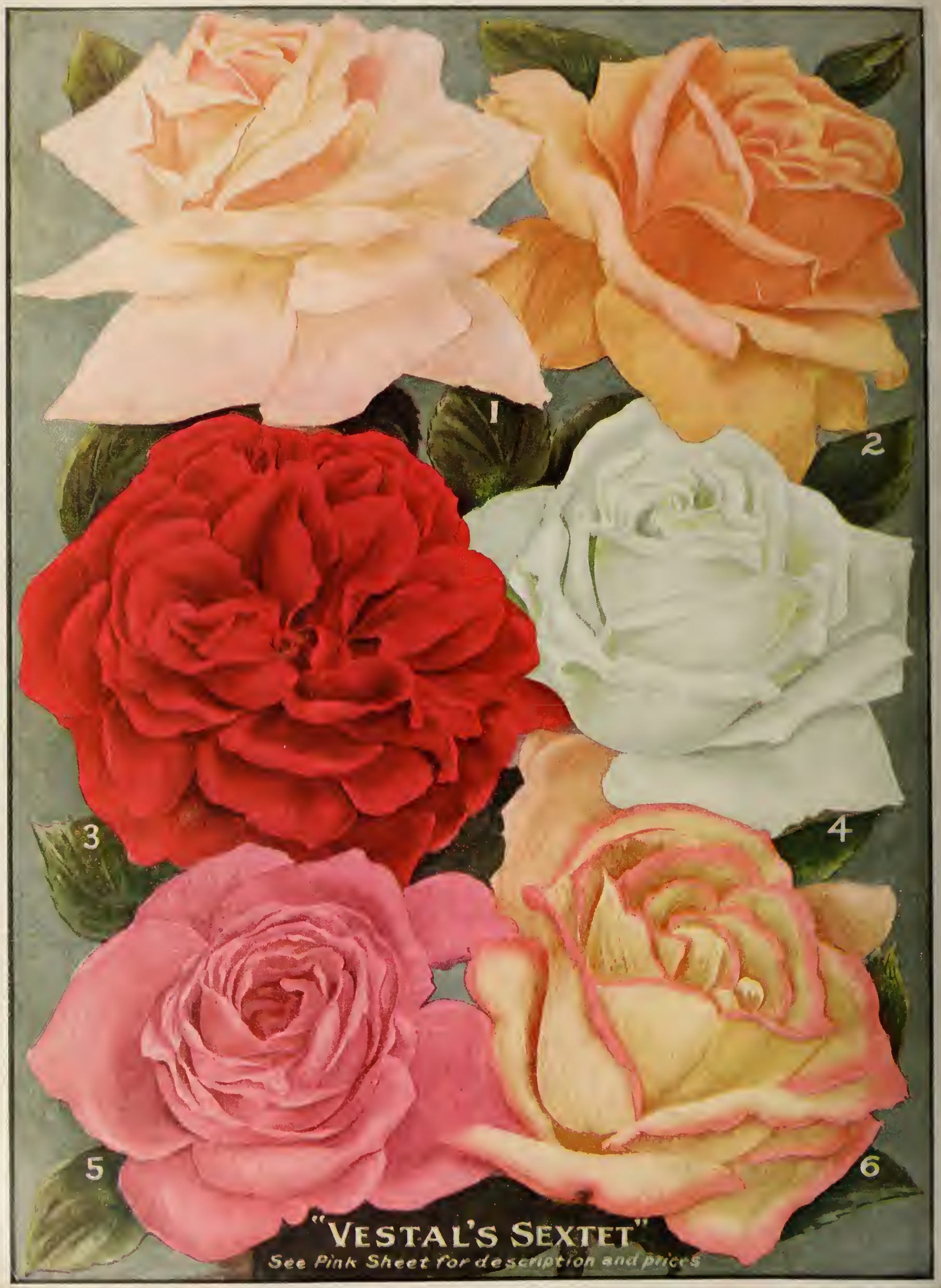

